\author{
UNIVERSIDADE DE SÃO PAULO \\ INSTITUTO DE ENERGIA E AMBIENTE \\ PROGRAMA DE PÓS-GRADUAÇÃO EM ENERGIA
}

LAÍS ALVES SOUZA

ANÁLISE DAS CONDIÇÕES PARA USO DA RECUPERAÇÃO DE ENERGIA A PARTIR DE EFLUENTES DOMÉSTICOS NO ESTADO DO MARANHÃO

São Paulo 
LAÍS ALVES SOUZA

\section{ANÁLISE DAS CONDIÇÕES PARA USO DA RECUPERAÇÃO DE ENERGIA A PARTIR DE EFLUENTES DOMÉSTICOS NO ESTADO DO MARANHÃO}

Dissertação apresentada ao Programa de Pós Graduação em Energia do Instituto de Energia e Ambiente da Universidade de São Paulo para a obtenção do título de Mestre em Ciências.

Área de Concentração: Energia

Orientador: Prof. Dr. Ildo Luís Sauer

Versão Corrigida

São Paulo 
AUTORIZO A REPRODUÇÃO E DIVULGAÇÃO TOTAL OU PARCIAL DESTE TRABALHO, POR QUALQUER MEIO CONVENCIONAL OU ELETRÔNICO, PARA FINS DE ESTUDO E PESQUISA, DESDE QUE CITADA A FONTE.

FICHA

CATALOGRÁFICA

Souza, Laís Alves.

Análise das condições para uso da recuperação de energia a partir de efluentes domésticos no Estado do Maranhão. /Laís Alves Souza; orientador: Ildo Luís Sauer. - São Paulo, 2020.

$168 \mathrm{f} .:$ il; $30 \mathrm{~cm}$.

Dissertação (Mestrado em Ciências) - Programa de PósGraduação em Energia - Instituto de Energia e Ambiente da Universidade de São Paulo.

1. Biogás. 2. Energia - recuperação. 3. Efluente doméstico Maranhão. I. Título.

Elaborado por Maria Penha da Silva Oliveira CRB-8/6961 
Nome: SOUZA, Laís Alves

Título: Análise das condições para o uso da recuperação de energia a partir de efluentes domésticos no Estado do Maranhão

Dissertação apresentada ao Instituto de Energia e Ambiente da Universidade de São Paulo para obtenção do título de Mestre em Ciências.

Aprovado em: 08/12/2020

\section{Banca Examinadora}

Prof. Dr. Ildo Luís Sauer

Instituição: Instituto de Enegia e Ambiente (IEE/USP)

Julgamento: Aprovada

Profa. Dra. Suani Teixeira Coelho

Instituição: Instituto de Enegia e Ambiente (IEE/USP)

Julgamento: Aprovada

Prof. Dr. Marcos Aurélio V. Freitas

Instituição: COPPE/UFRJ

Julgamento: Aprovada

Dra. Leidiane Ferronato Mariani

Instituição: RedBioLAC

Julgamento: Aprovada 


\section{DEDICATÓRIA}

Dedico este trabalho para todos aqueles que acreditam que podem contribuir de alguma maneira para melhorar o mundo físico que vivemos. Aqueles que acreditam que podem ser a mudança que desejam ver no mundo.

Dedico aos pesquisadores que dedicam seu tempo e esforço a entender e desenvolver soluções para a melhoria da qualidade de vida de todos, apesar de todas as dificuldades que são impostas no Brasil, neste período, de crise sanitária e política. Aqueles que conseguem ser visionários e enxergar a longo prazo, e principalmente, àqueles que conseguem tornar a academia um local de colaboração e evolução, buscando as sinergias para a melhoria da vida de todos e todas.

Dedico aos pesquisadores que enxergam o futuro do biogás como uma das soluções, e que irão auxiliar a tornar o modo de viver mais sustentável.

Dedico a todos os trabalhadores e trabalhadoras que se dedicam diariamente na manutenção e operação de sistas de água e esgoto, e que foram muito solícitos na coleta de dados para este trabalho, e que são muito dedicados para não faltar a prestação de serviço.

Dedico, enfim, aqueles que acreditaram que este trabalho seja uma contribuição para a sociedade, tanto em todo seu processo de construção, como em seu produto final. 


\section{AGRADECIMENTOS}

Agradeço a energia que nos move diariamente e nos instiga a sermos melhores e a nos desafiar. Agradeço infinitamente a minha família, meu pai, mãe e irmão, que são minha base, meu apoio, minha fonte de inspiração e motivação, meu amor e razão de viver. Além dos amigos, seja no Maranhão ou aqueles espalhados pelo Brasil e pelo mundo, que foram e são fundamentais em toda essa construção da minha vida e deste trabalho. Agradeço também à minha madrinha que contribuiu com importantes pontos de reflexão e melhoria do trabalho.

Agradeço especialmente à Profa. Sonia, Prof. Alessandro, Prof. Ronan, Prof. Theo, Camila, Samantha, Julia, Alice e Nil que me deram suporte direto com importantes pontos de melhoria da dissertação e dos experimentos, assim como em toda a experiência como mestranda, na redação de artigos e participação de congressos.

Agradeço ao Professor Ildo Sauer, por ser meu orientador e contribuir para essa etapa da minha vida.

Agradeço à CAPES que pode me fornecer uma bolsa durante certo período do Mestrado.

Agradeço à Leidiane, Melinda, e outros profissionais, que não conheço pessoalmente e que apesar das relevantes demandas do dia a dia, puderam dedicar sua atenção para contribuir na construção deste trabalho.

Agradeço ao Vetor Brasil pela oportunidade de estar atuando na Gestão Pública brasileira e possibilitar entender a importância de políticas públicas bem estruturadas e planejadas. Agradeço também à CAEMA, com todos seus colaboradores que me proporcionam muito aprendizado no dia a dia, e por ter possibilitado a execução desse trabalho também. Agradeço a todo seu corpo de funcionários que me receberam muito bem e prontamente ajudaram na coleta das informações por mais dificultoso que fosse, pois sabiam da importância disto para o meu trabalho, como para o deles.

Agradeço e parabenizo o trabalho dos operadores de sistemas de abastecimento de água e esgotamento sanitário no Estado do Maranhão e no Brasil, que se dedicam diariamente, sem final de semana e feriado para disponibilizar o serviço para a população.

Agradeço a todos e todas que não tinham nenhuma obrigação de auxiliar no desenvolvimento desta pesquisa, mas estiveram ao lado dando sugestões, apoio e contribuindo diretamente. Este trabalho também é de todos vocês.

Agradeço à Deus por esta experiência e aprendizado. 


\section{REGISTRO DE APOIO}

A autora gostaria de agradecer ao apoio da Companhia de Saneamento Ambiental do Maranhão (CAEMA) no fornecimento de informações e o apoio financeiro recebido do Instituto de Energia e Meio Ambiente da Universidade de São Paulo (IEE-USP) e da Enel Distribuição São Paulo, em parceria com a Agência Nacional de Energia Elétrica (ANEEL), por meio do Projeto de Eficiência Energética (EE) Prioritário e P\&D Estratégico intitulado "Eficiência Energética e Minigeração em Instituições Universitárias Públicas”, processo número 00390-1086 / 2018. 
"Toda grande caminhada começa com um simples passo" 


\section{RESUMO}

Frente ao cenário deficitário de coleta e tratamento de efluentes domésticos no Brasil, observase a necessidade de expandir estes serviços, de forma a melhorar a situação de saúde pública e qualidade do meio ambiente. Dentre as alternativas de incentivo para a expansão, encontramse as tecnologias para a recuperação energética dos efluentes, as quais agregam valor a este material com geração de energia renovável. Desta forma, o estudo buscou analisar as oportunidades e dificuldades para a utilização de tecnologias de recuperação energética a partir dos efluentes domésticos. Contudo, conforme apresentado na revisão sistemática de literatura, são diversas opções de tecnologias disponíveis, mas que devem ser analisadas pela viabilidade da recuperação energética, relacionada a aspectos técnicos, econômicos, sociais, ambientais e territoriais. De forma a aproximar a pesquisa da realidade, o Estado do Maranhão foi utilizado como estudo de caso. Diversos dados oficiais e públicos foram compilados e comparados com o levantamento por município, identificando que dos 217 municípios, 197 não possuem solução coletiva para esgotamento sanitário e que existe uma defasagem nas informações disponíveis. Com base nos dados, os municípios foram divididos em grupos, por similaridade, para amostragem e análises laboratoriais, as quais permitiram calcular o potencial de geração de biogás utilizando Theoretical Methane Potential (TMP) e realizar experimentos para determinar o Biogas Methane Potential (BMP). Todos as análises de potencial indicam dificuldades na geração de biogás nos municípios do Estado. Observou-se que para valores de Carbono a partir de 19\%, existe produção de biogás, como no caso de São Luís e Codó. Contudo, o mesmo não foi identificado nos experimentos, devido provavelmente ao baixo limite de detecção ou baixa quantidade de amostra. Levando em consideração o material compilado pelo Método Misto de Pesquisa, observa-se que o Maranhão apresenta um pequeno grupo de municípios (seis) mais propensos para a adoção das tecnologias de recuperação energética, cenário que pode melhorar com a concentração maior de sólidos no efluente. $\mathrm{O}$ tamanho da população, a concentração do efluente, a infraestrutura existente e a disponibilidade de investimentos indicam ser os principais aspectos que influenciam este cenário. Os outros dois grupos, que somam 211 municípios tem a opção de utilizar soluções envolvendo reatores de pequena escala e codigestão com resíduos sólidos para geração de biogás, por exemplo. Estudos mais aprofundados com coletas de esgoto doméstio durante vários meses do ano, assim como dados mais confiáveis sobre as ETEs existentes, sobre a situação dos municípios e a criação de um indicador para mensurar a viabilidade do uso da recuperação energética são importantes avanços para a adoção destas soluções no Estado do Maranhão e no Brasil.

Palavras-chave: Efluente doméstico, Recuperação Energética, Biogás, Maranhão. 


\begin{abstract}
In view of the deficient scenario of collection and treatment of domestic effluents in Brazil, there is a need to expand these services in order to improve the situation of public health and quality of the environment. Among the incentive alternatives for expansion, there are technologies for energy recovery from effluents, which add value to this material with the generation of renewable energy. In this way, the study sought to analyze the opportunities and difficulties for the use of energy recovery technologies from domestic effluents. However, as presented in the systematic literature review, there are several options of technologies available, but they must be analyzed for the feasibility of energy recovery, related to technical, economic, social, environmental and territorial aspects. In order to bring the study closer to reality, the State of Maranhão was used as a case study. Several official and public data were assembled and compared with the survey by municipality, identifying that 197 from the 217 municipalities, do not have a collective solution to sanitation and that there is a gap in the available information. Based on the data collected, the municipalities were divided into groups, by similarity, for sampling and laboratory analysis, which allowed the calculation of the biogas generation potential using Theoretical Methane Potential (TMP) and carrying out experiments to determine the Biogas Methane Potential (BMP). All potential analyzes indicate difficulties in the generation of biogas in the state's municipalities. It was observed that for carbon values above $19 \%$, there is biogas production potential, as in the case of São Luís and Codó. However, the same was not identified in the experiments, probably due to the low limit of detection or low amount of sample. Taking into account the material compiled by the Mixed Research Method, it is observed that Maranhão has a small group of municipalities (six) more likely to adopt energy recovery technologies, a scenario that may improve with the higher concentration of solids in the effluent. The size of the population, the concentration of the effluent, the existing infrastructure and the availability of investments indicate might be the main aspects that influence this scenario. The other two groups, which add up to 211 municipalities, have the option of using solutions involving small-scale reactors and codigestion with solid waste to generate biogas, for example. Further studies with collections during many months of the year, as well as more information about WWTP, also reliable data on sanitation from each municipality and the creation of an indicator to measure the feasibility of using energy recovery are important for the advancement of research and for the adoption of these solutions in the State of Maranhão and Brazil.
\end{abstract}

Keywords: domestic effluent, energy recovery, biogas, Maranhão. 


\section{LISTA DE ABREVIAÇÕES E SIGLAS}

ABETRE - Associação Brasileira de Empresas de Tratamento de Resíduos e Efluentes ABES - Associação Brasileira de Engenharia Sanitária e Ambiental ABLP - Associação Brasileira de Resíduos Sólidos e Limpeza Pública ABRELPE - Associação Brasileira de Empresas de Limpeza Pública e Resíduos Especiais ACV - Análise de Ciclo de Vida

AESBE - Associação Brasileira das Empresas Estaduais de Saneamento ANA - Agência Nacional de Águas

ANEEL - Agência Nacional de Energia Elétrica

APHA - American Public Health Association

BRAnM - Biorreator Anaeróbio de Membrana

BMP - Biogas Methane Potential

CAEMA - Companhia de Saneamento Ambiental do Maranhão

CIBiogas - Centro Internacional de Energias Renováveis-Biogás

CONAMA - Conselho Nacional de Meio Ambiente

DBO - Demanda Bioquímica de Oxigênio

DQO - Demanda Química de Oxigênio

ETE - Estação de Tratamento de Esgoto

GEE - Gases de Efeito Estufa

GNV - Gás Natural Veicular

IDH - Índice de Desenvolvimento Humano

NBR - Norma Brasileira

PLANSAB - Plano Nacional de Saneamento Básico

RAFA - Reator Anaeróbio de Fluxo Ascendente

UASB - Upflow Anaeronic Sludge Blanket

SAAE - Sistema Autônomo de Água e Esgoto

SIN - Sistema Interligado Nacional

SNIS - Sistema Nacional de Informações sobre Saneamento

SWOT - Strengths Weaknesses Opportunities e Threats

TMP - Theoretical Methane Potential 


\section{LISTA DE FIGURAS}

Figura 1 - Esquema da seleção de artigos pela metologia de revisão sistemática da literatura. 15

Figura 2 - Divisão dos artigos selecionados por país 16

Figura 3 - ETEs com recuperação energética no Brasil. 22

Figura 4 - Categorias dos tipos de potencial em relação à geração de energia ao longo do tempo. 36

Figura 5 - Diagrama de entrevistas utilizando Snowball sampling. 45

Figura 6 - Distribuição da operação de sistemas de abastecimento de água no Estado do Maranhão pelo número de municípios. 50

Figura 7 - Distribuição da operação de sistemas de esgotamento no Estado do Maranhão pelo número de municípios. 50

Figura 8. Distribuição das ETEs no Maranhão. 60

Figura 9 - Quantidade de soluções de tratamento de esgoto por tipo de tecnologia. 60

Figura 10 - Distribuição dos municípios de realização da coleta de amostras. 65

Figura 11 - Esquema representativo da coleta e análise das amostras dos ensaios. 70

Figura 12 - Montagem do sistema para Determinação do Potencial Metanogênico. 71

Figura 13 - Modelo aferidor de pressão/ vazão ETE Vinhais, São Luís. 72

Figura 14 - Imagem de satélite da ETE Vinhais com localização dos reatores e do flare. 72 


\section{LISTA DE TABELAS}

Tabela 1 - Resumo dos métodos de coleta e análise das informações da pesquisa.................... 8

Tabela 2 - Conceitos e definições utilizados no estudo. ....................................................... 10

Tabela 3 - Definição do porte das plantas de biogás.................................................................. 20

Tabela 4 - Classificação por aplicação energética do biogás das plantas em operação no Brasil

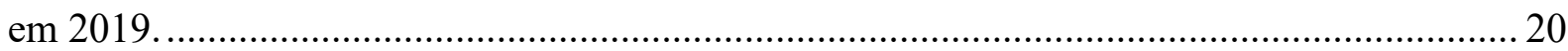

Tabela 5 - Plantas de produção de biogás no Brasil............................................................. 21

Tabela 6 - Usinas de biogás utilizando lodo e esgoto doméstico como substrato. .................. 23

Tabela 7 - Principais tecnologias de tratamento biológico de esgoto doméstico..................... 25

Tabela 8 - Definição do porte da ETE pela vazão afluente.................................................... 39

Tabela 9 - Caracterísiticas demográficas e sanitárias do Grupo 01....................................... 55

Tabela 10 - Caracterísiticas demográficas e sanitárias do Grupo 02. .....................................55

Tabela 11 - Caracterísiticas demográficas e sanitárias do Grupo 03 .................................... 56

Tabela 12 - Caracterísiticas demográficas e sanitárias do Grupo 04 .................................... 56

Tabela 13 - Características dos Grupos com base no valor da mediana. ................................ 57

Tabela 14 - Reagrupamento de municípios após levantamento.......................................... 57

Tabela 15 - Características dos Grupos redistribuídos com base no valor da mediana. .......... 58

Tabela 16 - Resultado do agrupamento dos municípios pela análise de cluster..................... 63

Tabela 17 - Detalhamento de informações sobre as amostras da Coleta 01............................ 64

Tabela 18 - Detalhamento de informações sobre as amostras da Coleta 02 .......................... 64

Tabela 19 - Parâmetros dos municípios selecionados para a coleta de amostra Ensaio 01.... 65

Tabela 20 - Parâmetros dos municípios selecionados para a coleta de amostra Ensaio 02 .... 66

Tabela 21 - Métodos analíticos utilizados na caracterização dos resíduos ............................. 67

Tabela 22 - Valores da quantidade de amostra nos biorreatores a partir da relação de sólidos voláteis - Ensaio 01.

Tabela 23 - Valores de quantidade de amostra nos biorreatores a partir da relação de sólidos

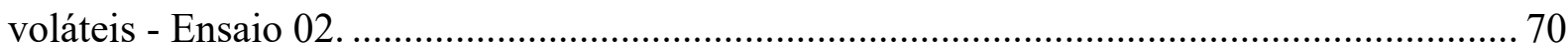

Tabela 24 - Resultados da análise laboratorial das amostras da Coleta 01 ............................ 73

Tabela 25 - Resultados da análise laboratorial das amostras da Coleta 02 ........................... 73

Tabela 26 - Produtividade téorica de biogás por município (BMP) - Ensaio 02.................... 75

Tabela 27. Produtividade téorica de biogás por município (TMP) - Coleta 02 ...................... 75

Tabela 28 - Produtividade téorica de biogás por município por dia - Coleta $02 \ldots \ldots \ldots \ldots \ldots \ldots . . . . . . .76$

Tabela 29 - Registros sobre a produção de biogás das amostras coletadas Ensaio 01............. 77 
Tabela 30 - Registros sobre a produção de biogás das amostras coletadas Ensaio 02............ 78

Tabela 31 - Valores médios obtidos nos medidores de vazão da ETE Vinhais...................... 80

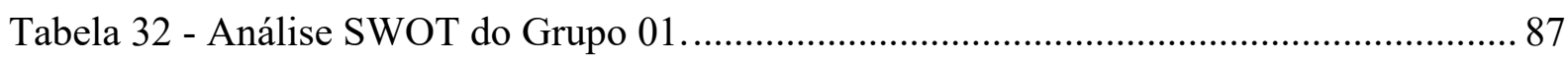

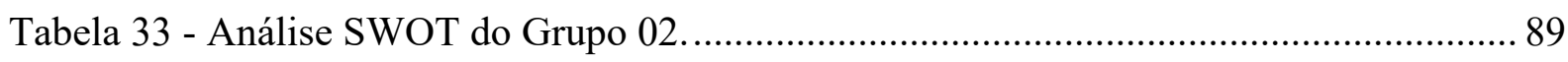

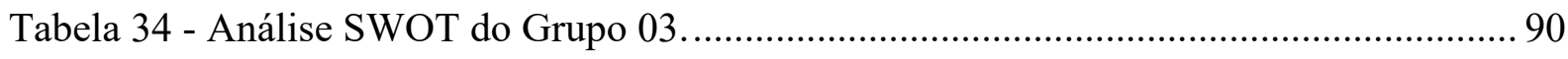

Tabela 35. Resumo de informações obtidas no estudo. .......................................................... 99 


\section{SUMÁRIO}

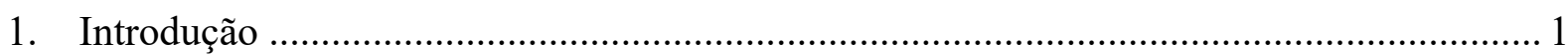

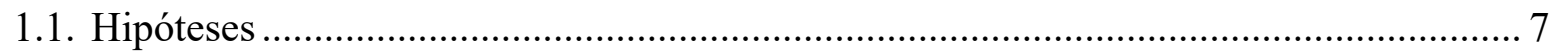

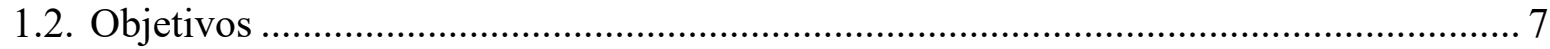

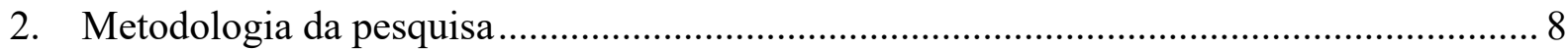

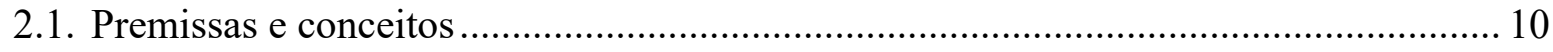

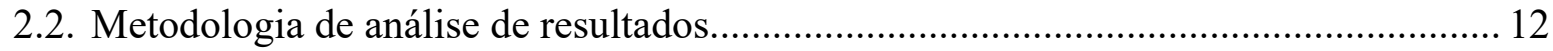

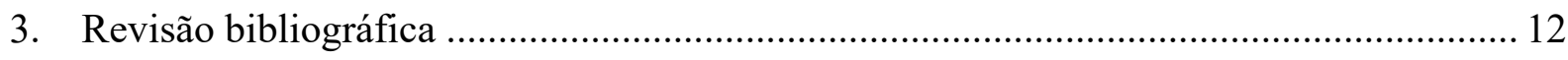

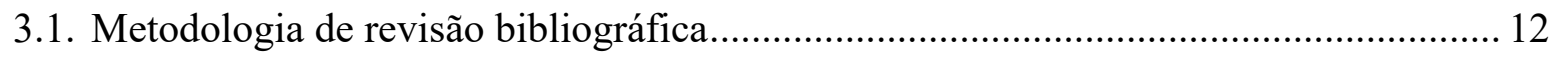

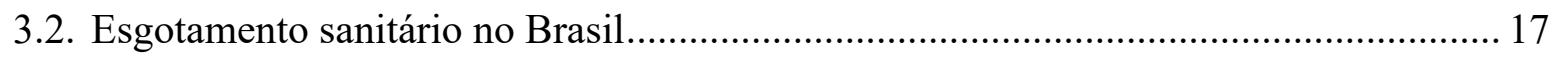

3.3. Recuperação energética a partir de esgoto doméstico no Brasil ................................ 19

3.4. Tecnologias de tratamento de esgoto e recuperação energética.................................. 25

3.5. Viabilidade do uso da recuperação energética .......................................................... 38

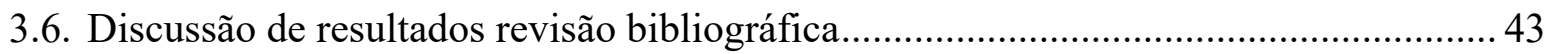

4. Estado da arte dos efluentes domésticos no Maranhão ...................................................... 44

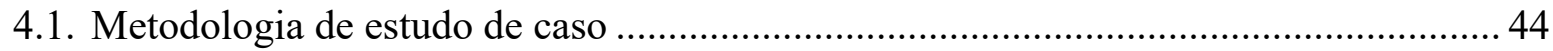

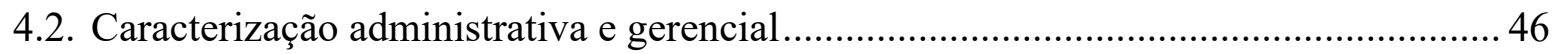

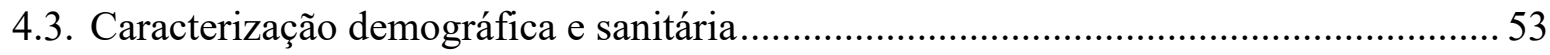

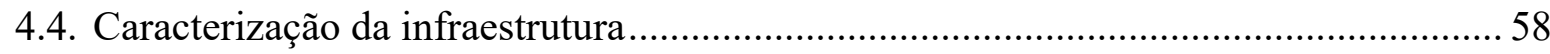

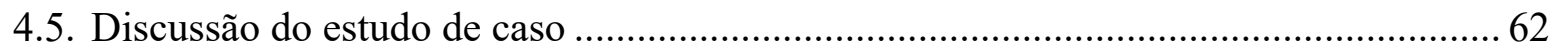

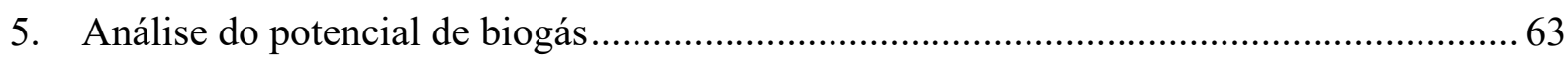

5.1. Metodologia de análise das amostras e cálculo do potencial de biogás....................... 63

5.2. Estimativa do potencial teórico de produção de biogás ........................................... 73

5.3. Estimativa do potencial empírico de produção de biogás .......................................... 77

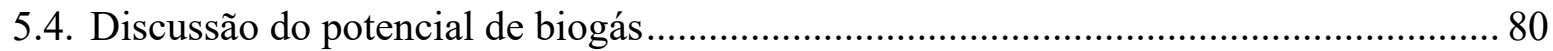

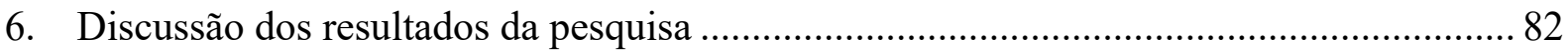


6.1. Análise das oportunidades e dificuldades 85

6.2. Análise de alternativas 93

6.3. Análise dos desafios 95

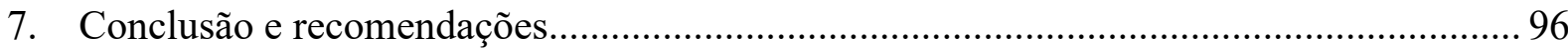

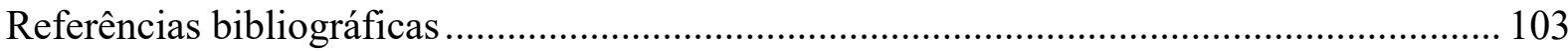

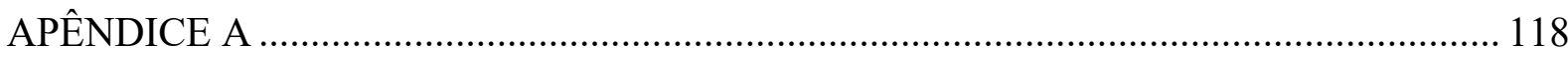

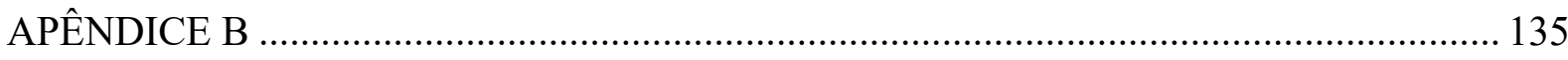

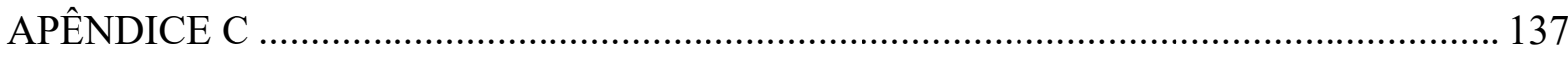

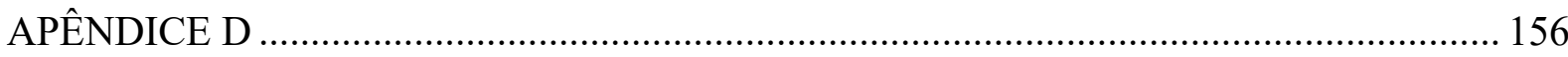

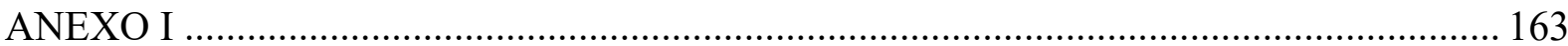




\section{Introdução}

Desde o surgimento da agricultura e a instalação de comunidades em locais fixos, a geração contínua de resíduos desencadeia a necessidade de armazenar, tratar e destiná-los de forma a não prejudicar a qualidade de vida da população. Sua destinação inadequada causa diversos problemas sanitários e de saúde pública, principalmente nos centros urbanos, onde a taxa de geração de resíduos per capita é mais elevada (ANA, 2017). A decomposição destes resíduos ocasiona a poluição do solo, água e do ar, tanto nas zonas urbanas quanto rurais. Dentre os principais tipos de resíduos urbanos gerados estão: os resíduos sólidos e os efluentes domésticos. Estes exigem formas específicas de tratamento e destinação final, sendo necessária uma análise tecnológica, econômica, social e ambiental, de forma a encontrar a solução mais adequada para cada tipo de material.

Atualmente no Brasil, aproximadamente $92 \%$ da população possui serviço de coleta de resíduos sólidos, e o montante coletado tem sido destinado para lixões, aterros controlados e aterros sanitários (ABRELPE, 2019; SNIS, 2018). No caso dos aterros sanitários, esta solução possibilita a mitigação de problemas de saúde pública, por se tratar de uma destinação ambientalmente adequada. Por outro lado, os lixões expõem a população e os recursos naturais a impactos negativos na saúde da população e na qualidade do meio ambiente, respectivamente. Por esta razão, a Política Nacional dos Resíduos Sólidos (PNRS) determinou na sua implementação, um prazo para o encerramento da disposição em lixões no país, de forma a mitigar este problema, contudo o prazo para esta regularização foi prorrogado novamente, até julho de 2021 (CNM, 2019).

No caso dos efluentes domésticos, segundo a Agência Nacional de Águas (ANA, 2017), $43 \%$ da população brasileira tem acesso a uma solução coletiva para o esgoto, com coleta e Estação de Tratamento de Esgoto (ETE) e 12\% é atendida por solução individual, com fossa séptica, por exemplo. Por outro lado, $18 \%$ da população possui coleta sem tratamento, e $27 \%$ não possui coleta nem tratamento. Logo, aproximadamente metade da população, $45 \%$, não possui a destinação adequada para o esgoto doméstico. Segundo o Sistema Nacional de Informações sobre Saneamento (SNIS, 2019), o cenário do país se mostra com aproximadamente $53 \%$ de coleta e $46 \%$ de tratamento, em relação ao montante total de esgoto gerado. Com base nestas fontes de dados da ANA e do SNIS, estima-se então, que entre $45 \%$ a $55 \%$ da população não possui destinação e tratamento adequado dos efluentes domésticos. Isto significa que das 9,1 toneladas de esgoto gerados por dia, em torno de 4,5 toneladas não tem destinação adequada, valor que equivale à geração de 2 vezes o Estado de São Paulo inteiro, ou 
95 milhões de pessoas, sem solução adequada para o esgoto. Portanto, tendo em vista que a situação do esgoto sanitário é mais precária no país em comparação aos resíduos sólidos, este será o foco deste estudo.

Considerando o panorama brasileiro, observa-se que não se trata de um problema no Brasil apenas, mas que atinge diversas populações a nível mundial (UN WATER, 2015). Por esta razão, a Organização das Nações Unidas (ONU) definiu a Agenda 2030 com 17 Objetivos do Desenvolvimento Sustentável (ODS) (ONU, 2020), em busca de um mundo que seja mais sustentável e ofereça mais bem estar à população. No caso do saneamento básico, e efluentes domésticos, estes estão representados pelos ODS 6 - Água potável e Saneamento, diretamente, contudo tangencia também o ODS 7 - Energia acessível e limpa, no caso de uso da recuperação energética de resíduos, e também o ODS 10 - Redução de desigualdades, no empenho em promover o acesso a este serviço de saneamento a toda a população, por ser direito básico na legislação.

As melhorias na situação dos efluentes domésticos, no caso do Brasil, passam por suprir a necessidade de prover os municípios com esgotamento sanitário, ou seja, atender a demanda de coleta e de tratamento do esgoto. Para isto, é necessário aumentar a abrangência do serviço de coleta, onde são necessários investimentos em infraestrutura de rede coletora, interceptores e estações elevatórias para encaminhar os efluentes para estações de tratamento. No que tange as formas de tratamento de efluentes domésticos, são necessários investimentos em Estações de Tratamento de Esgoto (ETE), com opções de tratamento aeróbio ou anaeróbio, ou pode-se optar pela solução de disposição no solo.

Esta demanda existente, tem como o retorno do investimento para o esgotamento sanitário, diretamente, os índices de saúde, e devido aos elevados custos das obras, dificuldades de executar estes investimentos e falta de priorização por parte das políticas públicas sobre o tema, o país se encontra na atual situação. Desta forma, alternativas que reduzam o custo de implantação e operação do esgotamento sanitário são atrativas para o setor. Atualmente, a integração do conhecimento sobre as tecnologias de tratamento e disposição de resíduos sólidos e sobre tecnologias de recuperação de energia a partir destes, já é estudado e utilizado em diversos aterros sanitários, por exemplo, e tem trazido benefícios com a redução de custos na operação das plantas. No entanto, esta integração ainda é incipiente para efluentes domésticos, bem como sua aplicação (KHIEWWIJIT et al., 2015) no Brasil (CIBIOGAS, 2019).

Em julho de 2020 foi aprovado o Novo Marco Regulatório do Saneamento Básico no Brasil, Lei $\mathrm{n}^{\circ} 14.026 / 2020$, legislação que deu foco à temática, e despertou discussões sobre as melhorias no setor. Dentre os principais aspectos discutidos está, principalmente, a urgência em 
elevar os indicadores de atendimento à população. As expectativas, após a aprovação da lei, são que ocorra uma aceleração na competitividade das concessionárias e melhoria do serviço. Importante destacar, que apesar de ainda não ter se refletido em mudanças nos indicadores do SNIS, a aprovação de legislações e o fortalecimento de uma regulação melhor estruturada para o setor é fator fundamental para os avanços, não apenas para o atendimento da poulação com abastecimento de água, e esgotamento sanitário, mas também para aproveitamento de subprodutos como água de reúso, o logo e a energia, para tornar o setor cada vez mais sustentável economicamente, socialmente e ambientalmente.

Segundo a Agência Nacional de Energia Elétrica (ANEEL), a Convenção-Quadro das Nações Unidas sobre a Mudança do $\mathrm{Clima}^{1}$ (UNFCCC) e o mapa do Centro Internacional de Energias Renováveis-Biogás (CIBIOGAS, 2019), existem no total 15 plantas no país, em operação e em construção, que geram energia a partir de efluente doméstico, através do biogás e do lodo de esgoto. Cumpre ressaltar também, que plantas industriais estão atuando no tratamento de seus efluentes industriais, que compõe um número significativamente maior de estações de tratamento em relação às plantas de efluentes domésticos. Neste caso, se destaca a indústria alimentícia, agroindustrial, com plantas de pequeno a médio porte, e que utilizam majoritariamente a energia térmica proveniente da recuperação energética dos substratos provenientes de cervejarias, suinocultura, entre outros (ABIOGAS, 2020).

Dentre as formas de energia gerada nas plantas de recuperação energética a partir dos efluentes domésticos, o presente estudo teve como foco a recuperação energética através da geração de biogás. E apesar do levantamento do número de 15 plantas existentes, ainda é necessária uma atualização do mapeamento, pois existem novas plantas sendo construídas anualmente que devem ser consideradas (AESBE, 2019). Este mapeamento facilita a análise sobre o uso do biogás a partir do esgotamento sanitário e otros substratos no Brasil, e seu potencial de expansão.

Com relação ao aspecto energético, o Brasil possui uma matriz energética majoritariamente não renovável, mas que quando comparada a outros países do mundo tem um percentual renovável significativo, de aproximadamente 44\% (EPE, 2019, 2020). A energia proveniente dos resíduos fica contemplada dentre os 5,9\% de Lixívia mais outras renováveis, pois ainda é incipiente no país. Ou seja, a energia térmica, elétrica e mecânica gerada a partir de resíduos ainda aparece timidamente na matriz energética brasileira.

\footnotetext{
${ }^{1}$ United Nations Framework Convention on Climate Change em inglês.
} 
No que tange a matriz de energia elétrica brasileira, os resíduos estão classificados junto à biomassa, ocupando 8,5\% do total de energia elétrica gerada. Entre 2017 e 2018 houve um aumento de aproximadamento 3\% na geração de energia elétrica a partir de recursos renováveis no país. Parte deste percentual provem das plantas de biogás, as quais vem aumentando significativamente na matriz de energia elétrica passando de 84 em 2015, para 140 em 2018, contudo este número aumenta para 521 plantas, quando considerados outros tipos de energia (CIBIOGÁS, 2020). Importante destacar também, que houve um aumento no número de plantas para autoprodução de energia elétrica, atingindo 16,8\% da matriz (EPE, 2019). As plantas de geração de energia a partir da biomassa de resíduos sólidos e efluentes domésticos, fazem parte deste percentual, e contribuem de forma significativa para o aumento do número de plantas de autoprodução, mas normalmente não são cadastradas junto aos dados de geração energia, exatamente por terem apenas geração para próprio consumo, dificultando sua contabilização e mapeamento.

Com relação ao consumo de energia, este aumenta anualmente. Somando o setor industrial, residencial e comercial, atingiu-se o percentual de $80 \%$ do total de energia elétrica consumida no país em 2018. Tendo em vista a crescente demanda de energia, bem como o aumento da geração por meio das fontes renováveis, é fundamental analisar as condições de geração de energia a partir dos efluentes domésticos, que apesar de não aparecerem de forma significativa na matriz energética e elétrica do país, apresentam potencial de aumento gradativo nos próximos anos, além de trazerem consigo benefícios importantes no setor de saneamento e consequentemente na área da saúde.

Para abordar este tema complexo e extenso, o presente estudo inicia o segundo capítulo com a explicação sobre a estrutura do trabalho, passando pelas metodologias utilizadas para compilar dados e experiências sobre o tema e para o estudo de caso, assim como sua análise. $\mathrm{O}$ terceiro capítulo apresenta a revisão bibliográfica realizada sobre o tema, no que tange o esgotamento sanitário, a recuperação energética a partir de resíduos, e as tecnologias utilizadas para tratamento e recuperação energética, além dos aspectos que interferem na viabilidade destas soluções, informações estas que dão embasamento ao estudo. O quarto capítulo trata da contextualização do cenário do esgotamento sanitário e seu potencial de geração de energia, como indutor do aumento dos índices de cobertura de saneamento e dos índices de geração de energia renovável, utilizando um estudo de caso com a situação do Estado do Maranhão. O quinto capítulo aborda a análise do potecial de geração de biogás a partir do potencial teórico e empírico, com resultados de experimentos realizados ao longo do estudo no Estado do Maranhão. A seguir, o capítulo sexto analisa o compilado geral de informações coletadas, 
apresenta os resultados obtidos por meio da pesquisa e discute estes com a literatura e com as hipóteses levantadas, principalmente no que se refere às oportunidades e dificuldades de cada contexto. E por fim o capítulo sétimo apresenta as conclusões e recomendações para estudos futuros.

\section{Justificativa}

Frente às dimensões demográficas do Brasil e seu potencial de recuperação energética a partir de efluentes domésticos com geração de biogás (CIBIOGAS, 2018), considera-se que o número de plantas existentes e em construção, é pouco significativo e se concentra, atualmente, nas regiões Sul e Sudeste. Tendo em vista a situação deficitária de coleta e tratamento de esgoto no país, principalmente nas regiões Norte e Nordeste, em conjunto com a possibilidade de recuperação energética dos efluentes domésticos, possibilitando o aumento de uma matriz mais renovável, supõe-se que a adoção destas tecnologias teria como impactos positivos, principalmente: o incentivo à ampliação da abrangência do serviço de esgotamento sanitário; a redução de problemas de saúde pública; e a geração de energia. Desta forma, o estudo tem o intuito de analisar as oportunidades e dificuldades relacionadas à recuperação de energia a partir dos efluentes domésticos em um estado brasileiro, para compreender de que maneiras podem ser tomadas decisões em busca da ampliação do esgotamento sanitário, tendo como incentivo a possibilidade do uso da recuperação energética.

Já existem estudos sobre o potencial de biogás a nível nacional, entretanto são pouco precisos e exigem generalizações significativas comparadas às análises a nível estadual ou municipal (MARIANI, 2018). No país, dentre as 27 unidades federativas, os Estados com menores Índices de Desenvolvimento Humano (IDH) são também aqueles que possuem os menores índices de cobertura e tratamento de efluentes domésticos. O Estado do Maranhão, $26^{\circ}$ Estado no Ranking de IDH (IBGE, 2010) será utilizado como estudo de caso nesta dissertação.

No Maranhão, atualmente a capital São Luís, possui aproximadamente $73 \%$ do esgoto coletado e $24 \%$ do esgoto tratado por ETEs (SNIS, 2019). Por outro lado, no restante do Estado, o tratamento por ETEs são realidade em pouco municípios como Imperatriz, São José de Ribamar, Barreirinhas e Carolina. Imperatriz é a segunda maior cidade do Estado em contingente populacional, São José de Ribamar faz parte da região metropolitana da capital, Barreirinhas possui foco turístico devido à proximidade ao Parque Nacional dos Lençóis Maranhenses e Carolina possui como foco turístico a proximidade à Chapada das Mesas. No restante dos municípios as soluções são inexistentes ou alternativas, como sistemas compactos 
em loteamentos Residenciais particulares ou do Programa Minha Casa, Minha Vida, ou soluções individuais como fossas sépticas.

Os principais motivos da escolha do Estado do Maranhão como estudo de caso são: disponibilização de dados mais detalhados da situação maranhense, considerando que a autora da dissertação trabalha na Companhia de Saneamento Ambiental do Maranhão (CAEMA), e por se tratar de um dos Estados mais pobres do país (IBGE, 2017), com baixa taxa de coleta e tratamento de esgoto, e onde se supõe que as adversidades para o uso da recuperação de energia a partir dos efluentes domésticos devam ser mais explícitas e desafiadoras.

No Maranhão, assim como no restante do país, existe uma demanda crescente de consumo de energia. Apesar da produção de energia elétrica ter sofrido uma redução de aproximadamente $3 \%$ em 2018, em relação ao ano anterior, o consumo de energia elétrica residencial no Estado passou de $1.917 \mathrm{GWh}$ em 2010 para 3.209 GWh em 2018, um aumento de aproximadamente 67\% (EPE, 2019). Desta forma, a tendência de crescimento do consumo energético em conjunto com o potencial de expansão da cobertura de esgotamento sanitário, passa pela definição das tecnologias mais adequadas para cada situação. Estas soluções permitem a oferta de melhorias na qualidade de vida da população, bem como economia de energia para o Estado.

A pesquisa apresenta os dados detalhados e atualizados da situação de coleta e tratamento de esgoto do Maranhão, e analisa os dados da estimativa do potencial de biogás produzido a partir do esgoto de alguns municípios do Estado. Com os dados adquiridos e analisados, próximos estudos poderão se embasar para reproduzir o diagnóstico e análise em outras Unidades Federativas, bem como para aprofundar os estudos no próprio Maranhão. Em se tratando de um Estado com baixos índices de desenvolvimento social e com carência de informações em diversas áreas, como a de saneamento, a apresentação destes dados garante o caráter inédito do estudo e servirá de base para próximas contribuições.

Atrelado a este direcionamento, de geração de informações com o diagnóstico, o trabalho se propõe a gerar dados sobre o esgoto sanitário no Brasil, tendo em vista que estas informações apresentam dificuldades para se obter em todo o mundo. Dentre os 181 países analisados por Sato, Qadir, Yamamoto (2013), aproximadamente 30\% possuem informações sobre geração, tratamento e destinação do esgoto sanitário, as quais podem ainda estar desatualizadas ou não serem coerentes com a realidade. A disponibilidade destas informações, atualizadas periodicamente e corretas, é de fundamental importância para a elaboração do planejamento e o desenvolvimento de políticas públicas que acompanhem o crescimento da demanda, visando mitigar problemas de saúde pública e melhorar a qualidade de vida da população (BREACH, 2018; SATO; QADIR; YAMAMOTO, 2013). 


\subsection{Hipóteses}

Com base nas informações coletadas e interpretadas, a seguir são apresentadas as principais hipóteses a serem analisadas no presente estudo:

- Supõe-se que é viável a recuperação de energia através do biogás de efluentes domésticos nos municípios do Maranhão utilizando as tecnologias existentes, contudo a viabilidade do uso da tecnologia varia de acordo com as características do município;

- No caso dos municípios que não conseguem viabilizar a recuperação energética do esgoto através do biogás, existem alternativas que utilizam o lodo de esgoto ou a codigestão e podem viabilizar a geração de energia;

- As características demográficas dos municípios, a quantidade de recursos financeiros destinada ao município e as características dos substratos são os principais aspectos que influenciam a viabilidade da recuperação energética através do biogás em cidades do Estado do Maranhão.

\subsection{Objetivos}

O objetivo geral deste trabalho é analisar as oportunidades e dificuldades para a utilização de tecnologias de recuperação de energia através do biogás a partir de efluentes domésticos no Estado do Maranhão. De forma a alcançar o objetivo principal do estudo, a pesquisa desenvolveu os seguintes objetivos específicos:

1) Analisar as principais discussões e contribuições sobre o tema, com base em revisão sistemática da literatura;

2) Diagnosticar a situação atual do esgotamento sanitário no Maranhão:

a) Caracterizar a gestão da coleta e tratamento dos efluentes domésticos no Estado do Maranhão;

b) Classificar os municípios quanto a aspectos demográficos e sanitários;

c) Mapear a infraestrutura de tratamento dos efluentes domésticos no Estado;

3) Avaliar o potencial de geração de biogás a partir de efluentes domésticos no Maranhão:

a) Analisar o potencial teórico de geração de biogás;

b) Analisar o potencial empírico de geração de biogás;

4) Analisar quais as tecnologias mais adequadas para viabilidade de sistemas de recuperação energética nos municípios do Maranhão; 
a) Analisar os grupos através do método SWOT.

b) Analisar quais são as tecnologias mais adequadas para o tratamento de efluente doméstico e sua recuperação energética por grupo;

\section{Metodologia da pesquisa}

Esta seção foi dividida de forma a esclarecer detalhadamente todos os métodos utilizados na pesquisa. Tendo em vista que a metodologia engloba a utilização de métodos quantitativos, destinados para avaliação de números, e qualitativos, destinados para a interpretação de palavras, para atender ao objetivo da pesquisa, adotou-se a abordagem do Método Misto de Pesquisa. Este tipo de abordagem permite melhor entendimento e consistência de informações englobando as diversas variáveis que compõe o estudo (JOHNSON; CHRISTENSEN, 2014). No caso desta pesquisa, dentre as cinco proposições apontadas por Greene, Caracelli, Graham (1989), escolheu-se o Método Misto de expansão do tema, sendo utilizados métodos com diferentes abordagens, que podem ser aplicados simultaneamente e com resultados que podem se complementar, para melhor compreenssão dos aspectos que compõe o objeto de estudo, bem como sua validação com diversas evidências (GREENE; CARACELLI; GRAHAM, 1989). A seguir, na Tabela 1 é apresentado o resumo dos métodos utilizados na pesquisa.

Tabela 1 - Resumo dos métodos de coleta e análise das informações da pesquisa.

\begin{tabular}{|c|c|c|c|c|c|}
\hline $\begin{array}{c}\text { Objetivo } \\
\text { de } \\
\text { Pesquisa }\end{array}$ & Abordagem & Ferramentas & $\begin{array}{c}\text { Tipo de } \\
\text { Informação }\end{array}$ & Método & Fonte de Dados \\
\hline $\begin{array}{l}\text { Premissas } \\
\text { e conceitos } \\
\text { adotados } \\
\text { no estudo }\end{array}$ & Qualitativo & $\begin{array}{c}\text { Documentos e } \\
\text { artigos científicos }\end{array}$ & Secundária & $\begin{array}{c}\text { Pesquisa em } \\
\text { artigos e } \\
\text { relatórios }\end{array}$ & $\begin{array}{c}\text { Banco de artigos, } \\
\text { estudos e relatórios } \\
\text { de instituições } \\
\text { nacionais e } \\
\text { internacionais }\end{array}$ \\
\hline $\begin{array}{l}\text { Revisão de } \\
\text { literatura }\end{array}$ & Qualitativo & Artigos científicos & Secundária & $\begin{array}{l}\text { Pesquisa em } \\
\text { arquivos }\end{array}$ & $\begin{array}{c}\text { Banco de artigos de } \\
\text { instituições } \\
\text { nacionais e } \\
\text { internacionais }\end{array}$ \\
\hline \multirow[b]{2}{*}{$\begin{array}{l}\text { Estudo de } \\
\text { caso }\end{array}$} & Quantitativo & $\begin{array}{c}\text { Base de dados e } \\
\text { documentos, } \\
\text { software de } \\
\text { georreferenciamento }\end{array}$ & $\begin{array}{l}\text { Primária/ } \\
\text { Secundária }\end{array}$ & $\begin{array}{l}\text { Pesquisa em } \\
\text { base de } \\
\text { dados e } \\
\text { relatórios }\end{array}$ & $\begin{array}{c}\text { Relatórios de } \\
\text { instituições } \\
\text { nacionais e da } \\
\text { CAEMA }\end{array}$ \\
\hline & Qualitativo & $\begin{array}{c}\text { Snowball sampling e } \\
\text { entrevistas com } \\
\text { instituições }\end{array}$ & Primária & $\begin{array}{l}\text { Questionário } \\
\text { semi } \\
\text { estruturado }\end{array}$ & $\begin{array}{l}\text { Principais atores do } \\
\text { setor de } \\
\text { saneamento de cada } \\
\text { município e/ou } \\
\text { instituição } \\
\text { vinculada }\end{array}$ \\
\hline
\end{tabular}




\begin{tabular}{cccccc}
\hline $\begin{array}{c}\text { Objetivo } \\
\text { de } \\
\text { Pesquisa }\end{array}$ & Abordagem & Ferramentas & $\begin{array}{c}\text { Tipo de } \\
\text { Informação }\end{array}$ & Método & Fonte de Dados \\
\hline $\begin{array}{c}\text { Coleta e } \\
\text { análise } \\
\text { das } \\
\text { amostras }\end{array}$ & Quantitativo & $\begin{array}{c}\text { Experimentos em } \\
\text { laboratório }\end{array}$ & Primária & $\begin{array}{c}\text { Tabulação e } \\
\text { cálculos }\end{array}$ & $\begin{array}{c}\text { Resultados das } \\
\text { amostras coletadas }\end{array}$ \\
$\begin{array}{c}\text { Análise de } \\
\text { resultados }\end{array}$ & Qualitativo & $\begin{array}{c}\text { Documento e artigos } \\
\text { científicos }\end{array}$ & $\begin{array}{c}\text { Primária/ } \\
\text { Secundária }\end{array}$ & $\begin{array}{c}\text { Análise } \\
\text { SWOT }\end{array}$ & $\begin{array}{c}\text { Banco de artigos, } \\
\text { relatórios de } \\
\text { instituições } \\
\text { nacionais e } \\
\text { internacionais, } \\
\text { resultados das }\end{array}$ \\
\hline
\end{tabular}

Fonte: Elaborado pela própria autora.

A metodologia escolhida teve o intuito de compilar e interpretar todas as informações coletadas, para então analisá-las em conjunto. Por esta razão, optou-se por iniciar com a compilação dos principais conceitos do tema, seguir com o levantamento de artigos para leitura, coletar dados para o estudo de caso e amostras para análise, e por fim, analisar todas as informações compiladas, conforme segue abaixo:

- Levantamento de premissas e conceitos adotados no estudo: compilado de conceitos utilizados na pesquisa e que a literatura apresenta certas interpretações ambíguas ou com significados variados em diferentes contextos;

- Metodologia de revisão de literatura: levantamento dos principais artigos sobre o tema para serem inseridos na revisão bibliográfica e para embasar o trabalho;

- Metodologia do estudo de caso: procedimentos para adquirir e analisar informações sobre o caso escolhido;

- Metodologia de coleta e análise das amostras: procedimentos utilizados para colher, armazenar e analisar as amostras de esgoto coletadas, para o estudo do potencial de geração de biogás;

- Metodologia de análise de resultados: procedimentos utilizados para tratar e analisar as informações coletadas na pesquisa, de maneira a cumprir com os objetivos e responder às hipóteses definidas.

A metodologia detalhada será explicada em cada capítulo, em conjunto com a apresentação dos resultados e sua discussão. Ao final da pesquisa foi realizado um compilado dos resultados e sua discussão. Por fim, a conclusão apresenta os principais aspectos extraídos destes resultados do estudo. 


\subsection{Premissas e conceitos}

Dada a variabilidade de definições para os objetos de interesse desta pesquisa, tanto no campo do saneamento ambiental, quanto no da energia, os conceitos centrais do trabalho são consolidados neste tópico. A Tabela 2 apresenta um resumo destes conceitos.

Tabela 2 - Conceitos e definições utilizados no estudo.

\begin{tabular}{|c|c|c|}
\hline Conceito & Definição & Referências \\
\hline Bioenergia & $\begin{array}{l}\text { Energia produzida a partir da biomassa (incluindo a fração } \\
\text { orgânica do resíduo municipal) e utilizado diretamente como } \\
\text { combustível ou processado em líquidos ou gases. }\end{array}$ & (WBA, 2017) \\
\hline Biogás & $\begin{array}{l}\text { Gás obtido da fermentação anaeróbia da biomassa em aterros, } \\
\text { estações de tratamento de esgoto, entre outros, gerando } \\
\text { principalmente metano e dióxido de carbono. }\end{array}$ & $\begin{array}{l}\text { (AGÊNCIA } \\
\text { NACIONAL DE } \\
\text { PETRÓLEO } \\
\text { ANP, 2017) }\end{array}$ \\
\hline Biomassa & $\begin{array}{l}\text { Qualquer tipo de material orgânico derivado de plantas, animais } \\
\text { ou algas. Considerando também material biológico proveniente } \\
\text { de Estações de Tratamento de Esgoto (ETE). }\end{array}$ & (WBA, 2017) \\
\hline \multirow{3}{*}{ Biometano } & $\begin{array}{l}\text { Resultado do processo de purificação do biogás com alto poder } \\
\text { calorifico e que pode ser utilizado em substituição do Gás } \\
\text { Natural Veicular. }\end{array}$ & $\begin{array}{l}\text { (ABIOGAS, } \\
\text { 2019) }\end{array}$ \\
\hline & \multirow[b]{2}{*}{$\begin{array}{l}\text { Gás constituído essencialmente de metano, derivado da } \\
\text { purificação do biogás, o qual tem seus parâmetros especificados } \\
\text { conforme Resolução vigente. }\end{array}$} & (AGÊNCIA \\
\hline & & $\begin{array}{l}\text { NACIONAL DE } \\
\text { PETRÓLEO } \\
\text { ANP, 2017) }\end{array}$ \\
\hline $\begin{array}{l}\text { Efluente } \\
\text { doméstico } \\
\text { ou esgoto } \\
\text { doméstico }\end{array}$ & $\begin{array}{l}\text { São sinônimos e são constituídos de despejos líquidos } \\
\text { resultantes do uso da água para higiene e necessidades } \\
\text { fisiológicas humanas, os quais podem ser provenientes de } \\
\text { domicílios, edifícios comerciais, industriais, ou qualquer imóvel } \\
\text { que contenha banheiros e cozinhas. Este material é composto por } \\
\text { substâncias das necessidades fisiológicas como urina, fezes, } \\
\text { restos de comida, lavagem de áreas comuns, etc. Sua } \\
\text { composição inclui sólidos suspensos, sólidos dissolvidos, } \\
\text { matéria orgânica, nutrientes (nitrogênio e fósforo) e organismos } \\
\text { patogênicos (vírus, bactérias, protozoários e helmintos). }\end{array}$ & $\begin{array}{c}\text { (ASSOCIAÇÃO } \\
\text { BRASILEIRA } \\
\text { NORMAS } \\
\text { TÉCNICAS - } \\
\text { ABNT, 1993) }\end{array}$ \\
\hline $\begin{array}{l}\text { Esgoto } \\
\text { sanitário }\end{array}$ & $\begin{array}{l}\text { Despejo líquido constituído de esgotos doméstico e industrial, } \\
\text { água de infiltração e a contribuição pluvial parasitária. }\end{array}$ & $\begin{array}{c}\text { (ASSOCIAÇÃO } \\
\text { BRASILEIRA } \\
\text { NORMAS } \\
\text { TÉCNICAS - } \\
\text { ABNT, 1993) }\end{array}$ \\
\hline
\end{tabular}




\begin{tabular}{|c|c|c|}
\hline Conceito & Definição & Referências \\
\hline Resíduo & $\begin{array}{l}\text { Quaisquer substâncias ou objetos de que o detentor se desfaz ou } \\
\text { tem intenção ou obrigação de se desfazer. }\end{array}$ & $\begin{array}{l}\text { (UNIÃO } \\
\text { EUROPEIA, } \\
\text { 2008) }\end{array}$ \\
\hline $\begin{array}{l}\text { Resíduo } \\
\text { orgânico }\end{array}$ & $\begin{array}{l}\text { Resíduos constituídos por restos de animais ou vegetais } \\
\text { descartados de atividades humanas. Podem ter diversas origens, } \\
\text { como doméstica ou urbana (restos de alimentos e podas), } \\
\text { agrícola ou industrial (resíduos de agroindústria alimentícia, } \\
\text { indústria madeireira, frigoríficos), de saneamento básico (lodos } \\
\text { de estações de tratamento de esgotos), entre outras. }\end{array}$ & $\begin{array}{l}\text { (PNUD; MMA, } \\
\text { 2010) }\end{array}$ \\
\hline & $\begin{array}{l}\text { Resíduos nos estados sólido e semi-sólido, que resultam de } \\
\text { atividades de origem industrial, doméstica, hospitalar, comercial, } \\
\text { agrícola, de serviços e de varrição. }\end{array}$ & $(\mathrm{ABNT}, 2004)$ \\
\hline $\begin{array}{l}\text { Resíduo } \\
\text { sólido }\end{array}$ & $\begin{array}{l}\text { Material, substância, objeto ou bem descartado resultante de } \\
\text { atividades humanas em sociedade, cuja destinação final se } \\
\text { procede, se propõe proceder ou se está obrigado a proceder, nos } \\
\text { estados sólido ou semissólido, bem como gases contidos em } \\
\text { recipientes e líquidos cujas particularidades tornem inviável o } \\
\text { seu lançamento na rede pública de esgotos ou em corpos d'água, } \\
\text { ou exijam para isso soluções técnica ou economicamente } \\
\text { inviáveis em face da melhor tecnologia disponível }\end{array}$ & (BRASIL, 2010) \\
\hline \multirow{2}{*}{$\begin{array}{l}\text { Resíduo } \\
\text { Sólido } \\
\text { Urbano } \\
\text { (RSU) }\end{array}$} & $\begin{array}{l}\text { Material, substância, objeto ou bem descartado resultante de } \\
\text { atividades humanas em sociedade. }\end{array}$ & (BRASIL, 2010) \\
\hline & $\begin{array}{c}\text { Consiste de produtos que sofrem combustão diretamente para } \\
\text { produzir calor e energia e é composto de resíduos domiciliares, } \\
\text { de hospitais e outras fontes que são coletados pela autoridade } \\
\text { local para incineração. }\end{array}$ & (WBA, 2017) \\
\hline
\end{tabular}

Fonte: Elaborado pela própria autora.

Adicionalmente, os conceitos de recuperação energética e geração de energia muitas vezes são utilizados como sinônimos. No entanto, a recuperação energética a partir dos resíduos está atrelada também ao seu tratamento ou destinação adequada, e não direcionada unicamente para a geração de energia (ABETRE, 2019; MARIANI, 2018; ROGGE; DE JAEGER, 2012). Ou seja, a energia gerada é um dos subprodutos do tratamento ou destinação do resíduo, a qual é realizada através da utilização de uma tecnologia de recuperação de energia associada a uma unidade de geração (SEMARH, 2019).

A partir de tratamento de resíduos com recuperação energética pode ser gerada energia elétrica e térmica, principalmente, além de energia mecânica e biometano para uso como Gás Natural Veicular (GNV), por exemplo (MARIANI, 2018). Desta maneira, o fato da energia recuperada do resíduo ser um subproduto, e não o produto principal do tratamento do efluente, pode dificultar a inserção destas tecnologias no mercado, pois a solução muitas 
vezes é comparada a outras formas de geração de energia, ao invés de outras soluções de tratamento ou destinação de resíduos.

\subsection{Metodologia de análise de resultados}

Após a execução das fases da pesquisa, os resultados são apresentados para cada uma delas: (i) revisão bibliográfica, (ii) estudo de caso sobre a situação do esgotamento sanitário no Maranhão; (iii) análise de potencial de geração de biogás no Maranhão. No caso dos resultados da revisão de literatura, são apresentadas as principais contribuições da academia acerca do tema da pesquisa. No estudo de caso do Maranhão, são apresentados os principais atores no cenário da situação do esgoto doméstico no Estado, além de dados das ETEs existentes e suas tecnologias, analisando as características dos municípios e sua influência na existência de Sistemas de Esgotamento Sanitário (SES). Na análise de potencial de geração de biogás, são apresentados os valores obtidos com os cálculos teóricos, ensaios de laboratório e medição dos aferidores de pressão.

Por fim, visando alcançar o objetivo do estudo, os resultados obtidos nas sessões anteriores são compilados e analisados sobre as oportunidades e dificuldades da recuperação energética a partir do esgoto doméstico no Estado, utilizando a análise SWOT. A análise SWOT é uma ferramenta para análise de cenários, a qual possibilita um levantamento e análise dos aspectos internos, como potencialidades e dificuldades, e aspectos externos, como oportunidades e ameaças da situação. Nesta ferramenta são utilizados quatro quadrantes: Strenghts (S) - Forças, Weakness (W) - Fraquezas, Opportunities $(O)$ - Oportunidades, e Threats $(T)$ - Ameaças, que quando preenchidas permitem realizar esta análise de cenário.

Desta foma, o estudo buscou compreender de maneira holística a situação atual do esgotamento doméstico no Maranhão e a possibilidade do uso da recuperação energética, considerando os detalhes intrínsecos a cada grupo, para auxiliar na sugestão das tecnologias mais adequadas.

\section{Revisão bibliográfica}

3.1. Metodologia de revisão bibliográfica 
Na elaboração da revisão bibliográfica, o método utilizado foi a revisão sistemática de literatura em conjunto com o método de pesquisa em arquivos. O método de revisão sistemática define as etapas da revisão de literatura e desta maneira, facilita a sistematização e replicação da pesquisa, pois transparece a forma como foram coletadas, organizadas, selecionadas e utilizadas parte significativa das informações que compõe este trabalho (SAMPAIO E MANCINI, 2007). Por outro lado, o método de pesquisa em arquivos, como desenvolvido por Sanches-Pereira et al. (2016), define a forma como são selecionadas as referências bibliográficas.

De acordo com Okoli e Schabram (2010), a revisão sistemática dispõe das seguintes etapas:

1. Estabelecimento do propósito da revisão de literatura;

2. Realização de um protocolo da revisão e treinamento da consistência da literatura;

3. Identificação da literatura;

4. Escolha dos artigos considerados na literatura a partir do resumo;

5. Avaliação da qualidade dos artigos, especificando os critérios de eliminação de artigos por este fator;

6. Extração dos dados através da elaboração de uma planilha com as principais informações dos artigos selecionados e analisados;

7. Análise dos artigos selecionados;

8. Revisão da literatura e sistematização dos resultados da pesquisa.

O intuito da revisão de literatura foi de adquirir conhecimento de colaborações anteriores e identificar o progresso nesta área de pesquisa, para fundamentar a análise sobre as oportunidades e desafios, bem como, a viabilidade da utilização de tecnologias de recuperação de energia a partir de efluentes domésticos. Entre a etapa 2 a 6 da revisão, foi utilizado o método de pesquisa em artigos. Com o objetivo definido, foram selecionadas as principais bases de pesquisa, que são ScienceDirect e Web of Science. Ambas são bases conceituadas e que possibilitam o acesso a uma vasta quantidade de revistas, livros e artigos científicos.

Os termos utilizados para a busca de artigos e capítulos de livros foram: recuperação energética (energy recovery) e tratamento de efluentes (wastewater treatment), utilizando o conector "AND", assim como, as palavras chaves wastewater treatment e energy recovery, na plataforam do ScienceDirect. No caso do Web of Science foram pesquisados os termos wastewater treatment e energy recovery no título da literatura pesquisada. O período definido para o levantamento de literatura foi 2008 a 2019 tanto na plataforma do ScienceDirect como na Web of Science. 
A primeira amostra resultou em 606 itens, dentre artigos e capítulos de livros, no ScienceDirect e 47 artigos na Web of Science. Dentre os 653 trabalhos encontrados, foram selecionados aqueles das revistas melhores ranqueadas no indicador SJR. Esta é uma medida da influência científica de periódicos acadêmicos, a qual considera o número de citações do periódico e sua importância frente a outros periódicos. Com o intuito de viabilizar a leitura completa dos artigos com maior número de citações, foi utilizado o ranking do indicador SJR, onde selecionou-se as revistas melhor ranqueadas para o tema do trabalho, quais sejam: Water Research, Bioresource Technology, Applied Energy, Science of the Total Environment, Energy Conversion and Management e Journal of the Environmental Management. A partir desta seleção, no total restaram 219 artigos.

Para a avaliação dos 219 documentos, na busca de artigos que analisassem o processo e experiências de recuperação de energia a partir de efluentes domésticos, os artigos foram classificados a partir do título, das palavras chaves e resumo, entre as seguintes temáticas: Tecnologia, Gestão, Impacto e Outros. A categoria Tecnologia se refere a artigos que apresentavam discussões específicas sobre técnicas, equipamentos e procedimentos utilizados para a recuperação de energia a partir dos efluentes domésticos; a categoria Gestão envolve artigos que discutem o arranjo da infraestrutura gerencial e administrativa para a otimização da gestão do efluente doméstico, para que haja o aproveitamento energético; a categoria Impacto engloba temas relacionados, principalmente a impactos ambientais, economia de baixo carbono e emissão de Gases do Efeito Estufa; e por fim, a categoria Outros abrange os artigos que não tratam sobre efluentes domésticos ou se aprofundam em detalhes técnicos e demasiadamente específicos sobre o tratamento de efluentes, que não são o foco deste estudo. A partir desta avaliação, os artigos que compuseram a Categoria Outros foram excluídos da seleção de revisão de literatura.

Os principais documentos excluídos da segunda amostra, em sua maioria, não estavam relacionados ao tratamento de esgoto doméstico, tinham como foco a recuperação de nutrientes como o fósforo, por exemplo, abordavam de forma muito específica o funcionamento de uma tecnologia ou estavam repetidos entre a base de dados coletada pelo ScienceDirect e o Web of Science. No total restaram 95 artigos para ser feita a leitura completa e estes foram classificados em subcategorias para identicar de forma mais detalhada as principais temáticas abordadas, conforme apresentado na Figura 1. 
Figura 1 - Esquema da seleção de artigos pela metologia de revisão sistemática da literatura.

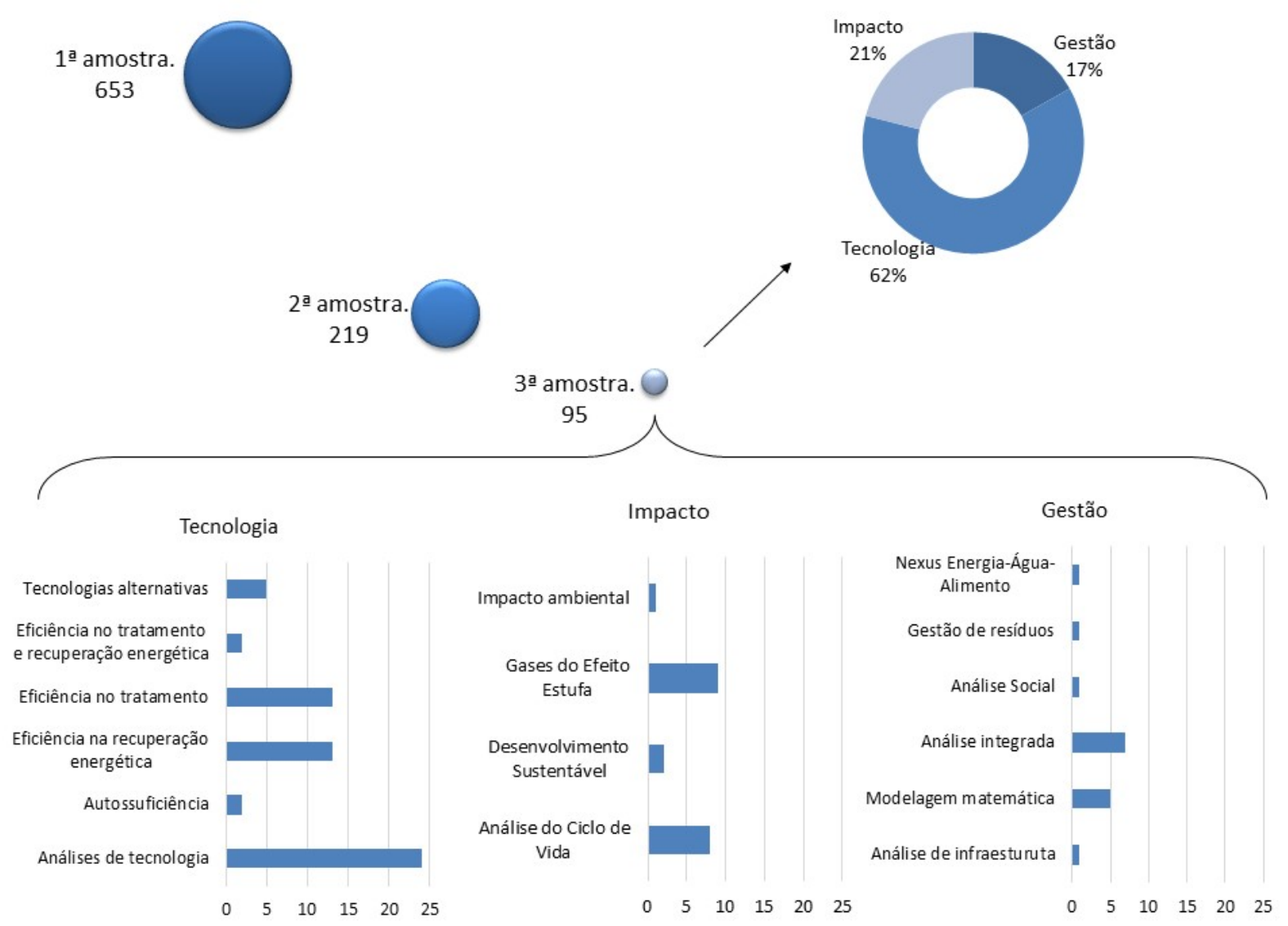

Fonte: Elaborado pela própria autora.

Além disto, foi feito um levantamento dos principais países presentes no levantamento, conforme Figura 2, onde percebe-se o predomínio das publicações provenientes da China e dos Estados Unidos. 
Figura 2 - Divisão dos artigos selecionados por país.

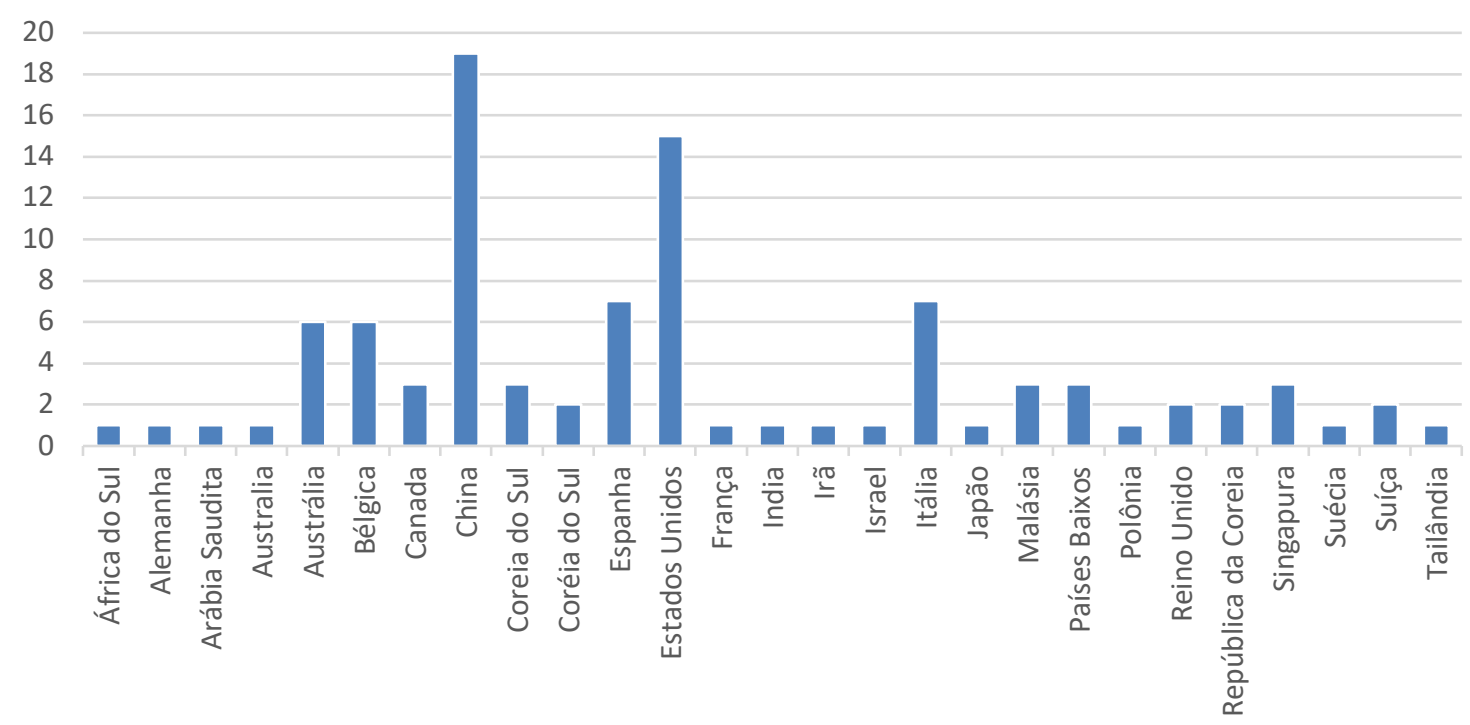

Fonte: Elaborado pela própria autora.

As referências e a categorização de todos artigos lidos se encontram no Apêndice A.

Além da fonte de pesquisa de artigos no ScienceDirect e Web of Science, outras fontes foram utilizadas, são elas:

- Artigos científicos de outras bases encontrados durante o processo da pesquisa, por recomendações ou por busca ativa;

- Relatórios de instituições renomadas, nacionais e internacionais;

- Dissertações de mestrado e teses de doutorado;

- Literatura clássica em livros, acerca de temas específicos;

- Legislação vigente;

A compilação dos artigos selecionados pela revisão sistemática foi realizada no início da pesquisa, enquanto que o restante dos documentos foi agregado ao longo do período de elaboração da pesquisa. Desta forma, foi realizada uma avaliação sistemática do conteúdo convertendo e combinando interpretações similares ou divergentes para embasar a revisão de literatura, aprofundando a pesquisa em certos tópicos, permitindo assim uma análise crítica das informações disponíveis atualmente e suas variadas interpretações provenientes de pesquisadores e outros atores (NEUENDORF, 2017). Cada documento foi lido, interpretado, grifado e trechos relevantes foram sintetizados e transpostos para a pesquisa a partir da 
perspectiva da autora, onde foram combinados temas complementares para melhor arranjo na pesquisa.

\subsection{Esgotamento sanitário no Brasil}

Segundo a UNESCO (2012), as projeções estimam que haja um aumento global na demanda por unidades de tratamento de efluentes domésticos, principalmente nos países em desenvolvimento, tendo em vista que nestes locais, grande parte desta água residuária ainda não apresenta destinação ambientalmente adequada. De acordo com a UN WATER (2015), apenas $20 \%$ de todo o esgoto sanitário produzido no mundo possui tratamento adequado.

A falta de um tratamento apropriado dos efluentes acarreta degradação da qualidade da água, ocasionada principalmente pelo despejo de esgoto bruto em locais irregulares. Isto é uma das principais causas de problemas de saúde pública, gerado pela transmissão de doenças e escassez de água potável. A redução da disponibilidade de água potável exige ainda investimentos em melhores sistemas de tratamento de água. Lane et al. (2015) destaca que com o passar do tempo a complexidade dos sistemas de tratamento de água tem aumentado, com o intuito de melhorar a qualidade da água disponível para a sociedade, devido aos crescentes índices de poluição por esgoto. Por estes e outros motivos, existe a demanda de ampliação da coleta e do número de plantas de tratamento de efluentes no mundo.

No caso brasileiro, o compilado de informações, aponta que a cobertura para coleta e tratamento de esgoto em todo o Brasil varia entre $45 \%$ a $55 \%$. As principais fontes de dados de saneamento do país provêm do Instituto Brasileiro de Geografia e Estatística (IBGE), Agência Nacional de Águas (ANA) e o Ministério das Cidades. Pelo IBGE tem-se o Atlas do Saneamento de 2011, com mapas apontando a abrangência e o volume coletado e tratado por município; pela ANA tem-se o Atlas Esgoto 2017 com informações mais detalhadas de 2013 sobre a cobertura e infraestrutura de esgotamento sanitário no país; e anualmente o Ministério das Cidades, por meio do Sistema Nacional de Informações sobre Saneamento (SNIS), desenvolve anualmente o Diagnóstico dos Serviços de Água e Esgoto.

As informações do SNIS são provenientes de companhias estaduais, autarquias municipais, empresas privadas e, das próprias prefeituras, todos denominados no SNIS como prestadores de serviços. No caso das informações do Atlas de Esgoto elaborado em 2017 pela ANA, são dados provenientes de reuniões técnicas também com companhias estaduais, autarquias municipais, empresas privadas e prefeituras, além de visitas a campo em um grupo de 
municípios, e coleta de informações de fontes secundárias para os demais municípios. Por fim, a informação do IBGE provém do Censo Demográfico de 2010.

Com base nas informações provenientes do SNIS (2018), sobre a coleta e tratamento do esgoto doméstico, observa-se que o índice médio de coleta do país chega a 46,3\% para a estimativa do esgoto gerado, e 74,5\% de tratamento para o esgoto que é coletado. Em se tratando dos dados regionais, destacam-se a região Centro-Oeste com tratamento de 53,9\% do esgoto gerado e $93,8 \%$ para o esgoto coletado; e a região Sul, com tratamento de $45,4 \%$ do esgoto gerado e $95 \%$ do esgoto coletado. Por sua vez, nas demais regiões do país, a região Sudeste realiza o tratamento de $50,1 \%$ do esgoto gerado e $67,5 \%$ do esgoto coletado; a região Nordeste trata $36,2 \%$ do esgoto gerado e $83,6 \%$ do esgoto coletado; e por fim, a região Norte trata $21,7 \%$ do esgoto gerado e $83,4 \%$ do esgoto coletado.

Com vistas a melhoria do saneamento, com um diagnóstico de cada município, e planejamento de projetos a serem executados para os próximos anos, é necessário que cada município possua seu Plano Municipal de Saneamento Básico (PMSB). Segundo o Instituto Trata Brasil, aproximadamente 41,5\% dos municípios brasileiros possuem PMSB, considerando documentos regulamentados ou não. A antiga Lei do Saneamento $\mathrm{N}^{\mathrm{o}}$ 11.445/2007, após diversas prorrogações, colocava como data limite 31 de dezembro de 2019, para os municípios finalizarem seus PMSBs, contudo por meio do Decreto No 10.203/2020, o prazo foi postergado para 31 de dezembro de 2022.

Com este panorama e considerando a meta de 2033 de universalização do serviço definida pelo Plano Nacional de Saneamento (Plansab), os dados demonstram que o país se encontra ainda muito distante do acesso universal e tem muito por fazer. A situação é particularmente mais delicada no que diz respeito ao acesso à rede coletora de esgoto, pois o impacto na saúde pública e no meio ambiente ocasionado pela falta deste serviço básico traz inúmeras consequências à população. Desta forma, foi aprovada a Lei No $14.026 / 2020$ com o novo Marco Regulatório do setor, com o intuito de acelerar as melhorias no saneamento no país. Contudo, existem diversas discussões acerca dos benefícios e prejuízos que alguns artigos da Lei possam causar no cenário do setor para sua ampliação e melhoria, principalmente no que se refere aos pequenos municípios, que não apresentam viabilidade econômica e financeira para investimentos e para sua operação (MERCEDES, 2002).

De acordo com Breach (2018), a principal dificuldade para criar novas plantas de tratamento em diversas regiões do mundo está relacionada ao elevado investimento na sua construção e operação. Segundo Sato, Qadir, Yamamoto (2013), 70\% do esgoto doméstico é tratado em países de renda elevada, enquanto apenas $8 \%$, em média, é tratado em países de baixa renda. É 
notável então, a relação direta da abrangência do tratamento de efluentes à condição econômicofinanceira da nação. Apesar de ser um investimento de fundamental importância no longo prazo para o desenvolvimento sustentável do país, a construção de plantas de tratamento de esgoto passa primeiramente pela análise do potencial econômico ou de mercado para implantação, no curto prazo (MARIANI, 2018).

$\mathrm{Na}$ seção sobre as tecnologias de tratamento de efluentes domésticos são detalhadas as principais formas de tratamento no país e seu funcionamento, tanto para tratamento de esgoto, quanto para recuperação energética, e as condicionantes para adoção desses projetos.

\subsection{Recuperação energética a partir de esgoto doméstico no Brasil}

A recuperação energética do esgoto doméstico pode ser realizada por meio do biogás ou do lodo do esgoto. Desta forma, vale lembrar que o biogás é uma mistura gasosa combustível, produzida através da digestão anaeróbia, processo fermentativo que tem como finalidade a remoção de matéria orgânica, a formação de biogás e a produção de biofertilizantes ricos em nutrientes. A composição usual do biogás é de $60 \%$ metano, $35 \%$ dióxido de carbono e $5 \%$ de mistura de hidrogênio, nitrogênio, amônia, ácido sulfídrico, monóxido de carbono, aminas voláteis e oxigênio (PERUZZO, 2017; RASI; VEIJANEN; RINTALA, 2007). Dependendo da eficiência do processo, influenciado por fatores como pressão e temperatura durante a fermentação, o biogás pode conter diferentes percentuais de metano (COELHO; VELAZQUEZ; SILVA, 2006). Já o lodo do esgoto é composto por bactérias e material decomposto por estas, sendo também uma fonte de energia e um excelente fertilizante (PECORA, 2006).

As formas de recuperação energética a partir do efluente podem ocorrer na forma de energia térmica, elétrica, mecânica ou como combustível. Para isto, é utilizado o próprio efluente doméstico ou o lodo gerado a partir do tratamento do efluente. São diversas as formas de tratar os efluentes domésticos, que serão detalhadas na próxima seção, e que influenciam na forma de recuperação energética.

No caso de ETEs que utilizam processos aeróbios, a recuperação pode ser feita a partir do lodo gerado, que passa por um processo de secagem e em seguida é incinerado, com o objetivo principal de gerar energia térmica. $\mathrm{O}$ uso de incineração de lodo pode ser inviável em plantas de tratamento aeróbio de pequena escala (BREACH, 2018), devido aos elevados custos.

No caso dos processos anaeróbios, existem diversos tipos de reatores anaeróbios, variando em complexidade, escala e arranjo com outras tecnologias. Os reatores podem ser utilizados em 
grande escala em regiões metropolitanas ou em pequena escala na zona rural. Nos grandes centros, estes utilizam efluentes domésticos como substrato e o biogás produzido costuma ser convertido em energia elétrica, enquanto que na zona rural, os dejetos animais e resíduos agrosilviopastoris são, na maioria dos casos, utilizados como substrato e o biogás é utilizado diretamente como energia térmica ou elétrica na indústria, ou de forma caseira, pelas famílias, sem ser convertido em energia elétrica (LARAMEE; TILMANS; DAVIS, 2018).

Com relação ao biogás, no Brasil, em 2019, foram mapeadas 521 plantas de pequeno, médio e grande porte, em operação. O porte das plantas de biogás é definido segundo a sua produção, como apresentado na Tabela 3. A CIBiogas (2018) classifica as plantas ainda como: escala doméstica ou escala produtiva, onde a escala produtiva pode ser de pequeno, médio ou grande porte a partir da produção de biogás.

Tabela 3 - Definição do porte das plantas de biogás.

\begin{tabular}{ccc}
\hline Classificação & Subclassificação & $\begin{array}{c}\text { Produção de biogás } \\
\left(\mathbf{m}^{\mathbf{3}} \mathbf{\text { dia) }}\right)\end{array}$ \\
\hline $\begin{array}{c}\text { Pequeno } \\
\text { porte }\end{array}$ & Porte 1 & $<1.250$ \\
\hline \multirow{2}{*}{ Médio porte } & Porte 2 & $1.251-2.500$ \\
\hline \multirow{2}{*}{ Grande porte } & Porte 3 & $2.501-8.500$ \\
\cline { 2 - 3 } & Porte 4 & $8.501-12.500$ \\
\cline { 2 - 3 } & Porte 5 & $12.501-85.500$ \\
\hline Fonte:(MARIANI; KAZUE NAKAO CAVALIERO, 2018).
\end{tabular}

No que se refere ao uso do biogás, no país, por tipo de aplicação energética, a Tabela 4 apresenta as informações sobre esta distribuição, onde há o predomínio do uso para a geração de energia elétrica em primeiro lugar, e para a energia térmica, em segundo.

Tabela 4 - Classificação por aplicação energética do biogás das plantas em operação no Brasil em 2019.

\begin{tabular}{lcccc}
\hline $\begin{array}{c}\text { Principal aplicação } \\
\text { energética do biogás }\end{array}$ & \multicolumn{2}{c}{ Quantidade de plantas } & \multicolumn{2}{c}{$\begin{array}{c}\text { Volume de biogás } \\
\left(\mathbf{N m}^{3} / \mathbf{a n o}\right)\end{array}$} \\
\hline Energia elétrica & 439 & $84 \%$ & 1.168 .138 .811 & $86 \%$ \\
\hline Energia térmica & 70 & $14 \%$ & 132.094 .572 & $10 \%$ \\
\hline GNR/Biometano & 6 & $1 \%$ & 37.739 .175 & $3 \%$ \\
\hline Energia mecânica & 6 & $1 \%$ & 7.526 .112 & $1 \%$ \\
\hline Total & 521 & $100 \%$ & 1.345 .498 .670 & $100 \%$ \\
\hline
\end{tabular}

Fonte: CIBIOGÁS, 2020. 
Dentre as plantas produtoras de biogás no país, $76 \%$ são de pequeno porte e produzem o equivalente a $9 \%$ do volume total do país, enquanto que $6 \%$ são de grande porte e produzem $77 \%$ do volume de biogás. Deste montate de 521 plantas, os resíduos sólidos urbaos e esgoto doméstico representam $8 \%$, e produzem $76 \%$ do volume de biogás no país. Parte significativa das plantas de resíduos são de grande porte, onde predominam os aterros sanitários e ETEs, conforme Tabela 5 (CIBIOGÁS, 2020; MARIANI, 2018).

Tabela 5 - Plantas de produção de biogás no Brasil.

\begin{tabular}{lcccc}
\hline $\begin{array}{c}\text { Origem do } \\
\text { substrato }\end{array}$ & Quantidade de plantas & \multicolumn{2}{c}{$\begin{array}{c}\text { Volume de biogás } \\
\left(\mathbf{N m}^{3} / \mathbf{a n o}\right)\end{array}$} \\
\hline Agropecuária & 416 & $80 \%$ & 165.112 .571 & $12 \%$ \\
\hline Indústria & 62 & $12 \%$ & 153.858 .569 & $12 \%$ \\
\hline RSU e ETE & 43 & $8 \%$ & 1.026 .527 .529 & $76 \%$ \\
\hline Total & 521 & $100 \%$ & 1.345 .498 .669 & $100 \%$ \\
\hline${ }^{1}$ RSU: Resíduo Sólido Urbano e ETE: Estação de Tratamento de Esgoto \\
\hline Fonte: CIBIOGÁS, 2020.
\end{tabular}

Apesar das plantas de resíduos representarem parte significativa da geração de biogás no país, é o uso de Resíduos Sólidos Urbanos (RSU) em aterros sanitários que predomina, em relação ao efluente doméstico. Isto ocorre devido, não só à falta de incentivos para este tipo de aproveitamento energético, mas também pelas barreiras para uso da recuperação energética em plantas já existentes, e pela ausência de cobertura de coleta e tratamento do resíduo para aproximadamente metade da população (SNIS, 2019), dificultando a economia de escala.

A Figura 3, a seguir, apresenta a distribuição das 15 plantas de ETE com recuperação energética a partir de lodo ou do efluente doméstico, onde estão contemplados parte dos $8 \%$ das plantas da geração de biogás por resíduos no país. 
Figura 3 - ETEs com recuperação energética no Brasil.

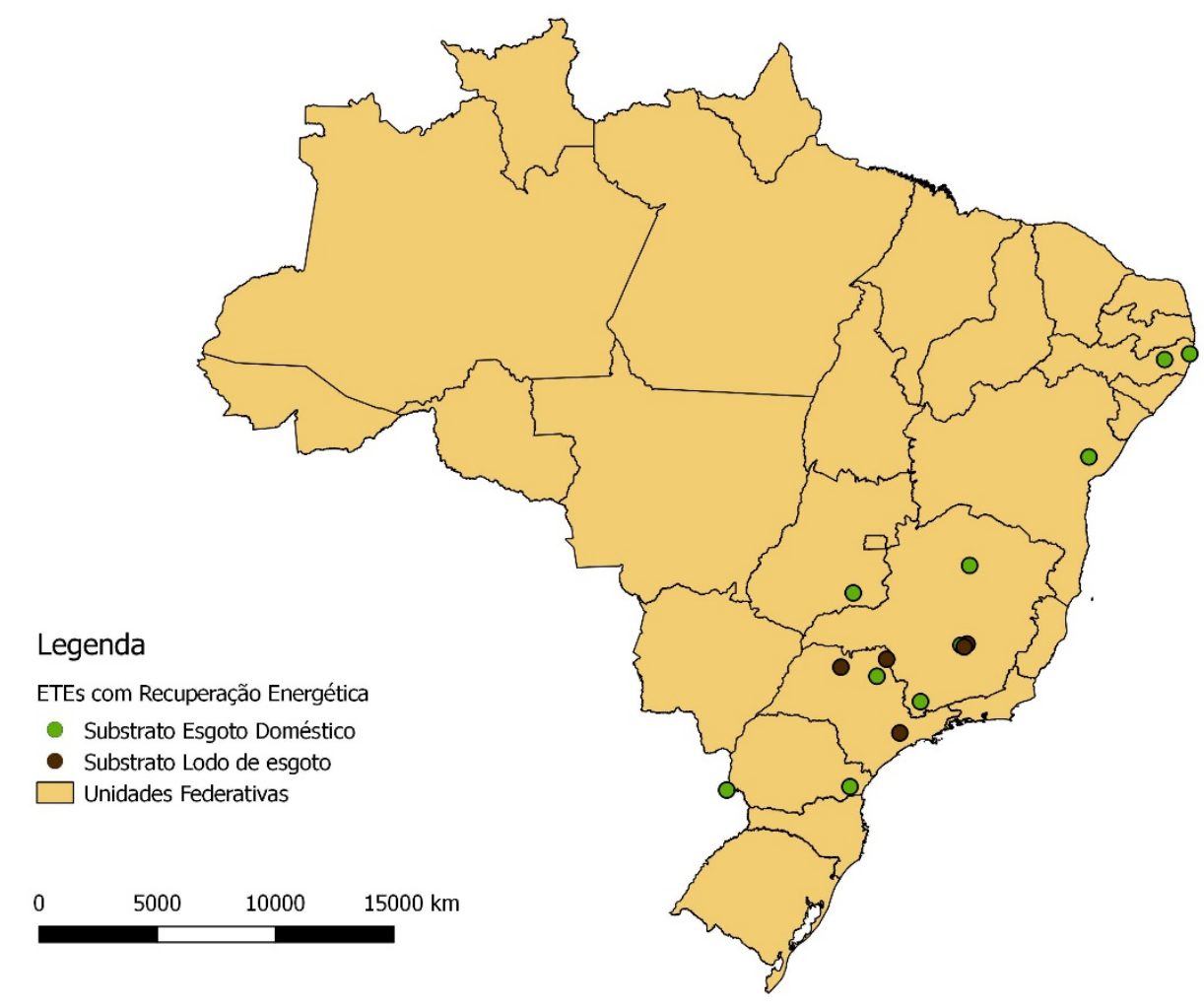

Fonte: Adaptado de ANEEL, 2019; CIBIOGAS, 2019; UNFCCC, 2019;ABIOGAS, 2020.

Segundo a Agência Nacional de Energia Elétrica (ANEEL) apenas três plantas de tratamento de esgoto doméstico oferecem a recuperação de energia a partir de esgoto por meio dos reatores anaeróbios e lodo de esgoto, e estão conectados à rede de energia elétrica no país (ANEEL, 2019). Importante considerar que as informações da ANEEL são provenientes do Banco de Informações de Geradores (BIG) e abrangem apenas as usinas outorgadas para geração de energia elétrica e que estão conectadas ao Sistema Interligado Nacional (SIN). Outras fontes de informações são: a Convenção-Quadro das Nações Unidas sobre a Mudança do Clima² (UNFCCC), a qual não indica plantas de recuperação energética de ETEs no Brasil; as informações da Associação Brasileira de Biogás (ABIOGAS, 2020), onde constam 14 plantas no início do ano de 2020; e o mapa do Centro Internacional de Energias RenováveisBiogás (CIBIOGAS, 2019), o qual apresenta dados coletados no ano de 2015 em diante, e aponta que existem: nove unidades de geração de energia térmica ou elétrica a partir do esgoto

${ }^{2}$ United Nations Framework Convention on Climate Change em inglês. 
no país, seis unidades de geração de energia elétrica ou térmica que utilizam o lodo de esgoto. Dentre estas plantas existe um caso de Biometano como Gás Natural Veicular (GNV).

Pelo mapa, observa-se a concentração destas tecnologias na região Sudeste do país. Na Tabela 6, a seguir, estão os dados detalhados das plantas mapeadas. O mapa das ETEs com recuperação energética no país ainda prescinde de informações, tendo em vista, que não existe uma base centralizadora para garantir que alguma ETE não tenha sido contabilizada. Atualmente, as bases de dados mais completas são da CIBiogás e ABiogás.

Tabela 6 - Usinas de biogás utilizando lodo e esgoto doméstico como substrato.

\begin{tabular}{|c|c|c|c|c|c|}
\hline Município & Substrato & $\begin{array}{c}\text { Produção } \\
\text { média diária } \\
\text { de biogás } \\
\left(\mathrm{Nm}^{3} / \text { dia }\right)\end{array}$ & $\begin{array}{c}\text { Situação } \\
\text { da planta }\end{array}$ & $\begin{array}{l}\text { Aplicação } \\
\text { energética } \\
\text { do biogás }\end{array}$ & Fonte de informação \\
\hline Barueri & Lodo & $\begin{array}{c}56.000 \\
\text { Grande porte }\end{array}$ & $\begin{array}{c}\text { Em } \\
\text { operação }\end{array}$ & $\begin{array}{l}\text { Energia } \\
\text { Térmica }\end{array}$ & $\begin{array}{c}\text { ANEEL/CIBIOGAS/ } \\
\text { ABIOGAS }\end{array}$ \\
\hline $\begin{array}{c}\text { Belo } \\
\text { Horizonte }\end{array}$ & Lodo & $\begin{array}{c}12.430 \\
\text { Pequeno } \\
\text { porte }\end{array}$ & $\begin{array}{c}\text { Em } \\
\text { operação }\end{array}$ & $\begin{array}{l}\text { Energia } \\
\text { Elétrica }\end{array}$ & $\begin{array}{c}\text { ANEEL/CIBIOGAS/ } \\
\text { ABIOGAS }\end{array}$ \\
\hline Betim & Esgoto & $\begin{array}{c}3.100 \\
\text { Pequeno } \\
\text { porte }\end{array}$ & $\begin{array}{c}\text { Em } \\
\text { operação }\end{array}$ & $\begin{array}{l}\text { Energia } \\
\text { Térmica }\end{array}$ & CIBIOGAS/ABIOGAS \\
\hline Camaragibe & Esgoto & $\begin{array}{c}2.226 \\
\text { Pequeno } \\
\text { porte }\end{array}$ & $\begin{array}{c}\text { Em } \\
\text { construção }\end{array}$ & $\begin{array}{l}\text { Energia } \\
\text { Elétrica }\end{array}$ & CIBIOGAS/ABIOGAS \\
\hline Caruaru & Esgoto & $\begin{array}{c}1715 \\
\text { Pequeno } \\
\text { porte }\end{array}$ & $\begin{array}{c}\text { Em } \\
\text { construção }\end{array}$ & $\begin{array}{l}\text { Energia } \\
\text { Elétrica }\end{array}$ & CIBIOGAS/ABIOGAS \\
\hline $\begin{array}{l}\text { Feira de } \\
\text { Santana }\end{array}$ & Esgoto & $\begin{array}{c}2226 \\
\text { Pequeno } \\
\text { porte }\end{array}$ & $\begin{array}{c}\text { Em } \\
\text { construção }\end{array}$ & $\begin{array}{l}\text { Energia } \\
\text { Elétrica }\end{array}$ & CIBIOGAS/ABIOGAS \\
\hline $\begin{array}{l}\text { Foz do } \\
\text { Iguaçu }\end{array}$ & Esgoto & $\begin{array}{c}50 \\
\text { Pequeno } \\
\text { porte }\end{array}$ & $\begin{array}{c}\text { Em } \\
\text { operação }\end{array}$ & $\begin{array}{l}\text { Energia } \\
\text { Elétrica }\end{array}$ & CIBIOGAS/ABIOGAS \\
\hline Franca & Lodo & $\begin{array}{c}2.500 \\
\text { Pequeno } \\
\text { porte }\end{array}$ & $\begin{array}{c}\text { Em } \\
\text { operação }\end{array}$ & $\begin{array}{c}\text { GNR/ } \\
\text { Biometano }\end{array}$ & CIBIOGAS/ABIOGAS \\
\hline Ibirité & Lodo & $\begin{array}{c}1.000 \\
\text { Pequeno } \\
\text { porte }\end{array}$ & $\begin{array}{c}\text { Em } \\
\text { operação }\end{array}$ & $\begin{array}{l}\text { Energia } \\
\text { Elétrica }\end{array}$ & CIBIOGAS/ABIOGAS \\
\hline $\begin{array}{l}\text { Montes } \\
\text { Claros }\end{array}$ & Esgoto & $\begin{array}{c}5.040 \\
\text { Pequeno } \\
\text { porte }\end{array}$ & $\begin{array}{c}\text { Em } \\
\text { operação }\end{array}$ & $\begin{array}{l}\text { Energia } \\
\text { Térmica }\end{array}$ & CIBIOGAS/ABIOGAS \\
\hline
\end{tabular}




\begin{tabular}{|c|c|c|c|c|c|}
\hline Município & Substrato & $\begin{array}{c}\text { Produção } \\
\text { média diária } \\
\text { de biogás } \\
\left(\mathrm{Nm}^{3} / \text { dia }\right)\end{array}$ & $\begin{array}{c}\text { Situação } \\
\text { da planta }\end{array}$ & $\begin{array}{l}\text { Aplicação } \\
\text { energética } \\
\text { do biogás }\end{array}$ & Fonte de informação \\
\hline $\begin{array}{l}\text { Pouso } \\
\text { Alegre }\end{array}$ & Esgoto & $\begin{array}{c}432 \\
\text { Pequeno } \\
\text { porte }\end{array}$ & $\begin{array}{c}\text { Em } \\
\text { operação }\end{array}$ & $\begin{array}{l}\text { Energia } \\
\text { Elétrica }\end{array}$ & CIBIOGAS/ABIOGAS \\
\hline $\begin{array}{l}\text { Ribeirão } \\
\text { Preto }\end{array}$ & Lodo & $\begin{array}{c}8.000 \\
\text { Pequeno } \\
\text { porte }\end{array}$ & $\begin{array}{c}\text { Em } \\
\text { operação }\end{array}$ & $\begin{array}{l}\text { Energia } \\
\text { Elétrica }\end{array}$ & $\begin{array}{c}\text { ANEEL/CIBIOGAS/ } \\
\text { ABIOGAS }\end{array}$ \\
\hline Rio Quente & Esgoto & 200 & $\begin{array}{l}\text { Em } \\
\text { reforma }\end{array}$ & $\begin{array}{l}\text { Energia } \\
\text { Elétrica }\end{array}$ & CIBIOGAS \\
\hline $\begin{array}{l}\text { São José do } \\
\text { Rio Preto }\end{array}$ & Esgoto & $\begin{array}{c}7.800 \\
\text { Pequeno } \\
\text { porte }\end{array}$ & $\begin{array}{c}\text { Em } \\
\text { operação }\end{array}$ & $\begin{array}{l}\text { Energia } \\
\text { Elétrica }\end{array}$ & CIBIOGAS/ABIOGAS \\
\hline $\begin{array}{c}\text { São José } \\
\text { dos Pinhais }\end{array}$ & Esgoto & $\begin{array}{c}32.877 \\
\text { Médio porte }\end{array}$ & $\begin{array}{c}\text { Em } \\
\text { operação }\end{array}$ & $\begin{array}{l}\text { Energia } \\
\text { Elétrica }\end{array}$ & CIBIOGAS/ABIOGAS \\
\hline
\end{tabular}

Fonte: Adaptado de ANEEL, 2019; CIBIOGAS, 2019; UNFCCC, 2019; ABIOGAS, 2020.

Com este panorama da situação do esgotamento sanitário e sua recuperação energética, observa-se que existe potencial de melhor aproveitamento dos efluentes domésticos no país, para a geração de energia, e especialmente de biogás (BILOTTA; ROSS, 2016; CIBIOGÁS, 2020), que pode ocorrer de forma centralizada ou descentralizada.

Cumpre destacar ainda, que atualmente, os cenários de políticas públicas em prol do biogás no país beneficiam de forma incipiente o setor. O RenovaBio foi um programa lançado em 2016, o qual favorece diversas formas de geração de energia renovável, incluindo soluções que utilizam o biogás, no qual prevê a geração de certificados verdes para o biometano, que representa $1 \%$ das plantas de recuperação energética de resíduos no Brasil (CIBIOGÁS, 2020). Contudo, é crescente o mercado do biometano proveniente de aterros. As plantas para biometano de lodo de ETE ou ETA e de resíduos agrosilvipastoris ainda é incipiente.

A iniciativa mais atual direcionada ao setor, foi o lançamento da Frente Brasil de Recuperação Energética de Resíduos (FBRER) no dia 02 de junho de 2020, iniciativa que formalizou a assinatura de um Termo de Cooperação entre a Associação Brasileira de Cimento Portland (ABCP), Associação Brasileira de Empresas Tratamento de Resíduos e Efluentes (ABETRE), Associação Brasileira do Biogás (ABIOGAS) e a Associação Brasileira de Empresas de Limpeza Pública e Resíduos Especiais (ABRELPE) com o objetivo de impulsionar a captação de energia a partir de resíduos no país. Neste primeiro momento, a Frente não definiu os tipos de resíduos a serem trabalhados, mas aparenta estar com foco em Resíduos Sólidos 
Urbanos (RSU). Não foi definida também as aplicações energéticas, tipos de incentivos, entre outros detalhes, contudo se consolida como um primeiro passo para auxiliar no desenvolvimento de políticas públicas para o setor.

Neste sentido, espera-se que esta Frente englobe as necessidades da área da recuperação energética de resíduos, pois esta demanda uma política específica que considere as condições locais, o potencial do substrato, a tecnologia adequada, a melhor forma de aproveitamento de energia, entre outros aspectos. Atrelado a isto, sabe-se que, o desenvolvimento de políticas do setor de resíduos e biogás favorece o setor de saneamento gerando externalidades e benefícios sinérgicos para ambos os setores (MARIANI, 2018), logo é um benefício a ser considerado.

\subsection{Tecnologias de tratamento de esgoto e recuperação energética}

Para atingir a cobertura atual de esgotamento sanitário no Brasil, são utilizadas majoritariamente tecnologias convencionais de tratamento de esgoto doméstico, utilizando a oxidação biológica, a qual pode ser aeróbia, anaeróbia ou facultativa. As principais tecnologias são filtros biológicos; lodos ativados; lagoas de estabilização; e os reatores anaeróbios (INCT, 2021). Atualmente, tecnologias como os Biorreatores de Membrana, também tem se destacado como uma alternativa.

São diversos os estudos que buscam opções para compreender e otimizar o processo de tratamento de esgoto e sua recuperação energética. A mudança de persectiva sobre o potencial da recuperação energética a partir de efluentes tem feito com que plantas de Tratamento de Esgoto, sejam pensadas como plantas de Recuperação de Recursos, considerando a possibilidade da recuperação de recursos como energia, nutrientes e bioprodutos (FERNÁNDEZ-ARÉVALO et al., 2017; ZHANG et al., 2018).

A Tabela 7, a seguir, explica a forma de tratamento de cada uma das tecnologias utilizadas no país para tratamento de efluentes domésticos.

Tabela 7 - Principais tecnologias de tratamento biológico de esgoto doméstico.

\begin{tabular}{ccc}
\hline $\begin{array}{c}\text { Tipo de } \\
\text { tratamento }\end{array}$ & Tecnologia & Definição da tecnologia \\
\hline $\begin{array}{c}\text { Aeróbio e } \\
\text { Anaeróbio }\end{array}$ & Filtro biológico & $\begin{array}{c}\text { Processo em que o esgoto afluente entra em contato com a } \\
\text { massa biológica contida em um meio de suporte fixo e é } \\
\text { realizada a oxidação bioquímica do esgoto, com a adsorção } \\
\text { da matéria orgânica. Possui basctérias aeróbias, anaeróbias e } \\
\text { facultativas, com predomínio das facultativas. Lodo está } \\
\text { aderido a um material de suporte. }\end{array}$ \\
\hline
\end{tabular}




\begin{tabular}{|c|c|c|}
\hline $\begin{array}{l}\text { Tipo de } \\
\text { tratamento }\end{array}$ & Tecnologia & Definição da tecnologia \\
\hline \multirow[t]{2}{*}{$\begin{array}{l}\text { Aeróbio e } \\
\text { Anaeróbio }\end{array}$} & $\begin{array}{l}\text { Lagoas de } \\
\text { facultativa }\end{array}$ & $\begin{array}{l}\text { Processo que ocorre a estabilização da matéria orgânica, onde } \\
\text { a parte superior é composta por uma zona aeróbia com a } \\
\text { oxidação aeróbia e a redução fostossintética, e uma zona } \\
\text { anaeróbia na camada abaixo, onde ocorre fermentação } \\
\text { anaeróbia. }\end{array}$ \\
\hline & $\begin{array}{l}\text { Biorreator de } \\
\text { Membrana } \\
\text { (MBR) }\end{array}$ & $\begin{array}{c}\text { Processo que combina os processos de tratamento biológicos } \\
\text { de efluentes com o processo de separação por membranas. Os } \\
\text { sistemas de BRM permitem a retenção de flocos bacterianos } \\
\text { e sólidos suspensos dentro do biorreator }\end{array}$ \\
\hline \multirow{3}{*}{ Aeróbio } & Lodos ativados & $\begin{array}{l}\text { Processo que ocorre em lagoa aerada, em que esgoto afluente } \\
\text { e lodo ativado são misturados em tanques de aeração, onde a } \\
\text { massa biológica é móvel, com recirculação de lodo. Pode ser } \\
\text { operação contínua ou por batelada. }\end{array}$ \\
\hline & Lagoa aeróbia & $\begin{array}{l}\text { Processo que ocorre em lagoa aerada utilizando } \\
\text { equipamentos de aeração, não possui sistema de recirculação } \\
\text { de lodo (sólidos). Devido a inexistência da recirculação, a } \\
\text { concentração de sólidos dentro das lagoa é menor ( } 20 \text { a } 30 \\
\text { vezes) do que em sistemas de lodos ativados. }\end{array}$ \\
\hline & $\begin{array}{l}\text { Valos de } \\
\text { oxidação }\end{array}$ & $\begin{array}{l}\text { Processo de tratamento em unidade compacta com } \\
\text { funcionamento similar ao de lodo ativado que possui aeração } \\
\text { prolongada. Não necessita de decantação primária, } \\
\text { secundária e recirculação do lodo. }\end{array}$ \\
\hline
\end{tabular}
Reator Anaeróbio de Leito
Fluidizado ou
Expandido
(RALF)
Processo que ocorre dentro de reator, em que esgoto entra em contato com o lodo, que se encontra aderido à superfície de material particulado e móvel, formando um biofilme, e onde ocorre a disgestão anaeróbia da matéria orgânica.

\section{Anaeróbio de Manta de Lodo e Fluxo \\ Ascendente \\ (UASB)}

Processo que ocorre dentro de reator, em que esgoto entra em contato com a manta de lodo em suspensão, agregado na forma de floco, e ocorre a disgestão anaeróbia da matéria orgânica. Este reator também é conhecido como Reator Anaeróbio ou Digestor Anaeróbio de Fluxo Ascendente (RAFA e DAFA)

\begin{tabular}{cc}
\hline $\begin{array}{c}\text { Reator Anaeróbio } \\
\text { de Fluxo }\end{array}$ & $\begin{array}{c}\text { Processo que ocorre dentro de reator, em que esgoto entra em } \\
\text { contato com a manta de lodo fixa, agregado na forma de } \\
\text { Ascendente e } \\
\text { floco, e ocorre a disgestão anaeróbia da matéria orgânica. } \\
\text { Fixa (UAFB) }\end{array}$ \\
\hline $\begin{array}{c}\text { Lagoas } \\
\text { anaeróbias }\end{array}$ & $\begin{array}{c}\text { Processo que ocorre em lagoa, onde predomina a } \\
\text { fermentação anaeróbia, logo abaixo da superfície, onde não } \\
\text { existe oxigênio dissolvido. }\end{array}$ \\
\hline
\end{tabular}

Processo que ocorre dentro de uma câmara, em que o esgoto

Tanques sépticos

(Fossa séptica)

fica retido por um período de tempo, onde os sólidos sedimentam, ocorre a retenção do matérial graxo do esgoto e a digestão anaeróbia, removendo material volátil e patôgenos.

Torna as substâncias mais estáveis e reduz potencial 


\begin{tabular}{|c|c|c|}
\hline $\begin{array}{c}\text { Tipo de } \\
\text { tratamento }\end{array}$ & Tecnologia & Definição da tecnologia \\
\hline \multirow{3}{*}{ Anaeróbio } & & $\begin{array}{c}\text { poluidor. Costuma ter aplicação domiciliar e o efluente do } \\
\text { tanque deve passar por processos posteriores, como filtro } \\
\text { biológico. }\end{array}$ \\
\hline & $\begin{array}{l}\text { Biorreator de } \\
\text { Membrana } \\
\text { Dinâmica (MBR) }\end{array}$ & $\begin{array}{l}\text { Processo que combina a digestão anaeróbia com o processo } \\
\text { de separação por membrana e membrana dinâmica, formada } \\
\text { por uma fina camada de partículas, que colabora na retenção } \\
\text { de coloides que antes atravessavam os poros da membrana. }\end{array}$ \\
\hline & $\begin{array}{l}\text { Biorreator de } \\
\text { Membrana } \\
\text { Dinâmica } \\
\text { Anaeróbio } \\
\text { (AnMBR) }\end{array}$ & $\begin{array}{l}\text { Processo que combina o uso de reatores com o processo de } \\
\text { separação por membranas. A combinação desses dois } \\
\text { sistemas (digestão anaeróbia e separação por membrana) } \\
\text { garante a manutenção de microrganismos responsáveis pela } \\
\text { degradação de material orgânico, e proporciona um obstáculo } \\
\text { (barreira) para os poluentes que se encontram suspensos nas } \\
\text { águas residuárias. }\end{array}$ \\
\hline
\end{tabular}

Fonte: Adaptado de D'AQUINO, 2018; JORDAO; PESSOA, 2017; PORTAL TRATAMENTO DE ÁGUA, 2020; STAZI; TOMEI, 2018.

Com relação ao aspecto tecnológico, as tecnologias da Tabela 7 são as principais, mas pode ser utilizada ainda a solução de disposição no solo, de forma a fornecer nutrientes para a agricultura. Importante destacar que as soluções podem ser conjugadas, como no caso de lagoas de estabilização e lodo ativado que utilizam processos aeróbios e anaeróbios durante o tratamento, conforme é apresentado no ANEXO I. Nesta tabela são apresentadas as variadas soluções conjuntas e sua quantidade no Brasil, assim como a eficiência média de remoção de DBO destas.

Referente às faixas de remoção de DBO, estas variam conforme a combinação das tecnologias, e desta forma as soluções podem ser consideradas: convencionais, quando atingem entre $60 \%$ a $80 \%$ de remoção de DBO, e avançadas, quando atingem remoção de $80 \%$ de DBO. Em certos casos, é necessária uma solução complementar ou conjunta às tecnologias, devido à elevada concentração da carga orgânica presente no efluente (ANA, 2017).

Com base nos dados levantados, as principais tecnologias utilizadas no Brasil, são os lodos ativados, que correspondem a $15 \%$ das plantas, mas que abrangem em torno de $26 \%$ da população que tem acesso a coleta e tratamento de esgoto, aproximadamente 27 milhões de pessoas; as tecnologias que contemplam o uso de lagoas correspondem a $44 \%$ das plantas, e abrange em tornor $18 \%$ da população, aproximadamente 18 milhões de pessoas, e por fim, as tecnologias de reatores anaeróbios estão presentes em 39\% das ETEs, contemplando $20 \%$ da 
população, com o alcance de 21 milhões de habitantes (ANA, 2017). Por fim, existem soluções individuais como as fossas sépticas, que apresentam um percentual significativo no país. No caso do ANEXO I, são apresentadas fossas apenas em situação de utilização para solução coletiva e aplicada em ETE, por esta razão não indicam um valor expressivo.

Todas as tecnologias acima mencionadas na Tabela 7 são utilizadas em Estações de Tratamento de Esgoto (ETE) que podem ser de grande, médio ou pequeno porte, com base na vazão afluente (SANEPAR, 2017).

Estas tecnologias estão difundidas por todo o país e apresentam o potencial de adaptação para o aproveitamento da recuperação energética, contudo não se tem as informações detalhadas de cada uma. Com base no levantamento feito pelo Atlas do Esgoto (ANA, 2017) e nos estudos realizados pelo desempenho no tratamento das ETEs brasileiras (OLIVEIRA; SPERLING, 2005) é possível iniciar uma análise das condições de cada ETE no Brasil e seu potencial de geração de energia a partir do efluente e do lodo. Importante também que se mantenha a base de dados das ETEs brasileiras atualizadas, e preferenciamente georreferenciadas, de forma a facilitar as análises sobre as condições a que estão submetidas, e desta maneira aprimorar a avaliação sobre a recuperação energética a partir de efluentes no país.

A seguir, as tecnologias mais utilizadas para tratamento de efluentes e com potencial para recuperação energética são comentadas:

\section{Lagoas de Estabilização}

Os sistemas de tratamento de esgoto por lagoa de estabilização, comumente encontrados no país, permitem que o efluente tratado cumpra os requisitos das normas, removendo substâncias poluentes e nutrientes em excesso. Contudo, são considerados sistemas robustos e com um elevado consumo de energia, principalmente devido à utilização dos aeradores, que correspondem a aproximadamente metade de toda a energia consumida pela unidade de tratamento, no caso da lagoas aeróbias (MCCARTY; BAE; KIM, 2011).

Os diversos tipos de lagoas de estabilização no Brasil, representam percentual significativo de ETEs no país (ANA, 2017). Esta tecnologia é adequada para o Brasil pelas condições favoráveis do clima e apresenta eficiência significativa para o tratamento dos efluentes com uma remoção de DBO de aproximadamente $60 \%$ a $80 \%$, onde a combinação de lagoas em série apresenta maior eficiência no tratamento. O lodo das lagoas são muito utilizados para utilização na agricultura, como definido pelas Diretrizes da Organização Mundial da Saúde e Conselho 
Nacional do Meio Ambiente (CONAMA) na Resolução No 430/2011 (JORDAO; PESSOA, 2017).

As lagoas servem comumente como soluções de grande porte, mas também são alternativas para pequenas comunidades e/ ou áreas rurais que podem utilizar painéis fotovoltaicos para gerar energia para os aeradores, no caso de lagoas aeradas (JIANG et al., 2018).

Com relação à recuperação energética deste tipo de tratamento, tendo em vista que as lagoas são a céu aberto, as condições para coleta de biogás são restritas, logo o lodo pode ser utilizado como substrato para recuperação energética, por digestão ou incineração, ou para disposição em solo, como fertilizante na agricultura, considerando os padrões da legislação. O cálculo da Atividade Metanogênica do Lodo (AME) permite avaliar a qualidade do lodo, sua degradabilidade do efluente e a presença de componentes tóxicos para determinar a capacidade de digestão (JORDAO; PESSOA, 2017).

\section{Lodos Ativados}

Segundo dados do Atlas do Esgoto (ANA, 2017), aproximadamente 15\% das ETEs utilizam a tecnologia de lodos ativados no país. Esta tecnologia pode ser utilizada em conjunto com reatores anaeróbios e lagoas de estabilização. O desempenho obtido no tratamento de efluentes com esta tecnologia é considerado eficiente em comparação a outras tecnologias avaliadas como Lagoas de Estabilização, Reatores e Fossas Sépticas, no estudo de ETEs brasileiras (OLIVEIRA; SPERLING, 2005).

Para a recuperação energética, a tecnologia de tratamento por Lodo Ativado (HRAS), com posterior uso do lodo em um digestor anaeróbio, é uma possibilidade, assim como para o uso da biomassa carbonizada para geração de energia (biochar) (NANSUBUGA et al., 2015).

\section{Reatores}

Dentre os reatores mais conhecidos e utilizados estão: os reatores anaeróbios de mistura completa (CSTR), os reatores anaeróbios de manta de lodo e fluxo ascendente (UASB), digestores anaeróbios de contato ou biorreatores de membrana, filtros anaeróbios e reatores anaeróbios de leito fluidizado (RALF) (CETESB, 2019).

Até o momento, o processo mais utilizado para o tratamento de efluentes domésticos é o tratamento anaeróbio por meio de Reatores Anaeróbios de Fluxo Ascendente (RAFA), que englobam o reator UASB e suas variações, com a capacidade de aportar diversos tipos de 
substratos, inclusive com elevado teor de umidade, de impurezas e sem um tratamento prévio, além de possibilitar a recuperação de energia contida no efluente de forma mais eficiente (APPELS et al., 2011). Dentre os reatores mais utilizados, o modelo de reator anaeróbio de manta de lodo e fluxo ascendente (UASB) possui diversos benefícios, como baixo consumo de energia e baixo custo operacional (TSUTIYA; HIRATA, 2001). Apesar disto, são necessários tratamentos posteriores e complementares para cumprir com os padrões de lançamento de efluentes conforme as normas da CONAMA No 430/2011. Neste caso, o benefício dos reatores está relacionado, principalmente, à demanda de menor espaço para implantação, menor volume, menor consumo energético e menor geração de lodo (VON SPERLING; CHERNICARO, 2005), assim como melhores condições de coleta do biogás.

Segundo o Atlas do Esgoto (ANA, 2017), no Brasil, aproximadamente 39\% das ETEs utiliza reatores como única solução ou conjugado com outra tecnologia para tratamento dos efluentes. A tecnologia já é bem difundida no Brasil e no início era utilizada exclusivamente para efluentes de alta taxa, contudo a tecnologia foi aprimorada para o uso em efluente de baixa carga orgânica também. A faixa de eficiência no tratamento varia entre $40 \%$ a $75 \%$ para DQO, sendo muitas vezes necessária a utilização de outro tratamento posterior ao reator (JORDAO; PESSOA, 2017).

Com relação à recuperação energética o reator permite a utilização do lodo, o qual pode ser seco em leito de secagem ou centrífuga e reaproveitado. Contudo, por se tratar de um ambiente anaeróbio e fechado, a produção de biogás dentro do reator favorece sua captura para posterior aproveitamento (JORDAO; PESSOA, 2017), tornando este o principal elemento para recuperação energética. Além disto, é preciso analisar as melhores formas de aproveitamento do biogás através da cogeração de energia e calor, para otimizar ainda mais seu aproveitamento (LOBATO, 2011).

Estudos analisam a combinação do uso de reatores com lagoas e seus benefícios no que tange a recuperação energética e pegada carbono (CORNEJO; ZHANG; MIHELCIC, 2013).

Comparado com o tratamento aeróbio, existem diversos benefícios apresentados pelos reatores, como o menor consumo de energia elétrica, menor espaço necessário para implantação, recuperação de energia através da produção de metano, baixa produção de lodo e o efluente tratado conserva os nutrientes, possibilitando seu uso na agricultura (SPERLING; LEMOS CHERNICHARO, 2005; WEI, WEI et al., 2017). Desta forma, os reatores são mais propícios para recuperação energética do efluente doméstico, seja pelo lodo, como pelo biogás (LOPES, 2018). 
Além das tecnologias convencionais, os Biorreatores de Membrana (BRM) tem sido cada vez mais utilizados por apresentarem certas vantagens. Nestes reatores a biomassa fica retida na etapa da filtração o que permite um efluente de melhor qualidade após o tratamento, pois garante a degradação do material orgânico por parte dos microrganismos, e retém os poluentes suspensos também. Os sistemas de BRM permitem a retenção de flocos bacterianos e sólidos suspensos dentro do biorreator (LE-CLECH; CHEN; FANE, 2006). Assim como os retores UASB, estes também demandam menor espaço para implantação, menor volume, menor consumo energético e tem menor geração de lodo. Para a utilização destas tecnologias são utilizadas também procedimentos como pré filtração do esgoto com membranas filtrantes dinâmicas ou não, e osmose reversa, por exemplo, para a concentração do efluente.

\section{Biorreator de membrana}

No caso dos biorreatores de membrana, estes podem ser aeróbios ou anaeróbios. O Biorreator de Membrana Anaeróbio (BRAnM) é um método novo que tem aparecido em diversos estudos. Estes biorreatores se utilizam de membranas, as quais servem como barreira física para sólidos em suspensão e microorganismos, substituindo a clarificação no tratamento de esgoto convencional. Desta forma, o lodo ativado é introduzido por baixo dos módulos de membrana submersos para gerar um padrão de fluxo. Após a passagem pela membrana, a água flui por meio de uma bomba que cria um vácuo no interior da fibra. $\mathrm{O}$ lodo ativado concentrado permanece no tanque de membrana, sendo reciclado de volta para o processo biológico.

Por se tratar de uma tecnologia relativamente nova no mercado, tem um custo elevado de implantação e operação, pois os custos das membranas são proporcionais ao volume a ser tratado, diferente de tecnologias tradicionais que tem redução de gastos com escala. Contudo, este custo tem se tornadao cada vez mais competitivos, principalmente para pequenos sistemas (PORTAL TRATAMENTO DE ÁGUA, 2009).

Dentre as principais vantagens do BRAnM está a necessidade de pequenas áreas, produção de um efluente de boa qualidade, boa capacidade para a remoção de material orgânico e menor produção de lodo. Segundo Song et al. (2018) nos Biorreatores existe ainda a opção de se utilizar o fluxo convencial e fluxo tangencial, que influencia no tratamento. Outra tecnologia são Biorreatores de Membrana Anaeróbia submersa, que depende das condições de design e operação para favorecer a geração de energia (PRETEL et al., 2015).

Com relação às membranas, estas podem ser de ultrafiltração e microfiltração, fator de define o tamanho dos poros, que influencia diretamente na qualidade do efluente gerado, bem 
como a configuração do módulo da membrana, se é externa ou submersa, a velocidade do fluxo ou vazão, e as características do afluente. Os poros para ultrafiltração variam entre 0,05 a 0,4 $\mu \mathrm{m}$, e para microfiltração, 5, 10 e $25 \mu \mathrm{m}$ (CIRNE et al., 2019; LE-CLECH; CHEN; FANE, 2006).

A principal dificuldade do BRAnM é a colmatação (fouling) das membranas no momento da passagem do efluente, que afeta a vida útil e o consumo energético da planta de tratamento. As inscrustrações na membrana, aumentam a resistência na filtração, reduzindo a vida útil da membrana, impondo um limite baixo de tempo de retenção e temperatura, complicações com recuperação do metano dissolvido, e opções de remoção de nutrientes (SMITH et al., 2012b; WANG, YONG-PENG et al., 2012). Para mitigar este problema, tem sido utilizado biorreatores com membrana dinâmica ou membrana de filtração de cerâmica, de formar a filtrar o efluente antes de entrar em contrato com a membrana de tratamento biológico (CIRNE et al., 2019; JEONG; HERMANOWICZ; PARK, 2017).

Existe ainda a possibilidade de utilizar reatores em conjunto com a membrana filtrante, ou combinado com osmose reversa, onde o reator permite retenção de parte significativa da biomassa no biorreator, concentrando o efluente, reduzindo o potencial de obstrução da membrana (SMITH et al., 2012a; WEI, CHUN-HAI et al., 2014) e reduz a quantidade de energia necessária para o pré-aquecimento do efluente (CHEN, LIN et al., 2014).

Com esta integração pode ser atingida maior remoção de matéria orgânica e recuperação de nutrientes (SONG et al., 2018). Além disto, este tipo de sistema tem significativa vantagem em relação aos sistemas aerados, considerando a performance da filtração e o uso energético (MEZOHEGYI; BILAD; VANKELECOM, 2012). Segundo Smith et al. (2014), em determinadas condições e melhorias o BRAnM apresenta um percentual significativo de recuperação energética em relação aos tratamentos convencionais, como de lodos ativados.

\section{Células Combustíveis Microbianas (MFCs)}

Além dos Biorreatores, existem também as células combustíveis microbianas que utilizam micróbios como biocatalizadores de recuperação energética de matéria orgânica, transformando em energia elétrica. Esse sistema tem sido estudado com a possibilidade de ser autossuficiente ou neutro energeticamente, dependendo das condições operacionais, que podem influenciar significativamente os micróbios. Esta tecnologia tem se demonstrado competitiva em relação as tecnologias convencionais de tratamento de esgoto, como lodo ativado (ISHII et al., 2013). 
As células funcionam convertendo energia química em energia elétrica, onde Hiegemann et al. (2016) em seu projeto piloto, demonstra que a economia e produção de energia são maiores do que as perdas na produção de biogás. Nos últimos tempos aumentou-se o interesse em Células Combustíveis Microbianas (MFC) devido a geração de energia e por se tratar de uma forma sustentável de tratamento de efluentes. O principal limitador da aplicação desta tecnologia em larga escala é a redução da capacidade de tratamento, como a capacidade de tamponamento, baixa condutividade e baixa biodegradabilidade (LIANG et al., 2018).

Oon et al. (2016) obteve bons resultados em seu estudo utilizando MFC construída com fluxo ascendente, onde teve uma melhor performance na nitrificação e na remoção da matéria orgânica, e a densidade energética máxima aumentou significativamente com o aumento da carga orgânica. Tem se discutido também sobre o uso de MFC integradas com a construção de terrenos alagadiços como pantanais, uso de macrófitas e aumento da aeração, para um melhor desempenho na remoção de nutrientes, além de favorecer a geração de energia (OON et al. 2017).

Assim como nos Biorreatores, também é possível combinar Células Combustíveis Microbianas e osmose reversa com potencial significativo de aumentar a eficiência energética de processos de tratamento de esgoto. No estudo de Liu et al., (2017) utilizando esgoto com baixa carga orgânica com as tecnologias de acidificação anaeróbia, células combustíveis e osmose reversa, se percebeu a viabilidade da união destas tecnologias, proporcionando geração estável de energia e maior densidade energética.

Outra alternativa, é a possibilidade de unir MFC com Bioreator Tubular de Membrana (TMBR), o qual favorece a mitigação da compactação da membrana significativamente (ZHOU et al., 2015) e o custo de ambas as tecnologias, sendo atrativo economicamente, auxiliando na redução do consumo de energia, melhoria do tratamento do efluente e geração de energia (WANG, JIE et al., 2013).

\section{Outras tecnologias}

Além das tecnologias acima citadas, existem outras alternativas comentadas a seguir. Um exemplo são os sistemas Microbianos Eletroquímicos, também conhecido como Célula de Eletrólise Microbiana (MEC) para esgoto com baixa carga, obtendo baixa produção de lodo e com boa eficiência energética, que podem tornar a ETE autossuficiente (KHAN et al., 2017; VILLANO et al., 2013). Nesta tecnologia os microorganismos são capazes de oxidar a matéria orgânica e gerar uma corrente elétrica, a qual pode ser utilizada para geração de energia ou para 
produção de produtos químicos. Esta tecnologia explora a cooperação biológica e eletroquímica, unindo a digestão anaeróbia com o sistema microbiano eletroquímico, mas necessita de mais estudos para analisar a complexidade da operação do sistema (WANG et al., 2015).

Outro exemplo, são tecnologias que envolvem lagoas de algas com elevada carga (HRAP) que podem ser utilizadas para recuperação de recursos. No estudo de Arashiro et al. (2018) o uso do HRAP ao invés do lodo ativado pode tornar o sistema mais sustentável e viável economicamente, considerando a produção de biofertilizante. É necessário analisar o valor agregado do biofertilizante comparado com a energia gerada atráves da cogeração com biogás. HRAP é uma alternativa sustentável e viável para tratamento de esgoto em pequenas comunidades, especialmente em regiões de clima quente, favorencendo a economia circular.

\section{Co-digestão}

A co-digestão tem sido mencionada regularmente como solução para melhoria da eficiência da produção de biogás para resíduos. O uso da codigestão tem sido considerado com substratos biodegradáveis que favoreçam a eficiência energética das plantas, e que comprovadamente aumentem a geração de energia pelos digestores, onde ocorra geração de mais metano, do que com o processamento de cada substrato separadamente (DI MARIA; MICALE; CONTINI, 2016). No caso dos efluentes domésticos, o ideal é a junção do lodo do esgoto proveniente do tratamento, com o resíduo sólido orgânico de outra fonte. Para isto, é necessária a adequação da tecnologia para um desempenho eficiente no tratamento do conjunto de resíduos.

Em casos onde o lodo passa a ser centrifugado antes da disposição, pode ser ainda melhor sua eficiência para a geração de biogás junto aos resíduos sólidos. Di Maria, Micale, Contini (2016) em seu estudo testaram a co-digestão de lodo de esgoto com resíduos de frutas e vegetais em diferentes taxas de cargas orgânicas. Neste caso, a codigestão aumentou de forma significativa o volume de produção de biogás $\left(140 \mathrm{NL} / \mathrm{m}^{3}\right.$.dia para $900 \mathrm{NL} / \mathrm{m}^{3}$.dia $)$ e em certas taxas, ocasionou também a redução de Tempo de Detenção Hidráulico e reduziu o percentual de degradação de sólidos voláteis. Desta forma, se trata de uma solução que pode otimizar os recursos das estações de tratamento de esgoto atuais e melhorar a geração de energia, aumentando a carga orgânica e reduzindo o tempo de detenção hidráulica. Observou-se também que resíduos de frutas e vegetais são mais favoráveis para a co-digestão com lodo de esgoto, e 
podem utilizar as instalações já existentes, mantendo a operação estável no digestor (DI MARIA et al., 2015)

Segundo a ABiogás existem 15 plantas de codigestão de resíduos e efluentes gerando energia elétrica, térmica e biometano, no país atualmente (ABIOGAS, 2020).

\section{Compostagem}

Uma das formas de recuperação material usadas com frequência é a utilização do lodo de tratamento de esgoto para uso na agricultura e o uso do efluente tratado dentro da planta, para diversos funcionalidades.

Pela compostagem é possível produzir fertilizantes minerais e utilizar na recuperação de solos degradados. Contudo, a emissão de gases do efeito estufa ainda persistem (DI MARIA; MICALE; CONTINI, 2016). O estudo de Liu et al. (2013) analisou o ciclo de vida e estratégias de disposição de lodo, envolvendo aterro, mono incineração, co-incineração, produção de tijolos, produção de cimento e fertilizante para uso em áreas urbanas, através da compostagem. Pelo estudo recomenda-se o uso da compostagem, com a diminuição da quantidade de água no lodo de $80 \%$ para $60 \%$, para melhor aproveitamento. É possível ainda, através de compostagem térmica, utilizar o lodo como composto (GROBELAK; GROSSER; KAMIZELA, 2019).

A disposição do lodo de ETE no solo também é uma alternativa, principalmente em ETEs de pequeno e médio porte, tendo em vista que em pequenas instalações o lodo, em geral, não contém a quantidade adequada de água para ser utilizado em tecnologias de recuperação energética. Por esta razão, devem ser pensadas alternativas, como o uso do esgoto doméstico e lodo para produção de biomassa e fertilizantes (GROBELAK; GROSSER; KAMIZELA, 2019). Contudo, é importante lembrar que, no caso do uso do lodo, é necessário garantir que suas características estejam de acordo com a Resolução CONAMA No 430/2011 que dispõe sobre sua qualidade para usos agrícolas, que altera a Resolução CONAMA No 375/2006.

Com base nas alternativas tecnológicas disponíveis e apresentadas, é necessária uma análise da conjuntura para melhor entendimento das barreiras para sua implementação, relacionando o tratamento e a recuperação energética do esgoto sanitário. Apesar do elevado custo de investimento, com o passar do tempo existe uma tendência das tecnologias obterem um potencial de mercado mais favorável (RESCH et al., 2008). Segundo Resch et al., (2008) e Mariani (2018) os potenciais que devem ser analisados para o uso de tecnologias são: 
- Teórico - relacionado ao potencial termodinâmico calculado e o limite máximo de energia a ser aproveitada de um determinado recurso;

- Técnico - relacionado às condições das limitações dos equipamentos em uso, perdas do processo e barreiras socioambientais;

- Econômico - relacionado ao potencial técnico que é economicamente rentável; e

- Realizável - que é a combinação dos outros potenciais assumindo-se a superação das barreiras existentes.

Estes potenciais podem ser representados ao longo do tempo, como na Figura 4, demonstrando que eles podem se tornar mais viáveis ao longo do tempo.

Figura 4 - Categorias dos tipos de potencial em relação à geração de energia ao longo do tempo.

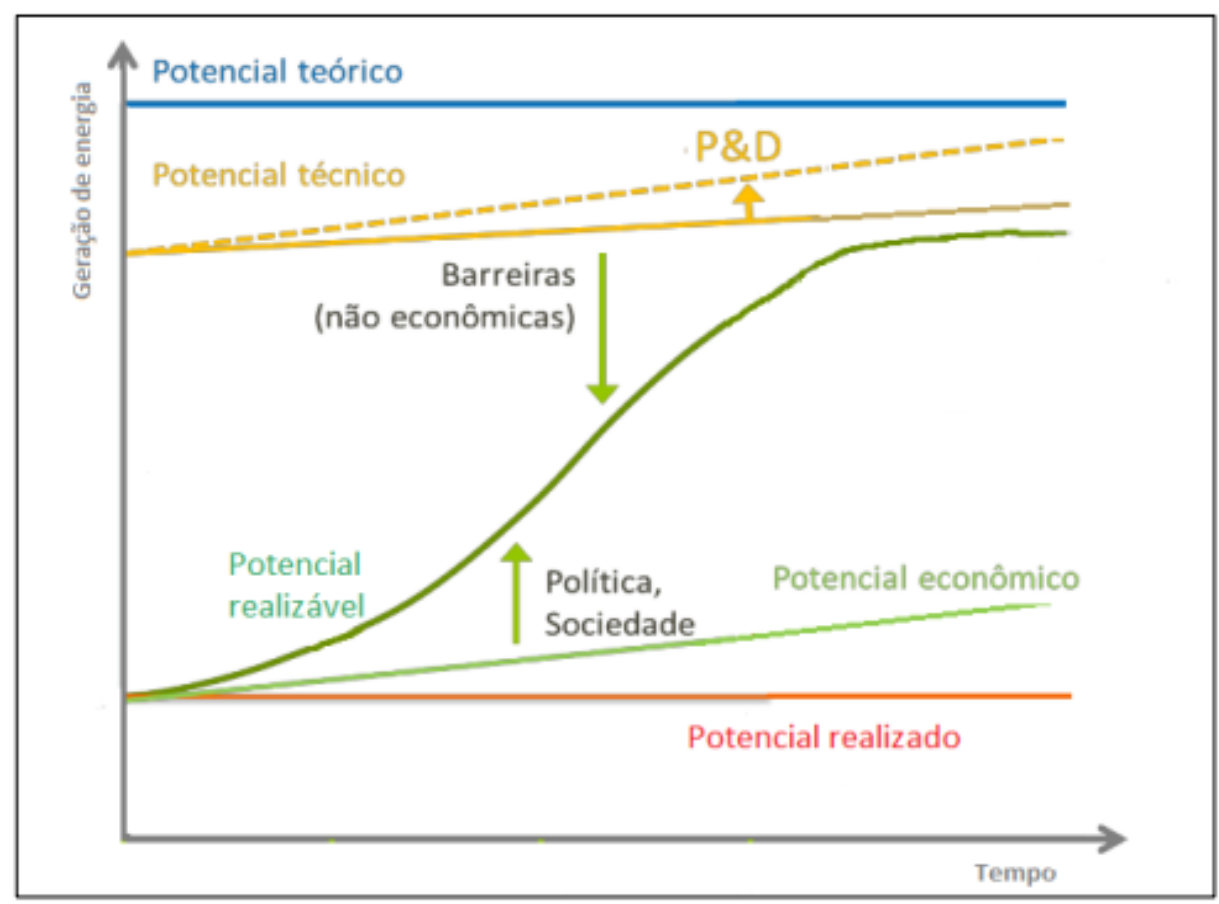

Fonte: MARIANI, 2018.

Tendo em vista que uma das principais barreiras para a construção e operação das plantas de tratamento de efluente é a econômica, a recuperação energética do efluente, permite a redução de custos operacionais com a demanda de energia; e podem ainda ser feitas ações para economia de energia e melhoria na eficiência energética da planta. Em conjunto, estas ações podem inclusive tornar a ETE autossuficiente energeticamente (BREACH, 2018; MEERBURG 
et al., 2015; TANG et al., 2019) . Considerando, que em média, entre $25 \%$ a $40 \%$ dos custos operacionais das ETEs estão relacionados ao consumo de energia, tanto para processos aeróbios quanto anaeróbios (GU; XU; LIU, 2017), alcançar a autossuficiência energética nestas plantas representa um ganho significativo na redução dos custos de operação.

Além do elevado consumo de energia elétrica, as ETEs também podem ser emissoras de Gases do Efeito Estufa (GEE) quando utilizam combustíveis fósseis. Desta forma, além dos benefícios da geração de energia, a recuperação energética permite ainda a redução de emissão de GEEs e possibilitam o uso de crédito de carbono (BREACH, 2018).

Com relação às ações para economia de energia e melhoria na eficiência energética da planta de tratamento de efluentes, é importante destacar que o uso de energia elétrica se torna mais intensivo no tratamento secundário, onde ocorre a maior parte da remoção da matéria orgânica do efluente, principalmente quando utilizados processos aeróbios, como de lagoas de estabilização (LANE; DE HAAS; LANT, 2015).

A maioria das plantas autossuficientes energeticamente utiliza geração de biogás a partir da digestão anaeróbia para aquecimento do reator e para geração de eletricidade (GU; XU; LIU, 2017). Em países de clima temperado, como do hemisfério norte, por exemplo, o uso do biogás é voltado para geração de energia térmica, utilizada para aquecer o efluente, contribuir para melhor tratamento da efluente e melhorar a produção de biogás (DÜRRENMATT; WANNER, 2014). A recuperação térmica, desta forma contribui para a redução de custo com o aquecimento do efluente, para se atingir a temperatura mesofílica (WEI, CHUN-HAI et al., 2014), favorecendo assim a redução de custos operacionais, otimizando o tratamento do efluente e aumentando a produção de biogás.

Em plantas que utilizam o tratamento aeróbio, por sua vez, é possível a incineração do lodo para produção de energia térmica. Quanto maior o volume de lodo é possível aumentar a transformação do lodo primário em geração de eletricidade (LARSEN, 2015). Em suma, tecnologias aeróbias tem uma produção significativa de lodo que pode ser incinerado e transformado em energia elétrica ou térmica, enquanto que tecnologias anaeróbias, apresentam menor quantidade de lodo, contudo tem a capacidade de capturar maior quantidade de biogás, o qual também pode ser convertido em energia térmica ou elétrica, a depender de variáveis externas à tecnologia e à demanda energética. Por esta razão cada solução tem suas particularidades quanto à eficiência energética (BREACH, 2018) e quanto ao uso final. 


\subsection{Viabilidade do uso da recuperação energética}

Para avaliação sobre as diversas variáveis que podem contribuir ou não para a viabilidade de projetos, é necessária uma abordagem holística, considerando aspectos técnicos, territoriais, econômicos, sociais e ambientais, de forma integrada, no momento da avaliação sobre o investimento no tratamento de esgoto doméstico com recuperação energética (BREACH, 2018).

Muitos estudos têm buscado entender quais são os principais parâmetros que influenciam a implantação de plantas para recuperação de recursos. A análise das condições locais para o entendimento sobre a viabilidade do projeto envolve parâmetros como: densidade populacional, topografia, localização geográfica, opções de recuperação de recursos, condições do esgoto, características do efluente, recursos rurais e urbanos, disponibilidade de terreno, e demanda pelo material recuperado no tratamento, por exemplo (CASHMAN et al., 2018; KERSTENS; LEUSBROCK; ZEEMAN, 2015).

Segundo Cashman et al., (2018) os impactos ambientais da planta reduzem com o aumento da densidade populacional, contudo, a densidade populacional não foi o indicador mais relevante para impactar o meio ambiente. Neste caso, aspectos como a temperatura do efluente e clima tiveram mais influência que o uso do solo, na viabilidade da planta, por exemplo. Com relação às características do efluente, este influencia o tamanho da planta e seu consumo energético (BREACH, 2018), e consequentemente seu custo operacional.

Cornejo et. al. (2013) em seu estudo realizou uma análise sobre energia incorporada, pegada de carbono e potencial de eutrofização de tecnologias de tratamento de esgoto. No estudo identificou que a necessidade de implantar infraestrutura para coleta de esgoto tem influência significativa na adoção de soluções sustentáveis de saneamento. Além disto, verificou que a preocupação com o saneamento, falta de água, mudanças climáticas e deteriorização de recursos, sobressaem em relação ao aproveitamento de recursos em plantas de tratamento, em relação à aceitação da população.

Tendo em vista que a viabilidade da planta perpassa diversos aspectos, como os mencionados acima, optou-se por elencar os principais fatores e os parâmetros atrelados a eles, para melhor entendimento sobre a sua relevância, frente à viabilidade da planta de recuperação energértica de efluentes domésticos. 


\section{Análise Técnica}

No caso da análise técnica é importante ter conhecimento de parâmetros em duas vertentes principais, com relação ao tratamento e à recuperação energética. No que se refere ao tratamento do efluente, deve-se considerar parâmetros como: vazão afluente do esgoto doméstico, características do esgoto doméstico na entrada do tratamento, infraestrutura de coleta e tratamento. Com relação à recuperação energética, importante avaliar as características do substrato, o armazenamento ou queima de biogás, necessidade energética in loco, entre outras informações. Vale salientar que o dimensionamento das estruturas da Estação de Tratamento de Esgoto (ETE) se dá a partir do valor da vazão a ser recebida e a carga orgânica. E estes aspectos influenciam o tempo de detenção hidráulico do efluente. Segundo SANEPAR (2017), o porte das plantas é determinada pela sua vazão afluente, conforme apresentado na Tabela 8.

Tabela 8 - Definição do porte da ETE pela vazão afluente.

\begin{tabular}{cc}
\hline Porte & Vazão (L/s) \\
\hline Pequeno & $<60$ \\
\hline Médio & entre 60 a 200 \\
\hline Grande & $>200$ \\
\hline \multicolumn{2}{c}{ Fonte: Adaptado de SANEPAR (2017). }
\end{tabular}

Percebe-se também que as características do substrato são fundamentais para a análise técnica do projeto tanto no que se refere ao tratamento, quanto à recuperação energética. De maneira geral, os principais parâmetros para o esgoto sanitário sob este aspecto, são: Demanda Química de Oxigênio (DQO) (mg/L), indicador da quantidade de compostos orgânicos em um líquido, o indicador de coliformes fecais $(\mathrm{CF} / 100 \mathrm{~mL})$ (DE QUEIROZ; PAES; FERNANDES, 2018; MCCARTY; BAE; KIM, 2011), e Sólidos. Outros estudos elecam outros aspectos como: composição físico-química (mais material orgânico significa mais metano e biogás), relação Carbono Nitrogênio (ideal entre 20:1 a 30:1), teor de água (ideal entre 60\% a 90\% do peso total), temperatura (entre $32^{\circ}$ a $37^{\circ} \mathrm{C}$ para bactérias mesofilicas e $50^{\circ}$ a $60^{\circ}$ bactérias termofílicas), $\mathrm{pH}$ (próximo a 7 para tratamento em reatores anaeróbios), (MO; ZHANG, 2012; PECORA, 2006; PRETEL et al., 2013), demanda de energia para aquecimento ou resfriamento do efluente (DÜRRENMATT; WANNER, 2014).

A partir de parâmetros como vazão, DQO e sólidos do efluente antes e após o tratamento, é possível determinar a eficiência no tratamento e a vazão estimada de biogás gerado. Com estas definições é possível fazer uma projeção da produção de biogás e analisar a viabilidade 
técnica do projeto. Segundo Pecora (2006), para que a produção de biogás seja regular em um período de 24 horas, a ETE deverá atender, no mínimo, uma população de 10 mil habitantes, com capacidade de geração de $5.544 \mathrm{kWh} /$ mês. A energia que pode ser economizada com a recuperação de nutrientes e sua reciclagem depende significativamente da carga de nutrientes do esgoto (MO; ZHANG, 2012).

Dentre as dificuldades que se apresentam na geração do biogás estão: a influência do dióxido de carbono, dos bicarbonatos e carbonatos sobre o $\mathrm{pH}$ do meio aquoso e sua capacidade ácido básica; a possível insolubilização dos metais sob a forma de sulfetos muito pouco solúveis; a complexação do cobre pelos íons de amônia; e a emissão eventual de maus odores. Além disto, a presença de substâncias como água e dióxido de carbono no gás prejudica a queima do metano, tornando-o menos eficiente (PECORA, 2006).

Ainda a nível técnico, após caracterizado o esgoto doméstico, é necessário definir a tecnologia mais adequada para tratamento e recuperação energética. As tecnologias de tratamento podem ser aeróbias, com maior geração de lodo, ou anaeróbias, com foco na produção de biogás. No que tange as tecnologias, os principais aspectos envolvem o tipo de tecnologia e o porte da planta, como melhor detalhado na seção sobre tecnologias. Sobre as tecnologias de recuperação de energia, os principais equipamentos conversores de energia a partir do biogás são as turbinas a gás, turbinas do ciclo Brayton aberto ou com cogeração, microturbinas à gás e motores de combustão interna. Para a conversão energética do biogás, os motores possuem maior eficiência. Já as turbinas a gás possuem maior eficiência global de conversão, quando operadas com cogeração (calor e eletricidade) (COELHO, 2004).

Nos estudos, variáveis como carga orgânica, espaço entre eletrodos e a conexão do circuito, influenciam de forma significativa a performance do tratamento e da produção de biogás (OON et al., 2017). No estudo de Xiao et al., (2014) foi analisado um parâmetro chamado de Recuperação de Energia Normalizada (NER), o qual apresenta a performance energética. Segundo o estudo, os principais fatores que influenciam a recuperação energética é a concentração do substrato e o Tempo de Retenção Hidráulico (TRH) (XIAO et al., 2014). Além disto, diversos artigos mencionam que o aumento da carga orgânica tem impacto significativo na performance das ETEs e principalmente na geração de biogás.

\section{Análise Territorial}

Com relação ao território, os parâmetros estão diretamente relacionados à localização geográfica da planta e à infraestrutura existente. A configuração do uso das tecnologias depende 
significativamente da sua localização geográfica, tanto para tratamento como para a recuperação energética de biogás, lodo e nutrientes. Regiões tropicais são mais favoráveis para reatores anaeróbios, por exemplo, do que as regiões temperadas, pois é necessário considerar aspectos como a temperatura do ambiente para o efluente, a qual interfere na metanogênese e por conseguinte na produção de biogás (GAO et al., 2015). O uso de microalgas para tratamento, por exemplo, só consegue ser utilizado durante o ano todo em regiões tropicais. Locais onde o esgoto apresenta baixas temperaturas, o lodo ativado tende a ser a opção mais viável (KHIEWWIJIT et al., 2018).

Com relação à disponibilidade de infraestrutura, para o melhor desempenho da recuperação energética, é necessário considerar a área ocupada pela ETE (depende do porte), recursos e infraestrutura disponíveis para implantação e operação, capacidade e conhecimento técnico disponível na região, potência instalada, consumo de energia, infraestrutura próxima para disposição de lodo, remoção e aproveitamento de nutrientes, complexidade operacional, vida útil (COELHO; VELAZQUEZ; SILVA, 2006), distância da fonte de efluentes, entre outros.

\section{Análise Econômica}

No que tange os parâmetros econômicos, é fundamental que os custos de implementação, operação e custos com disposição de resíduos sejam menores que a receita com a geração de energia, de forma a alcançar um menor tempo de retorno (payback) e o investimento se tornar viável (FLORES-ALSINA et al., 2014b; DIAS; ET AL, 2013; ESPERANCINI et al., 2007). Aspectos como a eficiência da tecnologia para conversão dos resíduos em energia, o preço do gás e da energia elétrica, também influenciam a análise (AYMERICH et al., 2015). Além disto, é necessária que a avaliação seja feita localmente para que seja mais precisa, principalmente no caso de plantas de tratamento de efluentes descentralizadas (LUMLEY et al., 2014).

Lam et al., (2017) utiliza a curva de custo como ferramenta para analisar o aproveitamento do biogás em plantas de tratamento de esgoto, as quais podem favorecer os sistemas urbanos de água e no planejamento do uso da água, para economia de energia e redução de emissão de gases (LAM; KENWAY; LANT, 2017). Segundo Cashman et al. (2018), no caso do custo da planta, este foi pouco influenciado pelas questões regionais e requisitos operacionais de energia, e mais influenciado pela escala do reator, com economias de escala para Biorreatores de Membrana de larga escala, e dependente dos requisitos de capital, materiais e serviços.

Com a compilação dos dados de custos e receitas é necessário analisar os indicadores de investimento conforme a literatura, quais sejam: Valor Presente Líquido (VPL), Taxa Interna 
de Retorno (TIR) e Período de Recuperação do Capital (payback) (CASAROTTO FILHO; KOPITTKE, 2007; NOGUEIRA, 2009). Conforme estudos já realizados notou-se que plantas com maior quantidade de resíduos tendem a ser viáveis, devido à economia de escala, pois tem condições de produzir mais biogás, e consequentemente receita, a partir da geração de energia (CERVI, 2009).

\section{Análise Social}

Os parâmetros sociais estão relacionados às condições a que está submetida a população que será atendida pela ETE, no sentido de analisar os impactos positivos e negativos da sua implementação. Além disto, é importante também entender a relação entre os fatores que influenciam a adoção e aceitação social de uma solução de tratamento de efluente com recuperação energética por parte da população, e a garantia do seu uso e desempenho, para que o recurso investido não seja perdido com o abandono das instalações, devido a aspectos como ceticismo em relação à funcionalidade da tecnologia, falta de substrato suficiente, entre outros aspectos. A partir desta análise é possível propor ações direcionadas à população para elevar o nível de aceitação do empreendimento (PROUTY; MOHEBBI; ZHANG, 2018).

Segundo Papa et al. (2017), em seu estudo, o resultado de entrevistas mostra que as principais forças motrizes de sistemas de recuperação energética a partir de resíduos são: confiança técnica, viabilidade econômica e aceitação política e social. Esses aspectos são fundamentais para facilitar a dispersão do uso da recuperação de recursos, que ainda é incipiente, já que atualmente, mais de metade das ETEs não realizam nenhum tipo de recuperação.

\section{Análise Ambiental}

Os parâmetros ambientais abrangem principalmente a emissão de GEEs, uso intensivo de energia elétrica que possui impactos ambientais indiretos, e geração de resíduos sem descarte adequado, como pode ser o caso do lodo do tratamento do esgoto (CORNEJO; ZHANG; MIHELCIC, 2013; LANE; DE HAAS; LANT, 2015). Muitos estudos utilizam a Análise de Ciclo de Vida (ACV) para analisar os impactos ambientais positivos e negativos de processos como a recuperação energética a partir de resíduos, principalmente para a comparação de tecnologias, tanto com relação à construção e a operação da planta. Neste último caso, predomina o impacto do consumo intensivo de energia e a depleção dos materiais que são 
utilizados no tratamento, que ao serem lançados junto ao efluente podem causar eutrofização do corpo hídrico ou ecossistema receptor (WANG, XU et al., 2012). O uso de produtos químicos, inclusive, é mais intensivo na remoção de nutrientes como o Fósforo. Contudo, estes nutrientes extraídos podem ter um impacto positivo com o uso como fertilizantes na agricultura (FOLEY et al., 2010).

Chen (2013) em seu estudo sobre emissão de GEE, apresenta que o uso do biogás em conjunto com as soluções do lodo, podem superar a demanda de energia para gerenciamento e operação de ETEs e reduzir emissões, com as combinações de uso do biogás para gás de cozinha, e o lodo como fertilizante, incinerado ou com a disposição em aterro. Porém, o uso do biogás tem impacto mais significativo, e é o fator mais importante na geração de energia e aproveitamento energético, do que o uso do lodo (CHEN; CHEN, 2013). A combinação das diversas utilidades entre os produtos gerados a partir do biogás e do lodo definem o desempenho ambiental, considerando as emissões de gases do efeito estufa, e o balanço energético da ETE.

Muga e Mihelcic (2008) após estudo sobre os aspectos ambientais, sociais e econômicos da comparação de tecnologias de tratamento de efluentes afirmam que é necessária ainda uma análise geográfica, considerando os dados demográficos para determinar a sustentabilidade do sistema de tratamento de efluentes. Isto reforça a necessidade de abordagens holísticas com relação ao tema (KHIEWWIJIT et al., 2018).

Com este panorama dos principais aspectos que podem influenciar o uso da recuperação energética a partir de efluentes domésticos, é possível ter uma dimensão da análise holística necessária para entender a viabilidade para uso destas tecnologias. As políticas públicas em prol deste tema precisam considerar os aspectos técnicos, econômicos, territoriais, sociais e ambientais, para que tenham sucesso no desenho de ações para o setor. É necessário ainda que seja aprofundado o estudo das principais características advindas destes aspectos acima mencionados, e o seu peso na definição sobre a implementação destas tecnologias nos municípios do país.

\subsection{Discussão de resultados revisão bibliográfica}

Em resumo, o cenário deficitário de esgotamento sanitário está presente não apenas no Brasil, como no mundo, e a expansão do uso da recuperação energética, com vistas a transformar as plantas de Tratamento de Efluentes em plantas de Recuperação de Recursos tem aumentado com o passar do tempo. No Brasil, são 15 ETEs mapeadas que já fazem uso destas 
tecnologias, e recentemente houve a sinalização de políticas sendo criadas para este setor, como a Frente Brasil de Recuperação Energética (FBRER), demonstrando uma perspectiva de ampliação e avanço desta temática no país.

Com relação às tecnologias, existe um conjunto de soluções promissoras para recuperação energética de efluentes domésticos que servem como alternativas para viabilizar a implantação e operação de mais estações de tratamento de efluentes no país, de acordo com a realidade de cada local. No Brasil, a predominância das tecnologias de lodos ativados, lagoas e reatores já possibilitam o direcionamento de estudos para adaptação destas plantas para uso da recuperação energética.

A partir do diagnóstico de cada situação e o levantamento das tecnologias disponíveis, é possível analisar os aspectos relevantes, a nível técnico, econômico, territorial, social e ambiental, para viabilizar o uso destas soluções de forma adequada em cada local ao longo do tempo, e trazer benefícios e incentivos para o aumento do percentual de coleta e tratamento dos efluentes domésticos no Brasil, assim como aumentar o percentual de energia renovável gerado no país.

4. Estado da arte dos efluentes domésticos no Maranhão

\subsection{Metodologia de estudo de caso}

Visando alcançar o objetivo de caracterizar a gestão do efluente doméstico e realizar o diagnóstico da situação do esgotamento sanitário no Maranhão, foi utilizado o método do estudo de caso. Este método busca auxiliar na tomada de decisões por meio da análise de dados da unidade de estudo. Para isto, é necessário elaborar uma pergunta de pesquisa, a qual servirá como guia para todo o desenvolvimento do conteúdo do trabalho (YIN, 2014). Neste caso, a pergunta que norteia o estudo é: Quais são as oportunidades e dificuldades para recuperação energética a partir de efluentes domésticos no Estado do Maranhão?

Para levantamento das informações para o estudo de caso, foram realizadas entrevistas conduzidas através do método de Snowball sampling, também conhecido como amostragem por referência em cadeia, não probabilística, por meio da qual são selecionados atores para aquisição de informações e estes indicam outros atores. Logo, esta técnica se baseia na coleta de informações primárias a partir de entrevistas, nas quais são indicadas outras pessoas potenciais que possam fornecer mais dados primários, gerando assim referências em cadeia (GOODMAN, 1961; SANCHES-PEREIRA et al., 2017). Neste estudo, o método foi utilizado 
para encontrar os representantes ou responsáveis pela operação dos 217 sistemas de abastecimento de água e esgotamento sanitário de todos os municípios do Maranhão para a realização do diagnóstico da situação. Os representantes também auxiliaram na coleta de dados de diversas fontes, para obter dados qualitativos e quantitativos presentes em documentos oficiais e extra-oficiais das instituições. Na Figura 5 é apresentado o diagrama das entrevistas realizadas utilizando o método do Snowball sampling.

Figura 5 - Diagrama de entrevistas utilizando Snowball sampling.

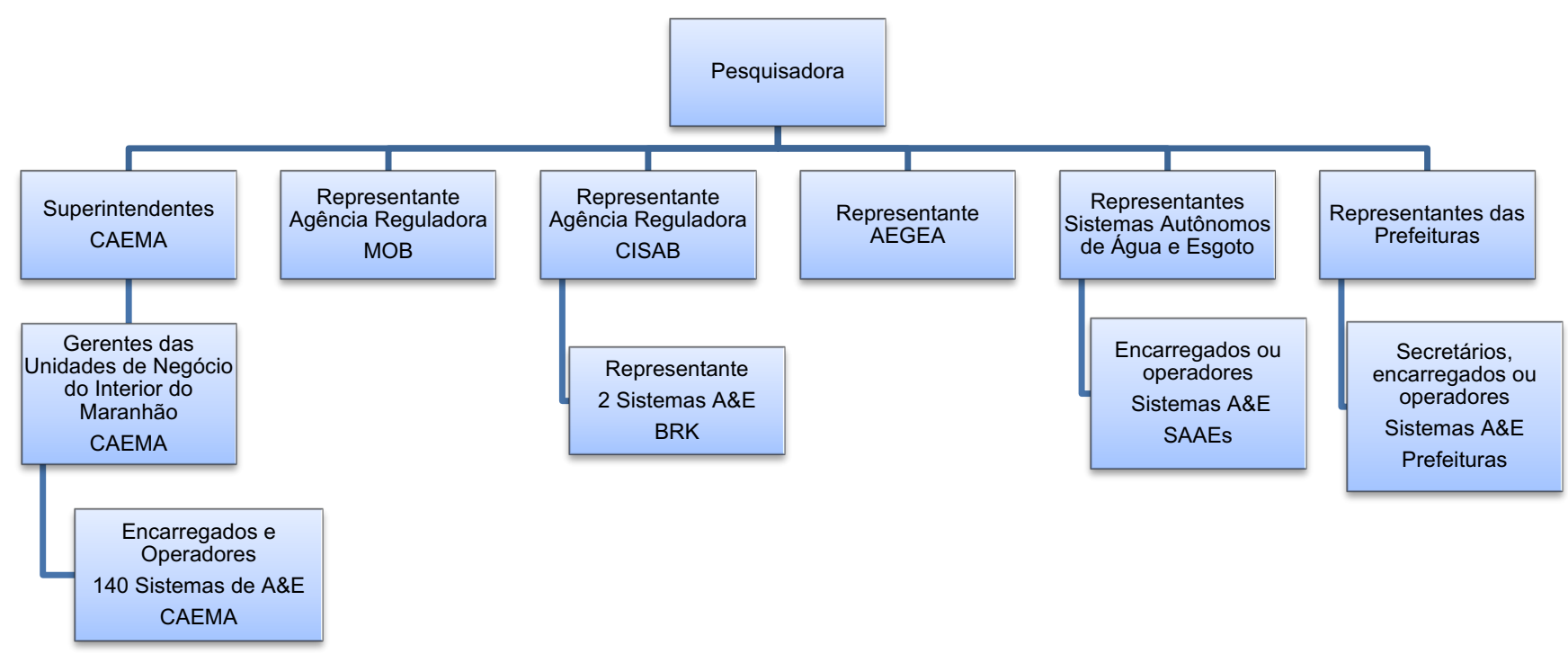

Fonte: Elaborado pela própria autora.

As entrevistas tiveram como foco o diagnóstico sobre a situação do esgotamento sanitário nos 217 municípios para se obter um panorama geral do Estado do Maranhão, e se baseou em questões semi estruturadas, as quais não precisavam ser respondidas em ordem e se referiam a dados quantitativos e qualitativos (RUNESON; HÖST, 2009). As entrevistas foram realizadas por e-mail, telefone e Whatsapp. Além disto, foi estruturado um banco de dados com o registro das respostas adquiridas nas entrevistas e informações sobre os responsáveis pelos sistemas, que responderam ao questionário. O questionário segue no Apêndice $\mathrm{B}$ da pesquisa.

Para a aquisição de informações sobre o Estado do Maranhão, o formato da gestão atual, os parâmetros do esgoto doméstico no Estado, entre outros, os dados foram coletados nas seguintes fontes:

- Base de Dados: CAEMA, IBGE, SNIS, ANA, NUGEO;

- Análises dos parâmetros do esgoto das ETEs; 
- Entrevistas com colaboradores da CAEMA, BRK, e outras instituições;

- Banco de dados do PROBIOGÁs;

- Portal CIBiogás.

Foram consultados em torno de 150 documentos, além dos artigos da revisão bibliográfica, de forma a compor as informações para o estudo de caso e desenvolvimento da metodologia de pesquisa.

Com relação aos dados de saneamento, tendo em vista que o Diagnóstico 2018 do SNIS não possui informações de todos municípios referentes a 2018 e o Atlas do Esgoto da ANA possui informações dos 217 municípios do ano de 2013, as informações que não foram encontradas no SNIS 2018, foram obtidas nos dados da ANA.

De maneira a facilitar a compreensão e visualização da disposição espacial de informações coletadas e entender o estado da arte da coleta e tratamento de esgoto doméstico no Maranhão foi feito o mapeamento das unidades de tratamento de esgoto do Estado, e detalhados os atores envolvidos na gestão destes resíduos. Para isto foi utilizado o software QGIS. Este é um software de georeferenciamento livre, gratuito, que permite o mapeamento de dados e possibilitou a elaboração de mapas temáticos para a dissertação.

\subsection{Caracterização administrativa e gerencial}

Entre os 217 municípios maranhenses, a responsabilidade pelo sistema de abastecimento de água e esgotamento sanitário de cada município está sobre a concessão de diversas instituições, dentre elas estão: Companhia de Saneamento Ambiental do Maranhão (CAEMA); Águas de Timon; BRK Ambiental; Sistemas Autônomos de Água e Esgoto (SAAE); e Prefeituras Municipais. O Apêndice C apresenta o operador do sistema de cada município.

Dentre as entidades responsáveis pela operação do abastecimento de água e esgotamento sanitário nos municípios do Maranhão estão:

- Prefeitura Municipal (PM)

Conforme as responsabilidades definidas pelo Pacto Federativo, onde se determina que Estados e municípios possuam um governo próprio com certa autonomia para assuntos de sua abrangência, é de responsabilidade do município a concessão sobre os serviços de saneamento básico, exceto em casos de regiões metropolitanas (CNM, 2015). 
No caso do Maranhão, existe a Região Metropolitana da Grande São Luís (RMGSL) regida pela Lei Complementar Estadual No 174/2015, composta por 13 municípios, sendo eles: São Luís, São José de Ribamar, Raposa, Paço do Lumiar, Alcântara, Bacabeira, Rosário, Axixá, Santa Rita, Presidente Juscelino, Cachoeira Grande, Morros e Icatu; e a Região Metropolitana do Sudoeste Maranhense (RMSM) regido pela Lei Complementar Estadual $N^{\circ}$ 89/2005, composta por 8 municípios, sendo eles: Imperatriz, João Lisboa, Senador La Rocque, Buritirana, Davinópolis, Governador Edison Lobão, Montes Altos e Ribamar Fiquene (SECID, 2015).

Atualmente, aproximadamente $23,96 \%$ das prefeituras dos municípios maranhenses operam os sistemas de abastecimento de água. Com relação ao esgoto doméstico, $84,33 \%$ das prefeituras são responsáveis pelo esgotamento sanitário de seu município. Quando o serviço de abastecimento de água ou esgotamento sanitário não é prestado pela Prefeitura, ele é concedido para o SAAE, CAEMA ou empresa privada. Com o novo Marco Regulatório do Saneamento as Prefeituras deverão realizar licitações, caso haja mais de uma instituição interessada na concessão do serviço. Com o veto do Art. 16 da Lei No 14.026/2020, o qual prevê um período de transição até 2022 dos Contratos de Programa e Contratos de Concessão, esta mudança já está vigente, e a sociedade aguarda a votação sobre a consolidação do veto ou da continuidade do Art. 16 na Lei. Existem casos ainda em que a Prefeitura opera parcialmente o sistema, e outra instituição opera o restante. Esta situação ocorre comumente entre Prefeitura e CAEMA, em aproximadamente 12 municípios.

- Serviço Autônomo de Água e Esgoto (SAAE)

O Serviço Autônomo de Água e Esgoto (SAAE) é um tipo de autarquia à qual a Prefeitura oferece a concessão dos serviços públicos de saneamento básico. Os SAAEs estão presentes em todo o país, e no Maranhão correspondem a aproximadamente 9,22\% da concessão dos municípios, tanto para água como para esgoto, o que equivale a 21 cidades. A criação dos SAAEs teve origem em programas de saneamento do Ministério da Saúde em parceria com a Fundação Serviços de Saúde Pública (FSESP), entidade que foi fundida à Fundação Nacional de Saúde (FUNASA) (FUNASA, 2001).

- Companhia de Saneamento Ambiental do Maranhão (CAEMA)

A CAEMA é uma companhia em regime de sociedade de economia mista, criada a partir da Lei Estadual 2.653 de 06 de junho de 1966. Atualmente, a Companhia é regida pela Lei 6.404/76 e pela Lei № 13.303/16, que é aplicável às Empresas Estatais. 
A Companhia é vinculada ao Governo do Estado do Maranhão por meio da Secretaria do Estado das Cidades (SECID) e tem como objetivo gerir a política de saneamento básico do Estado do Maranhão e, especialmente, planejar, coordenar, implantar, ampliar, construir e explorar serviços de abastecimento de água e esgotamento sanitário (CAEMA, 2018).

Atualmente, a Companhia possui a maior infraesturura do Estado para operar o Sistema de Abastecimento de Água (SAA) de 140 municípios, representando 61,75\% do contingente total dos municípios a CAEMA. No que se refere ao esgotamento sanitário, a Companhia opera parcialmente em três municípios, que correspondem a 1,38\% dos municípios, contudo, abrangem a Capital e a cidade de Imperatriz, que são as maiores cidades do Estado. Além disto, em 10 municípios, a Companhia opera as ETEs de residenciais, considerando São Luís e Imperatriz. Atualmente, a Companhia é fiscalizada e tem suas tarifas reguladas pela Agência Estadual de Transporte e Mobilidade Urbana e Serviços Públicos (MOB).

\section{- BRK Ambiental}

A BRK Ambiental é uma empresa brasileira privada de saneamento básico, criada em janeiro de 2008 para prestar serviços, principalmente, na área de saneamento básico. A empresa atua com a concessão da operação de sistemas de água e esgoto e atua também por meio de parcerias com empresas públicas e privadas de municípios e estados. A BRK é uma sociedade anônima de capital fechado, a qual integrava a Organização Odebrecht até 2017, e atualmente pertence ao grupo Brookfield, com 70\% de participação da Brookfield e 30\% do Fundo de Investimento do Fundo de Garantia do Tempo de Serviço (FI-FGTS).

A BRK tem atuação em aproximadamente 186 municípios do país, e no Maranhão atua em 2 municípios com abastecimento de água e esgotamento sanitário, São José de Ribamar e Paço Lumiar, compondo 0,9\% do contingente total do Estado (BRK AMBIENTAL, 2017). Os serviços da BRK no Maranhão são físcalizados pelo Consórcio Intermunicipal de Saneamento Básico (CISAB).

- Águas de Timon

A Águas de Timon é uma empresa privada responsável pelos serviços de abastecimento de água e tratamento de esgoto na zona urbana do município de Timon. A empresa pertencente a Aegea Saneamento. Os serviços da Águas de Timon são fiscalizados pela Agência Reguladora de Serviços Públicos Delegados do Município de Timon (AGERT) (ÁGUAS DE TIMON, 2020). 
- Companhia Autônoma de Água Esgoto e Saneamento de Itinga (CAESI)

Criada em 1998, a CAESI é uma autarquia responsável pela operação dos sistemas de abastecimento de água e esgotamento sanitário do município de Itinga com exclusividade para elaborar projetos, operar, manter, conservar e explorar os serviços de saneamento a nível de abastecimento de água e esgotamento sanitário, dentre outros, como entidade autárquica municipal.

- Companhia de Desenvolvimento dos Vales do São Francisco e do Parnaíba (CODEVASF)

A CODESVASF é uma empresa pública, que busca fomentar o desenvolvimento das regiões próximas aos rios São Franciso e Parnaíba e seus afluentes, utilizando os recursos hídricos com ênfase na irrigação. A empresa tem atuação nos estados de Minas Gerais, Bahia, Pernambuco, Alagoas, Distrito Federal, Goiás Sergipe, Piaú e Maranhão. As ações realizadas pela empresa envolvem a aquisição de créditos orçamentários (emendas) para a realização de investimentos que tragam melhores condições de trabalho, mais emprego, mais renda e melhoria na qualidade de vida, abrangendo obras de infraestrutura de saneamento.

No caso do Maranhão, a Superintendência Regional da CODEVASF tem iniciativas em todos os 217 municípios do Estado, onde realizou investimento em 2019, em Sistemas de Esgotamento Sanitário nos municípios de Brejo, Santa Quitéria, Magalhães de Almeida e Nova Iorque (CODEVASF, 2020). Contudo, a CODEVASF não é uma empresa de saneamento, portanto não possui concessões em nenhum sistema no Estado.

As Figura 6 e Figura 7, a seguir, apresentam a distribuição das instituições que operam os sistemas dos 217 municípios. Como é possível observar, a CAEMA predomina com a maior fatia de operação dos sistemas de abastecimento de água (61\%), e em segundo lugar ficam as Prefeituras (23\%). Contudo, com relação ao esgotamento sanitário, o cenário predomina com a atuação das Prefeituras (84\%) e SAAEs (9\%). Importante destacar que em parte significativa dos municípios não existe sistema coletivo, e por esta razão, as casas possuem fossas sépticas, ou solução equivaente. 
Figura 6 - Distribuição da operação de sistemas de abastecimento de água no Estado do Maranhão pelo número de municípios.

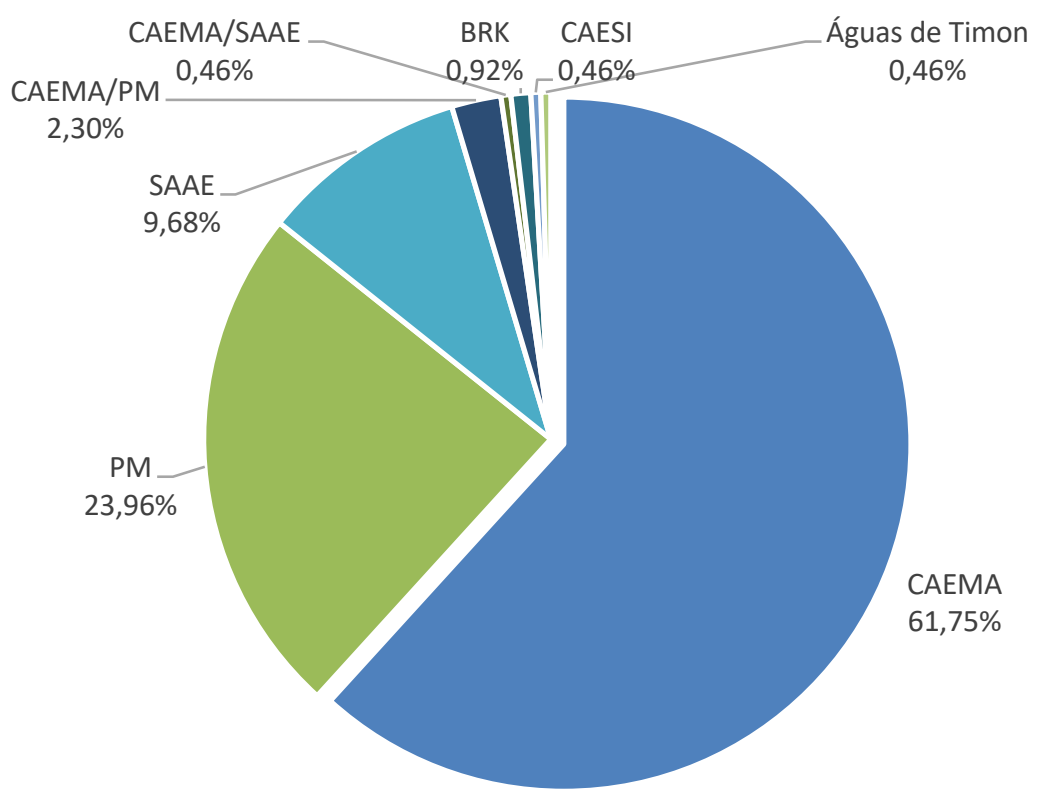

Fonte: Elaborado pela própria autora.

Figura 7 - Distribuição da operação de sistemas de esgotamento no Estado do Maranhão pelo número de municípios.

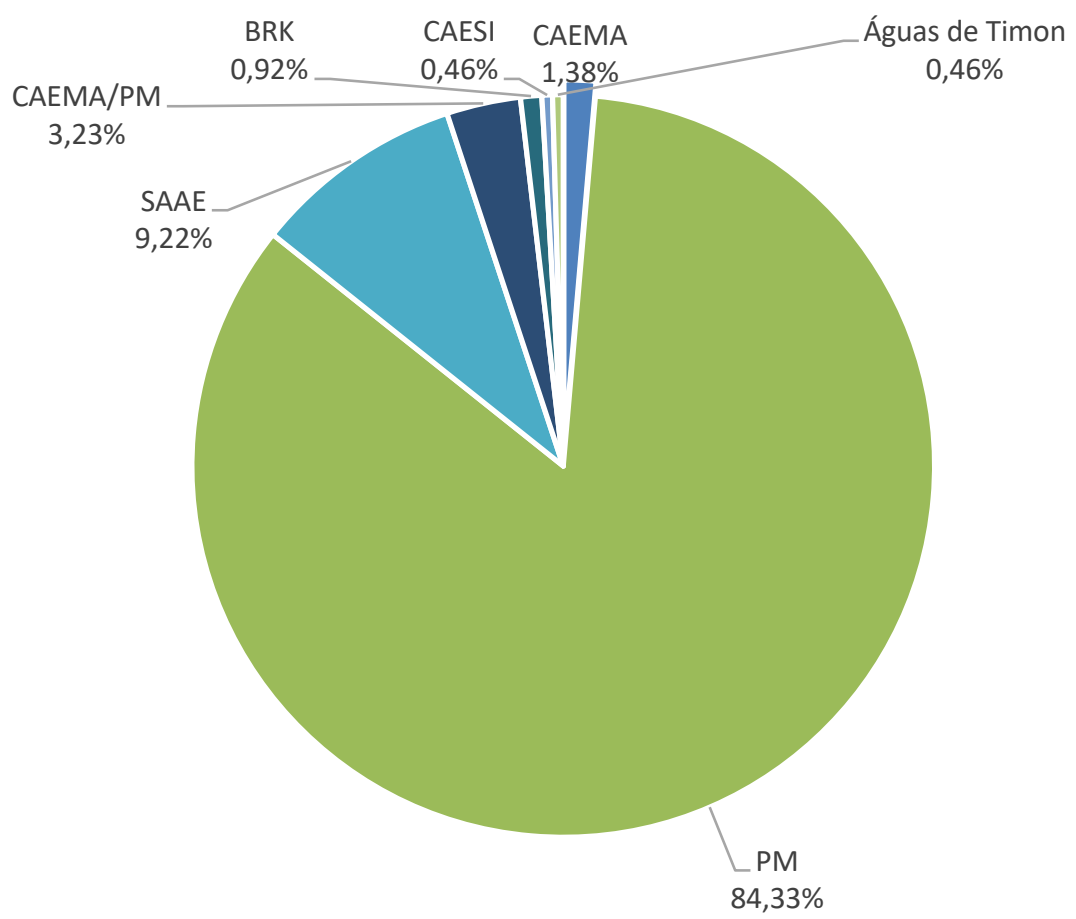

Fonte: Elaborado pela própria autora. 
Observa-se que no caso do Maranhão, o esgotamento sanitário não está previsto em grande parte dos contratos de concessão com a CAEMA e Prefeitura, logo estas atribuições estão separadas. Desta forma, a maioria dos municípios tem seus Sistemas de Abastecimento de Água operados pela CAEMA, enquanto que a responsabilidade pelo esgotamento sanitário é da Prefeitura.

Dentre as entidades responsáveis pela fiscalização e regulação do abastecimento de água e esgotamento sanitário no Estado do Maranhão estão as seguintes Agências Reguladoras de Saneamento Básico:

- Agência Estadual de Transporte e Mobilidade Urbana e Serviços Públicos - MOB

Os serviços de saneamento básico no Estado do Maranhão eram regulados até 2017 pela Agência Reguladora de Serviços Públicos do Maranhão (ARSEMA). A partir da Medida Provisória N N $^{\circ} 29 / 2017$ de 02 de fevereiro de 2017, a ARSEMA foi extinta e suas competências e recursos transferidos à Agência Estadual de Transporte e Mobilidade Urbana e Serviços Públicos (MOB). Desta forma, atualmente a MOB também exerce as funções de regulação, controle e fiscalização dos serviços públicos de saneamento do Estado, como por exemplo, com a regulação da estrutura tarifária referente à prestação dos serviços de saneamento.

A MOB atua como agência reguladora e exerce funções de competência inclusive de Municípios quando the são delegados. Segundo a Lei № 9.861/13 “nos Municípios que não dispuserem de órgão regulador de serviços públicos, no que se refere ao art. $3^{\circ}$, inciso I, alíneas a, b, c e d da Lei Federal $N^{\circ} 11.445$, de 11 de Janeiro de 2007, o poder de controle, regulação e fiscalização será exercido pela ARSEMA”, substituída hoje pela MOB (CAEMA, 2018).

- Agência Reguladora de Serviços Públicos Delegados do Município de Timon - AGERT A Agência Reguladora de Serviços Públicos Delegados do Município de Timon AGERT exerce a regulação e físcalização de serviços públicos de abastecimento de água e esgotamento sanitário delegados pelo Município de Timon, conforme Lei Municipal № 1926, de 11 de setembro de 2014. Suas atribuições envolvem planejamento, acompanhamento e controle dos serviços públicos (AGERT, 2020).

- Consórcio Intermunicipal de Saneamento Básico - CISAB

O Consórcio tem a finalidade de promover a gestão associada da prestação de serviços de saneamento básico nos aspectos relativos a seu planejamento, regulação, fiscalização, e 
contratação da sua prestação, bem como exercer as competências de vigilância sanitária sobre a água de consumo humano (CISAB, 2014). O Consórcio regula e fiscaliza o serviço de saneamento básico nos municípios de São José de Ribamar e Paço Lumiar desde 2014.

Além dos atores do setor de saneamento, é importante destacar a situação dos Planos Municipais de Saneamento Básico (PMSB) do Estado do Maranhão. Para a elaboração destes Planos foi firmada uma parceria entre a Fundação Nacional da Saúde (FUNASA) e a Universidade Federal Fluminense (UFF) para atender os 113 municípios com até 50 mil habitantes do Estado. Além desta iniciativa, a Federação Maranhense dos Consórcios Intermunicipais (FEMACI) tem auxiliado na elaboração de mais 14 PMSBs.

Dentre os municípios que a CAEMA opera, apenas 10 deles estão com o Plano de Saneamento concluído, são eles: Barão do Grajaú, Buriti Bravo, Chapadinha, Colinas, Nova Iorque, Paraibano, São Francisco do Maranhão, São João do Patos, São Luís e Sucupira do Riachão. Outros municípios operados pela Companhia estão com o Plano em elaboração pela própria Prefeitura ou pelas organizações acima citadas. Desta forma, considerando os Planos aprovados, aqueles que passaram em audiência pública e aprovados, oficialmente concluídos, atualmente são 18 PMSBs concluídos, 101 em andamento, e 98 a iniciar.

\section{Novo Marco Regulatório do Saneamento}

Com o advento do Novo Marco Regulatório do Saneamento, o qual foi aprovado no Congresso e sancionado pela Presidência da República, em junho de 2020, o setor está sujeito a diversas modificações. Dentre elas está a nova atribuição da Agência Nacional de Águas e Saneamento Básico (ANA) como agência nacional do setor, que terá como funções estabelecer normas de referência e regulação do saneamento básico no país. Desta forma, as agências existentes ficam sujeitas às orientações da ANA, conforme disposto no Lei No 14.026/2020.

Outra modificação importante se refere à obrigatoriedade dos titulares do serviço a realizarem licitações para a concessão do serviço, de forma a aumentar a concorrência no setor, onde antes o titular possuía a discricionariedade para escolher o órgão que teria a concessão. $\mathrm{O}$ novo Marco define ainda a necessidade de criação da prestação regionalizada que exige a formação de unidade regional de saneamento básico ou blocos de referência de municípios, agrupando municípios com diferentes características, com o intuito de obter ganhos de escala e a viabilidade técnica, econômico e financeira. Com relação aos PMSBs, a partir da necessidade da regionalização, será preciso que estes Planos sejam revistos para se tornarem regionais, logo 
aqueles 101 que estão em andamento devem ser aprovados apenas se o conteúdo estiver contido em um plano regional, conforme a nova Lei.

A nova legislação impõe ainda que sejam cumpridas metas de universalização dos serviços, com $99 \%$ para abastecimento de água e 90\% para esgotamento sanitário, englobando os princípios de redução e controle de perdas, fomento à eficiência energética, reúso de efluentes sanitários e ao aproveitamento de águas de chuva, entre outros.

A discussão para a aprovação do Marco aponta para a ineficiência das companhias estatais que predominam no setor atualmente, tendo em vista que os sistemas estão longe de atingir a universalização do serviço, sendo pouco eficientes e deficitárias. Afirma-se que, com maior segurança jurídica previsto no Novo Marco, este novo cenário favorecerá a entrada do setor privado no mercado de saneamento, e este irá realizar os investimentos necessários para ampliação e melhoria dos sistemas existentes e criação de sistemas de abastecimento e esgotamento sanitário onde inexiste. Por outro lado, alega-se que as empresas privadas irão focar apenas nos sistemas rentáveis, deixando de lado os municípios que não possuem sustentabilidade econômica financeira. E que a entrada do setor privado não é garantia na melhoria do serviço. Além disto, assim como ocorreu com o setor elétrico, a nova Lei não garante a universalização, pelo contrário, poderá tornar o setor mais precário para a população em situação de vulnerabilidade social (MERCEDES, 2002). Desta forma, a nova lei aborda aspectos importantes na mudança da modelagem, que ainda despertam diversas discussões e geram expectativas e necessitam de definição e regulamentação de todos os seus pontos.

\subsection{Caracterização demográfica e sanitária}

Para análise mais apurada do cenário de esgotamento sanitário do Estado, resolveu-se avaliar a situação dos municípios por grupos. Logo, no iníco da pesquisa foi realizada a definição de características norteadoras que influenciam o tratamento de efluentes e a geração de biogás em plantas de tratamento de esgoto, de forma a agrupar os municípios de acordo com sua similaridade demográfica e sanitária. Os aspectos definidos para o agrupamento envolvem características sociais, econômicas, ambientais, técnicas e territoriais dos municípios e são apresentadas a seguir.

- Características sociais e territoriais: estão representadas pelo tamanho da população total e densidade demográfica; 
- Características sociais e técnicas: estão representadas pelo Índice de Desenvolvimento Humano Municipal (IDHM) e Índice de Coleta e Tratamento de Esgoto - solução individual e coletiva;

- Características sociais e econômicas: estão representadas pelo PIB per capita;

Neste caso, considerou-se Índice de Coleta e Tratamento de Esgoto por Solução Individual, aquelas soluções que são utilizadas a nível doméstico, como valas de infiltração, fossa negra e fossa séptica, por exemplo. E para Índice de Coleta e Tratamento de Esgoto por Solução Coletiva, considerou-se soluções a nível municipal ou em condomínios, onde a rede de coleta e o sistema de tratamento recebe a contribuição de esgoto doméstico de diversas residências.

Conforme estabelece a Norma de Projeto da Associação Brasileira de Normas Técnicas $(\mathrm{ABNT})$, para a construção e operação de sistemas de tanques sépticos (ASSOCIAÇÃO BRASILEIRA NORMAS TÉCNICAS - ABNT, 1993), a vazão de produção de esgoto por pessoa em sua residência pode variar entre 100 a 160L/d. Sendo assim, no Apêndice C é apresentado o valor estimado de esgoto produzido por município, como todos os valores das características mecionadas acima.

Após a coleta destas informações para cada município, estes foram divididos em quatro grupos de acordo com sua similariedade demográfica e sanitária, utilizando o software STATA. Para o agrupamento dos municípios foram utilizadas ferramentas estatísticas como a análise de cluster pela metodologia de K-means, o que resultou nos grupos a seguir. Importante lembrar que a primeira separação dos grupos foi realizada antes da finalização do levantamento com os questionários. Desta forma, os dados considerados no primeiro agrupamento para cobertura de esgotamento sanitário são da ANA e do SNIS. Utilizou-se a mediana dos valores dos municípios de cada grupo, com intuito de indicar a tendência central do grupo de informações.

Caracterização dos grupos:

Grupo 01 - Composto por quatro municípios - Este grupo tem como características principais: os maiores números de população, densidade demográfica e de IDHM no Estado, conforme apresentado na Tabela 9; 
Tabela 9 - Caracterísiticas demográficas e sanitárias do Grupo 01.

\begin{tabular}{|c|c|c|}
\hline & Grupo 1 & $\begin{array}{l}\text { Grupo } 1 \\
\text { Mediana }\end{array}$ \\
\hline Número de habitantes (hab) & 1,09 milhão - 120mil & $217.168,50$ \\
\hline $\begin{array}{l}\text { Densidade demográfica } \\
\left(\mathbf{h a b} / \mathbf{k m}^{2}\right)\end{array}$ & $\begin{array}{c}1310 \mathrm{hab} / \mathrm{km}^{2} \text { a } 188 \\
\mathrm{hab} / \mathrm{km}^{2}\end{array}$ & 717,55 \\
\hline PIB per capita (R\$/hab) & $\mathrm{R} \$ 26 \mathrm{mil}$ a $\mathrm{R} \$ 6 \mathrm{mil}$ & $\mathrm{R} \$ 18.481,00$ \\
\hline IDHM & 0,768 a 0,708 & 0,7275 \\
\hline Solução individual (\%) & $26 \%-14 \%$ & $19,20 \%$ \\
\hline Solução coletiva $(\%)$ & $36 \%-0 \%$ & $7,90 \%$ \\
\hline Vazão estimada de esgoto $(\mathrm{L} / \mathrm{s})$ & $1.647-181$ & 327 \\
\hline
\end{tabular}

Grupo 02 - Composto por 58 municípios - Este grupo tem como caraterísticas possuir parâmetros inferiores ao Grupo 01, com exceção da cobertura por solução individual que varia de aproximadamente $37 \%$ a $7 \%$, conforme Tabela 10 . Observa-se que os valores demográficos reduzem significativamente.

Tabela 10 - Caracterísiticas demográficas e sanitárias do Grupo 02.

\begin{tabular}{|c|c|c|}
\hline & \multirow{2}{*}{ Grupo 2} & Grupo 2 \\
\hline & & Mediana \\
\hline Número de habitantes (hab) & 167 mil - 4,6mil & $23.493,00$ \\
\hline $\begin{array}{l}\text { Densidade demográfica } \\
\left(\mathbf{h a b} / \mathbf{k m}^{2}\right)\end{array}$ & $\begin{array}{c}459 \mathrm{hab} / \mathrm{km}^{2} \text { a } 2,3 \\
\text { hab } / \mathrm{km}^{2}\end{array}$ & 27,13 \\
\hline PIB per capita (R\$/hab) & $\mathrm{R} \$ 56 \mathrm{mil}$ a $\mathrm{R} \$ 4,8 \mathrm{mil}$ & $\mathrm{R} \$ 7.407,00$ \\
\hline IDHM & 0,687 a 0,516 & 0,5905 \\
\hline Solução individual (\%) & $37 \%-7 \%$ & $22,40 \%$ \\
\hline Solução coletiva $(\%)$ & $26 \%-0 \%$ & $0,00 \%$ \\
\hline Vazão estimada de esgoto (L/s) & $252-7$ & 35 \\
\hline
\end{tabular}

Fonte: Adaptado de ANA, 2017; IBGE, 2010, 2019; PNUD; MMA, 2010.

Grupo 03 - Composto por 25 municípios - Este grupo tem como caraterísticas possuir parâmetros inferiores ao Grupo 02, com exceção do PIB per capita e da cobertura por solução individual que varia de aproximadamente $95 \%$ a $35 \%$, de solução coletiva de $40 \%$ a $0 \%$, e possui também valor similar de densidade demográfica, conforme Tabela 11. 
Tabela 11 - Caracterísiticas demográficas e sanitárias do Grupo 03.

\begin{tabular}{|c|c|c|}
\hline & Grupo 3 & $\begin{array}{l}\text { Grupo } 3 \\
\text { Mediana }\end{array}$ \\
\hline Número de habitantes (hab) & 164 mil - 3,5mil & $16.013,00$ \\
\hline $\begin{array}{l}\text { Densidade demográfica } \\
\left(\mathrm{hab} / \mathbf{k m}^{2}\right)\end{array}$ & $\begin{array}{c}62 \mathrm{hab} / \mathrm{km}^{2} \text { a } 3,2 \\
\mathrm{hab} / \mathrm{km}^{2}\end{array}$ & 27,06 \\
\hline PIB per capita (R\$/hab) & $\mathrm{R} \$ 20 \mathrm{mil}$ a $\mathrm{R} \$ 4,6 \mathrm{mil}$ & $\mathrm{R} \$ 6.863,00$ \\
\hline IDHM & 0,651 a 0,452 & 0,569 \\
\hline Solução individual (\%) & $95 \%-35 \%$ & $49,60 \%$ \\
\hline Solução coletiva (\%) & $40 \%-0 \%$ & $0,00 \%$ \\
\hline Vazão estimada de esgoto $(\mathrm{L} / \mathrm{s})$ & $247-5$ & 24 \\
\hline
\end{tabular}

Grupo 04 - Composto por 130 municípios - Este grupo corresponde 60\% dos municípios maranhenses, e tem como caraterísticas apresentar valores demográficos e sanitáris reduzidos em relação aos outros grupos, com exceção do número de habitantes que apresenta um valor de mediana similar ao Grupo 03, e do valor igual para estimativa de vazão de esgoto, conforme Tabela 12.

Tabela 12 - Caracterísiticas demográficas e sanitárias do Grupo 04.

\begin{tabular}{|c|c|c|}
\hline & \multirow{2}{*}{ Grupo 4} & Grupo 4 \\
\hline & & Mediana \\
\hline Número de habitantes (hab) & 72 mil - 4,6mil & $16.173,50$ \\
\hline $\begin{array}{l}\text { Densidade demográfica } \\
\left(\mathbf{h a b} / \mathbf{k m}^{2}\right)\end{array}$ & $\begin{array}{c}119 \mathrm{hab} / \mathrm{km}^{2} \text { a } 1 \\
\mathrm{hab} / \mathrm{km}^{2}\end{array}$ & 17,5 \\
\hline PIB per capita (R\$/hab) & $\mathrm{R} \$ 89 \mathrm{mil}$ a $\mathrm{R} \$ 4,2 \mathrm{mil}$ & $\mathrm{R} \$ 6.484,00$ \\
\hline IDHM & 0,684 a 0,443 & 0,561 \\
\hline Solução individual (\%) & $18 \%-0 \%$ & $3,20 \%$ \\
\hline Solução coletiva $(\%)$ & $42 \%-0 \%$ & $0,00 \%$ \\
\hline Vazão estimada de esgoto $(\mathrm{L} / \mathrm{s})$ & $109-7$ & 24 \\
\hline
\end{tabular}

Fonte: Adaptado de ANA, 2017; IBGE, 2010, 2019; PNUD; MMA, 2010.

Comparando-se os quatro grupos pelos valores da mediana das características dos municípios, observa-se as principais diferenças entre cada um, conforme Tabela 13. 
Tabela 13 - Características dos Grupos com base no valor da mediana.

\begin{tabular}{lcccc}
\hline & Grupo 01 & Grupo 02 & Grupo 03 & Grupo 04 \\
\cline { 2 - 5 } & Mediana & Mediana & Mediana & Mediana \\
\hline Número de habitantes (hab) & $217.168,50$ & $23.493,00$ & $16.013,00$ & $16.173,50$ \\
\hline $\begin{array}{l}\text { Densidade demográfica } \\
\text { (hab/km }\end{array}$ & 717,55 & 27,13 & 27,06 & 17,5 \\
\hline PIB per capita (R\$/hab) & $\mathrm{R} \$ 18.481,00$ & $\mathrm{R} \$ 7.407,00$ & $\mathrm{R} \$ 6.863,00$ & $\mathrm{R} \$ 6.484,00$ \\
\hline IDHM & 0,7275 & 0,5905 & 0,569 & 0,561 \\
\hline Solução individual (\%) & $19,20 \%$ & $22,40 \%$ & $49,60 \%$ & $3,20 \%$ \\
\hline Solução coletiva (\%) & $7,90 \%$ & $0,00 \%$ & $0,00 \%$ & $0,00 \%$ \\
\hline Vazão estimada de esgoto $\mathbf{( L / s )}$ & 327 & 35 & 24 & 24 \\
\hline
\end{tabular}

Fonte: Adaptado de ANA, 2017; IBGE, 2010, 2019; PNUD; MMA, 2010.

A separação dos grupos foi utilizada também para realizar a coleta de amostras, onde foi selecionado um município em cada grupo. O levantamento de informações, o qual utilizou o método Snowball sampling e o questionário semi-estruturado do Apêndice B, permitiu identificar as diferenças significativas nos valores de cobertura por solução individual e coletiva. O compilado dos dados no Apêndice $\mathrm{C}$ apresenta as diferenças entre os valores do levantamento com o questionário e da base de dados do SNIS e Atlas. Desta forma, apesar da existência do SNIS e o Atlas do Esgoto, que facilita significativamente a compilação das diversas informações e indicadores por município no Brasil, observa-se que existem problemas de confiabilidade e atualização dos dados, bem como, da falta de informações.

Tendo em vista, que as diferenças influenciam a distribuição dos municípios nos grupos, realizou-se a mesma análise com os dados atualizados, a partir do levantamento. O resultado do novo reagrupamento é apresentado na Tabela 14, a seguir. Importante destacar que pelo levantamento, muitos entrevistados apontaram que os municípios apresentavam solução individual em todo o município, por esta razão, optou-se por apontar que $100 \%$ do município teria cobertura de solução individual, como por fossa séptica, sumidouro, entre outros. Contudo, considera-se não ser um dado preciso, e existe a possibilidade de que parte da população possa não ter acesso a estas soluções.

Tabela 14 - Reagrupamento de municípios após levantamento.

\begin{tabular}{cc}
\hline $\mathbf{N}^{\mathbf{0}}$ do grupo & $\begin{array}{c}\text { Quantidade de } \\
\text { municípios }\end{array}$ \\
\hline $\mathbf{1}$ & 6 \\
\hline $\mathbf{2}$ & 65 \\
\hline $\mathbf{3}$ & 146 \\
\hline Total Geral & $\mathbf{2 1 7}$ \\
\hline
\end{tabular}

Fonte: Elaborado pela própria autora. 
Na nova distribuição, observou-se que havia um grupo com apenas três municípios, com características similares a municípios de outros grupos, não sendo necessária sua diferenciação. Desta maneira, reduziu-se a divisão dos grupos, de quatro para três. A comparação dos valores das medianas dos grupos é apresentado na Tabela 15, abaixo, onde observa-se que as diferenças entre os grupos são melhor definidas.

Tabela 15 - Características dos Grupos redistribuídos com base no valor da mediana.

\begin{tabular}{lccc}
\hline & Grupo 01 & Grupo 02 & Grupo 03 \\
\cline { 2 - 4 } & Mediana & Mediana & Mediana \\
\hline Número de habitantes $(\mathbf{h a b})$ & 149.459 & 23.696 & 16.442 \\
\hline Densidade demográfica $\left(\mathbf{h a b} / \mathbf{k m}^{\mathbf{2}}\right)$ & 300,305 & 24,25 & 17,61 \\
\hline PIB per capita $(\mathbf{R} \mathbf{\text { hab}})$ & $\mathrm{R} \$ 13.822,50$ & $\mathrm{R} \$ 9.350,00$ & $\mathrm{R} \$ 6.290,00$ \\
\hline IDHM & 0,715 & 0,610 & 0,560 \\
\hline Solução individual (\%) & $57,50 \%$ & $100,00 \%$ & $100,00 \%$ \\
\hline Solução coletiva (\%) & $42,50 \%$ & $0,00 \%$ & $0,00 \%$ \\
\hline
\end{tabular}

Fonte: Adaptado de ANA, 2017; IBGE, 2010, 2019; PNUD; MMA, 2010.

\subsection{Caracterização da infraestrutura}

A partir do levantamento de informações com os dados referentes à situação atual da coleta e tratamento de esgoto foi possível analisar a infraestrura de esgotamento sanitário no Estado. Observa-se que o percentual de municípios que apresentam cobertura de coleta e tratamento por solução coletiva no Estado é de aproximadamente, 9,21\%, ou seja, apenas 20 municípios apresentam alguma infraestrutura de esgotamento sanitário por solução coletiva, seja municipal ou em loteamento. Desta forma, a maioria dos municípios, 197 (90,79\%) possuem apenas soluções individuais, como fossas sépticas, valas, entre outros, nas casas. Em geral, baseado nos dados levantados, o Estado possui uma cobertura de coleta e tratamento do esgoto de aproximadamente, $2,25 \%$, em contraposição à $4 \%$ apresentado pela ANA. Segundo o SNIS (2018), os sistemas operados pela CAEMA com esgotamento sanitário, possuem cobertura para coleta e tratamento de esgoto urbana média de 43,96\% nos municípios que opera a nível municipal, contudo, baseado no levantamento, este valor reduz para 28,3\%. Ainda com base no levantamento, os sistemas operados pelo SAAE tem cobertura média de $10 \%$, e as Prefeituras, o percentual é de $0,2 \%$, para sistemas coletivos de esgotamento sanitário. Os três sistemas operados por empresas privadas possuem cobertura de coleta e tratamento de aproximadamente 44,2\%, com base no levantamento, em relação à 55,34\% indicado pelo (SNIS, 2018). Importante destacar que estes percentuais envolvem tanto a coleta como o 
tratamento de esgoto. Em São Luís, na capital do Estado por exemplo, a coleta do esgoto abrange aproximadamente $73,14 \%$ do total gerado no município, enquanto o tratamento corresponde a aproximadamente $24,63 \%$ do total gerado, (SNIS, 2018), logo o valor de coleta e tratamento do esgoto gerado por solução coletiva passa a ser $18,01 \%$.

No que tange a discussão sobre o desempenho das empresas privadas em detrimento das empresas públicas, observa-se que nos municípios onde opera a BRK, a quantidade de ETEs é maior em relação a outros municípios operados pela CAEMA, demonstrando a necessidade de maior investimento por parte da estatal no esgotamento sanitário do Estado. Estas ETEs operadas pela BRK estão localizadas principalmente em loteamentos residenciais. Observa-se também, a baixa capacidade dos SAAEs, e principalemente, Prefeituras, em investir em infraestrutura para esgoto nas cidades. Segundo o Atlas do Esgoto, o Maranhão está classificado entre os Estados do Grupo C - Situação Institucional Básica, onde a maior parte dos municípios contém fragilidades institucionais, ou seja, não possuem prestador de serviço ou o prestador é pouco estruturado e com baixa capacidade de realizar investimentos, bem como baixa capacidade operacional, dificultando ainda mais a melhoria do déficit do esgotamento sanitário nestes municípios (ANA, 2017).

Com relação à localização das ETEs, não foi possível obter a coordenada exata em todos os municípios e, no que se refere às redes de coleta, apenas poucos municípios com coleta de esgoto souberam informar sobre a disponibilidade desta informação. Referente ao tratamento, foram encontradas 68 ETEs em todo o Estado, e estas foram detalhadas com o porte, tipo de tecnologia de tratamento, órgão responsável e a vazão afluente média, no Apêndice D. A maioria das plantas são de pequeno porte (59) e estão localizadas em Residenciais (50).

Importante ressaltar que existem ETEs em construção, como em Itapecuru Mirim, que não foram contabilizados no levantamento, pois ainda não estão em funcionamento. Na Figura 8, estão representadas as ETEs do Apêndice D espacializadas no Estado. Observa-se uma concentração no município de São Luís, São José de Ribamar, Paço Lumiar e Imperatriz. 
Figura 8. Distribuição das ETEs no Maranhão.

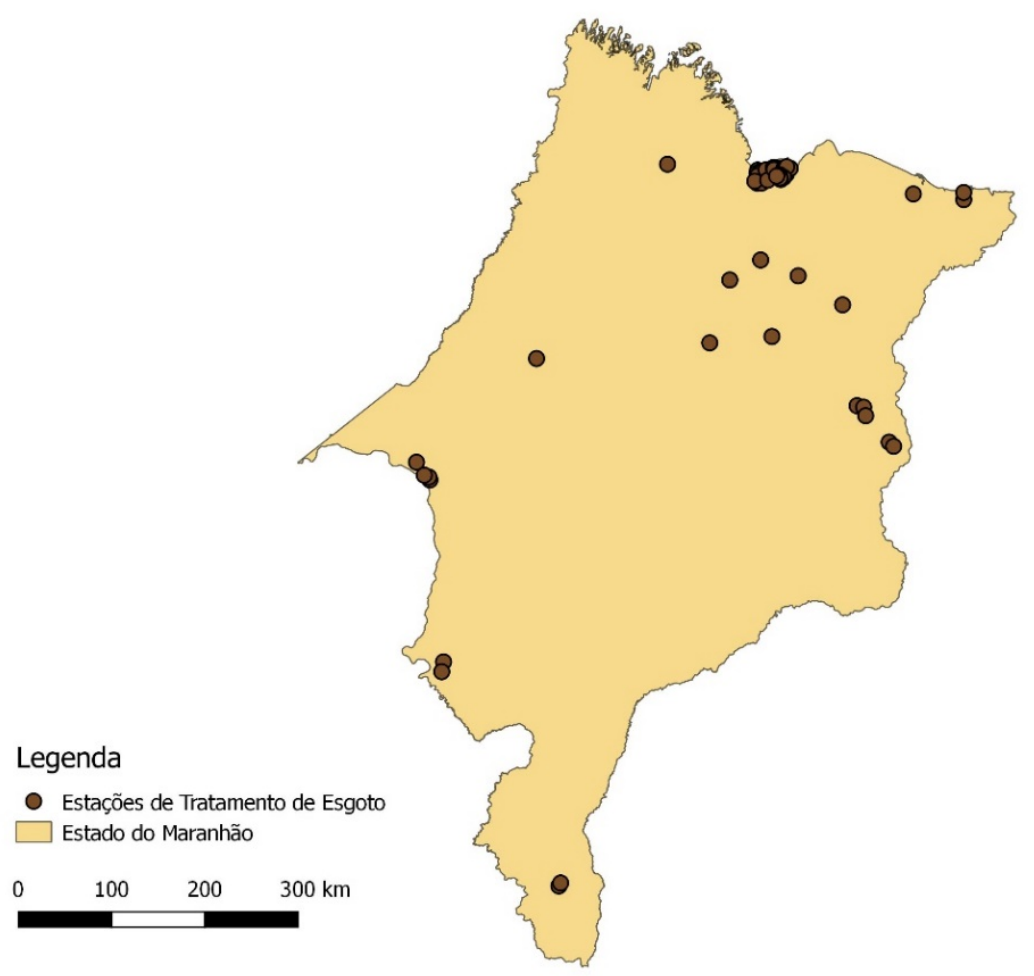

Fonte: Elaborado pela própria autora.

Observa-se também a predominância da solução de ETEs em Residenciais (54) em detrimento de soluções municipais (14), no Estado. Os reatores estão presentes em 49 plantas, as lagoas de estabilização em 10, lodos ativados em seis, e tanques sépticos em três plantas. $\mathrm{Na}$ Figura 9, observa-se a predominância do reator como solução no Estato dentre as plantas existentes, indicando o potencial para aproveitamento do biogás.

Figura 9 - Quantidade de soluções de tratamento de esgoto por tipo de tecnologia.

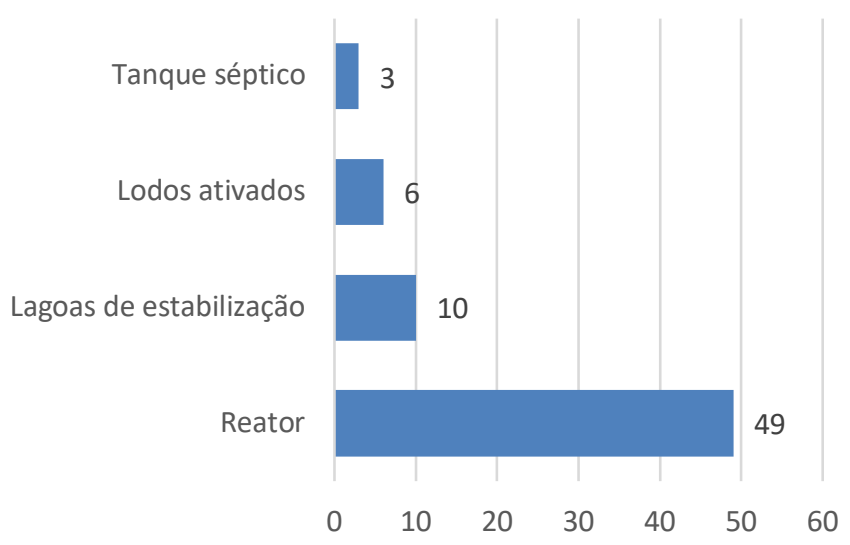

Fonte: Elaborado pela própria autora. 


\section{Tecnologias de tratamento}

No Estado existe apenas uma planta de grande porte, no município de Imperatriz, que utiliza a tecnologia de Lagoa de Estabilização, com uma lagoa anaeróbia, seguida de lagoa facultativa, com uma vazão afluente de, aproximadamente, $208 \mathrm{~L} / \mathrm{s}$. Em conjunto com mais 3 ETEs em residenciais, com reatores anaeróbios, Imperatriz apresenta uma cobertura aproximada de 36,21\% de coleta e tratamento do esgoto no município (SNIS, 2018).

Considerando as plantas de tratamento de esgoto médio porte no Estado, são elas: ETE Jaracaty e ETE Vinhais, e estão localizadas na capital. Em São Luís existem ainda duas ETEs de pequeno porte com a mesma tecnologia, são elas: ETE Bacanga e ETE Anil (em construção). Estas ETEs utilizam reatores de manta de lodo e fluxo ascendente (UASB) em conjunto com a oxidação avançada por ozônio para desinfecção do efluente. As plantas da capital apresentam os seguintes componentes principais:

Pré tratamento: Gradeamento mecanizado e desarenador;

Tratamento secundário: Reator UASB (anaeróbio);

Tratamento terciário: Ozonização;

Tratamento do lodo: Centrífuga ou Leito de Secagem;

Tratamento do gás: Queimador de biogás.

Em São Luís, nas ETEs, o tratamento atinge eficiência de remoção de matéria orgânica superiores a 70\% com estes componentes. Contudo, os reatores projetados nestas unidades são semelhantes e já apresentam problemas operacionais. A ETE Vinhais está ativa desde 2016, enquanto que a ETE Jaracaty e ETE Bacanga estão ativas a mais de 20 anos, e a ETE Anil está em construção.

Dentre os principais problemas técnicos detectados nas ETEs estão: a quantidade de areia presente no efluente e sua granulometria fina; elevado volume de água da chuva que é coletado junto do efluente em certos períodos do ano; elevado consumo de energia principalmente com a ozonização; e a qualidade do biogás que pode gerar elevadas quantidades de ácido sulfídrico e tem ocasionado o desgaste do revestimento interno das paredes do reator (NBS ENGENHARIA, 2018b). Atualmente nestas ETEs, o biogás é queimado em queimadores para converter o metano em gás carbônico e reduzir a emissão de GEEs (NBS ENGENHARIA, 2018a).

Além das ETEs em Imperatriz e São Luís, existem ETEs em outros municípios como São José de Ribamar, Barreirinhas, Carolina, Bacabal, Codó, dentre outros, com plantas municipais 
majoritariamento de pequeno porte. Nestes sistemas estão presentes ETEs municipais e em Residenciais. Estas plantas empregam processos aeróbios e anaeróbios combinados, principalmente para condomínios entre 1 mil a 4 mil habitantes. O Apêndice D elenca as ETEs existentes no Estado e o tipo de tratamento utilizado em cada uma e no Apêndice C estão as quantidades de ETEs por município.

Existem ainda soluções individuais, como kit sanitário, o qual é construído para famílias em situação de vulnerabilidade social e que não possuem banheiro em sua residência. Nos últimos anos, a CAEMA e a FUNASA construíram kits em alguns municípios do Estado, os quais são compostos de uma construção de alvenaria, fossa séptica e sumidouro. A CAEMA construiu 934 kits, de 2017 a 2019. Dentre as soluções individuais existem também as fossas rudimentares, fossas negras, valas, entre outras.

\subsection{Discussão do estudo de caso}

Com o panorama geral da situação do esgotamento sanitário no Estado, é possível ter uma visão mais atualizada, que servirá para pensar estratégias de impulsionar o cenário do esgotamento sanitário no Maranhão, onde o uso da recuperação energética pode auxiliar, não só para melhoria das condições sanitárias, mas também na geração de energia. Importante destacar que, assim como prevê o Novo Marco Regulatório do setor, as soluções podem ser pensadas de forma consorciada, principalmente no caso dos médios e pequenos municípios, com o uso do lodo de esgoto, por exemplo, para seu tratamento e descarte de forma ambientalmente adequada.

Observa-se ainda, que nos municípios onde atua a empresa privada BRK, desde de 2014, apresentam índices de cobertura de esgotamento sanitário elevados, acima de 35\%, em relação aos municípios do restante do Estado. Este aspecto levanta o questionamento sobre a capacidade de investimento no setor por parte dos outros atores e também sobre a importância da capilaridade que as companhias de saneamento possuem. Destaca-se então, a importância das Parcerias Público Privadas (PPP), bem estruturadas, de forma a acelerar os investimentos no setor, principalmente nos municípios em maior situação de vulnerabilidade, unindo assim a capacidade da Companhia Estadual de abrangência de operação, com a capacidade de investimento externo. Além disto, com o levantamento da infraestrutura existente é possível aprofundar as análises, com o intuito de ampliar e melhorar as instalações, ao mesmo tempo que é possível entender as adequaçõs que devem ser feitas para a construção de infraestrutura em municípios onde ainda não existe Sistema de Esgotamento Sanitário. 


\section{Análise do potencial de biogás}

Neste capítulo são apresentados os detalhes para estimativa de geração de biogás a partir de efluentes no Estado do Maranhão, através da análise do potencial teórico e empirico.

\subsection{Metodologia de análise das amostras e cálculo do potencial de biogás}

Visando alcançar o objetivo de avaliar o potencial de geração de biogás no Estado, foram realizadas análises de potencial teórico, com uso de fórmulas e empírico, por meio de ensaios laboratoriais e coleta de dados nos aferidores de pressão em campo. Para o potencial teórico e o empírico laboratorial, foi realizada a coleta e análise de amostras de efluentes domésticos em alguns municípios. A escolha dos municípios envolveu a seleção de características consideradas relevantes para a produção de biogás a partir de efluentes domésticos, definidos com base na literatura e na distribuição das tecnologias atualmente no país, como explicado no item 4.3. A partir do levantamento destes dados, os municípios foram agrupados em quatro divisões. $\mathrm{O}$ resultado do agrupamento está apresentado na Tabela 16, a seguir.

Tabela 16 - Resultado do agrupamento dos municípios pela análise de cluster.

\begin{tabular}{cc}
\hline $\mathbf{N}^{\mathbf{0}}$ do grupo & Quantidade de municípios \\
\hline $\mathbf{1}$ & 4 \\
\hline $\mathbf{2}$ & 58 \\
\hline $\mathbf{3}$ & 25 \\
\hline $\mathbf{4}$ & 130 \\
\hline Total Geral & $\mathbf{2 1 7}$ \\
\hline
\end{tabular}

Fonte: Elaborado pela própria autora.

A partir deste agrupamento foram realizadas duas coletas. A primeira ocorreu em Maio de 2019 e a segunda em Outubro de 2019. Os municípios escolhidos para a Coleta 01 foram os seguintes: Grupo 1 - São Luís, Grupo 2 - Itapecuru Mirim, Grupo 3 - Bacabal e Codó, Grupo 4 - Lagoa Grande do Maranhão. Para a Coleta 02: Grupo 1 - São Luís, Grupo 2 - Coroatá, Grupo 3 - Codó, Grupo 4 - Miranda do Norte e Afonso Cunha. A seleção foi realizada com base no trajeto a ser percorrido no período de três dias de cada coleta. A Tabela 17 apresenta os detalhes sobre os municípios onde foi realizada a Coleta 01 e a Tabela 18 sobre a Coleta 02 . 
Tabela 17 - Detalhamento de informações sobre as amostras da Coleta 01.

\begin{tabular}{|c|c|c|c|c|c|c|c|}
\hline Coleta & $\begin{array}{c}\text { Data e } \\
\text { Horário }\end{array}$ & Município & $\begin{array}{l}\text { Ponto de } \\
\text { coleta }\end{array}$ & $\begin{array}{c}\text { Tecnologia } \\
\text { de } \\
\text { tratamento }\end{array}$ & $\begin{array}{l}\text { Cobertura } \\
\text { de água }\end{array}$ & $\begin{array}{l}\text { Cobertura de } \\
\text { esgoto Solução } \\
\text { Coletiva }\end{array}$ & $\begin{array}{l}\text { Operação do } \\
\text { Sistema de } \\
\text { Água e Esgoto }\end{array}$ \\
\hline 1 & $\begin{array}{c}11 / 05 / 2019 \\
10: 30 \mathrm{~h}\end{array}$ & $\begin{array}{l}\text { Itapecuru } \\
\text { Mirim }\end{array}$ & $\begin{array}{c}\text { ETE } \\
\text { Residencial } \\
\text { Isabel } \\
\text { Mendes }\end{array}$ & $\begin{array}{c}\text { Reator } \\
\text { Anaeróbico }\end{array}$ & $\begin{array}{c}100 \% \text { da } \\
\text { população } \\
\text { dos } \\
\text { Residenciais }\end{array}$ & $\begin{array}{c}\text { Residencial } \\
\text { Isabel Mendes e } \\
\text { Enezio Filgueira } \\
\quad 800 \text { casas }\end{array}$ & $\begin{array}{c}\text { CAEMA (Água } \\
\text { e Esgoto no } \\
\text { Residencial) } \\
\text { e Prefeitura } \\
\text { (Esgoto) }\end{array}$ \\
\hline 2 & $\begin{array}{c}11 / 05 / 2019 \\
14: 15 \mathrm{~h}\end{array}$ & Codó & $\begin{array}{c}\text { Estação } \\
\text { Elevatória }\end{array}$ & $\begin{array}{c}\text { Lagoa } \\
\text { facultativa }\end{array}$ & $\begin{array}{c}95 \% \text { da } \\
\text { população }\end{array}$ & $\begin{array}{c}30 \text { a } 40 \% \text { da } \\
\text { população }\end{array}$ & $\begin{array}{l}\text { SAAE (Água e } \\
\text { Esgoto) }\end{array}$ \\
\hline 3 & $\begin{array}{c}11 / 05 / 2019 \\
17: 30 \mathrm{~h}\end{array}$ & Bacabal & $\begin{array}{l}\text { Estação } \\
\text { Elevatória }\end{array}$ & $\begin{array}{c}\text { Lagoa } \\
\text { aeróbica } \\
\text { facultativas }\end{array}$ & $\begin{array}{c}95 \% \text { da } \\
\text { população }\end{array}$ & $\begin{array}{c}10 \% \text { da } \\
\text { população }\end{array}$ & $\begin{array}{l}\text { SAAE (Água e } \\
\text { Esgoto) }\end{array}$ \\
\hline 4 & $\begin{array}{c}12 / 05 / 2019 \\
10: 45 \mathrm{~h}\end{array}$ & $\begin{array}{l}\text { Lagoa } \\
\text { Grande do } \\
\text { Maranhão }\end{array}$ & $\begin{array}{l}\text { Ponto de } \\
\text { acúmulo de } \\
\text { esgoto na } \\
\text { rua }\end{array}$ & - & $\begin{array}{c}90 \% \text { da } \\
\text { população }\end{array}$ & - & $\begin{array}{l}\text { Prefeitura (Água } \\
\text { e Esgoto) }\end{array}$ \\
\hline 5 & $\begin{array}{c}13 / 05 / 2019 \\
13: 15 \mathrm{~h}\end{array}$ & São Luís & $\begin{array}{c}\text { ETE } \\
\text { Vinhais }\end{array}$ & $\begin{array}{c}\text { Reator } \\
\text { Anaeróbico }\end{array}$ & $\begin{array}{c}86 \% \text { da } \\
\text { população }\end{array}$ & $\begin{array}{c}20 \% \text { da } \\
\text { população }\end{array}$ & $\begin{array}{c}\text { CAEMA (Água } \\
\text { e Esgoto) }\end{array}$ \\
\hline
\end{tabular}

Fonte: Elaborado pela própria autora.

Tabela 18 - Detalhamento de informações sobre as amostras da Coleta 02.

\begin{tabular}{|c|c|c|c|c|c|c|c|}
\hline Coleta & $\begin{array}{c}\text { Data e } \\
\text { Horário }\end{array}$ & Município & $\begin{array}{l}\text { Ponto de } \\
\text { coleta }\end{array}$ & $\begin{array}{l}\text { Tecnologia } \\
\text { de } \\
\text { tratamento }\end{array}$ & $\begin{array}{l}\text { Cobertura } \\
\text { de água }\end{array}$ & $\begin{array}{c}\text { Cobertura de } \\
\text { esgoto } \\
\text { Solução Coletiva }\end{array}$ & $\begin{array}{l}\text { Operação do } \\
\text { Sistema de } \\
\text { Água e Esgoto }\end{array}$ \\
\hline 1 & $\begin{array}{c}\text { 05/10/2019 } \\
09: 30 \mathrm{~h}\end{array}$ & $\begin{array}{l}\text { Miranda } \\
\text { do Norte }\end{array}$ & $\begin{array}{l}\text { Entrada da } \\
\text { ETE Res. } \\
\text { Santa } \\
\text { Bárbara II }\end{array}$ & $\begin{array}{l}\text { Lagoas } \\
\text { facultativas } \\
\text { (não estava } \\
\text { operação) }\end{array}$ & $\begin{array}{l}100 \% \text { do } \\
\text { Residencial }\end{array}$ & $\begin{array}{c}\text { Residencial Santa } \\
\text { Bárbara II - } 400 \\
\text { res. }\end{array}$ & $\begin{array}{l}\text { CAEMA (Água } \\
\text { e Esgoto no } \\
\text { Residencial) } \\
\text { e Prefeitura } \\
\text { (Esgoto) }\end{array}$ \\
\hline 2 & $\begin{array}{c}\text { 05/10/2019 } \\
13: 00 \mathrm{~h}\end{array}$ & Coroatá & $\begin{array}{c}\text { ETE } \\
\text { Residencial } \\
\text { Ecomarajá }\end{array}$ & $\begin{array}{c}\text { Reator } \\
\text { Anaeróbio }\end{array}$ & $\begin{array}{l}100 \% \text { do } \\
\text { Residencial }\end{array}$ & $\begin{array}{l}\text { Residencial } \\
\text { Ecomarajá - } 700 \\
\text { residências }\end{array}$ & $\begin{array}{c}\text { CAEMA (Água } \\
\text { e Esgoto no } \\
\text { Residencial) } \\
\text { e Prefeitura } \\
\text { (Esgoto) }\end{array}$ \\
\hline 3 & $\begin{array}{c}05 / 10 / 2019 \\
16: 30 \mathrm{~h}\end{array}$ & Codó & Elevatória & $\begin{array}{c}\text { Lagoa } \\
\text { facultativa }\end{array}$ & $\begin{array}{c}95 \% \text { da } \\
\text { população }\end{array}$ & $\begin{array}{c}30 \text { a } 40 \% \text { da } \\
\text { população }\end{array}$ & $\begin{array}{l}\text { SAAE (Água e } \\
\text { Esgoto) }\end{array}$ \\
\hline 4 & $\begin{array}{c}06 / 10 / 2019 \\
11: 30 \mathrm{~h}\end{array}$ & $\begin{array}{l}\text { Afonso } \\
\text { Cunha }\end{array}$ & $\begin{array}{l}\text { Ponto de } \\
\text { acúmulo de } \\
\text { esgoto na } \\
\text { rua }\end{array}$ & - & $\begin{array}{c}95 \% \text { da } \\
\text { população }\end{array}$ & - & $\begin{array}{c}\text { Prefeitura e } \\
\text { CAEMA (Água) } \\
\text { e Prefeitura } \\
\text { (Esgoto) }\end{array}$ \\
\hline 5 & $\begin{array}{c}07 / 10 / 2019 \\
13: 15 \mathrm{~h}\end{array}$ & São Luís & $\begin{array}{c}\text { ETE } \\
\text { Vinhais }\end{array}$ & $\begin{array}{c}\text { Reator } \\
\text { Anaeróbico }\end{array}$ & $\begin{array}{c}86 \% \text { da } \\
\text { população }\end{array}$ & $24 \%$ da população & CAEMA \\
\hline
\end{tabular}

Fonte: Elaborado pela própria autora. 
A distribuição das coletas no Estado se deram conforme os mapas abaixo, Figura 10.

Figura 10 - Distribuição dos municípios de realização da coleta de amostras.

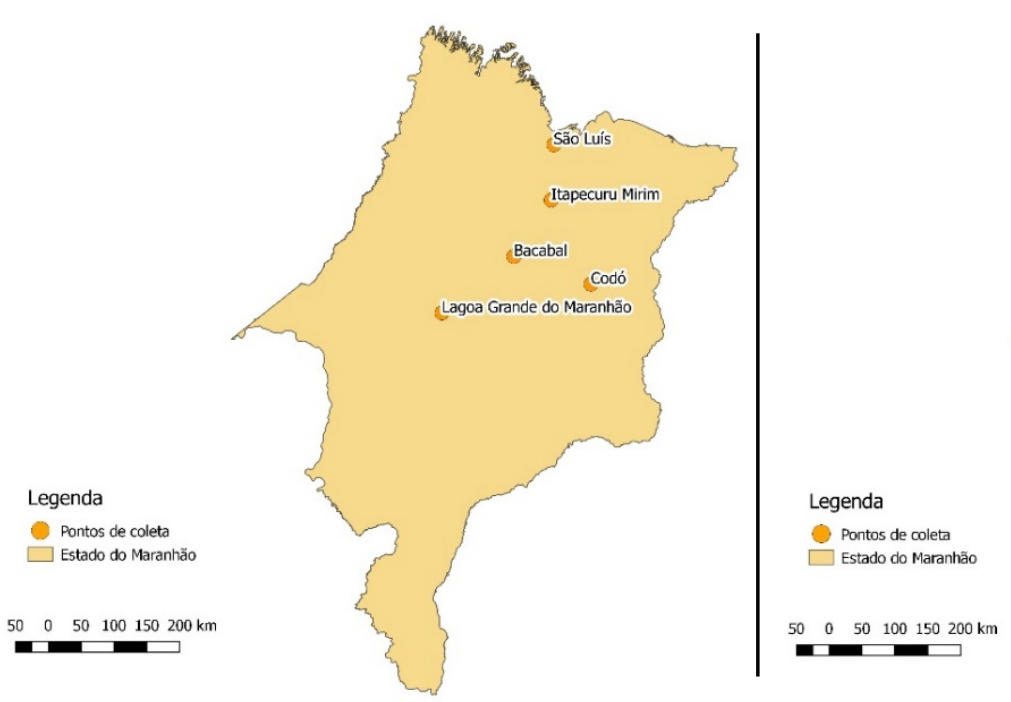

(A)

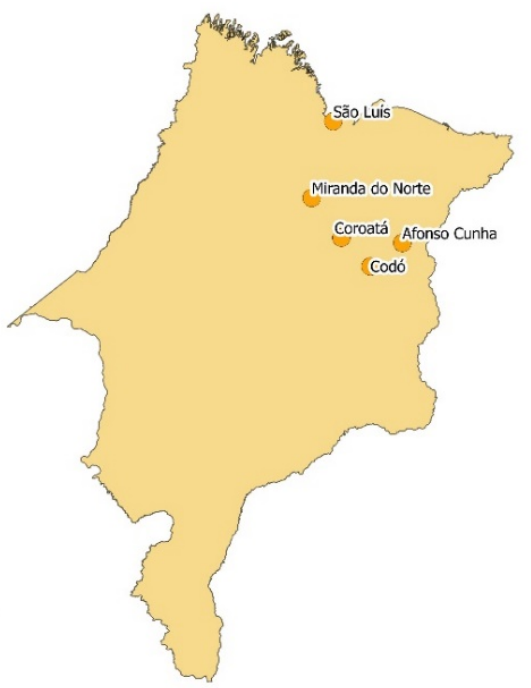

(B)

(A)Á esquerda está o mapa da Coleta 01, e (B) à direita, está o mapa da Coleta 02.

Fonte: Elaborado pela própria autora.

Para coleta das amotras foram utilizados os métodos de análise e amostragem da APHA (2005), NBR 9897 sobre a Preservação e técnicas de amostragem de efluentes líquidos e corpos receptores (ABNT, 1987b) e NBR 9898 sobre Planejamento de Amostragem de Efluentes Líquidos e Corpos Receptores (ABNT, 1987a). As características de cada município são detalhadas na Tabela 19, para a Coleta 01 e na Tabela 20, para a Coleta 02.

Tabela 19 - Parâmetros dos municípios selecionados para a coleta de amostra Ensaio 01.

\begin{tabular}{cccccccc}
\hline Município & $\begin{array}{c}\text { População } \\
\text { Estimada } \\
\text { (IBGE, } \\
\text { 2018) }\end{array}$ & $\begin{array}{c}\text { Densidade } \\
\text { Demográfica } \\
\text { (IBGE, } \\
\text { 2010) }\end{array}$ & $\begin{array}{c}\text { PIB per capita } \\
\text { (IBGE, 2010) }\end{array}$ & $\begin{array}{c}\text { IDHM } \\
\text { (IBGE, } \\
\text { 2010) }\end{array}$ & $\begin{array}{c}\text { Atendimento } \\
\text { por Solução } \\
\text { Individual } \\
\text { (ANA, 2013) }\end{array}$ & $\begin{array}{c}\text { Itice de } \\
\text { com Coleta e } \\
\text { Tratamento } \\
\text { (ANA, 2013; } \\
\text { SNIS;2017) }\end{array}$ \\
\hline São Luís & 1.094 .667 & $1.310,98$ & $\mathrm{R} \$$ & $26.154,00$ & 0,768 & $19,42 \%$ & $15,77 \%$ \\
\hline Itapecuru Mirim & 67.673 & 46,00 & $\mathrm{R} \$$ & $8.215,00$ & 0,599 & $36,99 \%$ & $0,00 \%$ \\
\hline Bacabal & 104.633 & 62,17 & $\mathrm{R} \$$ & $10.949,00$ & 0,651 & $95,00 \%$ & $0,00 \%$ \\
\hline Codó & 122.597 & 28,11 & $\mathrm{R} \$$ & $8.492,00$ & 0,595 & $60,00 \%$ & $40,00 \%$ \\
\hline $\begin{array}{c}\text { Lagoa Grande } \\
\text { do Maranhão }\end{array}$ & 11.320 & 15,22 & $\mathrm{R} \$$ & $6.103,00$ & 0,502 & $2,49 \%$ & $0,00 \%$ \\
\hline
\end{tabular}

Fonte: Adaptado de ANA, 2017; IBGE, 2017; PNUD, 2010; SNIS, 2018. 
Tabela 20 - Parâmetros dos municípios selecionados para a coleta de amostra Ensaio 02.

\begin{tabular}{ccccccc}
\hline Município & $\begin{array}{c}\text { População } \\
\text { Estimada } \\
\text { (IBGE, } \\
\text { 2018) }\end{array}$ & $\begin{array}{c}\text { Densidade } \\
\text { Demográfica } \\
\text { (IBGE, } \\
\mathbf{2 0 1 0}\end{array}$ & $\begin{array}{c}\text { PIB per } \\
\text { capita } \\
\text { (IBGE, } \\
\mathbf{2 0 1 0}\end{array}$ & $\begin{array}{c}\text { IDHM } \\
\text { (IBGE, } \\
\mathbf{2 0 1 0})\end{array}$ & $\begin{array}{c}\text { Índice de } \\
\text { Atendimento } \\
\text { por Solução } \\
\text { Individual } \\
\text { (ANA, 2013) }\end{array}$ & $\begin{array}{c}\text { Índice de } \\
\text { Atendimento } \\
\text { com Coleta e } \\
\text { Tratamento } \\
\text { (ANA, 2013; } \\
\text { SNIS; 2017) }\end{array}$ \\
\hline São Luís & 1.094 .667 & $1.310,98$ & $\mathrm{R} \$ 26.154,00$ & 0,768 & $19,42 \%$ & $15,77 \%$ \\
\hline Codó & 122.597 & 28,11 & $\mathrm{R} \$ 8.492,00$ & 0,595 & $60,00 \%$ & $40,00 \%$ \\
\hline Coroatá & 65.044 & 28,73 & $\mathrm{R} \$ 6.239,00$ & 0,576 & $21,89 \%$ & $0,00 \%$ \\
\hline Miranda do Norte & 28.001 & 82,11 & $\mathrm{R} \$ 16.764,00$ & 0,61 & $6,23 \%$ & $0,00 \%$ \\
\hline Afonso Cunha & 6.469 & 17,44 & $\mathrm{R} \$ 5.522,00$ & 0,529 & $0,12 \%$ & $0,00 \%$ \\
\hline
\end{tabular}

Fonte: Adaptado de ANA, 2017; IBGE, 2017; PNUD, 2010; SNIS, 2018.

Para a realização dos testes empíricos, foi coletado o inóculo (lodo anaeróbico), obtido em condições mesofílicas a partir de um reator UASB que trata águas residuais domésticas na cidade de São Paulo, tendo em vista que as análises foram realizadas em um laboratório da Universidade de São Paulo (USP) em São Paulo.

Após coletadas, as amostras foram congeladas durante sete dias para o transporte de São Luís até o Laboratório de Biocombustíveis do Instituto de Energia e Ambiente da Universidade de São Paulo (IEE-USP) para análise do potencial de geração de biogás por meio da aplicação da Determinação de Potencial Metanogênico (Biogas Methane Potential-BMP). Ao serem descongeladas, as amostras permaneceram 10 dias na geladeira enquanto foram feitas as análises laboratoriais.

Com relação à análise laboratorial, antes de se montar o ensaio, foram realizadas análises de Sólidos Totais, Fixos e Voláteis, DQO e pH para determinar a proporção de substrato e inóculo pela relação DQO sub/ SV ino (GONZÁLEZ-FERNÁNDEZ; GARCÍA-ENCINA, 2009) ou SV sub/ SV ino (LIU, GUANGQING et al., 2009). Todas as amostras foram analisadas para caracterização do efluente conforme os procedimentos da Tabela 21 realizados nos Laboratórios da USP, sendo os Sólidos Totais realizados no Laboratório de Saneamento do Departamento de Engenharia Hidráulica e Ambiental da Escola Politécnica (PHA/EPUSP) e a análise elementare na Central Analítica do Instituto de Química (IQ-USP). 
Tabela 21 - Métodos analíticos utilizados na caracterização dos resíduos

\begin{tabular}{ccc}
\hline PARÂMETRO & METODOLOGIA & AMOSTRAS \\
\hline $\begin{array}{c}\text { Sólidos totais, } \\
\text { voláteis e fixos }\end{array}$ & $\begin{array}{c}\text { APHA. Standard Methods for the Examination of } \\
\text { Water and Wastewater. 21 th ed. Washington, } \\
\text { 2005 (Method 2540-B e 2540-C). }\end{array}$ & $\begin{array}{c}\text { Amostras de efluente } \\
\text { doméstico e inóculo }\end{array}$ \\
\hline DQO solúvel & $\begin{array}{c}\text { APHA. Standard Methods for the Examination of } \\
\text { Water and Wastewater. 21 th ed. Washington, } \\
\text { 2005 (Method 5220-D).zz }\end{array}$ & $\begin{array}{c}\text { Amostras de efluente } \\
\text { doméstico e inóculo }\end{array}$ \\
$\begin{array}{c}\text { Análise } \\
\text { Elementar }\end{array}$ & Método de Pregl-Dumas & $\begin{array}{c}\text { Amostras de efluente } \\
\text { doméstico }\end{array}$ \\
\hline
\end{tabular}

Fonte: Elaborado pela própria autora.

A partir do resultado das análises das amostras coletadas foi possível realizar os cálculos de potencial téorico e realizar os ensaios laboratoriais.

\section{Cálculo potencial teórico}

Com relação a análise do potencial teórico de biogás, este foi calculado com base na análise elementar da Coleta 02, utilizando a fórmula de Boyle (1976), que se fundamenta nas seguintes fórmulas estequiométricas de Buswell e Mueller (1952) e O’Rourke (1968) para determinar o Potencial Bioquímico de Metano (BMP) (HUOKA et al., 2016). Utilizou-se também a fórmula de Potencial Metanogênico Teórico (TMP) (MOUKAZIS; PELLERA; GIDARAKOS, 2018; PELLERA; GIDARAKOS, 2016) para se comparar os resultados.

A Coleta 01 não foi utilizada, pois a quantidade de amostras foi insuficiente para realização da análise elementar, e consequentemente para a realização dos cálculos. Não se utilizou outras metodologias, como a baseada no número de habitantes e produção média per capita do Painel Intergovernamental de Mudanças Climáticas (IPCC) (CETESB, 2006; IPCC, 2006), tendo em vista que apenas uma parcela da população possui rede coletora, desta forma, a estimativa com base nos valores obtidos nas amostras se aproxima mais do potencial atual. Contudo, estudos como o de Cutrim (2012), utilizaram a metodologia do IPCC e estimam uma produção de 43,11 Gt $\mathrm{CH}_{4} /$ ano em São Luís, segundo a autora, valor suficiente para suprir 260 residências, e que poderia ser direcionado para secagem de lodo das ETEs, por exemplo.

A seguir são apresentadas as fórmulas utilizadas para os cálculos. A partir destas fórmulas foi caculado o potencial teórico de geração de biogás e de metano. 
- Buswell e Mueller (1952)

$$
\mathrm{C}_{n} \mathrm{H}_{a} \mathrm{O}_{b}+\left(n-\frac{a}{4}-\frac{b}{2}\right) \cdot \mathrm{H}_{2} \mathrm{O} \rightarrow\left(\frac{n}{2}-\frac{a}{8}+\frac{b}{4}\right) \cdot \mathrm{CO}_{2}+\left(\frac{n}{2}+\frac{a}{8}-\frac{b}{4}\right) \cdot \mathrm{CH}_{4}
$$

- O’Rourke (1968)

$$
\begin{aligned}
C_{n} H_{a} O_{b} N_{z}+ & \left(n-\frac{a}{4}-\frac{b}{2}+3 \frac{Z}{4}\right) \cdot H_{2} O \\
& \rightarrow\left(\frac{n}{2}-\frac{a}{8}+\frac{b}{4}+3 \frac{Z}{8}\right) \cdot \mathrm{CO}_{2}+\left(\frac{n}{2}+\frac{a}{8}-\frac{b}{4}-3 \frac{Z}{8}\right) \cdot \mathrm{CH}_{4}
\end{aligned}
$$

- Boyle (1976)

$$
\begin{aligned}
\mathrm{C}_{n} \mathrm{H}_{a} \mathrm{O}_{b} \mathrm{~N}_{z} S_{e} & +\left(n-\frac{a}{4}-\frac{b}{2}+3 \frac{z}{4}+\frac{e}{2}\right) \cdot \mathrm{H}_{2} \mathrm{O} \\
& \rightarrow\left(\frac{n}{2}-\frac{a}{8}+\frac{b}{4}+3 \frac{z}{4}+\frac{e}{4}\right) \cdot \mathrm{CO}_{2}+\left(\frac{n}{2}+\frac{a}{8}-\frac{b}{4}-3 \frac{z}{8}-\frac{e}{4}\right) \cdot \mathrm{CH}_{4}
\end{aligned}
$$

- Pellera; Gidarakos (2016)

$$
T M P\left[m L C H_{4 S T P} / g V S\right]=22.4 \cdot\left[\frac{\left(\frac{a}{2}+\frac{b}{8}+\frac{c}{4}+\frac{3 d}{8}+\frac{e}{4}\right)}{12 a+b+16 c+14 d+32 e}\right] .1000
$$

O cálculo de mols (n) de cada componente elementar das fórmulas acima foram obtidos a partir fórmula 5 da relação entre a massa molar (MM). A massa (M) do componente foi extraída através da análise elementar.

$$
N=\frac{M}{M M}
$$

Conforme indicado por D’AQUINO (2018), para o cálulo dos índices n, a, b e z, é necessária a normalização do nitrogênio, onde o índice de cada elemento deve ser dividido pelo $\mathrm{N}$ do nitrogênio. Desta forma, o índice do nitrogênio $(\mathrm{z})$ será 1.

Para estimar o valor de metano produzido, a partir do biogás obtido pelo cálculo do potencial téorico, considerou-se o valor médio de metano no biogás conforme a literatura, o qual varia entre 57\% a 65\% (RASI; VEIJANEN; RINTALA, 2007; SPIEGEL; PRESTON, 2003). 


\section{Cálculo do potencial empírico}

Com relação ao potencial empírico laboratorial, este foi analisado com base nos Ensaio 01 e 02, a partir das amostras da Coleta 01 e 02, respectivamente, e na coleta de dados do aferidor de vazão em São Luís.

O Ensaio 01 utilizou a metodologia para Determinação do Potencial Metanogênico em escala laboratorial do LACTEC. Nesta metodologia são utilizados reatores de $0,4 \mathrm{~L}$, e a proporção substrato e inóculo é de $60 \%$, 40\%, respectivamente. Desta forma, o Ensaio 01 apresentou as seguintes características, com a razão SV sub/ SV ino que variou entre 0,007 a 0,031, conforme Tabela 22.

Tabela 22 - Valores da quantidade de amostra nos biorreatores a partir da relação de sólidos voláteis - Ensaio 01.

\begin{tabular}{cccccc}
\hline & São Luís & Itapecuru & Codó & Bacabal & $\begin{array}{c}\text { Lagoa } \\
\text { Grande }\end{array}$ \\
\hline \multirow{2}{*}{ Substrato } & $240 \mathrm{~mL}$ & $240 \mathrm{~mL}$ & $240 \mathrm{~mL}$ & $240 \mathrm{~mL}$ & $240 \mathrm{~mL}$ \\
\cline { 2 - 6 } & $60,00 \%$ & $60,00 \%$ & $60,00 \%$ & $60,00 \%$ & $60,00 \%$ \\
\hline SV (mg/L) & 70,56 & 74,16 & 115,92 & 25,68 & 92,88 \\
\hline \multirow{2}{*}{ Inóculo } & $160 \mathrm{~mL}$ & $160 \mathrm{~mL}$ & $160 \mathrm{~mL}$ & $160 \mathrm{~mL}$ & $160 \mathrm{~mL}$ \\
\cline { 2 - 6 } & $40,00 \%$ & $40,00 \%$ & $40,00 \%$ & $40,00 \%$ & $40,00 \%$ \\
\hline SV (mg/L) & 3800 & 3800 & 3800 & 3800 & 3800 \\
\hline SV sub/SV ino & 0,019 & 0,02 & 0,031 & 0,007 & 0,024 \\
\hline
\end{tabular}

Fonte: Elaborado pela própria autora.

Considerando os valores de Sólidos Voláteis e com base em Liu et al. (2009), Al-Addous et al. (2018) e Haider et al. (2015), a razão ótima de Sólidos Voláteis entre substrato e inóculo é de $0,25 \mathrm{SV}$ sub/ SV ino. Desta forma, pela indicação de parte significativa dos artigos da relação $0,25 \mathrm{SV}$ sub/ SV ino como ótima, montou-se o Ensaio 02 com as amostras da Coleta 02, com as seguintes características da Tabela 23. 
Tabela 23 - Valores de quantidade de amostra nos biorreatores a partir da relação de sólidos voláteis - Ensaio 02.

\begin{tabular}{ccccccc}
\hline & São Luís & Coroatá & Codó & $\begin{array}{c}\text { Miranda } \\
\text { do Norte }\end{array}$ & $\begin{array}{c}\text { Afonso } \\
\text { Cunha }\end{array}$ & $\begin{array}{c}\text { Razão } \\
\text { SV sub/SV ino }\end{array}$ \\
\cline { 1 - 6 } Substrato & $381,99 \mathrm{~mL}$ & $381,99 \mathrm{~mL}$ & $372,40 \mathrm{~mL}$ & $367,79 \mathrm{~mL}$ & $383,22 \mathrm{~mL}$ & \\
\cline { 2 - 6 } & $95,50 \%$ & $95,50 \%$ & $93,10 \%$ & $91,95 \%$ & $95,80 \%$ & \\
\cline { 1 - 5 } SV (mg/L) & 106,96 & 106,96 & 163,86 & 191,25 & 99,64 & \multirow{2}{*}{0,25} \\
\cline { 1 - 5 } Inóculo & $18,01 \mathrm{~mL}$ & $18,01 \mathrm{~mL}$ & $27,60 \mathrm{~mL}$ & $32,21 \mathrm{~mL}$ & $16,78 \mathrm{~mL}$ \\
\cline { 2 - 5 } & $4,72 \%$ & $4,72 \%$ & $7,41 \%$ & $8,76 \%$ & $4,38 \%$ & \\
\hline SV (mg/L) & 427,82 & 427,82 & 655,43 & 765,00 & 398,55 \\
\hline
\end{tabular}

Fonte: Elaborado pela própria autora.

A preparação dos ensaios de biodigestão do Ensaio 01 e Ensaio 02 utilizou 12 bioreatores, cada, para realizar os testes de Biogas Methane Potential (BMP) utilizando o Sistema de Biodigestão e Biogás em Batelada (Ritter Apparatebau GmbH, Bochum, Alemanha), conforme o esquema da Figura 11. Dentre os reatores, 10 continham as cinco amostras em duplicatas, e dois foram utilizados como brancos. Ambos os ensaios tiveram duração média de 45 dias.

Figura 11 - Esquema representativo da coleta e análise das amostras dos ensaios.

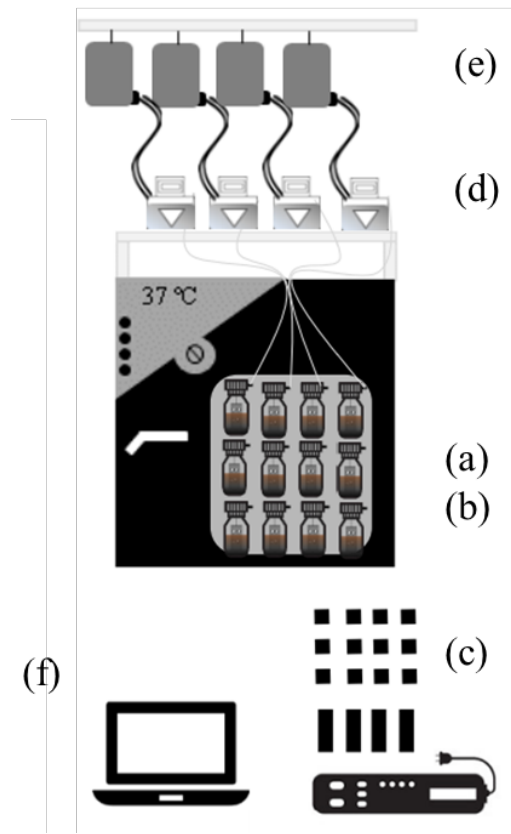

Legenda: Esquema do sistema para avaliação de potencial bioquímico de geração de metano (a) incubadora; (b) reatores anaeróbicos em lote em duplicata, usando a razão S / I de 1:4; (c) com sistema de agitação automática; (d) contadores de miligramas (Ritter); (e) bag de armazenamento de biogás e cromatografia em fase gasosa; (f) software Rigamo para aquisição e precisão de dados; Fonte: Elaborado pela própria autora. 
As condições de instalação foram descritas por Dandikas et al. (2015) com as modificações detalhadas a seguir. A digestão anaeróbica foi realizada em condições mesofílicas a $37^{\circ} \mathrm{C} \pm$ $1{ }^{\circ} \mathrm{C}$ dentro de uma incubadora. Cada biorreator individual ( $1 \mathrm{~L}$ feito de vidro) tinha um volume de trabalho de 0,4 L e um dispositivo de agitação, conforme Figura 12. O biogás produzido em cada câmara do reator foi transportado através de tubo flexível de PVC para milligascounters (Ritter, Alemanha) para registro do volume de gás. Para melhores resultados com tolerância mínima a erros, o Rigamo Software (Ritter, Alemanha) foi usado para aquisição de dados. Além disso, o inóculo sozinho foi testado como branco, no Ensaio 01, e como controle positivo no Ensaio 02, para determinar sua produção intrínseca de gás.

Figura 12 - Montagem do sistema para Determinação do Potencial Metanogênico.

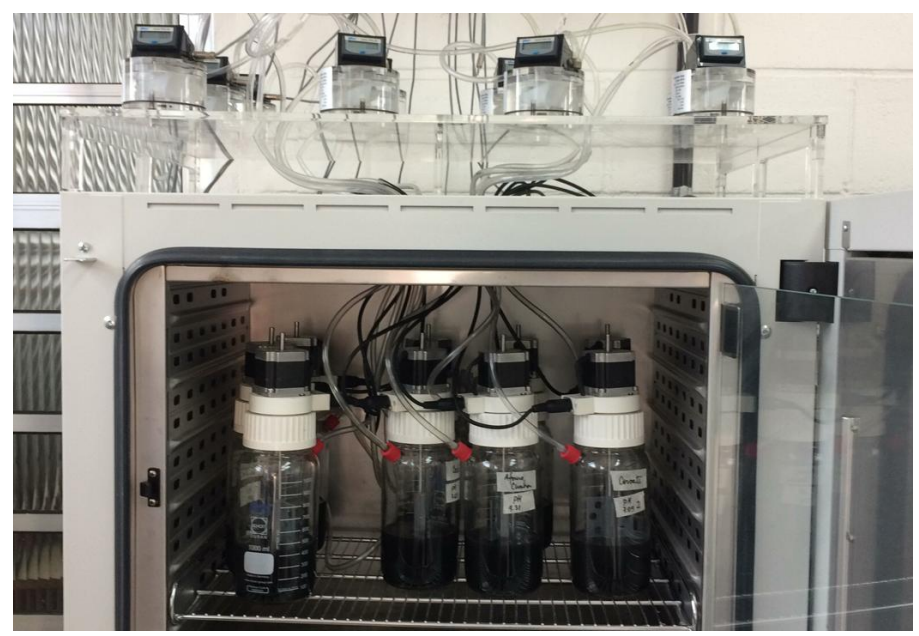

Fonte: Elaborado pela própria autora.

\section{Coleta dados de vazão}

Com relação ao potencial empírico mensurado em campo, foram utilizados equipamentos para medir a vazão de biogás na ETE Vinhais, em São Luís, que são aferidores de pressão configurados para medir a vazão de gás que sai dos reatores e são encaminhados até oflare. Os aferidores de pressão são modelo SITRANS P HART da Siemens como apresentado na Figura 13, a seguir. 
Figura 13 - Modelo aferidor de pressão/ vazão ETE Vinhais, São Luís.
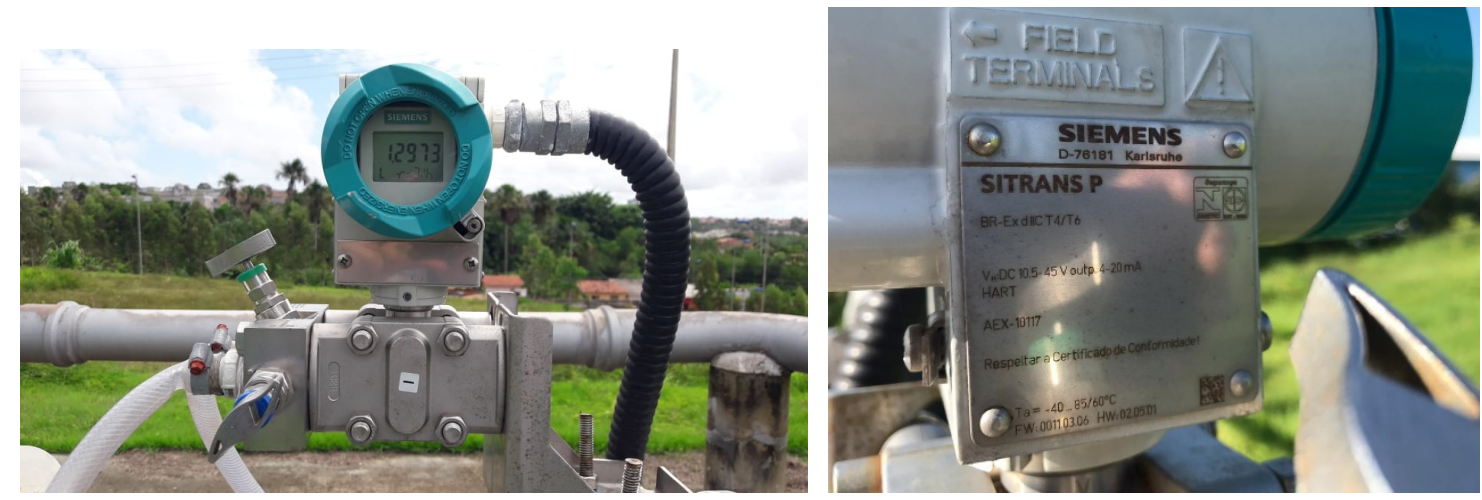

Fonte: Elaborado pela própria autora.

A seguir está apresentada a visão aérea da ETE Vinhais e a localização dos reatores e do flare, na Figura 14, onde apenas os Reatores 1, 2 e 3 estão em operação.

Figura 14 - Imagem de satélite da ETE Vinhais com localização dos reatores e do flare.

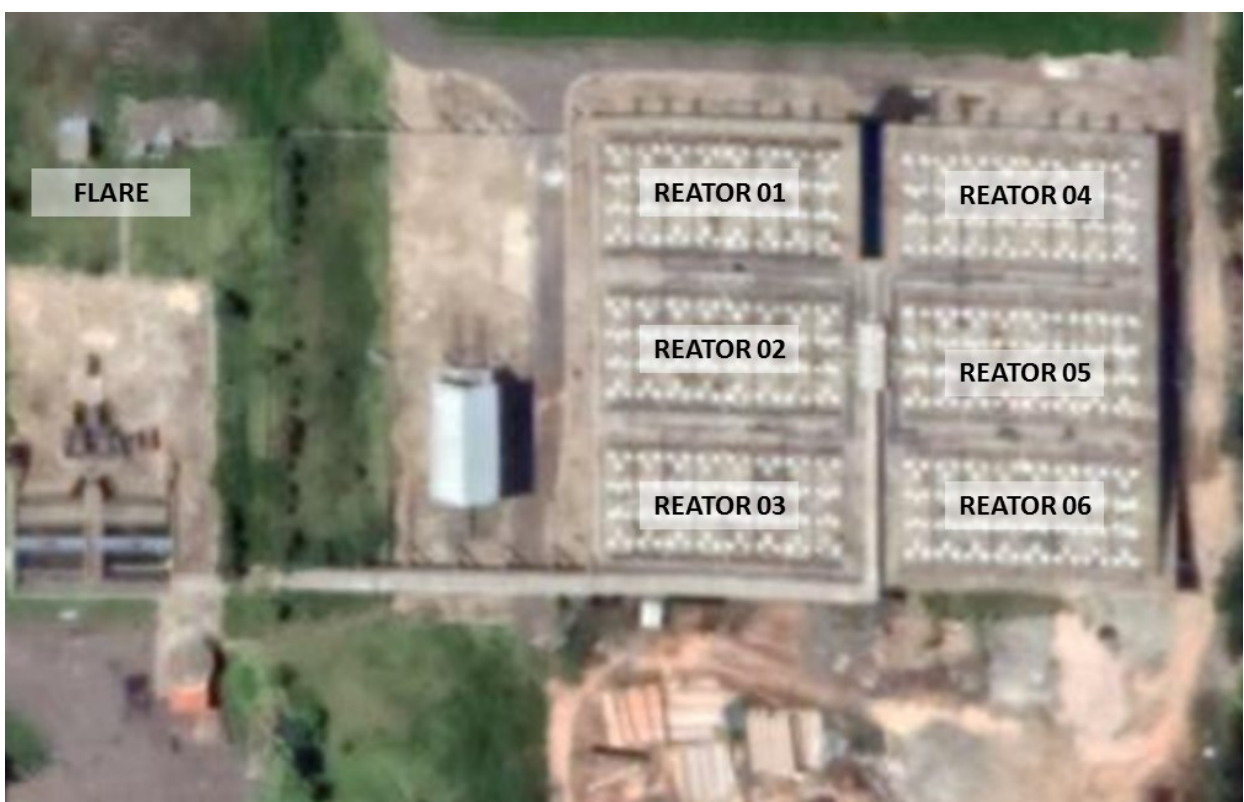

Fonte: Imagem adaptada de Google Earth.

A partir dos dados coletados foi possível comparar os valores com os resultados teóricos e dos Ensaios. 


\subsection{Estimativa do potencial teórico de produção de biogás}

Após a coleta, as amostras foram analisadas em laboratório para caracterização do substrato, e os resultados obtidos nas análises, seguem na Tabela 24, para o Ensaio 01 e na Tabela 25, para o Ensaio 02. O inóculo também foi analisado para a montagem do ensaio. Importante destacar que em dois munícipios, onde foi realizada a coleta, os quais possuíam apenas soluções domésticas como fossas sépticas e valas, apesar das tentantivas, não foi possível ter acesso a nenhuma fossa que pudesse ser aberta para coleta da amostra. Desta forma, foram coletadas em pontos de acúmulo das águas cinzas das casas que não eram destinadas para as fossas, por esta razão pode ter havido diferença no resultado destas amostras, e são resultados que não representam o esgoto doméstico em sua totalidade, prejudicando assim, a obtenção de resultados nos potenciais teóricos e empíricos.

Tabela 24 - Resultados da análise laboratorial das amostras da Coleta 01.

\begin{tabular}{ccccccc}
\hline 20/05/2019 & $\begin{array}{c}\text { São } \\
\text { Luís }\end{array}$ & $\begin{array}{c}\text { Itapecuru } \\
\text { Mirim }\end{array}$ & Codó & Bacabal & $\begin{array}{c}\text { Lagoa } \\
\text { Grande do } \\
\text { Maranhão }\end{array}$ & Inóculo \\
\hline DQO mgO 2 /L & 294 & 309 & 483 & 107 & 387 & 29400 \\
\hline ST mg/L & 500 & 520 & 770 & 890 & 830 & 39300 \\
\hline STF mg/L & 220 & 240 & 330 & 690 & 470 & 15550 \\
\hline STV mg/L & 280 & 280 & 440 & 200 & 360 & 23750 \\
\hline SV/ST & 0,56 & 0,54 & 0,57 & 0,22 & 0,43 & 0,6 \\
\hline
\end{tabular}

Fonte: Elaborado pela própria autora.

Tabela 25 - Resultados da análise laboratorial das amostras da Coleta 02.

\begin{tabular}{ccccccc}
\hline $\mathbf{1 5} / \mathbf{1 0} / \mathbf{2 0 1 9}$ & $\begin{array}{c}\text { São } \\
\text { Luís }\end{array}$ & Coroatá & Codó & $\begin{array}{c}\text { Miranda } \\
\text { do Norte }\end{array}$ & $\begin{array}{c}\text { Afonso } \\
\text { Cunha }\end{array}$ & Inóculo \\
\hline DQO mgO2 /L & 294 & 335 & 515 & 430 & 428 & 29400 \\
\hline ST mg/L & 500 & 880 & 880 & 2020 & 1360 & 39300 \\
\hline STF $\mathbf{~ m g / L ~}$ & 220 & 600 & 440 & 1500 & 1100 & 15550 \\
\hline STV mg/L & 280 & 280 & 440 & 520 & 260 & 23750 \\
\hline $\mathbf{S V / S T}$ & 0,56 & 0,32 & 0,5 & 0,26 & 0,19 & 0,6 \\
\hline $\mathbf{C ~ ( \% )}$ & 18,94 & 11,2 & 23,94 & 8,73 & 13,01 & - \\
\hline $\mathbf{H ~ ( \% )}$ & 3,43 & 2,14 & 3,62 & 1,98 & 1,7 & - \\
\hline $\mathbf{N ~ ( \% )}$ & 2,08 & 1,23 & 1,96 & 0,63 & 0,79 & - \\
\hline $\mathbf{S ~ ( \% )}$ & 2,43 & 4,07 & 2,07 & 4,06 & 2,72 & - \\
\hline $\mathbf{p H}$ & 7,03 & 7,09 & 7,03 & 7,47 & 7,22 & - \\
\hline $\mathbf{C} / \mathbf{N}$ & 9,11 & 9,11 & 12,21 & 13,86 & 16,46 & \\
\hline
\end{tabular}

Fonte: Elaborado pela própria autora. 
Os resultados demonstram que todas as amostras apresentam um valor de DQO abaixo da média de 600mg/L (VON SPERLING, 1996), contudo, próximo de 449,7mg/L, como indicado por Silva (2015) para esgoto doméstico, que pode variar entre 400-800mg/L. Com relação ao valor de Sólidos Totais, este pode variar entre 700-1350 mg/L, para Sólidos Fixos a faixa é de 340-650 mg/L e para Sólidos Voláteis é de 360-700 mg/L (SILVA, CARLOS ERNANDO, 2020). Desta forma, percebe-se, que ao considerar o valor médio obtido por Silva (2015), os valores de DQO se encontram dentro da média, mas apresentam baixa concentração de Sólidos nos efluentes, principalmente na Coleta 01 . Isto deve ocorrer, pois a Coleta 01 foi realizada em um período de chuvas intensas no Estado.

Importante destacar que a Coleta 01 não apresenta resultados para as análises de $\mathrm{C}, \mathrm{H}, \mathrm{N}, \mathrm{S}$ e $\mathrm{C} / \mathrm{N}$, pois o montante de amostra desta primeira Coleta não foi suficiente para estas análises, aspecto que foi corrigido para a Coleta 02 . Além disto, a análise de $\mathrm{pH}$, também não foi realizada na Coleta 01.

Para calcular o potencial teórico de geração de biogás a partir das amostras coletadas conforme descrito acima, foi utilizada a fórmulas de Boyle (1976). Apesar da fórmula de Boyle (1976) abranger o enxofre nos cálculos, os valores de produção de biogás e metano para ambas as fórmulas de O’Rourke (1968) e Boyle (1976) foram muito similares.

A determinação do valor de Oxigênio na amostra foi feita de forma indireta, por meio da diferença de C,H,N e S nos sólidos voláteis (FIRMO, 2013), contudo com o baixo percentual dos elementos $\mathrm{C}, \mathrm{H}, \mathrm{N}$ e $\mathrm{S}$, o valor do oxigênio ficaria muito elevado. Desta forma, considerouse o valor utilizado na literatura, de aproximadamente 33\% (D'AQUINO, 2018; FIRMO, 2013).

Os resultados dos balanços estequiométricos da fórmula de Boyle (1976), para a amostra de cada município, são apresentados a seguir. Houve alguma inconsistência nos cálculos de geração de dióxido de carbono e metano, pois o balanço indica consumo negativo para a água na maioria dos municípios, com exceção de Codó.

Afonso Cunha: $\mathrm{C}_{19,205} \mathrm{H}_{29,905} \mathrm{O}_{37,598} \mathrm{~N} \mathrm{~S}_{1,504}-5,5529 \mathrm{H}_{2} \mathrm{O}=16,0074 \mathrm{CO}_{2}+3,1977 \mathrm{CH}_{4}$

Codó: $\mathrm{C}_{14,244} \mathrm{H}_{25,667} 0_{15,142} \mathrm{~N} \mathrm{~S}_{0,460}+1,2365 \mathrm{H}_{2} \mathrm{O}=8,1893 \mathrm{CO}_{2}+6,0548 \mathrm{CH}_{4}$

Coroatá: $\mathrm{C}_{10,619} \mathrm{H}_{24,178} \mathrm{O}_{24,129} \mathrm{~N} \mathrm{~S}_{1,671}-5,9047 \mathrm{H}_{2} \mathrm{O}=9,1121 \mathrm{CO}_{2}+1,5868 \mathrm{CH}_{4}$

Miranda do Norte: $\mathrm{C}_{16,160} \mathrm{H}_{43,676} 0_{47,109} \mathrm{~N} \mathrm{~S}_{2,812}-16,1576 \mathrm{H}_{2} \mathrm{O}=15,4756 \mathrm{CO}_{2}+0,6844 \mathrm{CH}_{4}$

São Luís: $\mathrm{C}_{10,619} \mathrm{H}_{22,917} 0_{14,269} \mathrm{~N} \mathrm{~S}_{0,510}-1,2392 \mathrm{H}_{2} \mathrm{O}=6,4157 \mathrm{CO}_{2}+4,1044 \mathrm{CH}_{4}$ 
Observa-se que em comparação com os dados obtidos por D’Aquino (2018) em seus experimentos, o único município que se aproxima dos valores da análise elementar é Codó, e o restante apresenta valores de Carbono (carga orgânica) mais baixos. Supõe-se então que este aspecto pode impactar diretamente nos resultados do balanço estequiométrico do potencial de biogás. Por esta razão, talvez seja necessário concentrar as amostras, para verificar se o aumento da concentração de efluente doméstico poderia melhorar estes resultados.

Apesar da inconsistência no balanço estequiométrico, obteu-se a estimativa de produtividade de biogás para cada município, considerando a biodegradabilidade dos resíduos, tendo em vista que resíduos como efluentes domésticos são altamente biodegradáveis (D’AQUINO, 2018; FIRMO, 2013). Na Tabela 26 estão apresentados os valores obtidos para a produtividade teórica de biogás por cada amostra dos municípios referentes à Coleta 02, utilizando a fórmula de Boyle (1976). Utilizou-se o valor de 43\% para a biodegradabilidade do resíduo (D’AQUINO, 2018). Observa-se novamente o destaque para Codó, com valores mais elevados de biogás e metano.

Tabela 26 - Produtividade téorica de biogás por município (BMP) - Ensaio 02.

\begin{tabular}{ccccccc}
\hline \multirow{2}{*}{ Municípios } & \multicolumn{3}{c}{ PRODUTIVIDADE TEÓRICA } & \multicolumn{2}{c}{ COM BIODEGRADABILIDADE } \\
& \multicolumn{3}{c}{$\left(\mathrm{Nm}^{3} /\right.$ tonMS $)$} & & \multicolumn{3}{c}{$\left(\mathrm{Nm}^{3} /\right.$ tonMS $)$} \\
\hline & $\mathrm{m}^{3} \mathrm{CH} 4$ & $\mathrm{~m}^{3} \mathrm{CO} 2$ & biogás & $\mathrm{m}^{3} \mathrm{CH} 4$ & $\mathrm{~m}^{3} \mathrm{CO} 2$ & biogás \\
\hline Afonso Cunha & 97,989 & 426,372 & 524,360 & 42,135 & 183,340 & 225,475 \\
\hline Codó & 326,934 & 425,619 & 752,554 & 140,582 & 183,016 & 323,598 \\
\hline Coroatá & 83,736 & 376,323 & 460,059 & 36,006 & 161,819 & 197,825 \\
\hline Miranda do Norte & 33,124 & 350,887 & 384,011 & 14,243 & 150,881 & 165,125 \\
\hline São Luís & 258,652 & 388,341 & 646,994 & 111,221 & 166,987 & 278,207 \\
\hline
\end{tabular}

Fonte: Elaborado pela própria autora.

Utilizando a fórmula de Pellera; Gidarakos (2016) os resultados estão apresentados na Tabela 27.

Tabela 27. Produtividade téorica de biogás por município (TMP) - Coleta 02

\begin{tabular}{cc}
\hline Município & $\begin{array}{c}\text { TMP } \\
\text { (ml CH4/g VS) }\end{array}$ \\
\hline Afonso Cunha & $-76,706$ \\
\hline Codó & 65,165 \\
\hline Coroatá & $-112,302$ \\
\hline Miranda do Norte & $-145,382$ \\
\hline São Luís & 0,923 \\
\hline
\end{tabular}

Fonte: Elaborado pela própria autora. 
Observa-se que para ambas as fórmulas, o município de Codó apresenta valores de biogás mais elevados, em relação aos outros municípios, seguido de São Luís. Estes valores podem estar relacionados à maior quantidade de Carbono (carga orgânica) nas amostras destes dois municípios. Desta forma, observa-se que a maior concentração de Carbono interfere de forma significativa no potencial de geração de biogás. Observa-se principalmente que apenas a partir do valor de Carbono acima 19\% existe potencial de geração de biogás.

Com relação aos valores de produtividade de biogás diário em cada sistema, utilizou-se a vazão média de cada sistema para estimar o valor de biogás e metano gerado em cada local. No caso de Miranda do Norte e Afonso Cunha foi necessário estimar a vazão, com base nos valores da população e vazão dos outros municípios, tendo em vista que não se tinha esta informação disponível. Os resultados seguem conforme a Tabela 28 abaixo:

Tabela 28 - Produtividade téorica de biogás por município por dia - Coleta 02.

\begin{tabular}{lcccccc}
\hline & \multicolumn{3}{c}{ PRODUTIVIDADE TEÓRICA $\mathbf{( \mathbf { N m } ^ { 3 } / \mathbf { d } )}$} & \multicolumn{2}{c}{ COM BIODEGRADABILIDADE } \\
& $\mathrm{m}^{3} \mathrm{CH} 4$ & $\mathrm{~m}^{3} \mathrm{CO} 2$ & biogás & $\mathrm{m}^{3} \mathrm{CH} 4$ & $\mathrm{~m}^{3} \mathrm{CO} 2$ & biogás \\
\hline Afonso Cunha & 309,08 & 1539,16 & 1848,24 & 132,90 & 661,84 & 794,74 \\
\hline Codó & 16685,44 & 22450,12 & 39135,57 & 7174,74 & 9653,55 & 16828,29 \\
\hline Coroatá & 24,42 & 146,94 & 171,36 & 10,50 & 63,18 & 73,69 \\
\hline Miranda do Norte & 171,12 & 3849,21 & 4020,33 & 73,58 & 1655,16 & 1728,74 \\
\hline São Luís & 940,64 & 1485,27 & 2425,92 & 404,48 & 638,67 & 1043,15 \\
\hline
\end{tabular}

Fonte: Elaborado pela própria autora.

Observa-se que a produção de biogás, e consequentemente de metano, é significativamente maior em Codó, apesar da vazão afluente na ETE ser de apenas 22,8 L/s, enquanto que em São Luís a vazão é de $70 \mathrm{~L} / \mathrm{s}$. Mostrando mais uma vez a influência da concentração de Carbono (carga orgânica) na produção de biogás, como aponta a literatura.

Conforme explicado anteriormente, tendo em vista que o volume de amostras coletadas para a Coleta 01 não foi sufuciente para realizar as análises elementares, consequentemente não foi possível realizar os cálculos de potencial teórico. Desta forma, apenas a Coleta 02 foi analisada neste quesito.

Em comparação a experimentos como de Cabral (2016), proveniente do projeto PROBIOGÁS, os quais tiveram a produção de biogás variando de 272 a 3307 Nm³/d em quatro ETEs espalhadas nas regiões Sul, Sudeste e Centro-Oeste do Brasil, percebe-se que a variação do potencial de aproveitamento de biogás com biodegradabilidade foi similar, com exceção do 
município de Codó, onde o potencial de produção é significativamente mais elevado. No estudo de Menezes (2016), realizado em condomínios residenciais do Programa Minha Casa, Minha Vida, como no caso das amostras dos municípios de Miranda e Coroatá, observa-se que Coroatá se aproxima do valor obtido de $58,78 \mathrm{Nm}^{3} / \mathrm{d}$, energia suficiente para auxiliar com redução de custos com energia elétrica do condomínio, na sua iluminação, por exemplo. Miranda do Norte, neste caso, apresenta uma distorção significativa, pois a ETE não estava em funcionando por um longo período de tempo, ocasionando uma possível concentração do efluente, e consequentemente, de matéria orgânica.

\subsection{Estimativa do potencial empírico de produção de biogás}

\section{Ensaio 01 e 02}

Conforme descrito na metodologia, no Ensaio 01 utilizou-se o procedimento do LACTEC. Com este procedimento, foi colocado $160 \mathrm{~mL}$ de inóculo e $240 \mathrm{~mL}$ de substrato nos reatores, independente da razão entre sólidos contidos no substrato e no inóculo. Considerando-se o percentual de sólidos do mesmo inóculo utilizado no Ensaio 02, a razão de sólidos nos reatores variou entre 0,007 e 0,031 SV sub/ SV ino. Neste caso, os resultados de geração de biogás não apresentaram resultados significativos, como é apresentado na Tabela 29, onde o Volume medido de biogás não atingiu mais que 0,1 ltr.

Tabela 29 - Registros sobre a produção de biogás das amostras coletadas Ensaio 01.

\begin{tabular}{ccc}
\hline Amostras & Data Início & Volume [ltr] \\
\hline Branco 1 & $20 / 05 / 2019$ & 0,003 \\
\hline Branco 2 & $20 / 05 / 2019$ & 0,000 \\
\hline São Luís 1 & $20 / 05 / 2019$ & 0,000 \\
\hline São Luís 2 & $20 / 05 / 2019$ & 0,104 \\
\hline Itapecuru 1 & $20 / 05 / 2019$ & 0,062 \\
\hline Itapecuru 2 & $20 / 05 / 2019$ & 0,000 \\
\hline Codó 1 & $20 / 05 / 2019$ & 0,006 \\
\hline Codó 2 & $20 / 05 / 2019$ & 0,000 \\
\hline Bacabal 1 & $20 / 05 / 2019$ & 0,006 \\
\hline Bacabal 2 & $20 / 05 / 2019$ & 0,000 \\
\hline Lagoa Grande 1 & $20 / 05 / 2019$ & 0,061 \\
\hline Lagoa Grande 2 & $20 / 05 / 2019$ & 0,000 \\
\hline
\end{tabular}

Fonte: Elaborado pela própria autora. 
Tendo em vista que os resultados do Ensaio 01, não foram satisfatórios, foi necessário realizar o Ensaio 02, com o intuito de encontrar melhores resultados, onde modificou-se as proporções substrato inóculo. A revisão da literatura indica artigos que utilizam substratos como efluentes domésticos, restos de alimento e resíduos vegetais em seus ensaios e apontam que razões muito baixas ou acima de $0,46 \mathrm{SV}$ sub/ SV ino, prejudicam a produção de biogás, exceto Koch et al. (2016), que utilizou a razão de 0,5 SV sub/ SV ino, para o ensaio utilizando como substrato resíduos de alimento e efluente doméstico. Desta forma, no Ensaio 02, utilizouse o mesmo sistema, contudo, foi alterada a proporção de substrato e inóculo, conforme recomendado por Liu et al. (2009), Al-Addous et al. (2018) e Haider et al. (2015), onde a razão ótima de Sólidos Voláteis entre substrato e inóculo é de 0,25 SV sub/ SV ino.

Como resulados, o Ensaio 02 também apresentou uma produção pouco significativa e em apenas 2 amostras, como apresentado na Tabela 30, a seguir.

Tabela 30 - Registros sobre a produção de biogás das amostras coletadas Ensaio 02.

\begin{tabular}{ccc}
\hline Amostras & Data Início & Volume [Itr] \\
\hline Controle positivo 1 & $24 / 10 / 2019$ & 1,719 \\
\hline Controle positivo 2 & $24 / 10 / 2019$ & 1,719 \\
\hline Afonso 1 & $24 / 10 / 2019$ & 0,000 \\
\hline Afonso 2 & $24 / 10 / 2019$ & 0,028 \\
\hline Codó 1 & $24 / 10 / 2019$ & 0,000 \\
\hline Codó 2 & $24 / 10 / 2019$ & 0,000 \\
\hline Coroatá 1 & $24 / 10 / 2019$ & 0,000 \\
\hline Coroatá 2 & $24 / 10 / 2019$ & 0,000 \\
\hline Miranda 1 & $24 / 10 / 2019$ & 0,003 \\
\hline Miranda 2 & $24 / 10 / 2019$ & 0,000 \\
\hline São Luís 1 & $24 / 10 / 2019$ & 0,000 \\
\hline São Luís 2 & $24 / 10 / 2019$ & 0,000
\end{tabular}

Fonte: Elaborado pela própria autora.

Conforme apresentado, os resultados dos Ensaios 01 e 02 não demonstraram potencial dos efluentes domésticos para geração de biogás. Contudo, existem diversos fatores como o volume de amostra, a coleta, o condicionamento, entre outras variáveis que podem ter contribuído para o resultado obtido. Além disto, a metodologia conta com reduzido número e quantidade de amostras, que pode influenciar na baixa carga orgânica das amostras. A partir da análise do potencial teórico se observa também o baixo teor de Sólidos e DQO, em relação a outros valores encontrados na literatura. 
Dentre os municípios escolhidos estão aqueles operados e não operados pela CAEMA, e que possuem a utilização de diferentes tecnologias. Com relação ao histórico de caracterização dos parâmetros dos efluentes nos municípios escolhidos, apenas em São Luís os efluentes são analisados antes e após o tratamento quanto à Demanda Bioquímica de Oxigênio (DBO), Demanda Química de Oxigênio (DQO), Série de Sólidos Totais, Colimetria, Fósforo, Nitrogênio amoniacal e total, óleos e graxas, Oxigênio Dissolvido e pH. No caso de Codó, Coroatá e Miranda, estas ETEs não possuem histórico de análises laboratoriais, e a coleta foi realizada no ponto de concentração do esgoto, como na elevatória ou no local de chegada do esgoto na ETE. Não foi possível coletar em um ponto pós tratamento. No caso de Lagoa Grande do Maranhão e Afonso Cunha, cidades que possuem um dos menores IDH do Estado, tentouse coletar nas fossas sépticas, mas não foi possível, então as amostras foram coletadas em um ponto com efluente acumulado na rua. Neste caso, a carga orgânica foi proveniente de outros efluentes das casas, que não do vaso sanitário ou chuveiro.

O Estado do Maranhão apresenta diversas adversidades com relação ao setor de saneamento, e principalmente com relação ao esgotamento sanitário. Devido ao desconhecimento e infraestrutura precária em determinados locais, em certos casos, águas pluviais são direcionadas para as tubulações de esgotamento sanitário, e no caso de São Luís, alguns poços de visita ficam submersos devido a elevação da maré, encaminhando este volume adicional de água salobras para o sistema de tratamento. Contudo, mesmo durante o período seco, como da Coleta 02, em Outubro, observa-se ainda a elevada diluição do esgoto, dificultando a geração de biogás.

Considerando que resultados do Ensaio 01 e Ensaio 02 não foram expressivos para gerar uma curva de geração de biogás, buscou-se coletar dados de vazão de biogás dos reatores e flare da ETE Vinhias, pois, observou-se que a ETE também possui aferidores de vazão de biogás nos reatores e no flare, e estes dados poderiam apontar informações mais próximas da realidade. $\mathrm{O}$ fato de não se obter valores para o potencial empírico de biogás, pode indicar diversos aspectos relacionados, desde às características da própria amostra, até às condições da coleta, armazenamento e montagem do ensaio, conforme mencionado anteriormente.

\section{Coleta dados de vazão}

O acompanhamento da vazão de biogás na ETE Vinhais foi realizado na saída dos 3 reatores e na entrada do flare, onde os equipamentos estão instalados. A medição foi realizada 2 vezes ao dia, durante o período de 30 dias, de 19/03/2020 a 19/04/2020. 
Os equipamentos possuem calibragens diferentes, por esta razão apresentam valores variados. Na Tabela 31 são apresentados os valores médios obtidos nos medidores de vazão no período. O Reator 2 apresentou problemas desde o início do período de medição. Com relação aos valores obtidos nos outros reatores, precisam ser parametrizados, de forma a atingir um valor que seja somado e comparado ao valor obtido no flare.

Tabela 31 - Valores médios obtidos nos medidores de vazão da ETE Vinhais.

\begin{tabular}{lcccc}
\hline & Flare & Reator 1 & Reator 2 & Reator 3 \\
\hline Vazão média $\left(\mathbf{m}^{\mathbf{3}} \mathbf{h}\right)$ & 1,284 & 1,296 & error & 278,978
\end{tabular}

Fonte: Elaborado pela própria autora.

Como mencionado, o Reator 2 estava com problemas para registro de vazão, possivelmente devido ao baixo volume de biogás, ou por problemas no equipamento. No Reator 3, o medidor está calibrado para um range diferente dos outros medidores, com o nível de detecção até $300 \mathrm{~m}^{3} / \mathrm{h}$, enquanto os outros estão com nível de detecção até $7 \mathrm{~m}^{3} / \mathrm{h}$. Além disto, o Reator 3 apresentou variações significativas de valores no período, indicando possível problema na calibração. Desta forma, considerou-se apenas os resultados do flare e do Reator 1 que estão na mesma base de comparação.

Analisando os valores de vazão de biogás obtido no flare e no Reator 1, sabe-se que o valor obtido no flare deveria ser a somatória do valor registrado em todos os reatores, contudo, percebeu-se que o valor obtido no flare está muito próximo do valor do Reator 1 , indicando possivelmente o escape de biogás nos reatores e na tubulação até o flare. Logo, assim como apontado pelo relatório da consultoria contratada pela CAEMA, é necessário aplicar produtos químicos na tubulação, bem como internamente no reator, para evitar sua corrosão, pois a formação de ácido tem prejudicado a retenção do biogás, e a detecção mais precisa pelos medidores de vazão.

\subsection{Discussão do potencial de biogás}

A coleta de amostras em diversos municípios foi relevante na compilação das informações sobre a diferente realidade dos municípios sobre a situação do esgotamento sanitário, como por exemplo, com relação ao controle da qualidade do efluente antes e após o tratamento. No que se refere aos resultados de potencial de biogás, o resultado de cada município foi diferente 
apenas para o potencial teórico, já os resultados do potencial empírico não apresestaram diferença significativa.

No cálculo do potencial de biogás teórico, observa-se que ambas as fórmulas, tanto Boyle (1976) como Pellera e Gidarakos (2016) apontam que o município de Codó e São Luís apresentam valores mais relevantes de geração de biogás. Ao analisar os resultados da análise elementar, percebe-se que isto ocorre devido à maior concentração de Carbono (carga orgânica) nestas amostras. Observa-se também que houve uma inconsistência no balanço estequiométrico do restante dos municípios, aspecto que pode estar atrelado a não viabilidade de geração de biogás por estas amostras.

Com relação ao potencial empírico, os valores de biogás não foram significativos, e foram similares para todas as amostras, não apresentando diferenças dentre os municípios escolhidos. Os motivos dos resultados não conseguirem produzir um valor significativo de biogás, podem estar atrelados à baixa concentração das amostras, além de volume pouco expressivo de amostra utilizado nos experimentos, assim como o limite do nível de detecção do equipamento, dentre outros aspectos. Desta forma, para se obter valores de biogás, poderá ser necessário concentrar o efluente e também utilizar maiores quantidades de amostra em próximos experimentos.

Importante destacar também que os motivos da não detecção no ensaio também podem estar atrelados às condições da coleta, armazenamento e montagem do ensaio, que precisam ser analisados criteriosamente também. $\mathrm{O}$ ideal seria que as análises tivessem sido realizadas o mais breve possível, sem necessidade de congelamento e deslocamento para outro Estado.

No que se refere ainda aos resultados empíricos, tendo em vista que apenas o município de São Luís possui instrumento para o monitoramento da vazão de biogás produzido, apenas neste município foi possível fazer a comparação dos valores teóricos com os resultados dos flares. Ao comparar o potencial teórico e empírico, a partir dos cálculos do potencial teórico para o município de São Luís e os valores apresentados pelos medidores na ETE Vinhais em São Luís, observa-se que o potencial teórico indica o valor diário médio de produção de biogás, considerando a biodegradabilidade do gás, de 1043,92 Nm³ , ou seja, em condições de pressão 1 atm, à temperatura de $0^{\circ} \mathrm{C}$ e com $0 \%$ de umidade relativa, seria este o valor estimado. Contudo, pelo valor médio de $1,284 \mathrm{~m}^{3} / \mathrm{h}$ registrado pelo medidor no flare, percebe-se que a produção pode ser muito mais baixa que o valor teórico. Os motivos podem estar relacionados ao desempenho dos reatores, à dissolução deste gás no efluente, ao escape dos gases, transferência do biogás da superfície da água no reator para a atmosfera, e às condições de temperatura, pressão e umidade relativa diferentes, (LIMA; PASSAMANI, 2012). Estudos estimam que a perda na geração real de metano, em relação ao potencial teórico, pode ser da 
ordem de 50\% (SOUZA, 2010). Existe a possibilidade ainda de problemas na calibragem do medidor, que tem sido visto junto à empresa responsável.

De uma maneira geral, é necessário ver os principais aspectos que podem ter influenciado para a obtenção destes dados, para que as incertezas se reduzam em próximos experimentos.

6. Discussão dos resultados da pesquisa

No presente estudo foram levantadas diversas informações que serão analisadas neste capítulo, de forma a sintetizar e confrontar o conteúdo abordado nas seções anteriores.

Na revisão de literatura foi possível extrair a dimensão do déficit de esgotamento sanitário e ao mesmo tempo da oportunidade de expansão do mercado de recuperação energética a partir do esgoto doméstico país. Os dados apontam que as plantas para estas soluções estão localizadas predominantemente nas regiões Sul e Sudeste do país, onde existem ETEs com aproveitamento do efluente e do lodo de esgoto, para geração de energia. A literatura apresenta ainda que, dentre a variedade de experiências mencionadas sobre recuperação energética a partir de resíduos, existe um conjunto de soluções promissoras para recuperação energética de efluentes domésticos que servem como alternativas para viabilizar a implantação e operação de mais estações de tratamento de efluentes, por meio da redução de custos com energia ou com a geração de excedente energético.

Os reatores se destacam como soluções promissoras, como reatores UASB ou Biorretores de Membrana, por apresentarem desempenho significativo para tratamento do efluente e recuperação energética através do biogás. Ressalta-se apenas que, por se tratarem de tecnologias novas, os Biorreatores ainda são alternativas de elevado custo, e que ao contrário das outras tecnologias, não apresentam economia de escala. Existem ainda a solução de Células Combustíveis Microbianas que tem sido estudada para aplicação mais expressiva no mercado.

No que tange soluções como lagoas e lodos ativados, estes estão difundidos no país, contudo apresentam mais dificuldades para recuperação de energia a partir do biogás, a qual pode ser realizada apenas pela digestão do lodo unicamente ou misturado com outros resíduos, por codigestão. Existe também a possibilidade de recuperar energia do lodo a partir do uso da incineração, mas é uma tecnologia de elevado custo, sendo inviável para pequenas plantas. Neste caso, é possível utilizar o lodo como fertilizante por meio da compostagem, considerando a Resolução CONAMA No 430/2011. Por fim, parte dos artigos indicam que é importante considerar aspectos que influenciam a adoção destas soluções por parte dos municípios, 
considerando suas características, principalmente a nível técnico, econômico, territorial, social e ambiental, e estes aspectos impactam diretamente na viabilidade da implantação da solução.

Com a perspectiva da experiência internacional e do cenário nacional sobre o tema, a pesquisa aprofundou a análise da situação do esgotamento sanitário no Estado Maranhão. A partir do panorama geral atual, foi possível ter uma visão preliminar e mais acurada para se pensar estratégias de impulsionar a melhoria do cenário deficitário do esgotamento sanitário, e do aproveitamento energético no Estado. Com a caracteriazação dos principais atores do setor de saneamento, é possível pensar os arranjos para uma política pública que englobe atores do setor público e privado, tendo em vista as novas condicionantes impostas pelo novo Marco Regulatório que exigirá esforço, investimento e melhoria na prestação do serviço por parte de todos os lados.

O levantamento da infraestrutura permitiu comparar os dados apresentados nos bancos de informações existentes, atualizar e acrescentar dados mais detalhados, aprofundar o entendimento da situação, e agrupar municípios similares para facilitar a análise a nível estadual. Logo, o estudo de caso, teve o intuito foi de fornecer subsídios para estratégias de adaptar ou criar instalações que possibilitem a recuperação energética nas ETEs, bem como prover de infraestrutura os municípios onde inexiste.

O primeiro agrupamento, a partir das informações do banco de dados gerou a divisão dos municípios em quatro grupos, a partir dos quais foram selecionados os municípios para coleta das amostras e análise da caracterização da situação. Porém, após o levantamento detalhado dos dados atualizados de cada município, foi realizado um reagrupamento que resultou na divisão dos municípios do Estado, em três grupos principais, tendo em vista a diferença dos dados anteriores e a realidade atual. Este novo agrupamento, mostrou que existem três grupos de municípios: Grupo 01, composto por municípios predominantemente com mais de 100 mil habitantes e que já possuem soluções coletivas de coleta e tratamento de esgoto para mais de $20 \%$ da população; Grupo 02, constituído por poucos municípios que possuem soluções coletivas a nível municipal ou em loteamentos, e muitos municípios apenas com soluções individuais; e por fim, o Grupo 03, composto majoritariamente por municípios que não possuem solução coletiva e que tem menos de 50 mil de habitantes, com exceção de quatro municípios que contém ETEs em residenciais. A diferença principal entre os municípios que não possuem solução coletiva nos Grupos 02 e 03, se refere ao valor de IDH, que está acima de 0,6 nos municípios do Grupo 02 e abaixo de 0,6 no Grupo 03. Os valores de PIB também devem ter influenciado na segregação, onde o Grupo 02 possui valores mais elevados, para a maioria dos municípios, em relação ao Grupo 03. 
A partir da descrição da situação do esgotamento sanitário e da divisão dos grupos, foi possível aprofundar a análise sobre a recuperação energética a partir do esgoto no Estado do Maranhão. Foram realizadas coletas de amostras e ensaios com esgoto doméstico de diferentes cidades, que no novo agrupamento dos municípios, são representados por dois municípios do Grupo 01 (Codó e São Luís), três municípios do Grupo 02 (Bacabal, Itapecuru Mirim e Miranda do Norte), e três municípios do Grupo 03 (Afonso Cunha, Coroatá e Lagoa Grande do Maranhão). Devido ao número reduzido de municípios no Grupo 01 e sua distância da capital, de forma a facilitar as coletas, repetiu-se a coleta em Codó e São Luís nas Coletas 01 e 02. Para ambas as coletas, contudo, a caracterização das amostras com relação ao teor de Sólidos e análise elementar se mostraram com valores abaixo da média da literatura para todos os grupos, apenas as informações de DBO se aproximaram dos valores da literatura mais atual.

No que se refere aos resultados dos testes empíricos, estes não tiveram resultados expressivos para gerar uma curva de geração de biogás. Observou-se que a carga orgânica das amostras é baixa, indicando um efluente demasiadamente diluído, dificultando a geração de biogás. Este resultado é reforçado inclusive pelo cálculo de potencial teórico, o qual também não apresentou resultados satisfatórios, com exceção dos valores obtidos para o município de Codó. Os motivos atrelados a este baixo desempenho no cálculo teórico e empírico, podem estar relacionados à baixa carga orgânica, e no caso do ensaio, envolvem também aspectos como o reduzido quantitativo de amostra, com apenas $0,4 \mathrm{~L}$, que são pouco representativos em relação a uma planta real, e neste caso, a escala pode ter prejudicado o seu desempenho. Logo, considerando que os resultados de potencial teórico também apresentaram inconsistências, é necessário repetir os experimentos com mais amostras, mais concentradas, e com maiores volumes.

Além disto, é necessário analisar criteriosamente a forma de coleta, armazenamento e transporte, para garantir que não haja variação significativa nas condições da amostra antes das análises, pois a coleta e armazenagem pode ter sido um fator de influêcia nos resultados teóricos e empíricos de potencial de biogás. Na literatura encontrada não são colocadas restrições para o procedimento adotado neste estudo. De qualquer maneira, para próximos estudos seria importante realizar as análises o mais breve possível após a coleta, para que o tempo entre coleta e análise e a armazenagem não influenciem nos resultados.

Com relação aos resultados obtidos por meio dos medidores de vazão de biogás na ETE Vinhais, em São Luís, estes poderiam auxiliar na determinação de geração de biogás, contudo, considerando que dos quatro aparelhos, três apresentaram problemas na aferição durante a medição, seja por problemas de equipamento, calibração ou baixa produção de biogás, 
impossibilitando a detecção, a confiabilidade dos dados obtidos é baixa. De qualquer maneira, os valores obtidos demonstram detecção pouco significativa de biogás, aspecto que pode estar relacionado ao próprio aferidor, bem como às condições do substrato e a captação do biogás na planta, onde pode estar ocorrendo o escape no reator ou na tubulação. É necessária uma manutenção na ETE, de forma a sanar problemas com o escape, e a verificação dos medidores, para garantir que estejam calibrados corretamente. Além dos aspectos acima citados, são necessárias estratégias na forma da gestão do efluente envolvendo forma de coleta, e também tecnologias nas plantas de tratamento, de maneira a possibilitar a recuperação energética, com um efluente com maior carga orgânica.

Com este panorama da recuperação energética a partir de efluentes domésticos no Estado, é possível ter uma base preliminar para uma análise holística com relação à real viabilidade para uso destas tecnologias. As políticas públicas em prol deste tema precisam considerar os aspectos técnicos, econômicos, territoriais, sociais e ambientais, para que tenham sucesso no desenho de ações para o setor. É necessário ainda que seja aprofundado o estudo das principais características advindas destes aspectos acima mencionados, e o seu peso na definição sobre a implementação destas tecnologias nos municípios. A seguir cada grupo de municípios é avaliado com relação às características indicadas pela literatura e pelo presente estudo atravás da metodologia da matriz SWOT.

\subsection{Análise das oportunidades e dificuldades}

Com base nas informações coletadas na revisão de literatura e no estudo de caso, podem ser sugeridos certos parâmetros para avaliação holística da situação de cada grupo ou município, de forma a recomendar tecnologias mais adequadas para cada um. Não foi possível realizar a análise de todos os aspectos, pois dados como tempo de detenção hidráulico, demanda de energia, TIR, VPL, custo de implantação e operação, entre outros, exigem caracterizações e estimativas mais detalhadas, que não foram incorporados nesta dissertação. Abaixo seguem os parâmetros selecionados para auxiliar na elaboração da análise SWOT:

- Análise técnica:

- Características do resíduo - quantidade da carga orgânica (DQO, Sólidos e análise elementar);

○ Características da tecnologia - vazão de entrada; 
- Análise territorial:

- Características geográficas - temperatura ambiente média;

- Características de infraestrutura - condições de coleta e tratamento dos efluentes, condições de disposição do lodo;

- Análise econômica:

- Características econômico financeiras - investimento em saneamento pelo titular, empresa ou Estado;

- Características dos custos com esgotamento sanitário - custos de implantação e operação;

- Característica do uso da energia - condições de uso do biogás, percentual de aproveitamento do biogás na redução de custos da planta;

- Análise social

- Características sobre a aceitação social - confiança na tecnologia e geração de empregos;

- Análise ambiental

- Características sobre impactos ambientais negativos - condições de disposição do lodo e consumo de energia elétrica;

- Características sobre emissão de gases do efeito estufa - condições do uso do biogás;

Conforme descrito na metodologia, a análise de cenário auxilia na identificação das potencialidades e ameaças para se alcançar certo objetivo. Neste caso, foi analisado o cenário de cada grupo com relação ao uso da recuperação energética a partir dos efluentes domésticos. Importante destacar que com base no levantamento feito para o diagnóstico da situação no Maranhão, os municípios foram redistribuídos, conforme Tabela 15, e a análise foi realizada neste novo agrupamento.

Logo, após diagnóstico da atual situação maranhense com relação ao esgotamento sanitário, análise do potencial teórico e empírico da produção de biogás e análise de condicionantes relevantes para a adesão de soluções de recuperação energética a partir do esgoto doméstico, foi realizada a análise das oportunidade e dificuldades, com sugestões das alternativas tecnológicas mais adequadas para cada grupo. Neste estudo, considerou-se as oportunidades, não só os aspectos externos, mas também os aspectos internos (forças), e no caso das dificuldades, considerou também os aspectos externos (ameaças) e internos (fraquezas). 
Importante reforçar que os 217 municípios foram dividos em três Grupos após o levantamento de informações, com base na sua similaridade de características sanitárias e demográficas, conforme Tabela 15. O Grupo 01, conforme mencionado, é composto por municípios predominantemente com mais de 100 mil habitantes e que já possuem soluções coletivas de coleta e tratamento de esgoto para mais de $20 \%$ da população

$\mathrm{Na}$ Tabela 32, a seguir, é analisado o Grupo 01.

Tabela 32 - Análise SWOT do Grupo 01.

\section{Grupo 01}

Forças

Fraquezas

- Características da tecnologia: elevado potencial de vazão de entrada elevado

- Características de geográficas: clima tropical, temperatura média $27^{\circ} \mathrm{C}$

- Características de infraestrutura: ETEs disponíveis para tratamento e disponibilidade de aterro próximo para destinar lodo

- Características econômico financeiras: fontes de financiamento ou disponibilidade de recurso para investimento em esgotamento sanitário

- Características sobre a aceitação social: população tem conhecimento da rede de coleta e das plantas de tratamento, e existe mão de obra capacitada para empregar

- Características do resíduo: baixa carga orgânica

- Características de geográficas: elevado índice pluviométrico, média anual $938 \mathrm{~mm}$ tem afetado concentração do esgoto devido a ligações com drenagem

- Características sobre emissão de gases do efeito estufa: biogás gerados nas ETEs existentes é queimado em flares ou liberado sem queima

- Características sobre impactos ambientais

negativos: possbilidade de dispor lodo em aterros existentes

\begin{tabular}{|c|c|}
\hline Oportunidades & Ameaças \\
\hline $\begin{array}{c}\text { - Características dos custos com esgotamento } \\
\text { sanitário: investimento apenas para adaptar ETE } \\
\text { para recuperação energética, com a } \\
\text { possibilidade de investimento em novas } \\
\text { tecnologias, e para ampliação da coleta } \\
\text { - Característica do uso da energia: uso do biogás } \\
\text { ou lodo poderia reduzir custo de energia elétrica } \\
\text { da ETE }\end{array}$ & $\begin{array}{c}\text { • Características do resíduo: possível } \\
\text { diluição do efluente com ligações } \\
\text { clandestinas com rede de drenagem pluvial } \\
\text { - Características dos custos com esgotamento } \\
\text { sanitário: ausência de predisposição das } \\
\text { instituições para investir } \\
\text { • Característica do uso da energia: falhas } \\
\text { técnicas na geração e utilização do biogás } \\
\text { • Características de infraestrutura: } \\
\text { necessidade de diversas manutenções } \\
\text { corretivas e não ligação da população à rede } \\
\text { de esgoto }\end{array}$ \\
\hline
\end{tabular}

Fonte: Elaborado pela própria autora.

No Grupo 01, observa-se que existem diversas aspectos oportunos que podem compensar as fraquezas e ameaças presentes nestes municípios. Dentre as principais 
oportunidades está a existência de infraestrutura de coleta e tratamento de esgoto no município, destinação de recursos financeiros para ampliação do sistema, economia de escala proporcionada pelo volume de esgoto gerado, possibilidade de investimento em tecnologias para concentração do esgoto e conhecimento técnico disponível. Com relação aos parâmetros, a carga orgânica e a vazão de entrada estão relacionados também ao tamanho da população, densidade demográfica, e condições climáticas, e influenciam na definição da tecnologia e do porte da ETE (SANEPAR, 2017). No caso do Grupo 01, as tecnologias são beneficiadas principalmente pelo volume de efluentes gerados, e seu impacto poluidor. Além disto, dos seis municípios desse Grupo, quatro possuem PMSB aprovado. O município de Imperatriz está com o PMSB em andamento.

Tecnologias que podem ser utilizadas são reatores UASB e biorreatores de membrana, ou a combinação de tecnologias. Neste caso podem ser construídas plantas de médio e grande porte, tendo em vista que o volume de efluente é determinado pelo tamanho da população e a densidade demográfica. Contudo, o uso das tecnologias deve se adequar às características do substrato, onde preferencialmente ocorra sua concentração antes do tratamento, para que haja maior produção de biogás e consequentemente, aproveitamento energético e redução de custos. Este aspecto pode ser otimizado com a correção de ligações clandestinas de rede pluvial na rede de esgotamento, por exemplo. Importante ressaltar também, a necessidade de capital para investimento na ampliação da rede coletora, assim como, ações de conexão da população à rede coletora, para viabilizar a economia de escala da geração de biogás.

Desta forma, nas plantas já existentes que utilizam reatores, devem ser analisadas possibilidades de concentrar o esgoto, além de melhorias ou aquisição de materiais resistentes à corrosão do reator e da tubulação de gás, ocasionado devido ao biogás. Em plantas que utilizam lagoas de estabilização, deve ser analisada a possibilidade de secagem e incineração do lodo, ou mesmo adotar tecnologias de digestão do logo para geração de biogás (DE QUEIROZ; PAES; FERNANDES, 2018). O uso do biogás nestes casos pode ser para secagem do lodo, de forma a reduzir o volume e peso a ser descartado, ou manejado (ROSA et al., 2016)

A seguir é analisado o Grupo 02, constituído por poucos municípios que possuem soluções coletivas a nível municipal ou em loteamentos, e muitos municípios apenas com soluções individuais, conforme Tabela 33. 
Tabela 33 - Análise SWOT do Grupo 02.

\begin{tabular}{|c|c|}
\hline \multicolumn{2}{|c|}{ Grupo 02} \\
\hline Forças & Fraquezas \\
\hline $\begin{array}{c}\text { - Características de geográficas: clima } \\
\text { tropical, temperatura média } 27^{\circ} \mathrm{C} \\
\text { - Características de infraestrutura: ETEs } \\
\text { disponíveis para tratamento (municipais e em } \\
\text { residenciais) } \\
\text { - Características sobre a aceitação social: } \\
\text { população tem conhecimento da rede coletora } \\
\text { e das plantas de tratamento em alguns } \\
\text { municípios }\end{array}$ & $\begin{array}{c}\text { - Características da tecnologia: baixa carga } \\
\text { orgânica e baixa vazão afluente; } \\
\text { - Características de infraestrutura: } \\
\text { indisponibilidade de aterro próximo para } \\
\text { destinar lodo; } \\
\text { - Características sobre emissão de gases do } \\
\text { efeito estufa: biogás gerados nas ETEs } \\
\text { existentes é queimado em flares ou liberado } \\
\text { sem queima } \\
\text { - Características econômico financeiras: } \\
\text { baixa disponibilidade de recursos e fontes } \\
\text { de financiamento para investimento } \\
\text { - Características sobre a aceitação social: } \\
\text { disponibilidade de mão de obra capacitada } \\
\text { é restrita }\end{array}$ \\
\hline Oportunidades & Ameaças \\
\hline $\begin{array}{c}\text { - Características dos custos com esgotamento } \\
\text { sanitário: investimento apenas para adaptar } \\
\text { ETE para recuperação energética em ETE } \\
\text { existente } \\
\text { - Característica do uso da energia: uso do } \\
\text { biogás ou lodo poderia reduzir custo de } \\
\text { energia elétrica da ETE }\end{array}$ & $\begin{array}{c}\text { • Características dos custos com } \\
\text { esgotamento sanitário: baixo interesse em } \\
\text { investimento para implementar novas ETEs } \\
\text { e coleta } \\
\text { - Característica do uso da energia: falhas } \\
\text { técnicas na geração e utilização do biogás } \\
\text { nas ETEs existentes e novas }\end{array}$ \\
\hline
\end{tabular}

Fonte: Elaborado pela própria autora.

No Grupo 02, observa-se que ainda existem diversos aspectos oportunos em comparação às dificuldades. Percebe-se a existência de ETEs municipais de pequeno porte e ETEs localizadas em residenciais utilizando tecnologia de reator UASB ou lagoas facultativas em certos municípios. Desta forma, tem-se o potencial de utilizar as soluções já existentes para aproveitamento energético. $\mathrm{O}$ volume de esgoto gerado nestes municípios pode ser suficiente para a recuperação energética, tendo em vista que mais da metade possui acima de 20 mil habitantes, o que pode permitir uma economia de escala a depender da tecnologia utilizada. Contudo, sabendo que são municípios com menor número de população e densidade demográfica em relação ao Grupo 01, existe maior dificuldade na captação de recursos para investimento na infraestrutura de coleta e tratamento. Nos municípios deste Grupo 02, é possível recomendar que a tecnologia utilizada seja de reatores UASB, de preferência, e em segunda opção, lagoas facultativas com utilização do lodo para recuperação energética por digestão ou por compostagem, para a produção de fertilizantes. Lembrando que, no caso do uso 
do lodo, é necessário garantir que suas características estejam de acordo com a Resolução CONAMA No 430/2011.

As dificuldades mais significativas deste grupo envolvem os investimentos na infraestrutura de coleta e nas plantas de tratamento, onde a escolha do tipo de tratamento dependerá da análise de cada tecnologia para os aspectos mencionados e sua posterior comparação. Além disto, dos 65 municípios desse Grupo, 12 possuem PMSB aprovado.

Por fim, o Grupo 03, composto majoritariamente por municípios que não possuem solução coletiva e que tem menos de 50 mil de habitantes, com exceção de quatro municípios que contém ETEs em residenciais, tem sua análise na Tabela 34.

Tabela 34 - Análise SWOT do Grupo 03.

\begin{tabular}{|c|c|}
\hline \multicolumn{2}{|c|}{ Grupo 3} \\
\hline Forças & Fraquezas \\
\hline $\begin{array}{l}\text { - Características de geográficas: clima } \\
\text { tropical, temperatura média } 27^{\circ} \mathrm{C}\end{array}$ & $\begin{array}{c}\text { - Características de infraestrutura: não possui } \\
\text { coleta e ETEs disponíveis para tratamento - } \\
\text { raras exceções em residenciais } \\
\text { - Características da tecnologia: baixa carga } \\
\text { orgânica e baixa vazão afluente; } \\
\text { - Características econômico financeiras: } \\
\text { indisponibilidade de fontes de financiamento } \\
\text { ou recurso para investimento em } \\
\text { esgotamento sanitário; } \\
\text { • Características sobre a aceitação social: } \\
\text { população não tem conhecimento na área e } \\
\text { dificuldade de mão de obra capacitada } \\
\text { - Características sobre impactos ambientais } \\
\text { negativos: impossibilidade de dispor lodo em } \\
\text { aterros existentes pela distância; }\end{array}$ \\
\hline Oportunidades & Ameaças \\
\hline $\begin{array}{c}\text { - Característica do uso da energia: uso do } \\
\text { biogás poderia reduzir custo de energia } \\
\text { elétrica da ETE } \\
\text { - Característica da tecnologia: possível } \\
\text { integração dos resíduos sólidos orgânicos e } \\
\text { lodo para codigestão; ou uso de } \\
\text { biodigestores compactos }\end{array}$ & $\begin{array}{l}\text { - Características dos custos com esgotamento } \\
\text { sanitário: não interesse das instituições para } \\
\text { investir na implementação de coleta e novas } \\
\text { ETEs }\end{array}$ \\
\hline
\end{tabular}

Fonte: Elaborado pela própria autora.

Com relação ao Grupo 03, este é constituído por pequenos municípios com pouca u nenhuma infraestrutura e recursos para esgotamento sanitário, onde predominam o uso de soluções individuais incluindo fossas sépticas, valas, entre outros. Com raras exceções existem 
municípios que possuem ETE em algum residencial. Neste caso, existe um elevado custo de investimento para construir toda a infraestrutura de coleta e tratamento, e com a possibilidade de ser um investimento com um payback elevado pois, parte significativa da população dos municípios está incluída em programas de tarifa social ou com isenção de tarifa pela baixa renda per capita. Desta forma, recomenda-se o uso da codigestão do lodo, em reatores, em conjunto com os resíduos sólidos orgânicos do município, alternativa que pode contribuir para a melhor disposição destes dois tipos de resíduos que possuem manejo precário. Esta solução pode ocorrer inclusive com o consórcio entre municípios. Além disto, dos municípios 146 desse Grupo, apenas sete possuem PMSB aprovado.

Existe ainda a possibilidade do uso de biodigestores familiares, contudo, estes podem enfrentar problemas de aceitação social na implementação e uso, devido ao desconhecimento da população sobre a tecnologia, na falta de um trabalho sócio ambiental acerca do tema. Para este Grupo recomenda-se também o uso de lagoas de tratamento com o uso posterior do lodo para a produção de fertilizante. Assim como no Grupo 02, as principais dificuldades envolvem os investimentos na infraestrutura de coleta e nas plantas de tratamento, e a definição da tecnologia de tratamento dependerá da análise de cada tecnologia para os aspectos mencionados e sua posterior comparação.

Tanto o Grupo 02 quanto o Grupo 03 predominam as soluções individuais, como fossas. Desta forma, é importante se considerar também projetos a curto prazo que possam auxiliar no melhor tratamento destes efluentes e possivelmente, até ajudar a viabilizar seu tratamento coletivo. Atualmente, existem estudos de utilização de caminhões fossa para coleta dos efluentes, como forma de manutenção da fossa, que podem transportar este resíduo e concentrálo em ETEs, e utilizar do seu lodo para co-digestão junto a resíduos sólidos orgânicos. No curto prazo esta iniciativa reduziria custos, devido não ser necessário o investimento em redes coletoras em todo o município, principalmente em pequenos municípios.

Em resumo, através das matrizes SWOT é possível compreender a complexidade da análise da situação de cada grupo. Observa-se, principalmente, que o Grupo 01, composto por municípios de maior porte e com elevado percentual de atendimento do serviço em relação ao restante dos municípios do Estado, tem mais facilidade para a instalação de tecnologias de recuperação energética do que o Grupos 02 e 03 que possuem pouca ou nenhuma infraestrutura de coleta e tratamento no município, com exceções. No Grupo 02, predominam municípios de médio porte com casos de atendimento por solução coletiva, mas solução individual predomina. No Grupo 03, com 146 municípios, predominam municípios de pequeno porte apenas com 
soluções individuais. Estes aspectos ficam bem demarcados nos cenários representados na SWOT de cada Grupo, onde o Grupo 03 apresenta fraquezas e ameaças mais desafiadoras do que forças e oportunidades.

Depreende-se então que a viabilidade da recuperação energética através do biogás no Estado pode ocorrer a depender de melhorias nas plantas já existentes, principalmente nos municípios do Grupo 01. As melhorias envolvem modificações na característica do substrato, adaptações na infraestrutura de coleta, com a correção de irregularidades e incentivo da população a conectar-se à rede coletora, e melhorias nas ETEs existentes para que não ocorra escape dos gases. Os Grupos 02 e 03, já apresentam outras dificuldades, que podem inviabilizar a recuperação de biogás, como inexistência de infraestrutura e baixo volume de esgoto gerado em pequenos municípios, com baixa carga orgânica. Ou seja, conforme a hipótese, a recuperação de energia através do biogás de efluentes domésticos nos municípios do Maranhão utilizando as tecnologias existentes é possível, contudo a viabilidade do uso da tecnologia varia de acordo com as características do município e com as condições do substrato e das plantas de tratamento.

Certos municípios do Grupos 01 e 02 possuem infraestrutura de solução coletiva municipal, enquanto, as soluções coletivas existentes no Grupo 03 são concentradas em loteamentos. De qualquer forma, a existência de rede coletora em uma parcela do município reduz os custos de implantação do sistema de esgotamento sanitário. A depender do município, nos locais onde há reatores, é possível realizar adaptações para a recuperação energética através do biogás. Já em locais com lagoas, é possível realizar a codigestão do lodo com resíduos sólidos orgânicos ou o uso do lodo como fertilizante. Nos municípios com as características do Grupo 02 e 03, que não apresentam nenhuma infraestrutura, a codigestão é um investimento mais expressivo, mas que pode apresentar menor payback em relação ao uso de fertilizantes. São necessárias análises mais aprofundadas para realizar esta comparação. Desta forma, se confirma a segunda hipótese, com relação ao uso do lodo e da codigestão como solução para municípios que não tem condições de realizar a recuperação energética através do biogás apenas a partir do efluente, contudo exige análises mais detalhadas, mas segue como uma alternativa.

Observa-se então que, a definição das tecnologias por grupo, baseada na análise SWOT, identificou como pontos de forças e oportunidades, as caraterísticas demográficas quando apresentam elevado tamanho da população e densidade demográfica, infraestrutura já existente, e a disponibilidade de recursos para investimento devido aos aportes já realizados, fato que pode ser confirmado no Grupo 01. Neste caso, a hipótese se comprova, tendo em vista que as ETEs já existentes estão majoritariamente localizadas nos municípios com maior população e 
maior investimento em saneamento, que não está diretamente relacionado ao PIB per capita do município. Desta forma, nesta primeira análise, o PIB per capita não representa um indicador que interfira diretamente nos investimentos ou infraestrutura de saneamento já existente, no caso do Maranhão.

Além disto, são necessárias análises de correlação e levantamento de mais variáveis para consolidar esta afirmação. No Maranhão existem diversos municípios na Situação Institucional Básica, conforme classificado no Atlas do Esgoto (ANA, 2017), representados por estes municípios de pequeno porte, principalmente abaixo de 20 mil habitantes, sem infraestrutura de esgotamento sanitário, presentes nos Grupos 02 e 03, deste trabalho. Os quais representam também a maior demanda de investimento.

\subsection{Análise de alternativas}

No Estado do Maranhão, percebeu-se que as ETEs existentes precisam de adaptações para conseguir utilizar a recuperação energética. Dificuldades não envolvem apenas a infraestrutura da ETE, mas também a infraestrutura de coleta, para evitar a entrada de água pluvial, e no caso de São Luís, água salobra. De qualquer maneira, tendo em vista a estrutura já construída na maior parte das ETEs, o custo de implementação de tecnologias de recuperação energética torna o projeto mais viável economicamente, a depender da ETE. No caso de novas plantas, existe uma possibilidade de construção de ETEs em novos loteamentos, principalmente, nos sistemas compactos, que podem chegar em média até $20 \mathrm{~L} / \mathrm{s}$, como existem em alguns municípios de todos os grupos. São sistemas menores que não precisam executar obras em áreas já urbanizadas e conseguem ter um maior controle do sistema, e consequentemente, possivelmente melhor concentração do efluente.

Com relação à melhoria das carasterísticas do substrato, uma alternativa seria concentrar $o$ esgoto, desde a fonte, utilizando menos água para sua coleta e garantindo a ausência de águas pluviais na rede, e também com a implantação de uma tecnologia de concentração do efluente, como Osmose Reversa ou Biorreatores de Membrana. Outra alternativa seria acrescentar resíduos sólidos orgânicos para realizar a codigestão. Neste caso, a codigestão pode ser de mais fácial implementação em municípios com até 50 mil habitantes que ainda não possuem nenhuma infraestrutura coletiva para esgoto e possui soluções precárias para o resíduo orgânico. Esta última solução implica a necessidade de um tanque de mistura para homogeneizar o lodo do esgoto com os resíduos orgânicos segregados na fonte, no município, entre outras adaptações. Existem projetos com o intuito de trabalhar o uso de caminhões limpa fossa para 
manutenção frequente das fossas sépticas em municípios que utilizam este tipo de solução individual. Desta forma, estes caminhões poderiam transportar este resíduo até seu tratamento em uma ETE, possibilitanto o acúmulo da matéria orgânica para geração de biogás, sem a necessidade de elevados investimentos na construção de redes coletoras nos municípios, no curto prazo.

Com relação à solução mais promissora para o aproveitamento energético do esgoto doméstico, observa-se a utilização dos reatores UASB, com aproveitamento elétrico ou térmico, podendo ser utilizada a cogeração para melhor rendimento energético. Estudo de Scheuer (2019) aponta que para o investimento necessário para este tipo de projeto, o retorno compensa para municípios com mais de 100 mil habitantes. Porém, é preciso considerar as variáveis previamente mencionadas, técnicas, territoriais, sociais, econômicas e ambientais.

Com este panorama sobre a situação do Estado e as recomendações de tecnologias a serem utilizadas, é possível pensar estratégias e apronfundar os estudos para expansão e melhoria da infraestrutura de esgotamento sanitário com recuperação energética, considerando principalmente a viabilidade técnica e econômica, no que se refere à produção de energia e a redução no custo de implantação e operação destas tecnologias. Estas análises devem ser seguidas da avaliação territorial, social e ambiental, para garantir a melhor localização das plantas, os recursos a serem utilizados, os impactos na população e meio ambiente, entre outros aspectos.

Com vistas às informações apresentadas e à aprovação do novo Marco do Saneamento Básico, fica explícita a dificuldade apresentada para o país avançar no aumento dos índices de cobertura sem a mudança nos modelos prévios de concessão dos serviços, sem investimentos públicos ou privados, e sem o uso do subsídio cruzado entre municípios (CANCELLI, 2013). Os pequenos municípios que não possuem ganhos de escala são os que apresentam mais dificuldades para aumentar os índices de saneamento, conforme apresentado no Grupo 02 e 03, e as discussões do novo marco não garantem que esta situação seja melhorada, a não ser que a definição das unidades regionais de saneamento básico ou blocos de referência seja feita de forma estruturada, aspecto que é questionado por aqueles que veem fragilidades na nova Lei. De qualquer maneira, o incentivo de agregar soluções de recuperação energética se mostra como propulsor do setor, assim como gera benefícios e avanços para o desenvolvimento de soluções para a geração de energia renovável no país. Sendo assim, a sinergia da solução deve ser estudada com mais detalhes, a começar pelas conclusões e recomendações da pesquisa. 


\subsection{Análise dos desafios}

Existem diversos aspectos que servem de barreira ou dificultam o avanço do devolvimento de ações em favor da recuperação energética de efluentes. Por exemplo, o cenário regulatório de outros Estados demonstra que a pressão da legislação auxilia no desenvolvimento de políticas públicas e implantação de ações em prol da disposição adequada e aproveitamento de resíduos no Estado, como ocorre na região Sul do país, como no estudo Cornelli \& Alegre (2014). Atualmente, as principais legislações a nível estadual se referem principalmente a regulamentar a emissão de efluentes em recursos hídricos, de forma a mitigar pontos de poluição. Contudo, são necessárias regulamentações a nível estadual voltadas, não só à proibição da destinação incorreta, impedindo o lançamento destes efluente em corpos hídricos, mas também incentivos para criar soluções e fomentar a produção e consumo de biogás e de biometano, como a Lei № 19.500 de 21/05/2018 do Estado do Paraná.

Além distos, ao longo do desenvolvimento do estudo foi possível extrair a realidade distinta encontrada no Maranhão em relação a outros Estados como São Paulo e Paraná. Nestes outras Estados, estas tecnologias de recuperação energética a partir do biogás, apesar de ainda pouco numerosas encontram-se melhor consolidadas e as dificuldades enfrentadas para sua utilização, principalmente no que se refere a disponibilidade de infraestrutura e conhecimento sobre o tema, demonstra que existem ainda diversos desafios no Estado do Maranhão quanto a esta temática.

Adicionalmente, destaca-se a qualidade dos dados públicos disponíveis, os quais, em muitas localidades, divergem significativamente da realidade. Aspecto que deve ser menos agravante em Estados da Região Sudeste e Sul, as quais possuem maior histórico e condições que obter informações mais confiáveis. Este aspecto é especialmente preocupante, pois é a partir destes dados oficiais do SNIS e ANA que são tomadas decisões e pensadas políticas públicas. Desta forma, questiona-se como tem sido coletadas estas informações e da necessidade de ser realizado um plano de auditoria sobre elas. Seria ideal realizar um estudo transversal com a validação por amostragem em todos Estados, para verificar a aderência das informações à realidade de cada Estado e quais são as melhores práticas. Principalmente verficiar se realmente metade da população brasileiro não possui nenhuma solução de de esgotamento sanitário, ou se trata de nenhuma solução coletiva. A falta de dados disponíveis de forma confiável, é fator crítico para melhorar o setor e se trata de uns dos principais aspectos a serem enfatizados, caso contrário não será possível medir a evolução do histórico do setor ao longo do tempo de forma fidedigna, impactanto em tomadas de decisões, tornando-as ineficientes. 
Considerando ainda os resultados obtidos no potencial teórico e empírico, é importante mencionar que a geração de energia a partir dos efluentes não é um fator único para auxiliar na viabilidade das plantas de tratamento. É necessário também que sejam pensadas iniciativas em prol de regulamentar o setor, incentivando mais a expansão da coleta e tratamento do esgoto doméstico e uso dos seus subprodutos, e também políticas que visem a responsabilização e pagamentos por irregularidades causada por despejos irregulares, dentre outras situações.

Além da regulação do setor, estudos e projetos tem sido desenvolvidos para detalhar cada vez melhor o processo de aproveitamento energético dos efluentes, de maneira a auxiliar na melhoria de sua eficiência, como no estudo de Shirado (2014). As análises englobam, principalmente o teor de metano que pode ser aproveitado do biogás gerado e demais condicionantes da operação do sistema completo a nível técnico (POSSETTI et al., 2013). Projetos como o PROBIOGÁS, fruto da parceria com instituição alemã, por meio da Deutsche Gesellschaft für Internationale Zusammenarbeit (GIZ) $\mathrm{GmbH}$, permitiu trabalhos para maior desenvolvimento do setor e, consequente desenvolvimento rumo às metas PLANSAB, assim como contribuindo também para a geração distribuída de energia e a maior diversificação da matriz energética (BRASIL. MINISTÉRIO DAS CIDADES., 2015; SANEPAR, 2016).

\section{Conclusão e recomendações}

Com o compromisso de "alcançar o acesso a saneamento e higiene adequados e equitativos para todos" até 2033, conforme o Plano Nacional de Saneamento (PLANSAB) (MINISTÉRIO DAS CIDADES, 2013), e com baixos índices de cobertura de esgotamento sanitário, o Brasil tem buscado soluções para mudar o cenário atual. Para além do PLANSAB, a Agenda mundial de 2030 também estimula que as políticas que envolvam os ODS 6-Água potável e saneamento e ODS 7 - Energia acessível e limpa, sejam alcançadas. Desta forma, o uso da recuperação energética de resíduos tem servido como incentivo para o setor de saneamento, principalmente com resíduos sólidos, atualmente. Contudo ainda apresenta um potencial significativo para ser utilizado, que pode se converter na redução de custos de operação das plantas e, em alguns casos, gerando excedente energético, por exemplo.

Nesta pesquisa, o uso do Método Misto permitiu a compilação de diversas informações, as quais possibilitam uma análise integrada, fornecendo subsídio a outros estudos e, principalmente, à tomada de decisões em prol da melhoria do sistema de esgotamento sanitário com aproveitamento energético no Estado do Maranhão. No estudo, os dados coletados pela revisão de literatura, estudo de caso, coleta e análise de amostras, foram organizados e avaliados 
com os parâmetros que influenciam a implementação das plantas de tratamento e recuperação energética no Maranhão, de forma a sugerir a tecnologia mais adequada para cada grupo de municípios, a partir de uma análise de cenário para cada um. A segmentação dos munícipios em grupos serviu para facilitar a análise de todo o Estado, e permitiu avaliar a influência de certos aspectos, como por exemplo, as características do substrato, na adoção de tecnologias de recuperação energética a partir de efluentes domésticos. As visitas às cidades demonstram as desigualdades entre as políticas de saneamento em cada uma delas, no que se refere à coleta e tratamento de esgoto. Importante destacar também, que após o diagnóstico sobre a situação do esgotamento sanitário dos municípios percebeu-se que o percentual de cobertura por solução individual, com a utilização de fossas e sumidouros, é expressivo no Estado, do contrário que expressam os dados oficiais, os quais demonstram que precisam ser atualizados. Este aspecto, inclusive, deve ser considerado com relação aos dados nacionais, onde pode estar ocorrendo problemas como no Maranhão, incorrendo na divulgação e tomada de decisão baseada em informações inconsistentes.

Com relação às hipóteses da pesquisa, os ensaios não possibilitaram a confirmação sobre a possibilidade da recuperação energética através do biogás, porém o potencial teórico indica que este seja possível, principalmente em municípios como do Grupo 01, mediante a concentração maior de sólidos e carbono no efluente. Este Grupo apresenta mais oportunidades para o uso da recuperação energética pelas plantas já existentes, motivado por fatores como a economia de escala que é obtida pelo contingente populacional e densidade demográfica elevada, assim como, pela disponibilidade recursos para investir em melhorias nas plantas e na rede coletora. No caso dos Grupos 02 e 03, também não foi possível comprovar a possibilidade de geração de biogás de forma significativa em plantas existentes, contudo, este cenário pode se alterar em loteamentos, ou nas ETEs municipais de pequeno porte, mediante maior concentração do efluente, como em Codó, conforme mencionam diversos artigos sobre o aumento da carga orgânica ter impacto significativo na performance das ETEs e principalmente na geração de biogás. Já aqueles municípios onde inexiste infraestrutura de coleta e de tratamento de esgoto, seja na sede do município ou em loteamentos, a recuperação energética através do biogás pode ser estudada para verificar a viabilidade por meio da codigestão com resíduos sólidos orgânicos do município, ou com alternativas que envolvam utilizar o lodo como fertilizante. Lembrando que a discussão do trabalho não trata sobre a área rural. Dentre as soluções indicadas para os grupos se recomenda o uso de reatores para municípios como do Grupo 01, e em loteamentos de municípios do Grupo 02 e 03, e no caso destes últimos grupos, sugere-se estudos sobre o uso da codigestão, ou a composição de consórcios para gerenciamento destes resíduos. 
Com relação ao potencial de geração de biogás, a partir dos ensaios foi possível notar que as características do substrato são fundamentais para viabilizar a recuperação energética através do biogás, onde observou-se que não houve geração de biogás em face da baixa concentração e possivelmente devido à baix quantidade de efluente das amostras. Desta forma, é necessário um maior volume de efluente para gerar uma economia de escala, assim como, para adequar a concentração do efluente e, consequente geração de biogás, são necessários investimentos na rede coletora e/ou na ETE. Logo, conforme apontado na hipótese, a vazão afluente na ETE, que está diretamente relacionada ao tamanho da população e densidade populacional, a quantidade de investimentos para o setor, e as características dos substratos influenciam diretamente a viabilidade da recuperação energética através do biogás em cidades do Estado do Maranhão. Contudo, estes não são os únicos aspectos, de forma que mais estudos são necessários para compor as variáveis e definir o peso de cada uma.

Considerando o levantamento e os cálculos de potencial, é possível afirmar que, atualmente, aproximadamente, seis municípios tem condições de utilizar a recuperação energética através do biogás, a partir de efluentes domésticos no Estado, mediante investimentos em concentração do efluente e melhorias nas ETEs já existentes, pois pertencem ao Grupo 01, e apresentam maior potencial de geração de biogás, com exceção de Alto do Parnaíba, por ter população abaixo de 15 mil habitantes. No Grupo 01, o município de Codó se destacou com o maior potencial teórico de geração de biogás, possivelmente devido a maior concentração de carbono, atingindo uma estimativa de $16.828 \mathrm{Nm}^{3} / \mathrm{d}$, em uma ETE municipal, abaixo da produção da capital São Luís, possivelmente, devido à diluição do substrato. Nas ETEs em 12 municípios no Estado, municipais ou residenciais, que utilizam reatores, lagoas e lodos ativados, podem aproveitar o biogás produzido nos reatores e o lodo das lagoas e lodos ativados, através de codigestão, para recuperação energética. Estes municípios fazem parte do Grupo 02 e 03 e demandam uma avaliação em cada caso, para a tomada de decisão. Por fỉm, 197 municípios não possuem qualquer infraestrutura coletiva para coleta e tratamento de esgoto doméstico.

Importante destacar que todas as soluções, para todos os grupos, prescindem de investimento na implantação ou ampliação da infraestrutura de rede coletora de esgoto e nas tecnologias de tratamento de esgoto. Nestes casos, uma das alternativas passa pela captação de recursos para investimento e estudos quanto a viabilidade de uso destas soluções por meio da consolidação de consórcios entre municípios próximos. Além disto, é possível pensar em projetos que utilizem caminhões fossa no curto prazo, enquanto não é construída a rede de coleta no município, tendo em vista a predominância desta solução no Estado. 
Tendo em vistas as características do efluente doméstico no Maranhão, o uso dos biorreatores de membrana seria a tecnologia ideal devido à possibilidade de filtração e consequentemente concentração do efluente para posterior tratamento e recuperação energética. Contudo, como a economia de escala não favorece neste caso, os custos devem ser elevados. Desta forma, devem ser pensadas soluções prévias no processo de coleta do esgoto para melhorar as características do substrato favorecendo a geração de energia. A seguir é apresentada a Tabela 35 com o resumo do que se foi levantado e analisado com o estudo.

Tabela 35. Resumo de informações obtidas no estudo.

\begin{tabular}{|c|c|c|}
\hline $\begin{array}{c}\text { Objetivo de } \\
\text { Pesquisa } \\
\end{array}$ & Informações & Resumo dos Resultados \\
\hline $\begin{array}{l}\text { Revisão de } \\
\text { literatura }\end{array}$ & $\begin{array}{l}\text { - Situação do esgotamento } \\
\text { sanitário e uso energético } \\
\text { - Detalhamento das } \\
\text { tecnologias existentes } \\
\text { disponíveis } \\
\text { - Aspectos da viabilidade } \\
\text { do uso das tecnologias de } \\
\text { recuperação energética } \\
\text { de resíduos }\end{array}$ & $\begin{array}{l}\text { - Déficit de esgotamento sanitário e da dsiponibilidade de dados; } \\
\text { - As } 15 \text { ETEs brasileiras com de recuperação de efluentes estão, } \\
\text { principalmente, nas regiões Sul e Sudeste; } \\
\text { - Regulamentação do setor ainda é incipiente; } \\
\text { - Existem diversas soluções para recuperação energética de } \\
\text { - } \text { Ofluentes domésticos; } \\
\text { - } \text { para efluentes mais concentrados em carbono; } \\
\text { - Co-digestão e compostagem são alternativas para } \\
\text { - } \text { aproveitamento energético em municípios pequenos; } \\
\text { econômicos, territoriade do projeto depende de aspectos técnicos, } \\
\text { ecociais e ambientais; }\end{array}$ \\
\hline $\begin{array}{l}\text { Metodologia } \\
\text { do estudo de } \\
\text { caso }\end{array}$ & $\begin{array}{l}\text { Levantamento da } \\
\text { situação atual do } \\
\text { esgotamento sanitário no } \\
\text { Maranhão } \\
\text { - Principais atores } \\
\text { envolvidos no tema } \\
\text { - Divisão de grupos }\end{array}$ & $\begin{array}{l}\text { - Atores do setor: Prefeitura Municipal, CAEMA, SAAE, BRK, } \\
\text { Águas de Timon, CAESI e CODEVASF; } \\
\text { - Responsáveis por: Abastecimento de água: 61\% CAEMA/ } \\
\text { Esgotamento Sanitário: 84\% Prefeituras; } \\
\text { - Agências Reguladoras: MOB, AGERT e CISAB; } \\
\text { - Divisão dos } 217 \text { municípios em } 03 \text { grupos por similaridade } \\
\text { demográfica e sanitária; } \\
\text { - Existem } 68 \text { ETEs no Estado do Maranhão de pequeno, médio e } \\
\text { grande porte, em } 20 \text { municípios, predominam } 49 \text { com reatores; }\end{array}$ \\
\hline $\begin{array}{c}\text { Metodologia } \\
\text { de coleta e } \\
\text { análise das } \\
\text { amostras }\end{array}$ & $\begin{array}{l}\text { - Análise do potencial } \\
\text { teórico e empírico de } \\
\text { biogás e comparação }\end{array}$ & $\begin{array}{l}\text { - Baixa concentração de Sólidos e carbono nos efluentes } \\
\text { coletados na Coleta } 01 \text { e } 02 \text {; } \\
\text { Potencial teórico: Codó apresenta valores de biogás mais } \\
\text { elevados - povavelmente pela maior quantidade de Carbono; } \\
\text { Potencial empírico dos ensaios não apresentou resultado } \\
\text { significativo - possível baixo nível de detecção, baixo volume } \\
\text { de amostra ou condições de coleta; } \\
\text { - Aferição de pressão com resultados não confiáveis devido à } \\
\text { elevada variação e erros nos equipamentos; }\end{array}$ \\
\hline
\end{tabular}




\begin{tabular}{|c|c|c|}
\hline $\begin{array}{c}\text { Objetivo de } \\
\text { Pesquisa }\end{array}$ & Informações & Resumo dos Resultados \\
\hline $\begin{array}{l}\text { Metodologia } \\
\text { de análise de } \\
\text { resultados }\end{array}$ & $\begin{array}{l}\text { - Compilação das } \\
\text { informações coletadas e } \\
\text { análise das diversas } \\
\text { variáveis para aplicação } \\
\text { de recuperação } \\
\text { energética de efluentes } \\
\text { domésticos no Maranhão }\end{array}$ & $\begin{array}{l}\text { Definição de características técnicas, territoriais, econômicas, } \\
\text { sociais e ambientais; } \\
\text { Análise SWOT de cada grupo a partir destas características } \\
\text { aponta o nível de dificuldade de viabilizar a solução; } \\
\text { Grupo 01: mais de } 100 \text { mil habitantes, com soluções coletivas } \\
\text { para mais de } 20 \% \text { da população - Reatores ou Biorreatores de } \\
\text { Membrana; } \\
\text { Grupo 02: predominam soluções individuais, mas possui } \\
\text { soluções coletivas (municipal ou loteamentos) - Reatores, } \\
\text { lagoas, codigestão, compostagem; } \\
\text { Grupo 03: menos de } 50 \text { mil de habitantes, com exceção de } 4 \\
\text { municípios com ETEs em loteamentos - biodigestor familiar, } \\
\text { codigestão, compostagem, caminhão fossa; } \\
\text { Todos municípios necessitam de investimento em rede coletora } \\
\text { e melhoria ou construção de ETE. }\end{array}$ \\
\hline
\end{tabular}

Fonte: Elaborado pela própria autora.

Por fim, conforme o novo Marco Regulatório de Saneamento, a formação de unidades regionais ou blocos de referência, implica a necessidade de mesclar municípios dos três Grupos, de forma a viabilizar a sustentabilidade técnico econômico financeira dos sistemas. Desta forma, como demonstrado na pesquisa os municípios do Grupo 02 e 03 que apresentam mais dificuldades na implantação de soluções de esgotamento sanitário, teriam mais chances de viabilizar o uso destas alternativas. No Maranhão, no que se refere ao esgotamento sanitário, existe uma pequena participação das empresas privadas no setor $(0,9 \%)$, mas que apresentam percentual crescente de atendimento da população, fato que pode indicar os benefícios da entrada da iniciativa privada no setor através de Parceirias Público Privadas (PPP) com as Companhias Estaduais. De qualquer maneira, as discussões acerca da nova regulamentação ainda trarão diversas oportunidades e desafios para o setor, tornando o mais propenso para pensar soluções que estejam atrelados aos Objetivos do Desenvolvimento Sustentável (ODS), garantindo maior sustentabilidade nos processos, e certamente incentivando soluções como o uso da recuperação energética a partir de efluentes domésticos como um dos propulsores do tema.

\subsection{Recomendações}

A seguir, a pesquisa sugere estudos futuros para aprofundar aspectos que não foram possíveis abordar em maior detalhe. 
- Estimativas de geração de biogás deveriam ser realizadas a nível municipal

Em países como o Brasil, onde existem grandes diferenças na gestão de resíduos sólidos, dos efluentes domésticos, e nas condições climáticas, entre outros aspectos, recomenda-se que próximos estudos aprofundem a caracterização do substrato, do biogás gerado, os padrões de comportamento, e análise da sazonalidade das propriedades físico químicas do esgoto nos municípios, de forma a auxiliar na definição de condições ótimas de produção de biogás e dimensionamento das plantas. Além disto, seria importante realizar coleta e análise dos parâmetros do biogás gerado na ETE Vinhais, principalmente no que se refere à qualidade do biogás na quantidade de metano.

- Parceria para preenchimento e atualizaçãos do sistema estadual de informações sobre saneamento

Frente ao desafio político administrativo e institucional apresentado pela Lei das Estatais e o Marco Regulatório do Saneamento, a disponibilização das informações atualizadas sobre os sistemas de saneamento básico nos municípios brasileiros é fundamental para se traçar estratégias para que se alcance a meta da universalização dos serviços, como projetado pela Agenda 2033. Com a estratégia de preenchimento frequente do sistema estadual de informações, o qual poderia ser pensado junto ao Instituto Maranhense de Estudos Socioeconômicos e Cartográficos (IMESC) e a Agência Reguladora do Estado (MOB), seria possível fazer o acompanhamento mensal das informações e indicadores, otimizando a prestação de serviços e fiscalização destes pelas agências reguladoras, assim como, facilitando o controle social. Atualmente, o SNIS disponibiliza as informações anualmente, e apresenta inconsistências relevantes que precisam ser corrigidas.

- Criação de base de dados para todas as ETEs do Brasil, em complemento às informações da ANA do Atlas Esgoto;

A disponibilização de informações sobre o tipo de tecnologia, condições de operação e localização das ETEs facilitaria o desenvolvimento de políticas públicas mais próximas da realidade existente. Seria importante vincular os atores para manterem estas informações atualizadas e disponíveis para a população e para as próprias instituições.

- Criação de indicador de viabilidade de uso de tecnologias de recuperação energética a partir de resíduos; 
Considerando que são diversos os aspectos que influenciam a viabilidade do uso da recuperação energética, é preciso aprofundar o estudo da definição destes aspectos, bem como a correlação com a realidade atual, para a definição de pesos, e possivelmente a criação de um indicador que facilite a tomada de decisão por parte dos gestores. Este indicador preliminar teria como base os parâmetros técnicos, territoriais, econômicos, sociais e ambientais, de forma a indicar a viabilidade da implantação de tecnologias de recuperação energética. 
Referências bibliográficas ${ }^{3}$

AGÊNCIA NACIONAL DE ÁGUAS - ANA. Atlas Esgotos - Despoluição de Bacias Hidrográficas. Brasília: [s.n.], 2017.

AGÊNCIA NACIONAL DE ENERGIA ELÉTRICA - ANEEL. Banco de Informações de Geração (BIG). Disponível

em:

$<$ http://www2.aneel.gov.br/aplicacoes/capacidadebrasil/OperacaoCapacidadeBrasil.cfm>.

Acesso em: 10 out. 2018.

AGÊNCIA NACIONAL DE PETRÓLEO ANP. RESOLUÇÃO No 685, 2017. Resolução Anp $N^{o}$ 685, De 29.6.2017 - Dou 30.6.2017. [S.1: s.n.]. Disponível em: $<$ http://legislacao.anp.gov.br/?path=legislacao-anp/resol-anp/2017/junho\&item=ranp-685-2017>. , 2017

AGÊNCIA REGULADORA DE SERVIÇOS PÚBLICOS DELEGADOS DO MUNICÍPIO DE TIMON - AGERT. Site AGERT. Disponível em: $<$ http://www.agert.com.br/index.php/about>. Acesso em: 28 mar. 2020.

ÁGUAS DE TIMON. Site Águas de Timon. Disponível em: <https://aguasdetimon.com.br/>. Acesso em: 28 mar. 2020.

APPELS, Lise et al. Anaerobic digestion in global bio-energy production: Potential and research challenges. Renewable and Sustainable Energy Reviews, v. 15, n. 9, p. 4295-4301, 2011.

ARASHIRO, Larissa Terumi et al. Life cycle assessment of high rate algal ponds for wastewater treatment and resource recovery. Science of the Total Environment, v. 622-623, p. 1118-1130, 2018. Disponível em: <https://doi.org/10.1016/j.scitotenv.2017.12.051>.

ASSOCIAÇÃO BRASILEIRA DE BIOGÁS E BIOMETANO - ABIOGAS. Biogás e biometano. Disponível em: $<$ https://abiogas.org.br/biogas-e-biometano $>$. Acesso em: 3 maio 2019.

ASSOCIAÇÃO BRASILEIRA DE BIOGÁS E BIOMETANO - ABIOGAS. Usinas Saneamento Ambiental. . [S.1: s.n.]. , 2020

ASSOCIAÇÃO BRASILEIRA DE EMPRESAS DE LIMPEZA PÚBLICA E RESÍDUOS ESPECIAIS - ABRELPE. Panorama dos Resíduos Sólidos no Brasil 2018/2019. . [S.1: s.n.], 2019. Disponível em: <http://abrelpe.org.br/download-panorama-2018-2019/>.

ASSOCIAÇÃO BRASILEIRA DE EMPRESAS DE TRATAMENTO DE RESÍDUOS ABETRE. Recuperação Energética de Resíduos Sólidos Urbanos. Disponível em:

\footnotetext{
${ }^{3}$ ABN: NBR: Informação e documentação - Referências - Elaboração. 2018
} 
$<\mathrm{http}$ //www.abetre.org.br/a-abetre/opiniao/recuperacao-energetica-de-residuos $>$. Acesso em: 6 jan. 2019.

ASSOCIAÇÃO BRASILEIRA DE SANEAMENTO BÁSICO EESTADUAIS - AESBE. Paraná terá a $1^{a}$ usina do Brasil a gerar biogás por meio de esgoto e lixo. Disponível em: $<$ http://www.aesbe.org.br/parana-tera-a-1a-usina-do-brasil-a-gerar-biogas-por-meio-deesgoto-e-lixo/>. Acesso em: 18 mar. 2019.

ASSOCIAÇÃO BRASILEIRA NORMAS TÉCNICAS - ABNT. NBR 10004 - Resíduos sólidos - Classificação. 2004.

ASSOCIAÇÃO BRASILEIRA NORMAS TÉCNICAS - ABNT. NBR 7229: Projeto, construção e operação de sistemas de tanques sépticos. p. 15, 1993.

ASSOCIAÇÃO BRASILEIRA NORMAS TÉCNICAS - ABNT. Planejamento de Amostragem de Efluentes Líquidos e Corpos Receptores NBR 9897. 1987a.

ASSOCIAÇÃO BRASILEIRA NORMAS TÉCNICAS - ABNT. Preservação e técnicas de amostragem de efluentes e corpos receptores - NBR 9898. p. 22, $1987 \mathrm{~b}$.

AYMERICH, I et al. ScienceDirect The difference between energy consumption and energy cost : Modelling energy tariff structures for water resource recovery facilities. Water Research, v. 81, p. 113-123, 2015. Disponível em: <http://dx.doi.org/10.1016/j.watres.2015.04.033>.

BILOTTA, Patrícia; ROSS, Bárbara Zanicotti Leite. Estimate of energy generation and of greenhouse gas emission on biogas recovery from wastewater treatment plant. Engenharia Sanitaria e Ambiental, v. 21, n. 2, p. 275-282, 2016.

BRASIL. MINISTÉRIO DAS CIDADES. PROBIOGAS - Guia Técnico de Aproveitamento Energético de Biogás em Estações de Tratamento de Esgoto. [S.1: s.n.], 2015.

BRASIL. MINISTÉRIO DAS CIDADES. SECRETARIA NACIONAL DE SANEAMENTO AMBIENTAL. Diagnóstico dos Serviços de Água e Esgoto - 2018. p. 220, 2018. Disponível em: <http://snis.gov.br/diagnostico-agua-e-esgotos/diagnostico-ae-2016\%0A $>$.

BRASIL. Lei 12.305/2010 - Política Nacional dos Resíduos Sólidos. . [S.1: s.n.]. , 2010

BREACH, Patrick A. Wastewater Treatment Energy Recovery Potential For Adaptation To Global Change : An Integrated Assessment. Environmental Management, p. 624-636, 2018. Disponível em: <http://dx.doi.org/10.1007/s00267-018-0997-6>.

BRK AMBIENTAL. Quem somos? BRK Ambiental. Disponível em: $<$ https://www.brkambiental.com.br/>. Acesso em: 28 mar. 2020.

CABRAL, Carolina Bayer Gomes. AVALIAÇÃO DA PRODUÇÃO DE BIOGÁS PARA FINS ENERGÉTICOS EM REATORES ANAERÓBIOS TRATANDO ESGOTO SANITÁRIO. . [S.1: s.n.], 2016. 
CANCELLI, Thiago. Geração de energia a partir do biogás de estações de tratamento de esgoto doméstico. 2013.

CASAROTTO FILHO, N.; KOPITTKE, B. H. Análise de investimentos: matemática financeira, engenharia econômica, tomada de decisão, estratégia empresarial. [S.1: s.n.], 2007. CASHMAN, Sarah et al. Energy and greenhouse gas life cycle assessment and cost analysis of aerobic and anaerobic membrane bioreactor systems: Influence of scale, population density, climate, and methane recovery. Bioresource Technology, v. 254, n. January, p. 56-66, 2018. Disponível em: <https://doi.org/10.1016/j.biortech.2018.01.060>.

CENTRO INTERNACIONAL DE ENERGIAS RENOVÁVEIS - CIBIOGAS. Biogasmap. Disponível em: <http://mapbiogas.cibiogas.org/>. Acesso em: 10 ago. 2019.

CENTRO INTERNACIONAL DE ENERGIAS RENOVÁVEIS - CIBIOGAS. Nota técnica 02/2019 - O panorama do mercado de alimentos no Brasil em 2018. . [S.1: s.n.], 2018.

CERVI, Ricardo Ghantous. Avaliação Econômica Do Aproveitamento Do Biogás E Biofertilizante Produzido Por Biodigestão Anaeróbia. . [S.1: s.n.], 2009.

CETESB, Companhia de Tecnologia de Saneamento Ambiental. Biogas - Pesquisas e projetos no Brasil. . [S.1: s.n.], 2006.

CHEN, Lin et al. Performance of a submerged anaerobic membrane bioreactor with forward osmosis membrane for low-strength wastewater treatment. Water Research, v. 50, p. 114-123, 2014.

CHEN, Shaoqing; CHEN, Bin. Net energy production and emissions mitigation of domestic wastewater treatment system: A comparison of different biogas-sludge use alternatives. Bioresource Technology, v. 144, p. 296-303, 2013. Disponível em: $<\mathrm{http}: / / \mathrm{dx}$.doi.org/10.1016/j.biortech.2013.06.128>.

CIBIOGÁS, Centro Internacional do Biogás. Nota Técnica: $N^{\circ}$ 002/2020 - Panorama do Biogás no Brasil em 2019. . [S.1: s.n.], 2020.

CIRNE, José Raniery Rodrigues et al. Biorreatores Anaeróbios de Membrana Dinâmica no Tratamento de Águas Residuárias: Revisão. 2019, [S.1: s.n.], 2019. p. 1-28.

CNM - CONFEDERAÇÃO NACIONAL DOS MUNICÍPIOS. Durante a Marcha, Câmara aprova urgência de PL que prorroga prazo para fim dos lixões. Disponível em: $<$ https://www.cnm.org.br/comunicacao/noticias/durante-a-marcha-camara-aprova-urgenciapara-pl-que-prorroga-prazo-para-fim-dos-lixoes>. Acesso em: 6 jun. 2020.

CNM - CONFEDERAÇÃO NACIONAL DOS MUNICÍPIOS -. Pacto Federativo. Disponível em: $\quad<$ https://www2.camara.leg.br/atividade-legislativa/comissoes/comissoestemporarias/especiais/55a-legislatura/pacto-federativo/documentos/audiencias-publicas/14- 
04-2015-apresentacao-do-sr-paulo-ziulkoski-presidente-da-cnm>. Acesso em: 28 mar. 2020. CODEVASF. CODEVASF. Disponível em: <https://www.codevasf.gov.br/acesso-ainformacao/institucional/historia/historia>. Acesso em: 25 jul. 2020.

COELHO, Suani Teixeira; et Al. Instalação e testes de uma unidade de demonstração de geração de energia elétrica a partir de biogás de tratamento de esgoto. ENCONTRO DE ENERGIA NO MEIO RURAL, 5, 2004.

COELHO, Suani Teixeira; VELAZQUEZ, Sílvia Maria Stortini González; SILVA, Orlando Cristiano. Geração de energia elétrica a partir do biogás proveniente do tratamento de esgoto. 2006, Campinas: [s.n.], 2006.

COMPANHIA AMBIENTAL DO ESTADO DE SÃO PAULO - CETESB. Reatores. Disponível em: <https://cetesb.sp.gov.br/biogas/biogas/reatores/>. Acesso em: 16 fev. 2019. COMPANHIA DE SANEAMENTO AMBIENTAL DO MARANHÃO - CAEMA. Carta Anual 2018. . [S.1: s.n.], 2018.

CONSÓRCIO INTERMUNICIPAL DE SANEAMENTO BÁSICO - CISAB. Protocolo de Intenções - CISAB - PRÓ-CIDADE. . [S.1: s.n.]. , 2014

CORNEJO, Pablo K.; ZHANG, Qiong; MIHELCIC, James R. Quantifying benefits of resource recovery from sanitation provision ina developing world setting. Journal of Environmental Management, $\quad$ v. 131, p. 7-15, 2013. Disponível em: $<$ http://dx.doi.org/10.1016/j.jenvman.2013.09.043>.

CORNELLI, Renata; ALEGRE, Porto. Análise e seleção de alternativas sustentáveis de esgotamento sanitário. 2014.

CUTRIM, Ana Maria França. APROVEITAMENTO ENERGÉTICO DO BIOGÁS GERADO NO TRATAMENTO DE EFLUENTES URBANOS. . [S.1: s.n.], 2012.

D’AQUINO, Camila Agner. Geração de energia por biogás a partir de resíduos orgânicos: Estudo de caso da cidade universitária da USP. 2018. Universidade de São Paulo, 2018.

DE QUEIROZ, Camila Kelly; PAES, Juliana Lobo; FERNANDES, Pedro Luis Belfort Gomes. Caracterização Da Produção De Biogás a Partir Da Biodigestão De Lodo De Esgoto. VII Congresso Brasileiro de Energia Solar-CBENS 2018, n. Mdl, 2018.

DI MARIA, Francesco et al. Amount of energy recoverable from an existing sludge digester with the co-digestion with fruit and vegetable waste at reduced retention time. Applied Energy, v. 150, p. 9-14, 2015. Disponível em: <http://dx.doi.org/10.1016/j.apenergy.2015.01.146>.

DI MARIA, Francesco; MICALE, Caterina; CONTINI, Stefano. Energetic and environmental sustainability of the co-digestion of sludge with bio-waste in a life cycle perspective. Applied Energy, v. 171, p. 67-76, 2016. Disponível em: 
$<\mathrm{http} / / / \mathrm{dx}$.doi.org/10.1016/j.apenergy.2016.03.036>.

DIAS, Maria Isabel Alencar et al. Viabilidade Econômica Do Uso Do Biogás Proveniente Da Economic Feasibility of the Use of Biogas Produced From Swine Culture in. Revista .Energia Na Agricultura, v. 28, p. 155-164, 2013.

DÜRRENMATT, David J.; WANNER, Oskar. A mathematical model to predict the effect of heat recovery on the wastewater temperature in sewers. Water Research, v. 48, n. 1, p. 548$558,2014$.

EPE. Balanço energético nacional: Ano base 2018. EPE - Empresa de Pesquisa Energética, p. $67,2019$.

EPE. Matriz Energética e Elétrica. Disponível em: $<$ http://www.epe.gov.br/pt/abcdenergia/matriz-energetica-e-eletrica $>$. Acesso em: 6 jun. 2020. ESPERANCINI, Maura S.T. et al. Viabilidade técnica e econômica da substituição de fontes convencionais de energia por biogás em assentamento rural do Estado de São Paulo. Engenharia Agricola, v. 27, n. 1, p. 110-118, 2007.

FERNÁNDEZ-ARÉVALO, T. et al. Quantitative assessment of energy and resource recovery in wastewater treatment plants based on plant-wide simulations. Water Research, v. 118, p. 272-288, 2017.

FIRMO, Alessandra Lee Barbosa. ESTUDO NUMÉRICO E EXPERIMENTAL DA GERAÇÃO DE BIOGÁS A PARTIR DA BIODEGRADAÇÃO DE RESÍDUOS SÓLIDOS URBANOS. 2013.

FLORES-ALSINA, Xavier et al. Balancing efluent quality, economic cost and greenhouse gas emissions during the evaluation of ( plant-wide ) control / operational strategies in WWTPs. Science of the Total Environment, The, v. 466-467, p. 616-624, 2014. Disponível em: $<$ http://dx.doi.org/10.1016/j.scitotenv.2013.07.046>.

FOLEY, Jeffrey et al. Comprehensive life cycle inventories of alternative wastewater treatment systems. Water Research, v. 44, n. 5, p. 1654-1666, 2010. Disponível em: $<$ http://dx.doi.org/10.1016/j.watres.2009.11.031>.

FUNASA, Fundação Nacional de Saúde. Manual de Orientação para Criação e Organização de Autarquias Municipais de Água e Esgoto. Disponível em: $<$ http://bvsms.saude.gov.br/bvs/publicacoes/funasa/man_autarq_agua_esgoto.pdf $>$. Acesso em: 31 maio 2020.

GAO, Da-wen et al. Sewage treatment by an UAFB - EGSB biosystem with energy recovery and autotrophic nitrogen removal under different temperatures. Bioresource Technology, v. 181, p. 26-31, 2015. Disponível em: <http://dx.doi.org/10.1016/j.biortech.2015.01.037>. 
GONZÁLEZ-FERNÁNDEZ, Cristina; GARCÍA-ENCINA, Pedro A. Impact of substrate to inoculum ratio in anaerobic digestion of swine slurry. Biomass and Bioenergy, v. 33, n. 8, p. 1065-1069, 2009.

GOODMAN, Leo A. Snowball Sampling. Disponível em: $<$ https://www.jstor.org/stable/2237615?seq=1>. Acesso em: 9 maio 2020.

GREENE, Jennifer C; CARACELLI, Valerie J; GRAHAM, Wendy F. Toward a Conceptual Framework for Mixed-Method Evaluation Designs. American Educational Reserach Association, v. 11, n. 3, p. 255-274, 1989.

GROBELAK, Anna; GROSSER, Anna; KAMIZELA, Tomasz. Sewage sludge processing and management in small and medium-sized municipal wastewater treatment plant-new technical solution. v. 234, n. December 2018, p. 90-96, 2019.

GU, Jun; XU, Guangjing; LIU, Yu. An integrated AMBBR and IFAS-SBR process for municipal wastewater treatment towards enhanced energy recovery, reduced energy consumption and sludge production. Water Research, v. 110, p. 262-269, 2017. Disponível em: $<\mathrm{http}: / / \mathrm{dx}$.doi.org/10.1016/j.watres.2016.12.031>.

HIEGEMANN, Heinz et al. Bioresource Technology An integrated 45 L pilot microbial fuel cell system at a full-scale wastewater treatment plant. Bioresource Technology, v. 218, p. 115122, 2016. Disponível em: <http://dx.doi.org/10.1016/j.biortech.2016.06.052>.

INCT, Etes Sustentáveis. Tratamentos anaeróbios de esgoto. Disponível em: $<$ https://etessustentaveis.org/metodos-tratamento-de-esgoto/>.

INSTITUTO BRASILEIRO DE GEOGRAFIA E ESTATÍSTICA - IBGE. Censo 2010. Disponível em: <https://censo2010.ibge.gov.br/>. Acesso em: 2 fev. 2019.

INSTITUTO BRASILEIRO DE GEOGRAFIA E ESTATÍSTICA - IBGE. Estimativas de população. Disponível em: <https://www.ibge.gov.br/estatisticas/sociais/populacao/9103estimativas-de-populacao.html? $=\& \mathrm{t}=$ resultados $>$.

INSTITUTO BRASILEIRO DE GEOGRAFIA E ESTATÍSTICA - IBGE. Pesquisa de Informações Básicas Municipais - MUNIC 2017.

IPCC. IPCC Guidelines for National Greenhouse Gas Inventories. . [S.1: s.n.], 2006. Disponível em: <https://www.ipcc-nggip.iges.or.jp/public/2006gl/>.

ISHII, Shun'ichi et al. Identifying the microbial communities and operational conditions for optimized wastewater treatment in microbial fuel cells. Water Research, v. 47, n. 19, p. 7120 7130, 2013. Disponível em: <http://dx.doi.org/10.1016/j.watres.2013.07.048>.

JEONG, Yeongmi; HERMANOWICZ, Slawomir W; PARK, Chanhyuk. Treatment of food waste recycling wastewater using anaerobic ceramic membrane bioreactor for biogas 
production in mainstream treatment process of domestic wastewater. Water Research, v. 123, p. 86-95, 2017. Disponível em: <http://dx.doi.org/10.1016/j.watres.2017.06.049>.

JIANG, Yuyuan et al. Energy footprint and carbon emission reduction using off-the-grid solarpowered mixing for lagoon treatment. Journal of Environmental Management, v. 205, p. 125$133,2018$.

JOHNSON, Burke; CHRISTENSEN, Larry. Educational Research: Quantitative, Qualitative and Mixed Approaches. 5th. ed. Thousand Oaks, California: SAGE Publications, Inc., 2014.

JORDAO, Eduardo Pacheco; PESSOA, Constatino Arruda. Tratamento de Esgotos Domésticos. [S.1: s.n.], 2017.

KERSTENS, S. M.; LEUSBROCK, I.; ZEEMAN, G. Feasibility analysis of wastewater and solid waste systems for application in Indonesia. Science of the Total Environment, v. 530-531, p. 53-65, 2015. Disponível em: <http://dx.doi.org/10.1016/j.scitotenv.2015.05.077>.

KHAN, M Z et al. Microbial electrolysis cells for hydrogen production and urban wastewater treatment : A case study of Saudi Arabia. Applied Energy, v. 185, p. 410-420, 2017. Disponível em: <http://dx.doi.org/10.1016/j.apenergy.2016.11.005>.

KHIEWWIJIT, Rungnapha et al. Environmental Modelling \& Software Energy and nutrient recovery for municipal wastewater treatment: How to design a feasible plant layout? Environmental Modelling \& Software, v. 68, p. 156-165, 2015.

KHIEWWIJIT, Rungnapha et al. Glocal assessment of integrated wastewater treatment and recovery concepts using partial nitritation/Anammox and microalgae for environmental impacts. Science of the Total Environment, v. 628-629, p. 74-84, 2018. Disponível em: $<$ https://doi.org/10.1016/j.scitotenv.2018.01.334>.

LAM, Ka Leung; KENWAY, Steven J.; LANT, Paul A. City-scale analysis of water-related energy identifies more cost-effective solutions. Water Research, v. 109, p. 287-298, 2017.

LANE, J. L.; DE HAAS, D. W.; LANT, P. A. The diverse environmental burden of city-scale urban water systems. Water Research, v. 81, p. 398-415, 2015. Disponível em: $<$ http://dx.doi.org/10.1016/j.watres.2015.03.005>.

LARAMEE, Jeannette; TILMANS, Sebastien; DAVIS, Jennifer. Costs and bene fi ts of biogas recovery from communal anaerobic digesters treating domestic wastewater: Evidence from peri-urban Zambia. Journal of Environmental Management, v. 210, p. 23-35, 2018. Disponível em: $<$ https://doi.org/10.1016/j.jenvman.2017.12.064>.

LARSEN, Tove A. CO 2 -neutral wastewater treatment plants or robust, climate-friendly wastewater management? A systems perspective. Water Research, v. 87, p. 513-521, 2015. Disponível em: <http://dx.doi.org/10.1016/j.watres.2015.06.006>. 
LE-CLECH, Pierre; CHEN, Vicki; FANE, Tony A.G. Fouling in membrane bioreactors used in wastewater treatment. Journal of Membrane Science, v. 284, n. 1-2, p. 17-53, 2006.

LIANG, Peng et al. One-year operation of 1000-L modularized microbial fuel cell for municipal wastewater treatment. Water Research, v. 141, p. 1-8, 2018. Disponível em: $<$ https://doi.org/10.1016/j.watres.2018.04.066>

LIMA, Ana Carolina Guedes; PASSAMANI, Fernanda Caliman. AVALIAÇÃO DO POTENCIAL ENERGÉTICO DO BIOGÁS PRODUZIDO NO REATOR UASB DA ETEUFES AVALIAÇÃO DOPOTENCIAL ENERGÉTICO DO BIOGÁS PRODUZIDO NO REATOR UASB DA ETE-UFES. 2012.

LIU, Beibei et al. Life cycle GHG emissions of sewage sludge treatment and disposal options in Tai Lake Watershed, China. Science of the Total Environment, v. 447, p. 361-369, 2013.

LIU, Guangqing et al. Effect of feed to inoculum ratios on biogas yields of food and green wastes. Bioresource Technology, v. 100, n. 21, p. 5103-5108, 2009.

LIU, Jinmeng et al. Integrating microbial fuel cells with anaerobic acidi fi cation and forward osmosis membrane for enhancing bio-electricity and water recovery from low-strength wastewater. Water Research, v. 110, p. 74-82, 2017. Disponível em: $<\mathrm{http}: / / \mathrm{dx}$.doi.org/10.1016/j.watres.2016.12.012>.

LOBATO, Lívia Cristina da Silva. Aproveitamento energético de biogás gerado em reatores uasb tratando esgoto doméstico. . [S.1: s.n.], 2011.

LOPES, Lucas Sampaio. AVALIAÇÃO DO POTENCIAL DE RECUPERAÇÃO REATORES UASB TRATANDO ESGOTO DOMÉSTICO NO ESTADO DO PARANÁ. . [S.1: s.n.], 2018.

LUMLEY, Nicholas P G et al. Bioresource Technology Techno-economic analysis of wastewater sludge gasification: A decentralized urban perspective. BIORESOURCE TECHNOLOGY, v. 161, p. 385-394, 2014. Disponível em: $<$ http://dx.doi.org/10.1016/j.biortech.2014.03.040>.

MARIANI, Leidiane. Biogás : diagnóstico e propostas de ações para incentivar seu uso no Brasil Biogás : diagnóstico e propostas de ações para incentivar seu uso no Brasil. 2018. UNICAMP, 2018.

MARIANI, Leidiane; KAZUE NAKAO CAVALIERO, Carla. Biogás: diagnóstico e propostas de ações para incentivar seu uso no Brasil. p. 144, 2018. Disponível em: $<$ http://repositorio.unicamp.br/bitstream/REPOSIP/333144/1/Mariani_Leidiane_D.pdf $>$.

MCCARTY, Perry L; BAE, Jaeho; KIM, Jeonghwan. Domestic Wastewater Treatment as a Net Energy Producer À Can This be Achieved? Environmental Science \& Technology, 2011.

MEERBURG, Francis A. et al. Toward energy-neutral wastewater treatment: A high-rate 
contact stabilization process to maximally recover sewage organics. Bioresource Technology, v. 179, p. 373-381, 2015. Disponível em: <http://dx.doi.org/10.1016/j.biortech.2014.12.018>. MENEZES, Mayara Beuttenmuller Castro. Aproveitamento dos efluentes domésticos para geração de energia em condomínios residenciais de baixa renda Maceió Aproveitamento dos efluentes domésticos para geração de energia em condomínios residenciais de baixa renda Maceió. . [S.1: s.n.], 2016.

MERCEDES, Sonia Seger. Ánálise comparativa dos serviços públicos de eletricidade e saneamento básico no Brasil: ajustes liberais e desenvolvimento. 2002. 506 f. 2002.

MEZOHEGYI, G.; BILAD, M. R.; VANKELECOM, Ivo F.J. Direct sewage up-concentration by submerged aerated and vibrated membranes. Bioresource Technology, v. 118, p. 1-7, 2012. Disponível em: <http://dx.doi.org/10.1016/j.biortech.2012.05.022>.

MINISTÉRIO DAS CIDADES. Plano Nacional de Saneamento Básico - PLANSAB -. . [S.1: s.n.]. , 2013

MO, Weiwei; ZHANG, Qiong. Can municipal wastewater treatment systems be carbon neutral? Journal of Environmental Management, v. 112, p. 360-367, 2012.

MOUKAZIS, Ioannis; PELLERA, Frantseska Maria; GIDARAKOS, Evangelos. Slaughterhouse by-products treatment using anaerobic digestion. Waste Management, v. 71, p. 652-662, 2018. Disponível em: <https://doi.org/10.1016/j.wasman.2017.07.009>.

MUGA, Helen E; MIHELCIC, James R. Sustainability of wastewater treatment technologies. Journal of Environmental Management, v. 88, p. 437-447, 2008.

NANSUBUGA, Irene et al. Digestion of high rate activated sludge coupled to biochar formation for soil improvement in the tropics. Water Research, v. 81, p. 216-222, 2015. Disponível em: $<$ http://dx.doi.org/10.1016/j.watres.2015.05.047>.

NBS ENGENHARIA. Relatório Técnico ETE Bacanga São Luís -MA. . [S.1: s.n.], 2018a.

NBS ENGENHARIA. Relatório Técnico ETE Vinhais São Luís -MA. . [S.1: s.n.], 2018b.

NEUENDORF, Kimberly A. The Content Analysis Guidebook. 2nd. ed. Los Angeles: SAGE Publications, Inc., 2017.

NOGUEIRA, E. Análise de investimentos. [S.1: s.n.], 2009.

OKOLI, Chitu; SCHABRAM, Kira. A Guide to Conducting a Systematic Literature Review of Information Systems Research. Sprouts, v. 10, n. 2010, 2010.

OLIVEIRA, Sílvia M. A. Correia; SPERLING, Marcos Von. Evaluation of 166 treatment plants operating in Brazil, comprising several technologies. Part 1-Performance analysis. Eng. sanit. ambient, v. 10, n. 4, p. 347-357, 2005.

ONU, Organização das Nações Unidas. Objetivos do Desenvolvimento Sustentável. Disponível 
em: $<$ https://brasil.un.org/>. Acesso em: 16 nov. 2020.

OON, Yoong-ling et al. Bioresource Technology Role of macrophyte and effect of supplementary aeration in up-flow constructed wetland-microbial fuel cell for simultaneous wastewater treatment and energy recovery. Bioresource Technology, v. 224, p. 265-275, 2017. Disponível em: <http://dx.doi.org/10.1016/j.biortech.2016.10.079>.

OON, Yoong-ling et al. Synergistic effect of up-flow constructed wetland and microbial fuel cell for simultaneous wastewater treatment and energy recovery. Bioresource Technology, v. 203, p. 190-197, 2016. Disponível em: <http://dx.doi.org/10.1016/j.biortech.2015.12.011>.

PAPA, Matteo et al. How far are we from closing the loop of sewage resource recovery? A real picture of municipal wastewater treatment plants in Italy. Journal of Environmental Management, v. 198, p. 9-15, 2017. Disponível em: $<$ http://dx.doi.org/10.1016/j.jenvman.2017.04.061>.

PECORA, Vanessa. Implantação de uma Unidade Demosntrativa de Geração de Energia Elétrica a partir do Biogás de Tratamento do Esgoto Residencial da USP - estudo de caso. Dissertação de mestrado, v. 53, p. 1689-1699, 2006. Disponível em: $<$ http://www.iee.usp.br/producao/2006/Teses/tese_vanessapecora.pdf $>$.

PELLERA, F.-M.; GIDARAKOS, E. Effect of substrate to inoculum ratio and inoculum type on the biochemical methane potential of solid agroindustrial waste. 2016.

PERUZZO, Vanessa Verona. Estudo da acidogênese e metanogênese aplicada no tratamento da vinhaça da cana de açúcar. 2017. 115 f. Universidade Caxias do Sul, 2017.

PNUD. Atlas do Desenvolvimento Humano no Brasil. Disponível em: $<$ http://atlasbrasil.org.br/2013/pt/ranking > . Acesso em: 2 mar. 2019.

PNUD; MMA. Produto 6 - Resumo Executivo Estudo sobre o Potencial de Geração de Energia a partir de Resíduos de Saneamento (lixo, esgoto), visando incrementar o uso de biogás como fonte alternativa de energia renovável. p. 56, 2010.

PORTAL TRATAMENTO DE ÁGUA. Lagoas de estabilização. Disponível em: $<$ https://www.tratamentodeagua.com.br/artigo/lagoas-estabilizacao/>. Acesso em: 15 fev. 2020.

PORTAL TRATAMENTO DE ÁGUA. MBR: nova tecnologia para tratamento de efluentes.

Disponível em: <https://www.tratamentodeagua.com.br/artigo/mbr-nova-tecnologia-paratratamento-de-efluentes/>. Acesso em: 12 abr. 2020.

POSSETTI, Gustavo Rafael Collere et al. MEDIÇÕES EM TEMPO REAL DO BIOGÁS PRODUZIDO EM REATORES UASB ALIMENTADOS COM ESGOTO DOMÉSTICO. 2013, [S.1: s.n.], 2013. p. 1-7. 
PRETEL, R. et al. Environmental impact of submerged anaerobic MBR (SAnMBR) technology used to treat urban wastewater at different temperatures. Bioresource Technology, v. 149, p. 532-540, 2013. Disponível em: <http://dx.doi.org/10.1016/j.biortech.2013.09.060>.

PRETEL, R. et al. Navigating environmental, economic, and technological trade-offs in the design and operation of submerged anaerobic membrane bioreactors (AnMBRs). Water Research, v. 87, p. 531-541, 2015.

PROUTY, Christine; MOHEBBI, Shima; ZHANG, Qiong. Socio-technical strategies and behavior change to increase the adoption and sustainability of wastewater resource recovery systems. Water Research, v. 137, p. 107-119, 2018. Disponível em: $<$ https://doi.org/10.1016/j.watres.2018.03.009>.

RASI, S.; VEIJANEN, A.; RINTALA, J. Trace compounds of biogas from different biogas production plants. Energy, v. 32, n. 8, p. 1375-1380, 2007.

RESCH, Gustav et al. Potentials and prospects for renewable energies at global scale. v. 36, p. 4048-4056, 2008.

ROGGE, Nicky; DE JAEGER, Simon. Evaluating the efficiency of municipalities in collecting and processing municipal solid waste: A shared input DEA-model. Waste Management, v. 32, n. 10, p. 1968-1978, 2012. Disponível em: <http://dx.doi.org/10.1016/j.wasman.2012.05.021>. ROSA, André Pereira et al. Potencial energético e alternativas para o aproveitamento do biogás e lodo de reatores UASB : estudo de caso Estação de tratamento de efluentes Laboreaux ( Itabira ). p. 315-328, 2016.

RUNESON, Per;; HÖST, Martin; Guidelines for conducting and reporting case study research in software engineering. [S.1.]: Empirical Software Engineering, 2009.

SAMPAIO, R F; MACINI, M C. Estudos de revisão sistemática: Um guia para a síntese criteriosa da evidência científica. Rev. bras. fisioter, p. 83-89, 2007. Disponível em: $<$ www.bireme.br>.

SANCHES-PEREIRA, Alessandro et al. Fostering local sustainable development in Tanzania by enhancing linkages between tourism and small-scale agriculture. v. 162, p. 1567-1581, 2017.

SANCHES-PEREIRA, Alessandro; TUDESCHINI, Luís Gustavo; COELHO, Suani Teixeira. Evolution of the Brazilian residential carbon footprint based on direct energy consumption. Renewable and Sustainable Energy Reviews, v. 54, p. 184-201, 2016.

SANEPAR. MANUAL DE PROJETOS DE SANEAMENTO. p. 1-29, 2017.

SANEPAR. Resumo Técnico - $4^{o}$ Workshop Intenacional de Aproveitamento Energético de Biogás de ETEs. . [S.1: s.n.], 2016. 
SATO, Toshio; QADIR, Manzoor; YAMAMOTO, Sadahiro. Global, regional, and country level need for data on wastewater generation, treatment, and use. Agricultural Water Management, v. 130, p. 1-13, 2013. Disponível em: $<$ http://dx.doi.org/10.1016/j.agwat.2013.08.007>.

SCHEUER, Alex. Geração de energia elétrica a partir de biogás produzido em estações de tratamento de esgoto. . [S.1: s.n.], 2019.

SECRETARIA DO ESTADO DAS CIDADES - SECID. Região Metropolitana da Grande São Luís. Disponível em: <https://secid.ma.gov.br/2019/05/27/com-estudos-e-mapeamentogoverno-direciona-programas-para-regiao-metropolitana-da-grande-sao-luis/>. Acesso em: 28 mar. 2020.

SECRETARIA DO MEIO AMBIENTE E RECURSOS HÍBRICO - SEMARH. Recuperação Energética. Disponível em: <http://www.residuossolidos.al.gov.br/sistemas/recuperacaoenergetica>. Acesso em: 6 jan. 2019.

SHIRADO, Jacqueline. ANÁLISE DOS FLUXOS DE MATERIAIS E DE ENERGIA COMO FERRAMENTA. . [S.1: s.n.], 2014.

SIGNIFICADOS. Efluentes domésticos. Disponível em: $<$ https://www.significados.com.br/efluentes-domesticos/>.

SILVA, Carlos Ernando. Principais Características Físicas dos Esgotos Domésticos. . Santa Maria/RS: [s.n.]. Disponível em: <http://jararaca.ufsm.br/websites/ces/download/A1.pdf>. , 2020

SILVA, Thaisa Carolina Ferreira. Utilização de biogás de estações de tratamento de esgoto para fins energéticos. p. 152, 2015.

SISTEMA NACIONAL DE INFORMAÇÃO DE SANEAMENTO - SNIS. Diagóstico do Manejo de Resíduos Sólidos Urbanos - 2018. . [S.1: s.n.], 2018. Disponível em: $<$ http://www.snis.gov.br/diagnostico-anual-residuos-solidos/diagnostico-do-manejo-deresiduos-solidos-urbanos-2018>.

SISTEMA NACIONAL DE INFORMAÇÕES SOBRE SANEAMENTO - SNIS. Diagnóstico dos Serviços de Água e Esgotos. . [S.1: s.n.], 2019. Disponível em: $<$ http://www.snis.gov.br/diagnosticos>.

SMITH, Adam L. et al. Navigating wastewater energy recovery strategies: A life cycle comparison of anaerobic membrane bioreactor and conventional treatment systems with anaerobic digestion. Environmental Science and Technology, v. 48, n. 10, p. 5972-5981, 2014. SMITH, Adam L. et al. Perspectives on anaerobic membrane bioreactor treatment of domestic wastewater: A critical review. Bioresource Technology, v. 122, p. 149-159, 2012a. Disponível 
em: <http://dx.doi.org/10.1016/j.biortech.2012.04.055>.

SMITH, Adam L et al. Perspectives on anaerobic membrane bioreactor treatment of domestic wastewater: A critical review. Bioresource Technology, v. 122, p. 149-159, 2012b. Disponível em: <http://dx.doi.org/10.1016/j.biortech.2012.04.055>.

SONG, Xiaoye et al. An anaerobic membrane bioreactor - membrane distillation hybrid system for energy recovery and water reuse: Removal performance of organic carbon, nutrients, and trace organic contaminants. Science of the Total Environment, v. 628-629, p. 358-365, 2018. Disponível em: <https://doi.org/10.1016/j.scitotenv.2018.02.057>.

SOUZA, Cláudio Leite. ESTUDO DAS ROTAS DE FORMAÇÃO , TRANSPORTE E CONSUMO DOS GASES METANO E SULFETO DE HIDROGÊNIO. 2010.

SPERLING, Marcos Von; LEMOS CHERNICHARO, Carl Augusto De. Biological Wastewater Treatment in Warm Climate Regions. IWA Publishing, p. 1-856, 2005. Disponível em: <http://choicereviews.org/review/10.5860/CHOICE.45-2633>.

SPIEGEL, R. J.; PRESTON, J. L. Technical assessment of fuel cell operation on anaerobic digester gas at the Yonkers, NY, wastewater treatment plant. Waste Management, v. 23, n. 8, p. 709-717, 2003.

STAZI, Valentina; TOMEI, Maria Concetta. Enhancing anaerobic treatment of domestic wastewater: State of art, innovative technologies and future perspectives. . [S.1: s.n.]. , 2018

TANG, Jiawei et al. Municipal wastewater treatment plants coupled with electrochemical, biological and bio-electrochemical technologies: Opportunities and challenge toward energy self-sufficiency. Journal of Environmental Management, v. 234, n. December 2018, p. 396403, 2019.

TSUTIYA, Milton; HIRATA, Angélica. Aproveitamento e disposição final de lodos de estações de tratamento de água no Estado de São Paulo. 2001, [S.1: s.n.], 2001. p. 1-9.

UN WATER. Wastewater Management - A UN-Water Analytical Brief. . [S.1: s.n.], 2015.

UNESCO. Managing Water under Uncertainty and Risk. . Paris: [s.n.], 2012.

UNFCCC. Project SClean Development Mechanism (CDM). Disponível em: $<$ https://cdm.unfccc.int/Projects/projsearch.html $>$.

UNIÃO EUROPEIA. Directiva 2008/98/CE. Jornal Oficial da União Europeia, L 312, p. 3$30,2008$.

VILLANO, Marianna et al. Carbon and nitrogen removal and enhanced methane production in a microbial electrolysis cell. Bioresource Technology, v. 130, p. 366-371, 2013. Disponível em: <http://dx.doi.org/10.1016/j.biortech.2012.11.080>.

VON SPERLING, MARCOS; CHERNICARO, Carlos Augusto Lemos. Biological 
Wastewater Treatment in Warm Climate Regions. [S.1: s.n.], 2005.

VON SPERLING, Marcos. Princípios do Tratamento Biológico de Águas Residuárias Introdução à qualidade das águas e ao tratamento de esgotos. 3. ed. [S.1: s.n.], 1996. Disponível

em: $<$ https://books.google.com.br/books/about/Introdução_à_qualidade_das_águas_e_a.html?id=1 pxhLVxVFHoC\&printsec $=$ frontcover\&source $=\mathrm{kp} \_$read_button\&redir_esc $=\mathrm{y} \# \mathrm{v}=$ onepage $\& \mathrm{q}=$ dqo $\& \mathrm{f}=$ false $>$.

WANG, Haiman et al. Evaluation of an integrated continuous stirred microbial electrochemical reactor: Wastewater treatment, energy recovery and microbial community. Bioresource Technology, v. 195, p. 89-95, 2015.

WANG, Jie et al. In situ investigation of processing property in combination with integration of microbial fuel cell and tubular membrane bioreactor. Bioresource Technology, v. 149, p. 163-168, 2013. Disponível em: <http://dx.doi.org/10.1016/j.biortech.2013.09.055>.

WANG, Xu et al. Environmental profile of typical anaerobic / anoxic / oxic wastewater treatment systems meeting increasingly stringent treatment standards from a life cycle perspective. Bioresource Technology, v. 126, p. 31-40, 2012.

WANG, Yong-peng et al. A microbial fuel cell - membrane bioreactor integrated system for cost-effective wastewater treatment. Applied Energy, v. 98, p. 230-235, 2012. Disponível em: $<$ http://dx.doi.org/10.1016/j.apenergy.2012.03.029>.

WEI, Chun-hai et al. Sustainable organic loading rate and energy recovery potential of mesophilic anaerobic membrane bioreactor for municipal wastewater treatment. BIORESOURCE TECHNOLOGY, v. 166, p. 326-334, 2014.

WEI, Wei et al. Free ammonia pre-treatment of secondary sludge significantly increases anaerobic methane production. Water Research, v. 118, p. 12-19, 2017.

WORLD BIOENERGY ASSOCIATION - WBA. Energy Recovery from Waste. . [S.1: s.n.], 2017.

XIAO, Li et al. Evaluation of normalized energy recovery (NER) in microbial fuel cells affected by reactor dimensions and substrates. Bioresource Technology, v. 157, p. 77-83, 2014. Disponível em: <http://dx.doi.org/10.1016/j.biortech.2014.01.086>.

YIN, Robert K. Case study reserach: design and methods. Case Study Research: Design and Methods. [S.1: s.n.]. , 2014

ZHANG, Lei et al. Anaerobic treatment of raw domestic wastewater in a UASB-digester at $10^{\circ} \mathrm{C}$ and microbial community dynamics. . [S.1: s.n.]. , 2018

ZHOU, Guowang et al. Assessment of a novel overflow-type electrochemical membrane 
bioreactor ( EMBR ) for wastewater treatment, energy recovery and membrane fouling mitigation. BIORESOURCE TECHNOLOGY, v. 196, p. 648-655, 2015. Disponível em: $<$ http://dx.doi.org/10.1016/j.biortech.2015.08.032>. 


\section{APÊNDICE A}

Artigos da revisão de literatura

Fonte: Elaborado pela própria autora 


\begin{tabular}{|c|c|c|c|c|c|c|c|c|}
\hline Revista & Título do Artigo & Autor(es) & Referências & Palavras Chaves & $\begin{array}{l}\text { País de } \\
\text { Origem }\end{array}$ & Categoria & Subcategoria & Fonte \\
\hline $\begin{array}{l}\text { Applied } \\
\text { Energy }\end{array}$ & $\begin{array}{l}\text { A microbial fuel cell- } \\
\text { membrane bioreactor } \\
\text { integrated system for } \\
\text { cost-effective } \\
\text { wastewater } \\
\text { treatment }\end{array}$ & $\begin{array}{c}\text { Yong-Peng } \\
\text { Wang, Xian-Wei } \\
\text { Liu, Wen-Wei Li, } \\
\text { Feng Li, Yun-Kun } \\
\text { Wang, Guo-Ping } \\
\text { Sheng, Raymond } \\
\text { J. Zeng, Han- } \\
\text { Qing Yu }\end{array}$ & $\begin{array}{l}\text { Volume 98, } \\
2012, \\
\text { Pages 230- } \\
235\end{array}$ & $\begin{array}{l}\text { Microbial fuel cell } \\
\text { (MFC); Membrane } \\
\text { bioreactor (MBR); } \\
\text { Wastewater } \\
\text { treatment; Bio- } \\
\text { cathode; Low-cost }\end{array}$ & China & Tecnologia & $\begin{array}{l}\text { Eficiência no } \\
\text { tratamento }\end{array}$ & $\begin{array}{l}\text { Science } \\
\text { Direct }\end{array}$ \\
\hline $\begin{array}{c}\text { Water } \\
\text { Research }\end{array}$ & $\begin{array}{l}\text { The difference } \\
\text { between energy } \\
\text { consumption and } \\
\text { energy cost: } \\
\text { Modelling energy } \\
\text { tariff structures for } \\
\text { water resource } \\
\text { recovery facilities }\end{array}$ & $\begin{array}{l}\text { I. Aymerich, L. } \\
\text { Rieger, R. } \\
\text { Sobhani, D. } \\
\text { Rosso, LI. } \\
\text { Corominas }\end{array}$ & $\begin{array}{l}\text { Volume 81, } \\
\qquad 2015, \\
\text { Pages 113- } \\
123\end{array}$ & $\begin{array}{c}\text { Wastewater } \\
\text { treatment; Process } \\
\text { control; Energy costs; } \\
\text { Energy tariff; Time-of- } \\
\text { use; Benchmark } \\
\text { Simulation Model } \\
\text { (BSM) }\end{array}$ & Espanha & Gestão & $\begin{array}{l}\text { Modelagem } \\
\text { matemática }\end{array}$ & $\begin{array}{r}\text { Science } \\
\text { Direct }\end{array}$ \\
\hline $\begin{array}{l}\text { Bioresource } \\
\text { Technology }\end{array}$ & $\begin{array}{c}\text { A novel bio- } \\
\text { electrochemical } \\
\text { system with } \\
\text { sand/activated } \\
\text { carbon separator, Al } \\
\text { anode and bio-anode } \\
\text { integrated micro- } \\
\text { electrolysis/electro- } \\
\text { flocculation cost } \\
\text { effectively treated } \\
\text { high load wastewater } \\
\text { with energy recovery }\end{array}$ & $\begin{array}{l}\text { Changfei Gao, } \\
\text { Lifen Liu, Fenglin } \\
\text { Yang }\end{array}$ & $\begin{array}{c}\text { Volume } 249, \\
2018, \\
\text { Pages } 24-34\end{array}$ & $\begin{array}{l}\text { Micro-electrolysis; } \\
\text { Electro-flocculation; } \\
\text { Al anode; Membrane } \\
\text { and bio- } \\
\text { electrochemical } \\
\text { system; Wastewater } \\
\text { treatment }\end{array}$ & China & Tecnologia & $\begin{array}{l}\text { Eficiência no } \\
\text { tratamento }\end{array}$ & $\begin{array}{l}\text { Science } \\
\text { Direct }\end{array}$ \\
\hline $\begin{array}{c}\text { Water } \\
\text { Research }\end{array}$ & $\begin{array}{l}\text { Does carbon } \\
\text { reduction increase } \\
\text { sustainability? A } \\
\text { study in wastewater } \\
\text { treatment }\end{array}$ & $\begin{array}{l}\text { Christine } \\
\text { Sweetapple, } \\
\text { Guangtao Fu, } \\
\text { David Butler }\end{array}$ & $\begin{array}{l}\text { Volume } 87, \\
2015, \\
\text { Pages } 522- \\
530\end{array}$ & $\begin{array}{l}\text { Carbon neutral; } \\
\text { Control; Energy; } \\
\text { Sustainability; WWTP }\end{array}$ & $\begin{array}{l}\text { Reino } \\
\text { Unido }\end{array}$ & Tecnologia & $\begin{array}{l}\text { Eficiência no } \\
\text { tratamento }\end{array}$ & $\begin{array}{l}\text { Science } \\
\text { Direct }\end{array}$ \\
\hline $\begin{array}{l}\text { Science of The } \\
\text { Total } \\
\text { Environment }\end{array}$ & $\begin{array}{l}\text { Modeling assisted } \\
\text { evaluation of direct } \\
\text { electricity generation } \\
\text { from waste heat of } \\
\text { wastewater via a } \\
\text { thermoelectric } \\
\text { generator }\end{array}$ & $\begin{array}{l}\text { Shiqiang Zou, } \\
\text { Eurydice } \\
\text { Kanimba, } \\
\text { Thomas E. Diller, } \\
\text { Zhiting Tian, } \\
\text { Zhen He }\end{array}$ & $\begin{array}{c}\text { Volume 635, } \\
\qquad 2018, \\
\text { Pages 1215- } \\
1224\end{array}$ & $\begin{array}{c}\text { Thermoelectric } \\
\text { generator; Waste } \\
\text { heat; Wastewater; } \\
\text { Energy recovery; } \\
\text { Mathematical } \\
\text { modeling }\end{array}$ & $\begin{array}{l}\text { Estados } \\
\text { Unidos }\end{array}$ & Tecnologia & $\begin{array}{l}\text { Eficiência no } \\
\text { tratamento }\end{array}$ & $\begin{array}{l}\text { Science } \\
\text { Direct }\end{array}$ \\
\hline $\begin{array}{l}\text { Bioresource } \\
\text { Technology }\end{array}$ & $\begin{array}{l}\text { Toward energy- } \\
\text { neutral wastewater } \\
\text { treatment: A high- } \\
\text { rate contact } \\
\text { stabilization process } \\
\text { to maximally recover } \\
\text { sewage organics }\end{array}$ & $\begin{array}{c}\text { Francis A. } \\
\text { Meerburg, Nico } \\
\text { Boon, Tim Van } \\
\text { Winckel, Jensen } \\
\text { A.R. Vercamer, } \\
\text { Ingmar Nopens, } \\
\text { Siegfried E. } \\
\text { Vlaeminck }\end{array}$ & $\begin{array}{l}\text { Volume 179, } \\
\text { 2015, } \\
\text { Pages 373- } \\
381\end{array}$ & $\begin{array}{c}\text { AB-system; Bio- } \\
\text { flocculation; F/M } \\
\text { ratio; Mainstream } \\
\text { partial } \\
\text { nitritation/anammox; } \\
\text { Respirometry }\end{array}$ & Bélgica & Tecnologia & Autossuficiência & $\begin{array}{l}\text { Science } \\
\text { Direct }\end{array}$ \\
\hline
\end{tabular}




\begin{tabular}{|c|c|c|c|c|c|c|c|c|}
\hline Revista & Título do Artigo & Autor(es) & Referências & Palavras Chaves & $\begin{array}{l}\text { País de } \\
\text { Origem }\end{array}$ & Categoria & Subcategoria & Fonte \\
\hline $\begin{array}{l}\text { Bioresource } \\
\text { Technology }\end{array}$ & $\begin{array}{l}\text { Co-management of } \\
\text { domestic wastewater } \\
\text { and food waste: A life } \\
\text { cycle comparison of } \\
\text { alternative food } \\
\text { waste diversion } \\
\text { strategies }\end{array}$ & $\begin{array}{l}\text { Adilson M. } \\
\text { Becker, Kevin Yu, } \\
\text { Lauren B. } \\
\text { Stadler, Adam L. } \\
\quad \text { Smith }\end{array}$ & $\begin{array}{c}\text { Volume 223, } \\
2017, \\
\text { Pages 131- } \\
140\end{array}$ & $\begin{array}{l}\text { Life cycle assessment; } \\
\text { Domestic wastewater; } \\
\qquad \text { Food waste; } \\
\text { Anaerobic membrane } \\
\text { bioreactor; High rate } \\
\text { activated sludge }\end{array}$ & $\begin{array}{l}\text { Estados } \\
\text { Unidos }\end{array}$ & Impacto & $\begin{array}{c}\text { Análise do Ciclo } \\
\text { de Vida }\end{array}$ & $\begin{array}{r}\text { Science } \\
\text { Direct }\end{array}$ \\
\hline $\begin{array}{c}\text { Journal of } \\
\text { Environmental } \\
\text { Management }\end{array}$ & $\begin{array}{l}\text { Municipal wastewater } \\
\text { treatment plants } \\
\text { coupled with } \\
\text { electrochemical, } \\
\text { biological and bio- } \\
\text { electrochemical } \\
\text { technologies: } \\
\text { Opportunities and } \\
\text { challenge toward } \\
\text { energy self- } \\
\text { sufficiency }\end{array}$ & $\begin{array}{l}\text { Jiawei Tang, } \\
\text { Chunhui Zhang, } \\
\text { Xuelu Shi, Jiajun } \\
\text { Sun, Jeffrey A. } \\
\text { Cunningham }\end{array}$ & $\begin{array}{l}\text { Volume 234, } \\
\text { 2019, } \\
\text { Pages 396- } \\
403\end{array}$ & $\begin{array}{c}\text { Wastewater } \\
\text { treatment plants; } \\
\text { Electrochemical } \\
\text { technology; Energy } \\
\text { recovery; Sustainable } \\
\text { wastewater } \\
\text { treatment and reuse; } \\
\text { Carbon abatement }\end{array}$ & China & Tecnologia & Autossuficiência & $\begin{array}{l}\text { Science } \\
\text { Direct }\end{array}$ \\
\hline $\begin{array}{c}\text { Water } \\
\text { Research }\end{array}$ & $\begin{array}{l}\text { Anaerobic treatment } \\
\text { of municipal } \\
\text { wastewater at } \\
\text { ambient } \\
\text { temperature: Analysis } \\
\text { of archaeal } \\
\text { community structure } \\
\text { and recovery of } \\
\text { dissolved methane }\end{array}$ & $\begin{array}{c}\text { Wasala } \\
\text { M.K.R.T.W. } \\
\text { Bandara, } \\
\text { Tomonori } \\
\text { Kindaichi, Hisashi } \\
\text { Satoh, Manabu } \\
\text { Sasakawa, } \\
\text { Yoshihito } \\
\text { Nakahara, } \\
\text { Masahiro } \\
\text { Takahashi, } \\
\text { Satoshi Okabe }\end{array}$ & $\begin{array}{l}\text { Volume } 46 \text {, } \\
\text { Issue } 17, \\
2012, \\
\text { Pages } 5756- \\
5764\end{array}$ & $\begin{array}{l}\text { Archaeal community } \\
\text { structure; Degassing } \\
\text { membrane; Dissolved } \\
\text { methane; Municipal } \\
\text { wastewater; } \\
\text { Psychrophilic } \\
\text { condition; Upflow } \\
\text { anaerobic sludge } \\
\text { blanket process }\end{array}$ & Japão & Tecnologia & $\begin{array}{l}\text { Eficiência na } \\
\text { recuperação } \\
\text { energética }\end{array}$ & $\begin{array}{l}\text { Science } \\
\text { Direct }\end{array}$ \\
\hline $\begin{array}{c}\text { Water } \\
\text { Research }\end{array}$ & $\begin{array}{l}\text { A mathematical } \\
\text { model to predict the } \\
\text { effect of heat } \\
\text { recovery on the } \\
\text { wastewater } \\
\text { temperature in } \\
\text { sewers }\end{array}$ & $\begin{array}{c}\text { David J. } \\
\text { Dürrenmatt, } \\
\text { Oskar Wanner }\end{array}$ & $\begin{array}{l}\text { Volume 48, } \\
\text { 2014, } \\
\text { Pages 548- } \\
558\end{array}$ & $\begin{array}{l}\text { Sewer; Modeling; } \\
\text { Wastewater } \\
\text { temperature; Heat } \\
\text { transfer; Heat } \\
\text { recovery }\end{array}$ & Suíça & Tecnologia & $\begin{array}{l}\text { Eficiência no } \\
\text { tratamento }\end{array}$ & $\begin{array}{r}\text { Science } \\
\text { Direct }\end{array}$ \\
\hline $\begin{array}{c}\text { Water } \\
\text { Research }\end{array}$ & $\begin{array}{l}\text { Integrating microbial } \\
\text { fuel cells with } \\
\text { anaerobic } \\
\text { acidification and } \\
\text { forward osmosis } \\
\text { membrane for } \\
\text { enhancing bio- } \\
\text { electricity and water } \\
\text { recovery from low- } \\
\text { strength wastewater }\end{array}$ & $\begin{array}{l}\text { Jinmeng Liu, } \\
\text { Xinhua Wang, } \\
\text { Zhiwei Wang, } \\
\text { Yuqin Lu, Xiufen } \\
\text { Li, Yueping Ren }\end{array}$ & $\begin{array}{c}\text { Volume } 110, \\
2017, \\
\text { Pages } 74-82\end{array}$ & $\begin{array}{l}\text { Microbial fuel cell; } \\
\text { Forward osmosis } \\
\text { membrane; Anaerobic } \\
\text { acidification; Bio- } \\
\text { electricity production; } \\
\text { Wastewater } \\
\text { treatment }\end{array}$ & China & Tecnologia & $\begin{array}{l}\text { Eficiência no } \\
\text { tratamento }\end{array}$ & $\begin{array}{r}\text { Science } \\
\text { Direct }\end{array}$ \\
\hline $\begin{array}{l}\text { Science of The } \\
\text { Total } \\
\text { Environment }\end{array}$ & $\begin{array}{l}\text { Life cycle assessment } \\
\text { of high rate algal } \\
\text { ponds for wastewater } \\
\text { treatment and } \\
\text { resource recovery }\end{array}$ & $\begin{array}{l}\text { Larissa Terumi } \\
\text { Arashiro, Neus } \\
\text { Montero, Ivet } \\
\text { Ferrer, Francisco } \\
\text { Gabriel Acién, }\end{array}$ & $\begin{array}{c}\text { Volumes } \\
622-623, \\
2018, \\
\text { Pages } 1118- \\
1130\end{array}$ & $\begin{array}{l}\text { Biogas; Environmental } \\
\text { impact assessment; } \\
\text { Fertilizer; Life cycle } \\
\text { assessment; }\end{array}$ & Espanha & Impacto & $\begin{array}{c}\text { Análise do Ciclo } \\
\text { de Vida }\end{array}$ & $\begin{array}{r}\text { Science } \\
\text { Direct }\end{array}$ \\
\hline
\end{tabular}




\begin{tabular}{|c|c|c|c|c|c|c|c|c|}
\hline Revista & Título do Artigo & Autor(es) & Referências & Palavras Chaves & $\begin{array}{l}\text { País de } \\
\text { Origem }\end{array}$ & Categoria & Subcategoria & Fonte \\
\hline & & $\begin{array}{l}\text { Cintia Gómez, } \\
\text { Marianna Garfí }\end{array}$ & & $\begin{array}{c}\text { Microalgae; Resource } \\
\text { recovery }\end{array}$ & & & & \\
\hline $\begin{array}{c}\text { Water } \\
\text { Research }\end{array}$ & $\begin{array}{l}\text { Bioflocculation } \\
\text { management through } \\
\text { high-rate contact- } \\
\text { stabilization: A } \\
\text { promising technology } \\
\text { to recover organic } \\
\text { carbon from low- } \\
\text { strength wastewater }\end{array}$ & $\begin{array}{c}\text { Arifur Rahman, } \\
\text { Francis A. } \\
\text { Meerburg, } \\
\text { Shravani } \\
\text { Ravadagundhi, } \\
\text { Bernhard Wett, } \\
\text { Jose Jimenez, } \\
\text { Charles Bott, } \\
\text { Ahmed Al-Omari, } \\
\text { Rumana Riffat, } \\
\text { Sudhir Murthy, } \\
\text { Haydée De } \\
\text { Clippeleir }\end{array}$ & 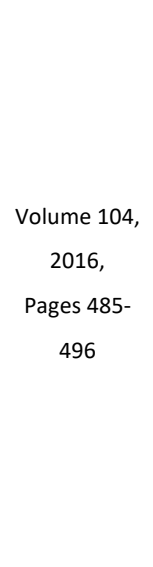 & $\begin{array}{c}\text { Adsorption; Carbon } \\
\text { capture; Energy } \\
\text { neutrality; } \\
\text { Extracellular } \\
\text { polymeric substances; } \\
\text { Observed yield; } \\
\text { Municipal wastewater }\end{array}$ & $\begin{array}{l}\text { Estados } \\
\text { Unidos }\end{array}$ & Tecnologia & $\begin{array}{l}\text { Análises de } \\
\text { tecnologia }\end{array}$ & $\begin{array}{r}\text { Science } \\
\text { Direct }\end{array}$ \\
\hline $\begin{array}{c}\text { Water } \\
\text { Research }\end{array}$ & $\begin{array}{l}\text { Socio-technical } \\
\text { strategies and } \\
\text { behavior change to } \\
\text { increase the adoption } \\
\text { and sustainability of } \\
\text { wastewater resource } \\
\text { recovery systems }\end{array}$ & $\begin{array}{c}\text { Christine Prouty, } \\
\text { Shima Mohebbi, } \\
\text { Qiong Zhang }\end{array}$ & $\begin{array}{c}\text { Volume 137, } \\
2018, \\
\text { Pages 107- } \\
119\end{array}$ & $\begin{array}{l}\text { Technology adoption; } \\
\text { Community-informed } \\
\text { modeling; Mixed- } \\
\text { method; Sustainability } \\
\text { measure; Structural } \\
\text { change; System } \\
\text { dynamics }\end{array}$ & $\begin{array}{l}\text { Estados } \\
\text { Unidos }\end{array}$ & Gestão & Análise Social & $\begin{array}{r}\text { Science } \\
\text { Direct }\end{array}$ \\
\hline $\begin{array}{l}\text { Bioresource } \\
\text { Technology }\end{array}$ & $\begin{array}{c}\text { Sustainable organic } \\
\text { loading rate and } \\
\text { energy recovery } \\
\text { potential of } \\
\text { mesophilic anaerobic } \\
\text { membrane bioreactor } \\
\text { for municipal } \\
\text { wastewater } \\
\text { treatment }\end{array}$ & $\begin{array}{l}\text { Chun-Hai Wei, } \\
\text { Moustapha } \\
\text { Harb, Gary Amy, } \\
\text { Pei-Ying Hong, } \\
\text { TorOve Leiknes }\end{array}$ & $\begin{array}{c}\text { Volume 166, } \\
\text { 2014, } \\
\text { Pages 326- } \\
334\end{array}$ & $\begin{array}{c}\text { Anaerobic membrane } \\
\text { bioreactor; Municipal } \\
\text { wastewater; } \\
\text { Sustainable organic } \\
\text { loading rate; Methane } \\
\text { production; } \\
\text { Sustainable flux }\end{array}$ & $\begin{array}{l}\text { Arábia } \\
\text { Saudita }\end{array}$ & Tecnologia & $\begin{array}{c}\text { Eficiência na } \\
\text { recuperação } \\
\text { energética }\end{array}$ & $\begin{array}{r}\text { Science } \\
\text { Direct }\end{array}$ \\
\hline $\begin{array}{l}\text { Bioresource } \\
\text { Technology }\end{array}$ & $\begin{array}{l}\text { Role of macrophyte } \\
\text { and effect of } \\
\text { supplementary } \\
\text { aeration in up-flow } \\
\text { constructed wetland- } \\
\text { microbial fuel cell for } \\
\text { simultaneous } \\
\text { wastewater } \\
\text { treatment and energy } \\
\text { recovery }\end{array}$ & $\begin{array}{l}\text { Yoong-Ling Oon, } \\
\text { Soon-An Ong, Li- } \\
\text { Ngee Ho, Yee- } \\
\text { Shian Wong, } \\
\text { Farrah Aini } \\
\text { Dahalan, Yoong- } \\
\text { Sin Oon, } \\
\text { Harvinder Kaur } \\
\text { Lehl, Wei-Eng } \\
\text { Thung, Noradiba } \\
\text { Nordin }\end{array}$ & $\begin{array}{l}\text { Volume 224, } \\
\text { 2017, } \\
\text { Pages 265- } \\
275\end{array}$ & $\begin{array}{l}\text { Up-flow constructed } \\
\text { wetland-microbial } \\
\text { fuel cell; Biological } \\
\text { wastewater } \\
\text { treatment; Aeration; } \\
\text { Bioelectricity } \\
\text { recovery; Normalized } \\
\text { energy recovery }\end{array}$ & Malásia & Tecnologia & $\begin{array}{l}\text { Análises de } \\
\text { tecnologia }\end{array}$ & $\begin{array}{r}\text { Science } \\
\text { Direct }\end{array}$ \\
\hline $\begin{array}{l}\text { Bioresource } \\
\text { Technology }\end{array}$ & $\begin{array}{c}\text { Effects of anode } \\
\text { spacing and flow rate } \\
\text { on energy recovery of } \\
\text { flat-panel air-cathode } \\
\text { microbial fuel cells } \\
\text { using domestic } \\
\text { wastewater }\end{array}$ & $\begin{array}{c}\text { Younghyun Park, } \\
\text { Van Khanh } \\
\text { Nguyen, } \\
\text { Seonghwan Park, } \\
\text { Jaecheul Yu, } \\
\text { Taeho Lee }\end{array}$ & $\begin{array}{c}\text { Volume 258, } \\
\text { 2018, } \\
\text { Pages 57-63 }\end{array}$ & $\begin{array}{c}\text { FA-MFC; Normalized } \\
\text { energy recovery; } \\
\text { Domestic wastewater; } \\
\text { Anode spacing; Flow } \\
\text { rate }\end{array}$ & $\begin{array}{l}\text { República } \\
\text { da Coreia }\end{array}$ & Tecnologia & $\begin{array}{c}\text { Eficiência na } \\
\text { recuperação } \\
\text { energética }\end{array}$ & $\begin{array}{r}\text { Science } \\
\text { Direct }\end{array}$ \\
\hline
\end{tabular}




\begin{tabular}{|c|c|c|c|c|c|c|c|c|}
\hline Revista & Título do Artigo & Autor(es) & Referências & Palavras Chaves & $\begin{array}{l}\text { País de } \\
\text { Origem }\end{array}$ & Categoria & Subcategoria & Fonte \\
\hline $\begin{array}{l}\text { Bioresource } \\
\text { Technology }\end{array}$ & $\begin{array}{c}\text { Psychrophilic } \\
\text { anaerobic dynamic } \\
\text { membrane bioreactor } \\
\text { for domestic } \\
\text { wastewater } \\
\text { treatment: Effects of } \\
\text { organic loading and } \\
\text { sludge recycling }\end{array}$ & $\begin{array}{l}\text { Yisong Hu, Yuan } \\
\text { Yang, Shichun } \\
\text { Yu, Xiaochang C. } \\
\text { Wang, Jialing } \\
\text { Tang }\end{array}$ & $\begin{array}{c}\text { Volume } 270, \\
2018, \\
\text { Pages } 62-69\end{array}$ & $\begin{array}{c}\text { Psychrophilic } \\
\text { anaerobic dynamic } \\
\text { membrane } \\
\text { bioreactor; } \\
\text { Wastewater } \\
\text { treatment; Organic } \\
\text { loading; Biogas } \\
\text { production; } \\
\text { Membrane fouling }\end{array}$ & China & Tecnologia & $\begin{array}{l}\text { Análises de } \\
\text { tecnologia }\end{array}$ & $\begin{array}{l}\text { Science } \\
\text { Direct }\end{array}$ \\
\hline $\begin{array}{l}\text { Bioresource } \\
\text { Technology }\end{array}$ & $\begin{array}{c}\text { Effectiveness of } \\
\text { domestic wastewater } \\
\text { treatment using } \\
\text { microbial fuel cells at } \\
\text { ambient and } \\
\text { mesophilic } \\
\text { temperatures }\end{array}$ & $\begin{array}{l}\text { Youngho Ahn, } \\
\text { Bruce E. Logan }\end{array}$ & $\begin{array}{l}\text { Volume } 101, \\
\text { Issue 2, } \\
2010, \\
\text { Pages 469- } \\
475\end{array}$ & $\begin{array}{l}\text { Domestic wastewater } \\
\text { treatment; Energy } \\
\text { recovery; Microbial } \\
\text { fuel cells (MFCs); } \\
\text { Power generation; } \\
\text { Temperature effect }\end{array}$ & $\begin{array}{l}\text { República } \\
\text { da Coreia }\end{array}$ & Tecnologia & $\begin{array}{l}\text { Eficiência no } \\
\text { tratamento }\end{array}$ & $\begin{array}{r}\text { Science } \\
\text { Direct }\end{array}$ \\
\hline $\begin{array}{c}\text { Journal of } \\
\text { Environmental } \\
\text { Management }\end{array}$ & $\begin{array}{l}\text { Energy footprint and } \\
\text { carbon emission } \\
\text { reduction using off- } \\
\text { the-grid solar- } \\
\text { powered mixing for } \\
\text { lagoon treatment }\end{array}$ & $\begin{array}{c}\text { Yuyuan Jiang, } \\
\text { Brian Bebee, } \\
\text { Alvaro Mendoza, } \\
\text { Alice K. } \\
\text { Robinson, } \\
\text { Xiaying Zhang, } \\
\text { Diego Rosso }\end{array}$ & $\begin{array}{c}\text { Volume 205, } \\
2018, \\
\text { Pages 125- } \\
133\end{array}$ & $\begin{array}{l}\text { Lagoon; Energy; } \\
\text { Carbon footprint; } \\
\text { Wastewater; Mixing; } \\
\text { Solar power }\end{array}$ & $\begin{array}{l}\text { Estados } \\
\text { Unidos }\end{array}$ & Impacto & $\begin{array}{c}\text { Gases do Efeito } \\
\text { Estufa }\end{array}$ & $\begin{array}{l}\text { Science } \\
\text { Direct }\end{array}$ \\
\hline $\begin{array}{l}\text { Bioresource } \\
\text { Technology }\end{array}$ & $\begin{array}{l}\text { Sewage treatment by } \\
\text { an UAFB-EGSB } \\
\text { biosystem with } \\
\text { energy recovery and } \\
\text { autotrophic nitrogen } \\
\text { removal under } \\
\text { different } \\
\text { temperatures }\end{array}$ & $\begin{array}{c}\text { Da-Wen Gao, } \\
\text { Xiao-Li Huang, Yu } \\
\text { Tao, Yan Cong, } \\
\text { Xiao-long Wang }\end{array}$ & $\begin{array}{c}\text { Volume 181, } \\
\text { 2015, } \\
\text { Pages 26-31 }\end{array}$ & $\begin{array}{c}\text { Domestic wastewater; } \\
\text { AOB-AnAOB granule; } \\
\text { Temperature; } \\
\text { Nitrogen removal; } \\
\text { Resource recovery }\end{array}$ & China & Tecnologia & $\begin{array}{l}\text { Análises de } \\
\text { tecnologia }\end{array}$ & $\begin{array}{l}\text { Science } \\
\text { Direct }\end{array}$ \\
\hline $\begin{array}{l}\text { Bioresource } \\
\text { Technology }\end{array}$ & $\begin{array}{l}\text { Evaluation of an } \\
\text { integrated continuous } \\
\text { stirred microbial } \\
\text { electrochemical } \\
\text { reactor: Wastewater } \\
\text { treatment, energy } \\
\text { recovery and } \\
\text { microbial community }\end{array}$ & $\begin{array}{l}\text { Haiman Wang, } \\
\text { Youpeng Qu, Da } \\
\text { Li, Xiangtong } \\
\text { Zhou, Yujie Feng }\end{array}$ & $\begin{array}{c}\text { Volume 195, } \\
\text { 2015, } \\
\text { Pages 89-95 }\end{array}$ & $\begin{array}{c}\text { Continuous stirred } \\
\text { microbial } \\
\text { electrochemical } \\
\text { reactor (CSMER); } \\
\text { Continuous stirred } \\
\text { tank reactor (CSTR); } \\
\text { COD removal; Energy } \\
\text { recovery; Community } \\
\text { analysis }\end{array}$ & China & Tecnologia & $\begin{array}{l}\text { Análises de } \\
\text { tecnologia }\end{array}$ & $\begin{array}{r}\text { Science } \\
\text { Direct }\end{array}$ \\
\hline $\begin{array}{c}\text { Journal of } \\
\text { Environmental } \\
\text { Management }\end{array}$ & $\begin{array}{l}\text { Costs and benefits of } \\
\text { biogas recovery from } \\
\text { communal anaerobic } \\
\text { digesters treating } \\
\text { domestic wastewater: } \\
\text { Evidence from peri- } \\
\text { urban Zambia }\end{array}$ & $\begin{array}{l}\text { Jeannette } \\
\text { Laramee, } \\
\text { Sebastien } \\
\text { Tilmans, Jennifer } \\
\text { Davis }\end{array}$ & $\begin{array}{c}\text { Volume 210, } \\
\text { 2018, } \\
\text { Pages 23-35 }\end{array}$ & $\begin{array}{c}\text { Biogas; Sanitation; } \\
\text { Energy recovery; } \\
\text { Greenhouse gas } \\
\text { emissions; Zambia; } \\
\text { Africa }\end{array}$ & $\begin{array}{l}\text { Estados } \\
\text { Unidos }\end{array}$ & Tecnologia & $\begin{array}{c}\text { Eficiência na } \\
\text { recuperação } \\
\text { energética }\end{array}$ & $\begin{array}{r}\text { Science } \\
\text { Direct }\end{array}$ \\
\hline
\end{tabular}




\begin{tabular}{|c|c|c|c|c|c|c|c|c|}
\hline Revista & Título do Artigo & Autor(es) & Referências & Palavras Chaves & $\begin{array}{l}\text { País de } \\
\text { Origem }\end{array}$ & Categoria & Subcategoria & Fonte \\
\hline $\begin{array}{c}\text { Journal of } \\
\text { Environmental } \\
\text { Management }\end{array}$ & $\begin{array}{l}\text { A novel prototype of } \\
\text { integrated anaerobic } \\
\text { filter-condenser } \\
\text { (ANCO) system for } \\
\text { application of waste } \\
\text { heat from office } \\
\text { building to improve } \\
\text { performances of both } \\
\text { air conditioner and } \\
\text { wastewater } \\
\text { treatment system }\end{array}$ & $\begin{array}{l}\text { Chalearn Bouted, } \\
\text { Chavalit } \\
\text { Ratanatamskul }\end{array}$ & $\begin{array}{c}\text { Volume 231, } \\
2019, \\
\text { Pages 66-72 }\end{array}$ & $\begin{array}{c}\text { Anaerobic filter- } \\
\text { condenser (ANCO); } \\
\text { Wastewater } \\
\text { treatment } \\
\text { performance; Waste } \\
\text { heat recovery; COP } \\
\text { improvement; Green } \\
\text { office building model }\end{array}$ & Tailândia & Tecnologia & $\begin{array}{l}\text { Análises de } \\
\text { tecnologia }\end{array}$ & $\begin{array}{r}\text { Science } \\
\text { Direct }\end{array}$ \\
\hline $\begin{array}{l}\text { Applied } \\
\text { Energy }\end{array}$ & $\begin{array}{l}\text { The feasibility and } \\
\text { challenges of energy } \\
\text { self-sufficient } \\
\text { wastewater } \\
\text { treatment plants }\end{array}$ & $\begin{array}{l}\text { Yifan Gu, Yue Li, } \\
\text { Xuyao Li, } \\
\text { Pengzhou Luo, } \\
\text { Hongtao Wang, } \\
\text { Zoe P. Robinson, } \\
\text { Xin Wang, Jiang } \\
\text { Wu, Fengting Li }\end{array}$ & $\begin{array}{c}\text { Volume } 204, \\
2017, \\
\text { Pages } 1463- \\
1475\end{array}$ & $\begin{array}{c}\text { Wastewater } \\
\text { treatment plants; } \\
\text { Energy consumption; } \\
\text { Energy recovery; } \\
\text { Energy self-sufficiency }\end{array}$ & China & Gestão & Análise integrada & $\begin{array}{l}\text { Science } \\
\text { Direct }\end{array}$ \\
\hline $\begin{array}{c}\text { Water } \\
\text { Research }\end{array}$ & $\begin{array}{l}\text { Effects of soluble and } \\
\text { particulate substrate } \\
\text { on the carbon and } \\
\text { energy footprint of } \\
\quad \text { wastewater } \\
\text { treatment processes }\end{array}$ & $\begin{array}{l}\text { Riccardo Gori, } \\
\text { Lu-Man Jiang, } \\
\text { Reza Sobhani, } \\
\text { Diego Rosso }\end{array}$ & $\begin{array}{l}\text { Volume } 45, \\
\text { Issue } 18, \\
2011, \\
\text { Pages } 5858 \text { - } \\
5872\end{array}$ & $\begin{array}{l}\text { COD fractionation; } \\
\text { Soluble COD; } \\
\text { Hydrolysis; Carbon } \\
\text { footprint; Energy } \\
\text { footprint; Wastewater } \\
\text { treatment }\end{array}$ & Itália & Impacto & $\begin{array}{c}\text { Gases do Efeito } \\
\text { Estufa }\end{array}$ & $\begin{array}{r}\text { Science } \\
\text { Direct }\end{array}$ \\
\hline $\begin{array}{c}\text { Journal of } \\
\text { Environmental } \\
\text { Management }\end{array}$ & $\begin{array}{l}\text { Pilot-scale evaluation } \\
\text { of semi-passive } \\
\text { treatment } \\
\text { technologies for the } \\
\text { treatment of septage } \\
\text { under temperate } \\
\text { climate conditions }\end{array}$ & $\begin{array}{c}\text { Christine Gan, } \\
\text { Pascale } \\
\text { Champagne, } \\
\text { Geof Hall }\end{array}$ & $\begin{array}{c}\text { Volume } 216, \\
2018, \\
\text { Pages } 357- \\
371\end{array}$ & $\begin{array}{c}\text { Biofilm; Wastewater } \\
\text { treatment; Nutrient } \\
\text { removal; } \\
\text { Sustainability; } \\
\text { Septage; Wastewater } \\
\text { stabilization ponds }\end{array}$ & Canada & Tecnologia & $\begin{array}{l}\text { Análises de } \\
\text { tecnologia }\end{array}$ & $\begin{array}{r}\text { Science } \\
\text { Direct }\end{array}$ \\
\hline $\begin{array}{l}\text { Science of The } \\
\text { Total } \\
\text { Environment }\end{array}$ & $\begin{array}{c}\text { An anaerobic } \\
\text { membrane bioreactor } \\
\text { - membrane } \\
\text { distillation hybrid } \\
\text { system for energy } \\
\text { recovery and water } \\
\text { reuse: Removal } \\
\text { performance of } \\
\text { organic carbon, } \\
\text { nutrients, and trace } \\
\text { organic contaminants }\end{array}$ & $\begin{array}{l}\text { Xiaoye Song, } \\
\text { Wenhai Luo, } \\
\text { James } \\
\text { McDonald, } \\
\text { Stuart J. Khan, } \\
\text { Faisal I. Hai, } \\
\text { William E. Price, } \\
\text { Long D. Nghiem }\end{array}$ & $\begin{array}{l}\text { Volumes } \\
628-629 \\
2018 \\
\text { Pages } 358- \\
365\end{array}$ & $\begin{array}{l}\text { Anaerobic membrane } \\
\text { bioreactor (AnMBR); } \\
\text { Membrane distillation } \\
\text { (MD); Trace organic } \\
\text { contaminants (TrOCs); } \\
\text { Energy recovery; } \\
\text { Wastewater } \\
\text { treatment and reuse }\end{array}$ & Austrália & Tecnologia & $\begin{array}{l}\text { Análises de } \\
\text { tecnologia }\end{array}$ & $\begin{array}{r}\text { Science } \\
\text { Direct }\end{array}$ \\
\hline $\begin{array}{c}\text { Water } \\
\text { Research }\end{array}$ & $\begin{array}{l}\text { One-year operation } \\
\text { of } 1000-\mathrm{L} \\
\text { modularized } \\
\text { microbial fuel cell for } \\
\text { municipal wastewater } \\
\text { treatment }\end{array}$ & $\begin{array}{l}\text { Peng Liang, Rui } \\
\text { Duan, Yong } \\
\text { Jiang, Xiaoyuan } \\
\text { Zhang, Yong Qiu, } \\
\text { Xia Huang }\end{array}$ & $\begin{array}{c}\text { Volume 141, } \\
\text { 2018, } \\
\text { Pages 1-8 }\end{array}$ & $\begin{array}{l}\text { Microbial fuel cell; } \\
\qquad \text { Municipal } \\
\text { wastewater; Long- } \\
\text { term operation; } \\
\text { Stacked modules; } \\
\text { Power generation }\end{array}$ & China & Tecnologia & $\begin{array}{l}\text { Análises de } \\
\text { tecnologia }\end{array}$ & $\begin{array}{r}\text { Science } \\
\text { Direct }\end{array}$ \\
\hline
\end{tabular}




\begin{tabular}{|c|c|c|c|c|c|c|c|c|}
\hline Revista & Título do Artigo & Autor(es) & Referências & Palavras Chaves & $\begin{array}{l}\text { País de } \\
\text { Origem }\end{array}$ & Categoria & Subcategoria & Fonte \\
\hline $\begin{array}{l}\text { Bioresource } \\
\text { Technology }\end{array}$ & $\begin{array}{c}\text { Net energy } \\
\text { production and } \\
\text { emissions mitigation } \\
\text { of domestic } \\
\text { wastewater } \\
\text { treatment system: A } \\
\text { comparison of } \\
\text { different biogas- } \\
\text { sludge use } \\
\text { alternatives }\end{array}$ & $\begin{array}{c}\text { Shaoqing Chen, } \\
\text { Bin Chen }\end{array}$ & $\begin{array}{l}\text { Volume 144, } \\
2013 \text {, } \\
\text { Pages 296- } \\
303\end{array}$ & $\begin{array}{l}\text { Net energy } \\
\text { production; Emissions } \\
\text { mitigation; Biogas- } \\
\text { sludge reuse; } \\
\text { Wastewater } \\
\text { treatment; Life cycle } \\
\text { assessment }\end{array}$ & China & Impacto & $\begin{array}{c}\text { Gases do Efeito } \\
\text { Estufa }\end{array}$ & $\begin{array}{l}\text { Science } \\
\text { Direct }\end{array}$ \\
\hline $\begin{array}{c}\text { Journal of } \\
\text { Environmental } \\
\text { Management }\end{array}$ & $\begin{array}{l}\text { Sewage sludge } \\
\text { processing and } \\
\text { management in small } \\
\text { and medium-sized } \\
\text { municipal wastewater } \\
\text { treatment plant-new } \\
\text { technical solution }\end{array}$ & $\begin{array}{l}\text { Anna Grobelak, } \\
\text { Anna Grosser, } \\
\text { Małgorzata } \\
\text { Kacprzak, } \\
\text { Tomasz Kamizela }\end{array}$ & $\begin{array}{c}\text { Volume } 234 \\
2019 \\
\text { Pages } 90-96\end{array}$ & $\begin{array}{c}\text { Sewage sludge } \\
\text { disposal; Small } \\
\text { wastewater } \\
\text { treatment plants; } \\
\text { Compost; Biomass; } \\
\text { Renewable energy }\end{array}$ & Polônia & Gestão & $\begin{array}{l}\text { Gestão de } \\
\text { resíduos }\end{array}$ & $\begin{array}{l}\text { Science } \\
\text { Direct }\end{array}$ \\
\hline $\begin{array}{l}\text { Bioresource } \\
\text { Technology }\end{array}$ & $\begin{array}{l}\text { Effects of light-dark } \\
\text { cycles on } \\
\text { photosynthetic } \\
\text { bacteria wastewater } \\
\text { treatment and } \\
\text { valuable substances } \\
\text { production }\end{array}$ & $\begin{array}{c}\text { Ran Zhi, Anqi } \\
\text { Yang, } \\
\text { Guangming } \\
\text { Zhang, Yichun } \\
\text { Zhu, Fan Meng, } \\
\text { Xueyan Li }\end{array}$ & $\begin{array}{l}\text { Volume 274, } \\
2019, \\
\text { Pages 496- } \\
501\end{array}$ & $\begin{array}{l}\text { Light-dark cycles; PSB } \\
\quad \text { wastewater } \\
\text { treatment; Biomass; } \\
\text { Valuable substances }\end{array}$ & China & Tecnologia & $\begin{array}{l}\text { Eficiência no } \\
\text { tratamento }\end{array}$ & $\begin{array}{l}\text { Science } \\
\text { Direct }\end{array}$ \\
\hline $\begin{array}{l}\text { Bioresource } \\
\text { Technology }\end{array}$ & $\begin{array}{l}\text { An integrated } 45 \mathrm{~L} \\
\text { pilot microbial fuel } \\
\text { cell system at a full- } \\
\text { scale wastewater } \\
\text { treatment plant }\end{array}$ & $\begin{array}{c}\text { Heinz } \\
\text { Hiegemann, } \\
\text { Daniel Herzer, } \\
\text { Edith Nettmann, } \\
\text { Manfred Lübken, } \\
\text { Patrick Schulte, } \\
\text { Karl-Georg } \\
\text { Schmelz, Sylvia } \\
\text { Gredigk- } \\
\text { Hoffmann, Marc } \\
\text { Wichern }\end{array}$ & $\begin{array}{l}\text { Volume 218, } \\
2016, \\
\text { Pages 115- } \\
122\end{array}$ & $\begin{array}{l}\text { Microbial fuel cell; } \\
\text { Upscaling; } \\
\text { Wastewater } \\
\text { treatment plant; } \\
\text { Energy balance }\end{array}$ & Alemanha & Tecnologia & $\begin{array}{l}\text { Análises de } \\
\text { tecnologia }\end{array}$ & $\begin{array}{c}\text { Science } \\
\text { Direct }\end{array}$ \\
\hline $\begin{array}{l}\text { Bioresource } \\
\text { Technology }\end{array}$ & $\begin{array}{c}\text { Energy and } \\
\text { greenhouse gas life } \\
\text { cycle assessment and } \\
\text { cost analysis of } \\
\text { aerobic and } \\
\text { anaerobic membrane } \\
\text { bioreactor systems: } \\
\text { Influence of scale, } \\
\text { population density, } \\
\text { climate, and methane } \\
\text { recovery }\end{array}$ & $\begin{array}{l}\text { Sarah Cashman, } \\
\text { Xin Ma, Janet } \\
\text { Mosley, Jay } \\
\text { Garland, Brian } \\
\text { Crone, Xiaobo } \\
\text { Xue }\end{array}$ & $\begin{array}{c}\text { Volume 254, } \\
\text { 2018, } \\
\text { Pages 56-66 }\end{array}$ & $\begin{array}{l}\text { Life cycle assessment; } \\
\text { Membrane } \\
\text { bioreactor; Energy } \\
\text { demand; Greenhouse } \\
\text { gas; Life cycle cost }\end{array}$ & $\begin{array}{l}\text { Estados } \\
\text { Unidos }\end{array}$ & Impacto & $\begin{array}{c}\text { Análise do Ciclo } \\
\text { de Vida }\end{array}$ & $\begin{array}{c}\text { Science } \\
\text { Direct }\end{array}$ \\
\hline $\begin{array}{l}\text { Applied } \\
\text { Energy }\end{array}$ & $\begin{array}{l}\text { High-rate } \\
\text { thermophilic bio- } \\
\text { methanation of the } \\
\text { fine sieved fraction } \\
\text { from Dutch municipal } \\
\text { raw sewage: Cost- }\end{array}$ & $\begin{array}{c}\text { Dara S.M. } \\
\text { Ghasimi, Merle } \\
\text { de Kreuk, Sung } \\
\text { Kyu Maeng, } \\
\text { Marcel H. }\end{array}$ & $\begin{array}{c}\text { Volume 165, } \\
\text { 2016, } \\
\text { Pages 569- } \\
582\end{array}$ & $\begin{array}{l}\text { Anaerobic digestion; } \\
\text { Mesophilic, } \\
\text { thermophilic; BMP; } \\
\text { CHP, energy recovery }\end{array}$ & $\begin{array}{l}\text { Países } \\
\text { Baixos }\end{array}$ & Tecnologia & $\begin{array}{c}\text { Eficiência na } \\
\text { recuperação } \\
\text { energética }\end{array}$ & $\begin{array}{c}\text { Science } \\
\text { Direct }\end{array}$ \\
\hline
\end{tabular}




\begin{tabular}{|c|c|c|c|c|c|c|c|c|}
\hline \multirow[t]{2}{*}{ Revista } & Título do Artigo & Autor(es) & Referências & Palavras Chaves & $\begin{array}{l}\text { País de } \\
\text { Origem }\end{array}$ & Categoria & Subcategoria & Fonte \\
\hline & $\begin{array}{l}\text { effective potentials } \\
\text { for on-site energy } \\
\text { recovery }\end{array}$ & $\begin{array}{l}\text { Zandvoort, Jules } \\
\text { B. van Lier }\end{array}$ & & & & & & \\
\hline $\begin{array}{c}\text { Water } \\
\text { Research }\end{array}$ & $\begin{array}{l}\text { Microalgae recycling } \\
\text { improves biomass } \\
\text { recovery from } \\
\text { wastewater } \\
\text { treatment high rate } \\
\text { algal ponds }\end{array}$ & $\begin{array}{c}\text { Raquel } \\
\text { Gutiérrez, Ivet } \\
\text { Ferrer, Andrés } \\
\text { González- } \\
\text { Molina, Humbert } \\
\text { Salvadó, Joan } \\
\text { García, Enrica } \\
\text { Ugge }\end{array}$ & $\begin{array}{l}\text { Volume 106, } \\
\text { 2016, } \\
\text { Pages 539- } \\
549\end{array}$ & $\begin{array}{c}\text { Bioflocculation; } \\
\text { Biomass recovery; } \\
\text { Microalgae species } \\
\text { selection; Microalgal } \\
\text { biomass production; } \\
\text { Harvesting }\end{array}$ & Espanha & Tecnologia & $\begin{array}{l}\text { Análises de } \\
\text { tecnologia }\end{array}$ & $\begin{array}{l}\text { Science } \\
\text { Direct }\end{array}$ \\
\hline $\begin{array}{l}\text { Bioresource } \\
\text { Technology }\end{array}$ & $\begin{array}{c}\text { Perspectives on } \\
\text { anaerobic membrane } \\
\text { bioreactor treatment } \\
\text { of domestic } \\
\text { wastewater: A critical } \\
\text { review }\end{array}$ & $\begin{array}{l}\text { Adam L. Smith, } \\
\text { Lauren B. } \\
\text { Stadler, Nancy G. } \\
\text { Love, Steven J. } \\
\text { Skerlos, Lutgarde } \\
\text { Raskin }\end{array}$ & $\begin{array}{c}\text { Volume 122, } \\
2012, \\
\text { Pages 149- } \\
159\end{array}$ & $\begin{array}{l}\text { Anaerobic membrane } \\
\text { bioreactor; Domestic } \\
\text { wastewater; } \\
\text { Membrane fouling; } \\
\text { Psychrophilic; } \\
\text { Dissolved methane }\end{array}$ & $\begin{array}{l}\text { Estados } \\
\text { Unidos }\end{array}$ & Tecnologia & $\begin{array}{l}\text { Eficiência no } \\
\text { tratamento }\end{array}$ & $\begin{array}{l}\text { Science } \\
\text { Direct }\end{array}$ \\
\hline $\begin{array}{l}\text { Science of The } \\
\text { Total } \\
\text { Environment }\end{array}$ & $\begin{array}{l}\text { Feasibility analysis of } \\
\text { wastewater and solid } \\
\text { waste systems for } \\
\text { application in } \\
\text { Indonesia }\end{array}$ & $\begin{array}{l}\text { S.M. Kerstens, I. } \\
\text { Leusbrock, G. } \\
\text { Zeeman }\end{array}$ & $\begin{array}{c}\text { Volumes } \\
\text { 530-531, } \\
\text { 2015, } \\
\text { Pages 53-65 }\end{array}$ & $\begin{array}{c}\text { Wastewater; Solid } \\
\text { waste; Financial } \\
\text { analysis; Technical } \\
\text { analysis; Developing } \\
\text { countries; Resource } \\
\text { recovery }\end{array}$ & $\begin{array}{l}\text { Países } \\
\text { Baixos }\end{array}$ & Gestão & Análise integrada & $\begin{array}{l}\text { Science } \\
\text { Direct }\end{array}$ \\
\hline $\begin{array}{c}\text { Water } \\
\text { Research }\end{array}$ & $\begin{array}{c}\text { Energy recovery } \\
\text { during advanced } \\
\text { wastewater } \\
\text { treatment: } \\
\text { Simultaneous } \\
\text { estrogenic activity } \\
\text { removal and } \\
\text { hydrogen production } \\
\text { through solar } \\
\text { photocatalysis }\end{array}$ & $\begin{array}{l}\text { Wenlong Zhang, } \\
\text { Yi Li, Chao Wang, } \\
\text { Peifang Wang, } \\
\text { Qing Wang }\end{array}$ & $\begin{array}{l}\text { Volume } 47 \text {, } \\
\text { Issue } 3 \text {, } \\
2013, \\
\text { Pages } 1480 \text { - } \\
1490\end{array}$ & $\begin{array}{c}\text { Photocatalysis; } \\
\text { Hydrogen production; } \\
\text { Wastewater } \\
\text { reclamation; } \\
\text { Estrogenic activity; } \\
\text { Reactive oxygen } \\
\text { species; Effluent } \\
\text { organic matter }\end{array}$ & China & Tecnologia & $\begin{array}{l}\text { Análises de } \\
\text { tecnologia }\end{array}$ & $\begin{array}{l}\text { Science } \\
\text { Direct }\end{array}$ \\
\hline $\begin{array}{c}\text { Water } \\
\text { Research }\end{array}$ & $\begin{array}{l}\text { Treatment of food } \\
\text { waste recycling } \\
\text { wastewater using } \\
\text { anaerobic ceramic } \\
\text { membrane bioreactor } \\
\text { for biogas production } \\
\text { in mainstream } \\
\text { treatment process of } \\
\text { domestic wastewater }\end{array}$ & $\begin{array}{l}\text { Yeongmi Jeong, } \\
\text { Slawomir W. } \\
\text { Hermanowicz, } \\
\text { Chanhyuk Park }\end{array}$ & $\begin{array}{c}\text { Volume 123, } \\
2017 \\
\text { Pages } 86-95\end{array}$ & $\begin{array}{l}\text { Anaerobic ceramic } \\
\text { membrane } \\
\text { bioreactor; Biogas; } \\
\text { Ceramic membrane; } \\
\text { Food waste recycling } \\
\text { wastewater (FRW); } \\
\text { Polyvinyl alcohol } \\
\text { (PVA)-gel bead }\end{array}$ & $\begin{array}{l}\text { Coreia do } \\
\text { Sul }\end{array}$ & Tecnologia & $\begin{array}{l}\text { Tecnologias } \\
\text { alternativas }\end{array}$ & $\begin{array}{l}\text { Science } \\
\text { Direct }\end{array}$ \\
\hline $\begin{array}{l}\text { Science of The } \\
\text { Total } \\
\text { Environment }\end{array}$ & $\begin{array}{l}\text { Measuring adaptive } \\
\text { capacity of urban } \\
\text { wastewater } \\
\text { infrastructure - } \\
\text { Change impact and } \\
\text { change propagation }\end{array}$ & Marc Spiller & $\begin{array}{l}\text { Volumes } \\
601-602, \\
2017, \\
\text { Pages } 571- \\
579\end{array}$ & $\begin{array}{c}\text { Change propagation; } \\
\text { Change impact; } \\
\text { System; } \\
\text { Transformation; } \\
\text { Wastewater; Indicator }\end{array}$ & Bélgica & Gestão & $\begin{array}{l}\text { Análise de } \\
\text { infraesturuta }\end{array}$ & $\begin{array}{l}\text { Science } \\
\text { Direct }\end{array}$ \\
\hline
\end{tabular}




\begin{tabular}{|c|c|c|c|c|c|c|c|c|}
\hline Revista & Título do Artigo & Autor(es) & Referências & Palavras Chaves & $\begin{array}{l}\text { País de } \\
\text { Origem }\end{array}$ & Categoria & Subcategoria & Fonte \\
\hline $\begin{array}{l}\text { Bioresource } \\
\text { Technology }\end{array}$ & $\begin{array}{l}\text { Environmental profile } \\
\text { of typical } \\
\text { anaerobic/anoxic/oxic } \\
\text { wastewater } \\
\text { treatment systems } \\
\text { meeting increasingly } \\
\text { stringent treatment } \\
\text { standards from a life } \\
\text { cycle perspective }\end{array}$ & $\begin{array}{l}\text { Xu Wang, Junxin } \\
\text { Liu, Nan-Qi Ren, } \\
\text { Zuoshan Duan }\end{array}$ & $\begin{array}{c}\text { Volume 126, } \\
\text { 2012, } \\
\text { Pages 31-40 }\end{array}$ & $\begin{array}{c}\text { Wastewater } \\
\text { treatment plants } \\
\text { (WWTPs); } \\
\text { Anaerobic/anoxic/oxic } \\
\text { process; } \\
\text { Environmental } \\
\text { burden; Resource } \\
\text { recovery; Life cycle } \\
\text { inventory (LCI) }\end{array}$ & China & Impacto & $\begin{array}{c}\text { Análise do Ciclo } \\
\text { de Vida }\end{array}$ & $\begin{array}{r}\text { Science } \\
\text { Direct }\end{array}$ \\
\hline $\begin{array}{c}\text { Water } \\
\text { Research }\end{array}$ & $\begin{array}{l}\text { Domestic wastewater } \\
\text { treatment with } \\
\text { purple phototrophic } \\
\text { bacteria using a novel } \\
\text { continuous photo } \\
\text { anaerobic membrane } \\
\text { bioreactor }\end{array}$ & $\begin{array}{l}\text { Tim Hülsen, } \\
\text { Edward M. } \\
\text { Barry, Yang Lu, } \\
\text { Daniel Puyol, } \\
\text { Jürg Keller, } \\
\text { Damien J. } \\
\text { Batstone }\end{array}$ & $\begin{array}{c}\text { Volume 100, } \\
\text { 2016, } \\
\text { Pages 486- } \\
495\end{array}$ & $\begin{array}{l}\text { Purple phototrophic } \\
\text { bacteria; Domestic } \\
\text { wastewater; COD; } \\
\text { Nutrient recovery }\end{array}$ & Austrália & Tecnologia & $\begin{array}{l}\text { Análises de } \\
\text { tecnologia }\end{array}$ & $\begin{array}{r}\text { Science } \\
\text { Direct }\end{array}$ \\
\hline $\begin{array}{c}\text { Water } \\
\text { Research }\end{array}$ & $\begin{array}{l}\text { Modelling the } \\
\text { potential for multi- } \\
\text { location in-sewer } \\
\text { heat recovery at a city } \\
\text { scale under different } \\
\text { seasonal scenarios }\end{array}$ & $\begin{array}{c}\text { Mohamad } \\
\text { Abdel-Aal, Alma } \\
\text { Schellart, Stefan } \\
\text { Kroll, Mostafa } \\
\text { Mohamed, } \\
\text { Simon Tait }\end{array}$ & $\begin{array}{c}\text { Volume } 145 \text {, } \\
2018, \\
\text { Pages 618- } \\
630\end{array}$ & $\begin{array}{l}\text { Heat recovery; Heat } \\
\text { transfer modelling; } \\
\text { Wastewater } \\
\text { temperature } \\
\text { prediction; Clean } \\
\text { thermal energy }\end{array}$ & $\begin{array}{l}\text { Reino } \\
\text { Unido }\end{array}$ & Gestão & $\begin{array}{l}\text { Modelagem } \\
\text { matemática }\end{array}$ & $\begin{array}{r}\text { Science } \\
\text { Direct }\end{array}$ \\
\hline $\begin{array}{l}\text { Bioresource } \\
\text { Technology }\end{array}$ & $\begin{array}{l}\text { Effects of changes in } \\
\text { temperature on } \\
\text { treatment } \\
\text { performance and } \\
\text { energy recovery at } \\
\text { mainstream } \\
\text { anaerobic ceramic } \\
\text { membrane bioreactor } \\
\text { for food waste } \\
\text { recycling wastewater } \\
\text { treatment }\end{array}$ & $\begin{array}{l}\text { Kyungjin Cho, } \\
\text { Yeongmi Jeong, } \\
\text { Kyu Won Seo, } \\
\text { Seockheon Lee, } \\
\text { Adam L. Smith, } \\
\text { Seung Gu Shin, } \\
\text { Si-Kyung Cho, } \\
\text { Chanhyuk Park }\end{array}$ & $\begin{array}{c}\text { Volume } 256, \\
2018, \\
\text { Pages } 137- \\
144\end{array}$ & $\begin{array}{l}\text { Anaerobic ceramic } \\
\text { membrane } \\
\text { bioreactor; Domestic } \\
\text { wastewater; Food } \\
\text { waste recycling } \\
\text { wastewater; } \\
\text { Psychrophilic; } \\
\text { Microbial community } \\
\text { structure }\end{array}$ & $\begin{array}{c}\text { Coreia do } \\
\text { Sul }\end{array}$ & Tecnologia & $\begin{array}{l}\text { Eficiência no } \\
\text { tratamento }\end{array}$ & $\begin{array}{r}\text { Science } \\
\text { Direct }\end{array}$ \\
\hline $\begin{array}{c}\text { Water } \\
\text { Research }\end{array}$ & $\begin{array}{l}\text { Identifying the } \\
\text { microbial } \\
\text { communities and } \\
\text { operational } \\
\text { conditions for } \\
\text { optimized } \\
\text { wastewater } \\
\text { treatment in } \\
\text { microbial fuel cells }\end{array}$ & $\begin{array}{l}\text { Shun'ichi Ishii, } \\
\text { Shino Suzuki, } \\
\text { Trina M. Norden- } \\
\text { Krichmar, Angela } \\
\text { Wu, Yuko } \\
\text { Yamanaka, } \\
\text { Kenneth H. } \\
\text { Nealson, Orianna } \\
\text { Bretschger }\end{array}$ & $\begin{array}{l}\text { Volume } 47, \\
\text { Issue 19, } \\
2013, \\
\text { Pages } 7120- \\
7130\end{array}$ & $\begin{array}{c}\text { Microbial fuel cell; } \\
\text { Potentiostatic } \\
\text { operation; Anode } \\
\text { biofilm; Microbial } \\
\text { community dynamics; } \\
\text { 16S rRNA clone } \\
\text { analysis }\end{array}$ & $\begin{array}{l}\text { Estados } \\
\text { Unidos }\end{array}$ & Tecnologia & $\begin{array}{l}\text { Eficiência no } \\
\text { tratamento }\end{array}$ & $\begin{array}{r}\text { Science } \\
\text { Direct }\end{array}$ \\
\hline $\begin{array}{l}\text { Bioresource } \\
\text { Technology }\end{array}$ & $\begin{array}{l}\text { Synergistic effect of } \\
\text { up-flow constructed } \\
\text { wetland and } \\
\text { microbial fuel cell for } \\
\text { simultaneous } \\
\text { wastewater } \\
\text { treatment and energy } \\
\text { recovery }\end{array}$ & $\begin{array}{l}\text { Yoong-Ling Oon, } \\
\text { Soon-An Ong, Li- } \\
\text { Ngee Ho, Yee- } \\
\text { Shian Wong, } \\
\text { Farrah Aini } \\
\text { Dahalan, Yoong- } \\
\text { Sin Oon, } \\
\text { Harvinder Kaur } \\
\text { Lehl, Wei-Eng } \\
\text { Thung }\end{array}$ & $\begin{array}{c}\text { Volume 203, } \\
\begin{array}{c}2016, \\
\text { Pages 190- } \\
197\end{array}\end{array}$ & $\begin{array}{l}\text { Up-flow constructed } \\
\text { wetland; Microbial } \\
\text { fuel cell; Membrane- } \\
\text { less; Activated carbon } \\
\text { as electrodes; } \\
\text { Bioelectricity }\end{array}$ & Malásia & Tecnologia & $\begin{array}{l}\text { Eficiência no } \\
\text { tratamento e } \\
\text { recuperação } \\
\text { energética }\end{array}$ & $\begin{array}{r}\text { Science } \\
\text { Direct }\end{array}$ \\
\hline
\end{tabular}




\begin{tabular}{|c|c|c|c|c|c|c|c|c|}
\hline Revista & Título do Artigo & Autor(es) & Referências & Palavras Chaves & $\begin{array}{l}\text { País de } \\
\text { Origem }\end{array}$ & Categoria & Subcategoria & Fonte \\
\hline $\begin{array}{c}\text { Water } \\
\text { Research }\end{array}$ & $\begin{array}{l}\text { Phototrophic bacteria } \\
\text { for nutrient recovery } \\
\text { from domestic } \\
\text { wastewater }\end{array}$ & $\begin{array}{l}\text { Tim Hülsen, } \\
\text { Damien J. } \\
\text { Batstone, Jürg } \\
\text { Keller }\end{array}$ & $\begin{array}{c}\text { Volume 50, } \\
2014, \\
\text { Pages 18-26 }\end{array}$ & $\begin{array}{l}\text { Purple non-sulphur } \\
\text { bacteria; Domestic } \\
\text { wastewater; COD; } \\
\text { Nutrient recovery; } \\
\text { Assimilation }\end{array}$ & Austrália & Tecnologia & $\begin{array}{l}\text { Análises de } \\
\text { tecnologia }\end{array}$ & $\begin{array}{l}\text { Science } \\
\text { Direct }\end{array}$ \\
\hline $\begin{array}{c}\text { Journal of } \\
\text { Environmental } \\
\text { Management }\end{array}$ & $\begin{array}{l}\text { Can municipal } \\
\text { wastewater } \\
\text { treatment systems be } \\
\text { carbon neutral? }\end{array}$ & $\begin{array}{l}\text { Weiwei Mo, } \\
\text { Qiong Zhang }\end{array}$ & $\begin{array}{c}\text { Volume 112, } \\
2012, \\
\text { Pages } 360- \\
367\end{array}$ & $\begin{array}{l}\text { : Municipal sewage } \\
\text { systems; Carbon } \\
\text { neutrality; Onsite } \\
\text { energy generation; } \\
\text { Nutrient recycling; } \\
\text { Water reuse; } \\
\text { Integrated resource } \\
\text { recovery }\end{array}$ & $\begin{array}{l}\text { Estados } \\
\text { Unidos }\end{array}$ & Impacto & $\begin{array}{c}\text { Gases do Efeito } \\
\text { Estufa }\end{array}$ & $\begin{array}{l}\text { Science } \\
\text { Direct }\end{array}$ \\
\hline $\begin{array}{l}\text { Bioresource } \\
\text { Technology }\end{array}$ & $\begin{array}{l}\text { Assessment of a novel } \\
\text { overflow-type } \\
\text { electrochemical } \\
\text { membrane bioreactor } \\
\text { (EMBR) for } \\
\text { wastewater } \\
\text { treatment, energy } \\
\text { recovery and } \\
\text { membrane fouling } \\
\text { mitigation }\end{array}$ & $\begin{array}{l}\text { Guowang Zhou, } \\
\text { Yuhong Zhou, } \\
\text { Guoqiang Zhou, } \\
\text { Lian Lu, Xiankai } \\
\text { Wan, Huixiang } \\
\text { Shi }\end{array}$ & $\begin{array}{c}\text { Volume 196, } \\
2015, \\
\text { Pages 648- } \\
655\end{array}$ & $\begin{array}{l}\text { Microbial fuel cell; } \\
\text { Membrane } \\
\text { bioreactor; } \\
\text { Wastewater } \\
\text { treatment; Energy } \\
\text { recovery; Membrane } \\
\text { fouling mitigation }\end{array}$ & China & Tecnologia & $\begin{array}{l}\text { Eficiência no } \\
\text { tratamento e } \\
\text { recuperação } \\
\text { energética }\end{array}$ & $\begin{array}{l}\text { Science } \\
\text { Direct }\end{array}$ \\
\hline $\begin{array}{l}\text { Bioresource } \\
\text { Technology }\end{array}$ & $\begin{array}{l}\text { Integrating } \\
\text { microalgae tertiary } \\
\text { treatment into } \\
\text { activated sludge } \\
\text { systems for energy } \\
\text { and nutrients } \\
\text { recovery from } \\
\text { wastewater }\end{array}$ & $\begin{array}{l}\text { Dulce Maria } \\
\text { Arias, Maria } \\
\text { Solé-Bundó, } \\
\text { Marianna Garfí, } \\
\text { Ivet Ferrer, Joan } \\
\text { García, Enrica } \\
\text { Uggetti }\end{array}$ & $\begin{array}{c}\text { Volume 247, } \\
\text { 2018, } \\
\text { Pages 513- } \\
519\end{array}$ & $\begin{array}{l}\text { Anaerobic digestion; } \\
\text { Autohydrolysis } \\
\text { pretreatment; } \\
\text { Bioenergy; Biogas; } \\
\text { Centrate; Microalgal } \\
\text { biomass }\end{array}$ & Espanha & Tecnologia & $\begin{array}{c}\text { Eficiência na } \\
\text { recuperação } \\
\text { energética }\end{array}$ & $\begin{array}{r}\text { Science } \\
\text { Direct }\end{array}$ \\
\hline $\begin{array}{l}\text { Applied } \\
\text { Energy }\end{array}$ & $\begin{array}{l}\text { Microbial electrolysis } \\
\text { cells for hydrogen } \\
\text { production and urban } \\
\text { wastewater } \\
\text { treatment: A case } \\
\text { study of Saudi Arabia }\end{array}$ & $\begin{array}{l}\text { M.Z. Khan, A.S. } \\
\text { Nizami, M. } \\
\text { Rehan, O.K.M. } \\
\text { Ouda, S. Sultana, } \\
\text { I.M. Ismail, K. } \\
\text { Shahzad }\end{array}$ & $\begin{array}{l}\text { Volume 185, } \\
\text { Part 1, } \\
2017, \\
\text { Pages 410- } \\
420\end{array}$ & $\begin{array}{l}\text { Microbial electrolysis } \\
\text { cell (MEC); Hydrogen } \\
(\mathrm{H} 2 \text { ) energy; Urban } \\
\text { wastewater; Waste- } \\
\text { to-energy (WTE); } \\
\text { Wastewater } \\
\text { treatment plant }\end{array}$ & India & Tecnologia & $\begin{array}{l}\text { Análises de } \\
\text { tecnologia }\end{array}$ & $\begin{array}{l}\text { Science } \\
\text { Direct }\end{array}$ \\
\hline $\begin{array}{l}\text { Applied } \\
\text { Energy }\end{array}$ & $\begin{array}{c}\text { Solar-assisted } \\
\text { integrated biogas } \\
\text { solid oxide fuel cell } \\
\text { (SOFC) installation in } \\
\text { wastewater } \\
\text { treatment plant: } \\
\text { Energy and economic } \\
\text { analysis }\end{array}$ & $\begin{array}{l}\text { A.S. Mehr, M. } \\
\text { Gandiglio, M. } \\
\text { MosayebNezhad, } \\
\text { A. Lanzini, S.M.S. } \\
\text { Mahmoudi, M. } \\
\text { Yari, M. } \\
\text { Santarelli }\end{array}$ & $\begin{array}{l}\text { Volume 191, } \\
\text { 2017, } \\
\text { Pages 620- } \\
638\end{array}$ & $\begin{array}{l}\text { Solid Oxide Fuel Cell; } \\
\text { Heat recovery; Solar } \\
\text { energy; WWTP; } \\
\text { Biogas; Economic } \\
\text { analysis }\end{array}$ & Irã & Tecnologia & $\begin{array}{l}\text { Eficiência no } \\
\text { tratamento }\end{array}$ & $\begin{array}{r}\text { Science } \\
\text { Direct }\end{array}$ \\
\hline $\begin{array}{c}\text { Water } \\
\text { Research }\end{array}$ & $\begin{array}{c}\text { Quantitative } \\
\text { assessment of energy } \\
\text { and resource } \\
\text { recovery in } \\
\text { wastewater }\end{array}$ & $\begin{array}{c}\text { T. Fernández- } \\
\text { Arévalo, I. } \\
\text { Lizarralde, F. } \\
\text { Fdz-Polanco, S.I. } \\
\text { Pérez-Elvira, J.M. }\end{array}$ & $\begin{array}{l}\text { Volume } 118, \\
2017, \\
\text { Pages 272- } \\
288\end{array}$ & $\begin{array}{l}\text { Energy and resource } \\
\text { recovery; Global mass } \\
\text { and energy balance; } \\
\text { Model-based }\end{array}$ & Espanha & Tecnologia & $\begin{array}{c}\text { Eficiência na } \\
\text { recuperação } \\
\text { energética }\end{array}$ & $\begin{array}{l}\text { Science } \\
\text { Direct }\end{array}$ \\
\hline
\end{tabular}




\begin{tabular}{|c|c|c|c|c|c|c|c|c|}
\hline \multirow[t]{2}{*}{ Revista } & Título do Artigo & Autor(es) & Referências & Palavras Chaves & $\begin{array}{l}\text { País de } \\
\text { Origem }\end{array}$ & Categoria & Subcategoria & Fonte \\
\hline & $\begin{array}{l}\text { treatment plants } \\
\text { based on plant-wide } \\
\text { simulations }\end{array}$ & $\begin{array}{c}\text { Garrido, S. Puig, } \\
\text { M. Poch, P. Grau, } \\
\text { E. Ayesa }\end{array}$ & & $\begin{array}{l}\text { assessment; Plant- } \\
\text { wide simulations }\end{array}$ & & & & \\
\hline $\begin{array}{l}\text { Bioresource } \\
\text { Technology }\end{array}$ & $\begin{array}{l}\text { A fluidized bed } \\
\text { membrane } \\
\text { bioelectrochemical } \\
\text { reactor for energy- } \\
\text { efficient wastewater } \\
\text { treatment }\end{array}$ & $\begin{array}{c}\text { Jian Li, Zheng Ge, } \\
\text { Zhen He }\end{array}$ & $\begin{array}{c}\text { Volume 167, } \\
\text { 2014, } \\
\text { Pages 310- } \\
315\end{array}$ & $\begin{array}{c}\text { Membrane } \\
\text { bioelectrochemical } \\
\text { reactor; Microbial fuel } \\
\text { cell; Bioenergy; } \\
\text { Wastewater } \\
\text { treatment; Fluidized } \\
\text { granular activated } \\
\text { carbon }\end{array}$ & $\begin{array}{l}\text { Estados } \\
\text { Unidos }\end{array}$ & Tecnologia & $\begin{array}{l}\text { Eficiência no } \\
\text { tratamento }\end{array}$ & $\begin{array}{r}\text { Science } \\
\text { Direct }\end{array}$ \\
\hline $\begin{array}{l}\text { Bioresource } \\
\text { Technology }\end{array}$ & $\begin{array}{l}\text { Evaluation of } \\
\text { normalized energy } \\
\text { recovery (NER) in } \\
\text { microbial fuel cells } \\
\text { affected by reactor } \\
\text { dimensions and } \\
\text { substrates }\end{array}$ & $\begin{array}{c}\text { Li Xiao, Zheng } \\
\text { Ge, Patrick Kelly, } \\
\text { Fei Zhang, Zhen } \\
\text { He }\end{array}$ & $\begin{array}{c}\text { Volume 157, } \\
\text { 2014, } \\
\text { Pages 77-83 }\end{array}$ & $\begin{array}{l}\text { Microbial fuel cell; } \\
\text { Normalized energy } \\
\text { recovery; Bioenergy; } \\
\text { Bioelectrochemical } \\
\text { system; Wastewater } \\
\text { treatment }\end{array}$ & $\begin{array}{l}\text { Estados } \\
\text { Unidos }\end{array}$ & Tecnologia & $\begin{array}{l}\text { Análises de } \\
\text { tecnologia }\end{array}$ & $\begin{array}{r}\text { Science } \\
\text { Direct }\end{array}$ \\
\hline $\begin{array}{l}\text { Science of The } \\
\text { Total } \\
\text { Environment }\end{array}$ & $\begin{array}{l}\text { Glocal assessment of } \\
\text { integrated } \\
\text { wastewater } \\
\text { treatment and } \\
\text { recovery concepts } \\
\text { using partial } \\
\text { nitritation/Anammox } \\
\text { and microalgae for } \\
\text { environmental } \\
\text { impacts }\end{array}$ & $\begin{array}{c}\text { Rungnapha } \\
\text { Khiewwijit, Huub } \\
\text { Rijnaarts, Hardy } \\
\text { Temmink, Karel } \\
\text { J. Keesman }\end{array}$ & $\begin{array}{c}\text { Volumes } \\
\text { 628-629, } \\
\text { 2018, } \\
\text { Pages 74-84 }\end{array}$ & $\begin{array}{c}\text { Wastewater } \\
\text { treatment; } \\
\text { Wastewater } \\
\text { management; } \\
\text { Microalgae reactor; } \\
\text { Energy recovery; } \\
\text { Nutrient recovery; } \\
\text { Effluent quality }\end{array}$ & $\begin{array}{l}\text { Países } \\
\text { Baixos }\end{array}$ & Gestão & Análise integrada & $\begin{array}{r}\text { Science } \\
\text { Direct }\end{array}$ \\
\hline $\begin{array}{c}\text { Science of The } \\
\text { Total } \\
\text { Environment }\end{array}$ & $\begin{array}{l}\text { Options to reduce } \\
\text { greenhouse gas } \\
\text { emissions during } \\
\text { wastewater } \\
\text { treatment for } \\
\text { agricultural use }\end{array}$ & $\begin{array}{l}\text { Pinchas Fine, } \\
\text { Efrat Hadas }\end{array}$ & $\begin{array}{c}\text { Volume 416, } \\
2012, \\
\text { Pages 289- } \\
299\end{array}$ & $\begin{array}{c}\text { Biological nutrient } \\
\text { removal (BNR); } \\
\text { Biosolids; Effluent } \\
\text { irrigation; Biogas; } \\
\text { Energy recovery; } \\
\text { Fertilizer recovery }\end{array}$ & Israel & Impacto & $\begin{array}{c}\text { Gases do Efeito } \\
\text { Estufa }\end{array}$ & $\begin{array}{r}\text { Science } \\
\text { Direct }\end{array}$ \\
\hline $\begin{array}{c}\text { Journal of } \\
\text { Environmental } \\
\text { Management }\end{array}$ & $\begin{array}{l}\text { How far are we from } \\
\text { closing the loop of } \\
\text { sewage resource } \\
\text { recovery? A real } \\
\text { picture of municipal } \\
\text { wastewater } \\
\text { treatment plants in } \\
\text { Italy }\end{array}$ & $\begin{array}{c}\text { Matteo Papa, } \\
\text { Paola Foladori, } \\
\text { Lorena } \\
\text { Guglielmi, } \\
\text { Giorgio Bertanza }\end{array}$ & $\begin{array}{c}\text { Volume 198, } \\
\text { Part 1, } \\
\text { 2017, } \\
\text { Pages 9-15 }\end{array}$ & $\begin{array}{c}\text { Wastewater } \\
\text { treatment plants; } \\
\text { Material recovery; } \\
\text { Energy recovery; } \\
\text { Italian survey; } \\
\text { Sustainability }\end{array}$ & Itália & Gestão & Análise integrada & $\begin{array}{r}\text { Science } \\
\text { Direct }\end{array}$ \\
\hline $\begin{array}{c}\text { Water } \\
\text { Research }\end{array}$ & $\begin{array}{l}\text { CO2-neutral } \\
\text { wastewater } \\
\text { treatment plants or } \\
\text { robust, climate- } \\
\text { friendly wastewater } \\
\text { management? A } \\
\text { systems perspective }\end{array}$ & Tove A. Larsen & $\begin{array}{l}\text { Volume 87, } \\
2015, \\
\text { Pages 513- } \\
521\end{array}$ & $\begin{array}{l}\text { Warm greywater; } \\
\text { Decentralized heat } \\
\text { recovery; Cold } \\
\text { wastewater; Urine } \\
\text { separation; Future }\end{array}$ & Suíça & Impacto & $\begin{array}{c}\text { Gases do Efeito } \\
\text { Estufa }\end{array}$ & $\begin{array}{r}\text { Science } \\
\text { Direct }\end{array}$ \\
\hline
\end{tabular}




\begin{tabular}{|c|c|c|c|c|c|c|c|c|}
\hline Revista & Título do Artigo & Autor(es) & Referências & Palavras Chaves & $\begin{array}{l}\text { País de } \\
\text { Origem }\end{array}$ & Categoria & Subcategoria & Fonte \\
\hline $\begin{array}{l}\text { Bioresource } \\
\text { Technology }\end{array}$ & $\begin{array}{l}\text { In situ investigation of } \\
\text { processing property } \\
\text { in combination with } \\
\text { integration of } \\
\text { microbial fuel cell and } \\
\text { tubular membrane } \\
\text { bioreactor }\end{array}$ & $\begin{array}{l}\text { Jie Wang, Yawen } \\
\text { Zheng, Hui Jia, } \\
\text { Hongwei Zhang }\end{array}$ & $\begin{array}{c}\text { Volume 149, } \\
2013, \\
\text { Pages 163- } \\
168\end{array}$ & $\begin{array}{l}\text { Microbial fuel cell } \\
\text { (MFC); Tubular } \\
\text { membrane bioreactor } \\
\text { (TMBR); Energy } \\
\text { recovery; Wastewater } \\
\text { treatment; } \\
\text { Membrane fouling }\end{array}$ & China & Tecnologia & $\begin{array}{l}\text { Análises de } \\
\text { tecnologia }\end{array}$ & $\begin{array}{r}\text { Science } \\
\text { Direct }\end{array}$ \\
\hline $\begin{array}{c}\text { Journal of } \\
\text { Environmental } \\
\text { Management }\end{array}$ & $\begin{array}{l}\text { Quantifying benefits } \\
\text { of resource recovery } \\
\text { from sanitation } \\
\text { provision in a } \\
\text { developing world } \\
\text { setting }\end{array}$ & $\begin{array}{l}\text { Pablo K. Cornejo, } \\
\text { Qiong Zhang, } \\
\text { James R. } \\
\text { Mihelcic }\end{array}$ & $\begin{array}{c}\text { Volume 131, } \\
\text { 2013, } \\
\text { Pages 7-15 }\end{array}$ & $\begin{array}{c}\text { Sustainability; } \\
\text { Millennium } \\
\text { development goals; } \\
\text { Small-scale sewage } \\
\text { systems; } \\
\text { Eutrophication } \\
\text { potential; Nutrients; } \\
\text { Carbon footprint }\end{array}$ & $\begin{array}{l}\text { Estados } \\
\text { Unidos }\end{array}$ & Impacto & $\begin{array}{c}\text { Desenvolvimento } \\
\text { Sustentável }\end{array}$ & $\begin{array}{r}\text { Science } \\
\text { Direct }\end{array}$ \\
\hline $\begin{array}{l}\text { Bioresource } \\
\text { Technology }\end{array}$ & $\begin{array}{l}\text { Enhanced methane } \\
\text { production in a two- } \\
\text { phase anaerobic } \\
\text { digestion plant, after } \\
\mathrm{CO} 2 \text { capture and } \\
\text { addition to organic } \\
\text { wastes }\end{array}$ & $\begin{array}{l}\text { C. Salomoni, A. } \\
\text { Caputo, M. } \\
\text { Bonoli, O. } \\
\text { Francioso, M.T. } \\
\text { Rodriguez- } \\
\text { Estrada, D. } \\
\text { Palenzona }\end{array}$ & $\begin{array}{c}\text { Volume } 102, \\
\text { Issue } 11, \\
2011 \\
\text { Pages } 6443- \\
6448\end{array}$ & $\begin{array}{l}\text { CO2 capture; Two- } \\
\text { phase anaerobic } \\
\text { digestion; } \\
\text { Biomethane } \\
\text { production; } \\
\text { Biomethanation; } \\
\text { Biogas }\end{array}$ & Itália & Tecnologia & $\begin{array}{l}\text { Eficiência na } \\
\text { recuperação } \\
\text { energética }\end{array}$ & $\begin{array}{l}\text { Science } \\
\text { Direct }\end{array}$ \\
\hline $\begin{array}{l}\text { Science of The } \\
\text { Total } \\
\text { Environment }\end{array}$ & $\begin{array}{l}\text { Balancing effluent } \\
\text { quality, economic } \\
\text { cost and greenhouse } \\
\text { gas emissions during } \\
\text { the evaluation of } \\
\text { (plant-wide) } \\
\text { control/operational } \\
\text { strategies in WWTPs }\end{array}$ & $\begin{array}{c}\text { Xavier Flores- } \\
\text { Alsina, Magnus } \\
\text { Arnell, Youri } \\
\text { Amerlinck, Lluís } \\
\text { Corominas, Krist } \\
\text { V. Gernaey, Lisha } \\
\text { Guo, Erik } \\
\text { Lindblom, } \\
\text { Ingmar Nopens, } \\
\text { Jose Porro, Andy } \\
\text { Shaw, Laura } \\
\text { Snip, Peter A. } \\
\text { Vanrolleghem, } \\
\text { Ulf Jeppsson }\end{array}$ & $\begin{array}{c}\text { Volumes } \\
\text { 466-467, } \\
2014, \\
\text { Pages 616- } \\
624\end{array}$ & $\begin{array}{l}\text { Benchmarking; Global } \\
\text { warming; Model- } \\
\text { based evaluation; } \\
\text { Multi-criteria decision } \\
\text { making; Process } \\
\text { control; Sustainability }\end{array}$ & Suécia & Gestão & $\begin{array}{l}\text { Modelagem } \\
\text { matemática }\end{array}$ & $\begin{array}{l}\text { Science } \\
\text { Direct }\end{array}$ \\
\hline $\begin{array}{c}\text { Water } \\
\text { Research }\end{array}$ & $\begin{array}{l}\text { City-scale analysis of } \\
\text { water-related energy } \\
\text { identifies more cost- } \\
\text { effective solutions }\end{array}$ & $\begin{array}{l}\text { Ka Leung Lam, } \\
\text { Steven J. } \\
\text { Kenway, Paul A. } \\
\text { Lant }\end{array}$ & $\begin{array}{c}\text { Volume 109, } \\
2017, \\
\text { Pages 287- } \\
298\end{array}$ & $\begin{array}{l}\text { Urban water system; } \\
\text { Water utility; End use; } \\
\text { Cost curve; Energy } \\
\text { management; } \\
\text { Greenhouse gas } \\
\text { management }\end{array}$ & Australia & Gestão & $\begin{array}{l}\text { Modelagem } \\
\text { matemática }\end{array}$ & $\begin{array}{l}\text { Science } \\
\text { Direct }\end{array}$ \\
\hline $\begin{array}{c}\text { Water } \\
\text { Research }\end{array}$ & $\begin{array}{l}\text { Digestion of high rate } \\
\text { activated sludge } \\
\text { coupled to biochar } \\
\text { formation for soil } \\
\text { improvement in the } \\
\text { tropics }\end{array}$ & $\begin{array}{c}\text { Irene } \\
\text { Nansubuga, } \\
\text { Noble Banadda, } \\
\text { Frederik Ronsse, } \\
\text { Willy Verstraete, } \\
\text { Korneel Rabaey }\end{array}$ & 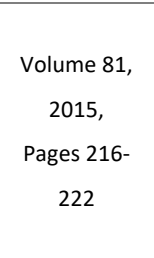 & $\begin{array}{l}\text { A-stage; Pyrolysis; } \\
\text { Sludge reuse; } \\
\text { Agriculture; Energy }\end{array}$ & Bélgica & Tecnologia & $\begin{array}{l}\text { Tecnologias } \\
\text { alternativas }\end{array}$ & $\begin{array}{l}\text { Science } \\
\text { Direct }\end{array}$ \\
\hline
\end{tabular}




\begin{tabular}{|c|c|c|c|c|c|c|c|c|}
\hline Revista & Título do Artigo & Autor(es) & Referências & Palavras Chaves & $\begin{array}{l}\text { País de } \\
\text { Origem }\end{array}$ & Categoria & Subcategoria & Fonte \\
\hline $\begin{array}{l}\text { Applied } \\
\text { Energy }\end{array}$ & $\begin{array}{l}\text { Energetic and } \\
\text { environmental } \\
\text { sustainability of the } \\
\text { co-digestion of sludge } \\
\text { with bio-waste in a } \\
\text { life cycle perspective }\end{array}$ & $\begin{array}{l}\text { Francesco Di } \\
\text { Maria, Caterina } \\
\text { Micale, Stefano } \\
\text { Contini }\end{array}$ & $\begin{array}{c}\text { Volume 171, } \\
\text { 2016, } \\
\text { Pages 67-76 }\end{array}$ & $\begin{array}{l}\text { Anaerobic co- } \\
\text { digestion; Biogas; } \\
\text { Composting; Energy } \\
\text { recovery; Fruit and } \\
\text { vegetable waste; } \\
\text { Waste-mixed sludge; } \\
\text { Life cycle analysis; } \\
\text { Uncertainty }\end{array}$ & Itália & Impacto & $\begin{array}{c}\text { Análise do Ciclo } \\
\text { de Vida }\end{array}$ & $\begin{array}{r}\text { Science } \\
\text { Direct }\end{array}$ \\
\hline $\begin{array}{l}\text { Science of The } \\
\text { Total } \\
\text { Environment }\end{array}$ & $\begin{array}{c}\text { Life cycle GHG } \\
\text { emissions of sewage } \\
\text { sludge treatment and } \\
\text { disposal options in Tai } \\
\text { Lake Watershed, } \\
\text { China }\end{array}$ & $\begin{array}{c}\text { Beibei Liu, Qi } \\
\text { Wei, Bing Zhang, } \\
\text { Jun Bi }\end{array}$ & $\begin{array}{c}\text { Volume } 447 \\
2013, \\
\text { Pages } 361- \\
369\end{array}$ & $\begin{array}{l}\text { Sewage sludge } \\
\text { management; } \\
\text { Greenhouse gas } \\
\text { emission; Life cycle } \\
\text { analysis }\end{array}$ & China & Impacto & $\begin{array}{c}\text { Gases do Efeito } \\
\text { Estufa }\end{array}$ & $\begin{array}{r}\text { Science } \\
\text { Direct }\end{array}$ \\
\hline $\begin{array}{l}\text { Bioresource } \\
\text { Technology }\end{array}$ & $\begin{array}{c}\text { Environmental impact } \\
\text { of submerged } \\
\text { anaerobic MBR } \\
\text { (SAnMBR) technology } \\
\text { used to treat urban } \\
\text { wastewater at } \\
\text { different } \\
\text { temperatures }\end{array}$ & $\begin{array}{c}\text { R. Pretel, A. } \\
\text { Robles, M.V. } \\
\text { Ruano, A. Seco, } \\
\text { J. Ferrer }\end{array}$ & $\begin{array}{l}\text { Volume 149, } \\
2013 \text {, } \\
\text { Pages 532- } \\
540\end{array}$ & $\begin{array}{c}\text { Energy balance; } \\
\text { Global warming } \\
\text { potential; Life cycle } \\
\text { assessment; } \\
\text { Submerged anaerobic } \\
\text { MBR (SAnMBR); } \\
\text { Environmental impact }\end{array}$ & Espanha & Impacto & $\begin{array}{l}\text { Impacto } \\
\text { ambiental }\end{array}$ & $\begin{array}{r}\text { Science } \\
\text { Direct }\end{array}$ \\
\hline $\begin{array}{l}\text { Bioresource } \\
\text { Technology }\end{array}$ & $\begin{array}{l}\text { Carbon and nitrogen } \\
\text { removal and } \\
\text { enhanced methane } \\
\text { production in a } \\
\text { microbial electrolysis } \\
\text { cell }\end{array}$ & $\begin{array}{c}\text { Marianna } \\
\text { Villano, Stefano } \\
\text { Scardala, } \\
\text { Federico } \\
\text { Aulenta, Mauro } \\
\text { Majone }\end{array}$ & $\begin{array}{c}\text { Volume 130, } \\
\begin{array}{c}2013 \\
\text { Pages } 366- \\
371\end{array}\end{array}$ & $\begin{array}{l}\text { Microbial electrolysis } \\
\text { cell; Biocathode; } \\
\text { Methane } \\
\text { bioproduction; } \\
\text { Ammonium recovery }\end{array}$ & Itália & Tecnologia & $\begin{array}{c}\text { Eficiência na } \\
\text { recuperação } \\
\text { energética }\end{array}$ & $\begin{array}{r}\text { Science } \\
\text { Direct }\end{array}$ \\
\hline $\begin{array}{l}\text { Bioresource } \\
\text { Technology }\end{array}$ & $\begin{array}{l}\text { Techno-economic } \\
\text { analysis of } \\
\text { wastewater sludge } \\
\text { gasification: A } \\
\text { decentralized urban } \\
\text { perspective }\end{array}$ & $\begin{array}{c}\text { Nicholas P.G. } \\
\text { Lumley, Dotti F. } \\
\text { Ramey, Ana L. } \\
\text { Prieto, Robert J. } \\
\text { Braun, Tzahi Y. } \\
\text { Cath, Jason M. } \\
\text { Porter }\end{array}$ & $\begin{array}{c}\text { Volume 161, } \\
\text { 2014, } \\
\text { Pages 385- } \\
394\end{array}$ & $\begin{array}{l}\text { Gasification; Techno- } \\
\text { economic analysis; } \\
\text { Sewage sludge; } \\
\text { Thermochemical } \\
\text { conversion; } \\
\text { Renewable energy }\end{array}$ & $\begin{array}{l}\text { Estados } \\
\text { Unidos }\end{array}$ & Gestão & Análise integrada & $\begin{array}{r}\text { Science } \\
\text { Direct }\end{array}$ \\
\hline $\begin{array}{c}\text { Water } \\
\text { Research }\end{array}$ & $\begin{array}{l}\text { Environmental } \\
\text { sustainability of an } \\
\text { energy self-sufficient } \\
\text { sewage treatment } \\
\text { plant: Improvements } \\
\text { through DEMON and } \\
\text { co-digestion }\end{array}$ & $\begin{array}{c}\text { Thomas } \\
\text { Schaubroeck, } \\
\text { Haydée De } \\
\text { Clippeleir, } \\
\text { Norbert } \\
\text { Weissenbacher, } \\
\text { Jo Dewulf, Pascal } \\
\text { Boeckx, Siegfried } \\
\text { E. Vlaeminck, } \\
\text { Bernhard Wett }\end{array}$ & $\begin{array}{c}\text { Volume } 74, \\
2015, \\
\text { Pages 166- } \\
179\end{array}$ & $\begin{array}{l}\text { Wastewater } \\
\text { treatment; Recovery; } \\
\text { Sustainability; } \\
\text { Autotrophic nitrogen } \\
\text { removal; Life cycle } \\
\text { assessment; } \\
\text { Anammox }\end{array}$ & Bélgica & Impacto & $\begin{array}{c}\text { Análise do Ciclo } \\
\text { de Vida }\end{array}$ & $\begin{array}{r}\text { Science } \\
\text { Direct }\end{array}$ \\
\hline $\begin{array}{c}\text { Water } \\
\text { Research }\end{array}$ & $\begin{array}{c}\text { Navigating } \\
\text { environmental, } \\
\text { economic, and } \\
\text { technological trade- } \\
\text { offs in the design and } \\
\text { operation of }\end{array}$ & $\begin{array}{l}\text { R. Pretel, B.D. } \\
\text { Shoener, J. } \\
\text { Ferrer, J.S. Guest }\end{array}$ & $\begin{array}{l}\text { Volume 87, } \\
2015, \\
\text { Pages 531- } \\
541\end{array}$ & $\begin{array}{c}\text { Anaerobic MBR; } \\
\text { Biomethane; Global } \\
\text { warming potential; } \\
\text { Life cycle analysis; } \\
\text { Renewable energy; } \\
\text { Carbon neutral }\end{array}$ & Espanha & Tecnologia & $\begin{array}{l}\text { Análises de } \\
\text { tecnologia }\end{array}$ & $\begin{array}{l}\text { Science } \\
\text { Direct }\end{array}$ \\
\hline
\end{tabular}




\begin{tabular}{|c|c|c|c|c|c|c|c|c|}
\hline Revista & Título do Artigo & Autor(es) & Referências & Palavras Chaves & $\begin{array}{l}\text { País de } \\
\text { Origem }\end{array}$ & Categoria & Subcategoria & Fonte \\
\hline & $\begin{array}{l}\text { submerged anaerobic } \\
\text { membrane } \\
\text { bioreactors (AnMBRs) }\end{array}$ & & & & & & & \\
\hline $\begin{array}{c}\text { Water } \\
\text { Research }\end{array}$ & $\begin{array}{l}\text { The diverse } \\
\text { environmental } \\
\text { burden of city-scale } \\
\text { urban water systems }\end{array}$ & $\begin{array}{c}\text { J.L. Lane, D.W. } \\
\text { de Haas, P.A. } \\
\text { Lant }\end{array}$ & $\begin{array}{l}\text { Volume 81, } \\
\begin{array}{c}2015 \\
\text { Pages } 398- \\
415\end{array}\end{array}$ & $\begin{array}{l}\text { Life Cycle Assessment } \\
\text { (LCA); Urban water } \\
\text { system; Ozone } \\
\text { depletion; } \\
\text { Greenhouse gas; } \\
\text { Phosphorus recovery; } \\
\text { Toxicity }\end{array}$ & Austrália & Impacto & $\begin{array}{c}\text { Análise do Ciclo } \\
\text { de Vida }\end{array}$ & $\begin{array}{r}\text { Science } \\
\text { Direct }\end{array}$ \\
\hline $\begin{array}{c}\text { Water } \\
\text { Research }\end{array}$ & $\begin{array}{l}\text { Free ammonia pre- } \\
\text { treatment of } \\
\text { secondary sludge } \\
\text { significantly increases } \\
\text { anaerobic methane } \\
\text { production }\end{array}$ & $\begin{array}{c}\text { Wei Wei, Xu } \\
\text { Zhou, Dongbo } \\
\text { Wang, Jing Sun, } \\
\text { Qilin Wang }\end{array}$ & $\begin{array}{c}\text { Volume 118, } \\
\text { 2017, } \\
\text { Pages 12-19 }\end{array}$ & $\begin{array}{c}\text { Free ammonia; } \\
\text { Secondary sludge; } \\
\text { Anaerobic digestion; } \\
\text { Energy; Methane; } \\
\text { Degradability }\end{array}$ & Austrália & Tecnologia & $\begin{array}{c}\text { Eficiência na } \\
\text { recuperação } \\
\text { energética }\end{array}$ & $\begin{array}{r}\text { Science } \\
\text { Direct }\end{array}$ \\
\hline $\begin{array}{c}\text { Journal of } \\
\text { Environmental } \\
\text { Management }\end{array}$ & $\begin{array}{l}\text { The energy-water- } \\
\text { food nexus: Strategic } \\
\text { analysis of } \\
\text { technologies for } \\
\text { transforming the } \\
\text { urban metabolism }\end{array}$ & $\begin{array}{l}\text { R. Villarroel } \\
\text { Walker, M.B. } \\
\text { Beck, J.W. Hall, } \\
\text { R.J. Dawson, O. } \\
\text { Heidrich }\end{array}$ & $\begin{array}{c}\text { Volume 141, } \\
2014, \\
\text { Pages 104- } \\
115\end{array}$ & $\begin{array}{c}\text { Resource recovery; } \\
\text { Decision-making; } \\
\text { Nutrients; Energy; } \\
\text { Wastewater }\end{array}$ & $\begin{array}{l}\text { Estados } \\
\text { Unidos }\end{array}$ & Gestão & $\begin{array}{l}\text { Nexus Energia- } \\
\text { Água-Alimento }\end{array}$ & $\begin{array}{r}\text { Science } \\
\text { Direct }\end{array}$ \\
\hline $\begin{array}{l}\text { Bioresource } \\
\text { Technology }\end{array}$ & $\begin{array}{l}\text { A horizontal plug flow } \\
\text { and stackable pilot } \\
\text { microbial fuel cell for } \\
\text { municipal wastewater } \\
\text { treatment }\end{array}$ & $\begin{array}{l}\text { Yujie Feng, } \\
\text { Weihua He, Jia } \\
\text { Liu, Xin Wang, } \\
\text { Youpeng Qu, } \\
\text { Nanqi Ren }\end{array}$ & $\begin{array}{c}\text { Volume 156, } \\
\text { 2014, } \\
\text { Pages 132- } \\
138\end{array}$ & $\begin{array}{l}\text { Microbial fuel cell; } \\
\text { Stackable horizontal } \\
\text { MFC (SHMFC); } \\
\text { Sewage wastewater } \\
\text { treatment; Electricity } \\
\text { generation }\end{array}$ & China & Tecnologia & $\begin{array}{l}\text { Análises de } \\
\text { tecnologia }\end{array}$ & $\begin{array}{r}\text { Science } \\
\text { Direct }\end{array}$ \\
\hline $\begin{array}{l}\text { Applied } \\
\text { Energy }\end{array}$ & $\begin{array}{c}\text { Energy recovery } \\
\text { evaluation in an up } \\
\text { flow microbial } \\
\text { electrolysis coupled } \\
\text { anaerobic digestion } \\
\text { (ME-AD) reactor: Role } \\
\text { of electrode positions } \\
\text { and hydraulic } \\
\text { retention times }\end{array}$ & $\begin{array}{l}\text { Thangavel } \\
\text { Sangeetha, } \\
\text { Zechong Guo, } \\
\text { Wenzong Liu, Lei } \\
\text { Gao, Ling Wang, } \\
\text { Minhua Cui, } \\
\text { Chuan Chen, } \\
\text { Aijie Wang }\end{array}$ & $\begin{array}{c}\text { Volume 206, } \\
2017, \\
\text { Pages 1214- } \\
1224\end{array}$ & $\begin{array}{l}\text { Integrated reactor; } \\
\text { Bioelectrochemical } \\
\text { system; Hydraulic } \\
\text { retention time; } \\
\text { Electrode position; } \\
\text { Applied voltage; } \\
\text { Microbial community }\end{array}$ & China & Tecnologia & $\begin{array}{c}\text { Eficiência na } \\
\text { recuperação } \\
\text { energética }\end{array}$ & $\begin{array}{l}\text { Science } \\
\text { Direct }\end{array}$ \\
\hline $\begin{array}{c}\text { Water } \\
\text { Research }\end{array}$ & $\begin{array}{l}\text { Using bioprocess } \\
\text { stoichiometry to build } \\
\text { a plant-wide mass } \\
\text { balance based steady- } \\
\text { state WWTP model }\end{array}$ & G.A. Ekama & $\begin{array}{l}\text { Volume } 43, \\
\text { Issue } 8, \\
2009 \\
\text { Pages } 2101- \\
2120\end{array}$ & $\begin{array}{c}\text { Wastewater } \\
\text { treatment plants; } \\
\text { Stoichiometry; } \\
\text { Steady-state models; } \\
\text { Elemental mass } \\
\text { balances }\end{array}$ & $\begin{array}{c}\text { África do } \\
\text { Sul }\end{array}$ & Gestão & $\begin{array}{l}\text { Modelagem } \\
\text { matemática }\end{array}$ & $\begin{array}{r}\text { Science } \\
\text { Direct }\end{array}$ \\
\hline $\begin{array}{c}\text { Water } \\
\text { Research }\end{array}$ & $\begin{array}{l}\text { Comprehensive life } \\
\text { cycle inventories of } \\
\text { alternative } \\
\text { wastewater } \\
\text { treatment systems }\end{array}$ & $\begin{array}{l}\text { Jeffrey Foley, } \\
\text { David de Haas, } \\
\text { Ken Hartley, Paul } \\
\text { Lant }\end{array}$ & $\begin{array}{l}\text { Volume 44, } \\
\text { Issue 5, } \\
\text { 2010, } \\
\text { Pages 1654- } \\
1666\end{array}$ & $\begin{array}{l}\text { Life cycle inventory; } \\
\text { Biological nutrient } \\
\text { removal; Energy; } \\
\text { Nutrient recovery; } \\
\text { Global environmental } \\
\text { impacts; Effluent } \\
\text { standards; } \\
\text { Greenhouse gas }\end{array}$ & Austrália & Impacto & $\begin{array}{c}\text { Análise do Ciclo } \\
\text { de Vida }\end{array}$ & $\begin{array}{r}\text { Science } \\
\text { Direct }\end{array}$ \\
\hline
\end{tabular}




\begin{tabular}{|c|c|c|c|c|c|c|c|c|}
\hline Revista & Título do Artigo & Autor(es) & Referências & Palavras Chaves & $\begin{array}{l}\text { País de } \\
\text { Origem }\end{array}$ & Categoria & Subcategoria & Fonte \\
\hline $\begin{array}{c}\text { Water } \\
\text { Research }\end{array}$ & $\begin{array}{l}\text { Evaluation of the } \\
\text { potential for } \\
\text { operating carbon } \\
\text { neutral WWTPs in } \\
\text { China }\end{array}$ & $\begin{array}{l}\text { Xiaodi Hao, } \\
\text { Ranbin Liu, Xin } \\
\text { Huang }\end{array}$ & 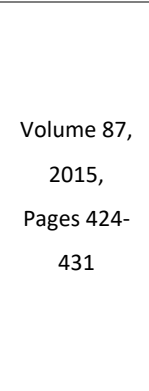 & $\begin{array}{l}\text { Carbon neutrality; } \\
\text { Wastewater } \\
\text { treatment plants } \\
\text { (WWTPs); Organic } \\
\text { energy; Anaerobic } \\
\text { digestion; Water } \\
\text { source heat pumps } \\
\text { (WSHP); Photovoltaic } \\
\text { (PV) technology }\end{array}$ & China & Impacto & $\begin{array}{c}\text { Gases do Efeito } \\
\text { Estufa }\end{array}$ & $\begin{array}{r}\text { Science } \\
\text { Direct }\end{array}$ \\
\hline $\begin{array}{c}\text { Water } \\
\text { Research }\end{array}$ & $\begin{array}{c}\text { Performance of a } \\
\text { submerged anaerobic } \\
\text { membrane bioreactor } \\
\text { with forward osmosis } \\
\text { membrane for low- } \\
\text { strength wastewater } \\
\text { treatment }\end{array}$ & $\begin{array}{l}\text { Lin Chen, } \\
\text { Yangshuo Gu, } \\
\text { Chuqing Cao, Jun } \\
\text { Zhang, Jing-Wen } \\
\text { Ng, Chuyang } \\
\text { Tang }\end{array}$ & $\begin{array}{c}\text { Volume 50, } \\
2014, \\
\text { Pages 114- } \\
123\end{array}$ & $\begin{array}{l}\text { Forward osmosis } \\
\text { membrane; Anaerobic } \\
\text { bioreactor; Salinity; } \\
\text { Wastewater } \\
\text { treatment }\end{array}$ & Singapura & Tecnologia & $\begin{array}{l}\text { Análises de } \\
\text { tecnologia }\end{array}$ & $\begin{array}{r}\text { Science } \\
\text { Direct }\end{array}$ \\
\hline $\begin{array}{l}\text { Bioresource } \\
\text { Technology }\end{array}$ & $\begin{array}{l}\text { Direct sewage up- } \\
\text { concentration by } \\
\text { submerged aerated } \\
\text { and vibrated } \\
\text { membranes }\end{array}$ & $\begin{array}{l}\text { G. Mezohegyi, } \\
\text { M.R. Bilad, Ivo } \\
\text { F.J. Vankelecom }\end{array}$ & $\begin{array}{c}\text { Volume 118, } \\
\text { 2012, } \\
\text { Pages 1-7 }\end{array}$ & $\begin{array}{l}\text { COD concentration; } \\
\text { Energy recovery; } \\
\text { Membrane filtration; } \\
\text { Membrane vibration; } \\
\text { Sewage wastewater }\end{array}$ & Bélgica & Tecnologia & $\begin{array}{l}\text { Análises de } \\
\text { tecnologia }\end{array}$ & $\begin{array}{r}\text { Science } \\
\text { Direct }\end{array}$ \\
\hline $\begin{array}{c}\text { Water } \\
\text { Research }\end{array}$ & $\begin{array}{l}\text { Evaluation of new } \\
\text { alternatives in } \\
\text { wastewater } \\
\text { treatment plants } \\
\text { based on dynamic } \\
\text { modelling and life } \\
\text { cycle assessment } \\
\text { (DM-LCA) }\end{array}$ & $\begin{array}{l}\text { A.B. Bisinella de } \\
\text { Faria, M. } \\
\text { Spérandio, A. } \\
\text { Ahmadi, L. } \\
\text { Tiruta-Barna }\end{array}$ & $\begin{array}{c}\text { Volume } 84 \\
2015 \\
\text { Pages } 99-111\end{array}$ & $\begin{array}{c}\text { WWTP; Dynamic } \\
\text { modelling; Integrated } \\
\text { LCA; Urine separation; } \\
\text { Enhanced primary } \\
\text { clarification; Struvite }\end{array}$ & França & Tecnologia & $\begin{array}{l}\text { Tecnologias } \\
\text { alternativas }\end{array}$ & $\begin{array}{r}\text { Science } \\
\text { Direct }\end{array}$ \\
\hline $\begin{array}{l}\text { Applied } \\
\text { Energy }\end{array}$ & $\begin{array}{l}\text { Amount of energy } \\
\text { recoverable from an } \\
\text { existing sludge } \\
\text { digester with the co- } \\
\text { digestion with fruit } \\
\text { and vegetable waste } \\
\text { at reduced retention } \\
\text { time }\end{array}$ & $\begin{array}{c}\text { Francesco Di } \\
\text { Maria, Alessio } \\
\text { Sordi, Giuseppe } \\
\text { Cirulli, Caterina } \\
\text { Micale }\end{array}$ & $\begin{array}{c}\text { Volume 150, } \\
\text { 2015, } \\
\text { Pages 9-14 }\end{array}$ & $\begin{array}{l}\text { Anaerobic co- } \\
\text { digestion; } \\
\text { Biomethane; Energy } \\
\text { recovery; Fruit and } \\
\text { vegetable waste; } \\
\text { Organic loading rate; } \\
\text { Waste-mixed sludge }\end{array}$ & Itália & Tecnologia & $\begin{array}{l}\text { Tecnologias } \\
\text { alternativas }\end{array}$ & $\begin{array}{r}\text { Science } \\
\text { Direct }\end{array}$ \\
\hline $\begin{array}{c}\text { Water } \\
\text { Research }\end{array}$ & $\begin{array}{c}\text { Impact of process } \\
\text { design on greenhouse } \\
\text { gas (GHG) generation } \\
\text { by wastewater } \\
\text { treatment plants }\end{array}$ & $\begin{array}{c}\text { M. Bani } \\
\text { Shahabadi, L. } \\
\text { Yerushalmi, F. } \\
\text { Haghighat }\end{array}$ & $\begin{array}{l}\text { Volume } 43, \\
\text { Issue } 10, \\
2009 \\
\text { Pages } 2679 \text { - } \\
2687\end{array}$ & $\begin{array}{l}\text { Greenhouse gas; } \\
\text { Wastewater } \\
\text { treatment; On-site } \\
\text { emissions; Off-site } \\
\text { emissions; Hybrid } \\
\text { process }\end{array}$ & Canada & Impacto & $\begin{array}{c}\text { Gases do Efeito } \\
\text { Estufa }\end{array}$ & $\begin{array}{r}\text { Science } \\
\text { Direct }\end{array}$ \\
\hline $\begin{array}{l}\text { Science of The } \\
\text { Total } \\
\text { Environment }\end{array}$ & $\begin{array}{c}\text { Anaerobic co- } \\
\text { digestion of source } \\
\text { segregated brown } \\
\text { water (feces-without- } \\
\text { urine) and food } \\
\text { waste: For Singapore } \\
\text { context }\end{array}$ & $\begin{array}{l}\text { Rajinikanth } \\
\text { Rajagopal, Jun } \\
\text { Wei Lim, Yu } \\
\text { Mao, Chia-Lung } \\
\text { Chen, Jing-Yuan } \\
\text { Wang }\end{array}$ & $\begin{array}{c}\text { Volume 443, } \\
\text { 2013, } \\
\text { Pages 877- } \\
886\end{array}$ & $\begin{array}{c}\text { Anaerobic co- } \\
\text { digestion; Brown } \\
\text { water; Food waste; } \\
\text { Source separation; } \\
\text { Volatile fatty acids } \\
\text { (VFAs) }\end{array}$ & Singapura & Tecnologia & $\begin{array}{l}\text { Tecnologias } \\
\text { alternativas }\end{array}$ & $\begin{array}{r}\text { Science } \\
\text { Direct }\end{array}$ \\
\hline
\end{tabular}




\begin{tabular}{|c|c|c|c|c|c|c|c|c|}
\hline Revista & Título do Artigo & Autor(es) & Referências & Palavras Chaves & $\begin{array}{l}\text { País de } \\
\text { Origem }\end{array}$ & Categoria & Subcategoria & Fonte \\
\hline $\begin{array}{c}\text { Water } \\
\text { Research }\end{array}$ & $\begin{array}{l}\text { High-rate activated } \\
\text { sludge communities } \\
\text { have a distinctly } \\
\text { different structure } \\
\text { compared to low-rate } \\
\text { sludge communities, } \\
\text { and are less sensitive } \\
\text { towards } \\
\text { environmental and } \\
\text { operational variables }\end{array}$ & $\begin{array}{c}\text { Francis A. } \\
\text { Meerburg, } \\
\text { Siegfried E. } \\
\text { Vlaeminck, Hugo } \\
\text { Roume, Dries } \\
\text { Seuntjens, } \\
\text { Dietmar H. } \\
\text { Pieper, Ruy } \\
\text { Jauregui, Ramiro } \\
\text { Vilchez-Vargas, } \\
\text { Nico Boon }\end{array}$ & $\begin{array}{c}\text { Volume 100, } \\
\text { 2016, } \\
\text { Pages 137- } \\
145\end{array}$ & $\begin{array}{l}\text { A-stage; AB-system; } \\
\text { Energy-neutral } \\
\text { sewage treatment; } \\
\text { Co-occurrence } \\
\text { network analysis; } \\
\text { Resource recovery }\end{array}$ & Bélgica & Gestão & Análise integrada & $\begin{array}{r}\text { Science } \\
\text { Direct }\end{array}$ \\
\hline $\begin{array}{c}\text { Water } \\
\text { Research }\end{array}$ & $\begin{array}{l}\text { Cost, energy, global } \\
\text { warming, } \\
\text { eutrophication and } \\
\text { local human health } \\
\text { impacts of } \\
\text { community water and } \\
\text { sanitation service } \\
\text { options }\end{array}$ & $\begin{array}{l}\text { Mary E. Schoen, } \\
\text { Xiaobo Xue, } \\
\text { Alison Wood, } \\
\text { Troy R. Hawkins, } \\
\text { Jay Garland, } \\
\text { Nicholas J. } \\
\text { Ashbolt }\end{array}$ & $\begin{array}{l}\text { Volume 109, } \\
\text { 2017, } \\
\text { Pages 186- } \\
195\end{array}$ & $\begin{array}{c}\text { Sustainability; Water; } \\
\text { Wastewater; LCA; } \\
\text { QMRA }\end{array}$ & $\begin{array}{l}\text { Estados } \\
\text { Unidos }\end{array}$ & Impacto & $\begin{array}{c}\text { Desenvolvimento } \\
\text { Sustentável }\end{array}$ & $\begin{array}{r}\text { Science } \\
\text { Direct }\end{array}$ \\
\hline $\begin{array}{c}\text { Energy } \\
\text { Conversion } \\
\text { and } \\
\text { Management }\end{array}$ & $\begin{array}{c}\text { Energy recovery } \\
\text { capacity evaluation } \\
\text { within innovative } \\
\text { biological wastewater } \\
\text { treatment process }\end{array}$ & $\begin{array}{c}\text { Piergrossi, V } \\
\text { (Piergrossi, } \\
\text { Valentina); De } \\
\text { Sanctis, M (De } \\
\text { Sanctis, Marco); } \\
\text { Chimienti, S } \\
\text { (Chimienti, } \\
\text { Silvia); Di laconi, } \\
\text { C (Di laconi, } \\
\text { Claudio) }\end{array}$ & $\begin{array}{c}\text { Volume: } 172 \\
\text { Páginas: } 529- \\
539\end{array}$ & $\begin{array}{l}\text { Thermal biochemical } \\
\text { energy recovery; } \\
\text { Sequencing batch } \\
\text { biofilter granular } \\
\text { reactor (SBBGR); solar } \\
\text { wastewater source } \\
\text { heat pump (SWWHP); } \\
\text { aerobic granular } \\
\text { sludge (AGS) }\end{array}$ & Itália & Tecnologia & $\begin{array}{c}\text { Eficiência na } \\
\text { recuperação } \\
\text { energética }\end{array}$ & $\begin{array}{l}\text { Web of } \\
\text { Science }\end{array}$ \\
\hline $\begin{array}{c}\text { Environmental } \\
\text { Management }\end{array}$ & $\begin{array}{c}\text { Wastewater } \\
\text { Treatment Energy } \\
\text { Recovery Potential } \\
\text { For Adaptation To } \\
\text { Global Change: An } \\
\text { Integrated } \\
\text { Assessment }\end{array}$ & $\begin{array}{l}\text { Breach, PA } \\
\text { (Breach, Patrick } \\
\text { A.); Simonovic, } \\
\text { SP (Simonovic, } \\
\text { Slobodan P.) }\end{array}$ & $\begin{array}{c}\text { Volume: } 61 \\
\text { Edição: } 4 \\
\text { Páginas: } 624- \\
636\end{array}$ & $\begin{array}{c}\text { Water resources; } \\
\text { Wastewater } \\
\text { treatment; Energy } \\
\text { recovery; Water } \\
\text { quality; System } \\
\text { dynamics }\end{array}$ & Canada & Gestão & Análise integrada & $\begin{array}{l}\text { Web of } \\
\text { Science }\end{array}$ \\
\hline $\begin{array}{c}\text { Water } \\
\text { Research }\end{array}$ & $\begin{array}{l}\text { An integrated AMBBR } \\
\text { and IFAS-SBR process } \\
\text { for municipal } \\
\text { wastewater } \\
\text { treatment towards } \\
\text { enhanced energy } \\
\text { recovery, reduced } \\
\text { energy consumption } \\
\text { and sludge } \\
\text { production }\end{array}$ & $\begin{array}{c}\text { Gu, J (Gu, Jun); } \\
\text { Xu, GJ (Xu, } \\
\text { Guangjing); Liu, Y } \\
\text { (Liu, Yu) }\end{array}$ & $\begin{array}{c}\text { Volume: } 110 \\
\text { Páginas: } 262- \\
269\end{array}$ & $\begin{array}{l}\text { A-B process; Dissolved } \\
\text { methane; Energy } \\
\text { recovery; Nitritation; } \\
\text { Denitritation }\end{array}$ & Singapura & Tecnologia & $\begin{array}{c}\text { Eficiência na } \\
\text { recuperação } \\
\text { energética }\end{array}$ & $\begin{array}{l}\text { Web of } \\
\text { Science }\end{array}$ \\
\hline
\end{tabular}




\begin{tabular}{|c|c|c|c|c|c|c|c|c|}
\hline Revista & Título do Artigo & Autor(es) & Referências & Palavras Chaves & $\begin{array}{l}\text { País de } \\
\text { Origem }\end{array}$ & Categoria & Subcategoria & Fonte \\
\hline $\begin{array}{l}\text { Bioresource } \\
\text { Technology }\end{array}$ & $\begin{array}{l}\text { Role of macrophyte } \\
\text { and effect of } \\
\text { supplementary } \\
\text { aeration in up-flow } \\
\text { constructed wetland- } \\
\text { microbial fuel cell for } \\
\text { simultaneous } \\
\text { wastewater } \\
\text { treatment } \\
\text { and energy recovery }\end{array}$ & $\begin{array}{l}\text { Oon, YL (Oon, } \\
\text { Yoong-Ling); } \\
\text { Ong, SA (Ong, } \\
\text { Soon-An); Ho, LN } \\
\text { (Ho, Li-Ngee); } \\
\text { Wong, YS (Wong, } \\
\text { Yee-Shian); } \\
\text { Dahalan, FA } \\
\text { (Dahalan, Farrah } \\
\text { Aini); Oon, YS } \\
\text { (Oon, Yoong- } \\
\text { Sin); Lehl, HK } \\
\text { (Lehl, Harvinder } \\
\text { Kaur); Thung, } \\
\text { WE (Thung, Wei- } \\
\text { Eng); Nordin, N } \\
\text { (Nordin, } \\
\text { Noradiba) }\end{array}$ & $\begin{array}{c}\text { Volume: } 224 \\
\text { Páginas: } 265- \\
275\end{array}$ & $\begin{array}{l}\text { Simultaneous organic } \\
\text { matter; nutrient } \\
\text { removal and } \\
\text { bioenergy recovery by } \\
\text { UFCW-MFC; } \\
\text { Supplementary } \\
\text { aeration contributed } \\
\text { to oxygenation of the } \\
\text { wetland matrix; } \\
\text { Aerated UFCW-MFC } \\
\text { out-performed } \\
\text { control reactor in } \\
\text { bioelectricity } \\
\text { generation; } \\
\text { Macrophyte } \\
\text { enhanced nitrification } \\
\text { and bioelectricity } \\
\text { generation; Oxygen } \\
\text { as terminal electron } \\
\text { acceptor for } \\
\text { bioelectricity } \\
\text { generation. }\end{array}$ & Malásia & Tecnologia & $\begin{array}{l}\text { Análises de } \\
\text { tecnologia }\end{array}$ & $\begin{array}{l}\text { Web of } \\
\text { Science }\end{array}$ \\
\hline $\begin{array}{l}\text { Applied } \\
\text { Energy }\end{array}$ & $\begin{array}{l}\text { Flexible and stable } \\
\text { heat energy recovery } \\
\text { from municipal } \\
\text { wastewater } \\
\text { treatment plants } \\
\text { using a fixed-inverter } \\
\text { hybrid heat pump } \\
\text { system }\end{array}$ & $\begin{array}{c}\text { Chae, KJ (Chae, } \\
\text { Kyu-Jung); Ren, } \\
\text { XG (Ren, } \\
\text { Xianghao) }\end{array}$ & $\begin{array}{c}\text { Volume: } 179 \\
\text { Páginas: } 565- \\
574\end{array}$ & $\begin{array}{c}\text { Energy self- } \\
\text { sufficiency; Heat } \\
\text { pump; Fixed-speed } \\
\text { compressor; Inverter- } \\
\text { scrolled compressor; } \\
\text { Sewage treatment } \\
\text { plant; Heat recovery }\end{array}$ & $\begin{array}{l}\text { Coréia do } \\
\text { Sul }\end{array}$ & Tecnologia & $\begin{array}{l}\text { Análises de } \\
\text { tecnologia }\end{array}$ & $\begin{array}{l}\text { Web of } \\
\text { Science }\end{array}$ \\
\hline $\begin{array}{c}\text { Energy } \\
\text { Conversion } \\
\text { and } \\
\text { Management }\end{array}$ & $\begin{array}{l}\text { Reliable energy } \\
\text { recovery in an } \\
\text { existing municipal } \\
\text { wastewater } \\
\text { treatment plant with } \\
\text { a flow-variable micro- } \\
\text { hydropower system }\end{array}$ & $\begin{array}{l}\text { Chae, KJ (Chae, } \\
\text { Kyu-Jung); Kim, } \\
\text { IS (Kim, In-Soo); } \\
\text { Ren, XH (Ren, } \\
\text { Xianghao); } \\
\text { Cheon, KH } \\
\text { (Cheon, Kyeong- } \\
\text { Ho) }\end{array}$ & $\begin{array}{c}\text { Volume: } 101 \\
\text { Páginas: } 681- \\
688\end{array}$ & $\begin{array}{l}\text { Energy independence; } \\
\text { Micro-hydropower; } \\
\text { Small-hydropower; } \\
\text { Semi-Kaplan turbine; } \\
\text { Sewage treatment } \\
\text { plant; Variable pitch }\end{array}$ & $\begin{array}{l}\text { Coréia do } \\
\text { Sul }\end{array}$ & Tecnologia & $\begin{array}{l}\text { Análises de } \\
\text { tecnologia }\end{array}$ & $\begin{array}{l}\text { Web of } \\
\text { Science }\end{array}$ \\
\hline
\end{tabular}




\section{APÊNDICE B}

Questionário semi-estruturado aplicado

Fonte: Elaborado pela própria autora 
Questionário semi-estruturado

1. Nome do município

2. Quem opera o sistema de água no município?

3. Quem opera o sistema de esgoto no município?

4. Possui Agencia Reguladora para saneamento básico?

5. Possui coleta e tratamento de esgoto coletiva ou tudo funciona com fossa séptica?

6. Qual percentual do município tem coleta? E tratamento de esgoto?

7. Possui ETE do município ou em Residenciais/ Loteamentos?

8. Qual o nome da (s) ETE(s)/ Residencial? Minha Casa, Minha Vida ou Privado?

9. Possui endereço da ETE? Se houver, inserir.

10. Qual é o tipo de ETE, se houver?

11. O que é feito com o esgoto tratado?

12. O biogás produzido na ETE é queimado ou utilizado para alguma função?

13. O lodo da lagoa ou do reator passa por algum tratamento? Se sim, qual?

14. Nome e função de quem respondeu às perguntas.

15. Contato de quem respondeu às perguntas - Telefone com DDD, e email (se houver)

16. Observações 


\section{APÊNDICE C}

Dados dos municípios do Estado do Maranhão

Fonte: Adaptado de ANA, 2017; SNIS, 2018 


\begin{tabular}{|c|c|c|c|c|c|c|c|c|c|c|c|c|c|}
\hline \multirow[b]{2}{*}{ Município } & \multirow[b]{2}{*}{$\begin{array}{l}\text { Prestador de } \\
\text { Servicico de } \\
\text { Esgotamento } \\
\text { Sanitário }\end{array}$} & \multirow[b]{2}{*}{$\begin{array}{c}\text { População } \\
\text { Estimada } \\
2018 \\
\text { (IBGE,20 } \\
18 \text { ) }\end{array}$} & \multirow[b]{2}{*}{$\begin{array}{c}\text { Densida } \\
\text { de } \\
\text { Demogr } \\
\text { áfica } \\
\text { (IBGE,2 } \\
010 \text { ) }\end{array}$} & \multirow[b]{2}{*}{$\begin{array}{l}\text { PIB per capita } \\
\text { (IBGE,2010) }\end{array}$} & \multirow[b]{2}{*}{$\begin{array}{c}\text { IDHM } \\
\text { (PNUD, } \\
2010)\end{array}$} & \multirow[b]{2}{*}{$\begin{array}{c}\text { Í́ndice de } \\
\text { Atendimento } \\
\text { por Solução } \\
\text { Individual } \\
\text { (ANA, 2017) } \\
\text { *Solucôoes a } \\
\text { nível } \\
\text { doméstico, } \\
\text { como valas } \\
\text { de } \\
\text { infiltração, } \\
\text { fossa neggra e } \\
\text { fossa séptica }\end{array}$} & \multirow[b]{2}{*}{$\begin{array}{c}\text { Índice de } \\
\text { Atendimento } \\
\text { por Solução } \\
\text { Coletiva } \\
\text { (ANA, 2017; } \\
\text { SNIS, 2018) } \\
\text { *'Soluções a } \\
\text { nível municipal } \\
\text { ou em } \\
\text { condomínios }\end{array}$} & \multirow[b]{2}{*}{$\begin{array}{c}\text { Vazão } \\
\text { estimada de } \\
\text { esgoto } \\
\text { doméstico } \\
\text { (L/s) } \\
(\sim 130 \mathrm{~L} / \mathrm{d} \text {.ha } \\
\text { b) }\end{array}$} & \multicolumn{5}{|c|}{ Levantamento } \\
\hline & & & & & & & & & $\begin{array}{c}\text { Índice de } \\
\text { Atendimento } \\
\text { - Solução } \\
\text { Individual } \\
\text { *Soluções a } \\
\text { nível } \\
\text { doméstico, } \\
\text { como valas } \\
\text { de } \\
\text { infilttração, } \\
\text { fossa negra e } \\
\text { fossa séptica }\end{array}$ & $\begin{array}{c}\text { Índice de } \\
\text { Atendimento } \\
\text { - Solucacao } \\
\text { Coletiva } \\
\text { *Soluções a } \\
\text { nível } \\
\text { municipal ou } \\
\text { em } \\
\text { condomínios }\end{array}$ & $\begin{array}{l}\mathrm{N}^{\circ} \mathrm{de} \\
\text { ETEs }\end{array}$ & Grupo & $\begin{array}{c}\text { PMSB } \\
\text { aprovado }\end{array}$ \\
\hline Açailândia & PM & 111.757 & 17,92 & $\mathrm{R} \$ 18.088,00$ & 0,672 & $13,01 \%$ & $0,00 \%$ & 168,2 & $100,0 \%$ & $0,0 \%$ & & 2 & Sim \\
\hline Afonso Cunha & PM & 6.469 & 15,90 & R\$ $5.522,00$ & 0,529 & $0,12 \%$ & $0,00 \%$ & 9,7 & $100,0 \%$ & $0,0 \%$ & & 3 & Não \\
\hline Água Doce do Maranhão & PM & 12.488 & 26,13 & $\mathrm{R} \$ \quad 5.929,00$ & 0,500 & $0,86 \%$ & $0,00 \%$ & 18,8 & $100,0 \%$ & $0,0 \%$ & & 3 & Não \\
\hline Alcântara & PM & 22.083 & 14,70 & $\mathrm{R} \$ \quad 5.423,00$ & 0,573 & $8,42 \%$ & $0,00 \%$ & 33,2 & $100,0 \%$ & $0,0 \%$ & & 3 & Não \\
\hline Alto Alegre do Maranhão & PM & 26.839 & 64,18 & $\mathrm{R} \$ \quad 8.153,00$ & 0,554 & $22,91 \%$ & $0,00 \%$ & 40,4 & $100,0 \%$ & $0,0 \%$ & & 3 & Não \\
\hline Alto Alegre do Pindaré & PM & 31.894 & 16,07 & $5.611,00$ & 0,558 & $12,02 \%$ & $0,00 \%$ & 48,0 & $100,0 \%$ & $0,0 \%$ & & 3 & Não \\
\hline Alto Parnaíba & PM & 11.168 & 0,97 & $\mathrm{R} \$ 16.837,00$ & 0,633 & $1,91 \%$ & $10,69 \%$ & 16,8 & $60,0 \%$ & $40,0 \%$ & 2 & 1 & Não \\
\hline Amapá do Maranhão & PM & 6.918 & 12,80 & $\mathrm{R} \$ \quad 7.109,00$ & 0,520 & $31,61 \%$ & $93,00 \%$ & 10,4 & $100,0 \%$ & $0,0 \%$ & & 3 & Não \\
\hline Amarante do Maranhão & PM & 41.136 & 5,10 & R\$ $\quad 6.998,00$ & 0,555 & $8,84 \%$ & $0,00 \%$ & 61,9 & $100,0 \%$ & $0,0 \%$ & & 3 & Não \\
\hline Anajatuba & PM & 26.614 & 25,01 & R\$ $\quad 6.404,00$ & 0,581 & $18,39 \%$ & $0,00 \%$ & 40,0 & $100,0 \%$ & $0,0 \%$ & & 3 & Não \\
\hline
\end{tabular}




\begin{tabular}{|c|c|c|c|c|c|c|c|c|c|c|c|c|c|c|}
\hline \multirow[b]{2}{*}{ Município } & \multirow[b]{2}{*}{$\begin{array}{l}\text { Prestador de } \\
\text { Serviço de } \\
\text { Esgotamento } \\
\text { Sanitário }\end{array}$} & \multirow[b]{2}{*}{$\begin{array}{c}\text { População } \\
\text { Estimada } \\
2018 \\
\text { (IBGE,20 } \\
18 \text { ) }\end{array}$} & \multirow[b]{2}{*}{$\begin{array}{c}\text { Densida } \\
\text { de } \\
\text { Demogr } \\
\text { áfica } \\
\text { (IBGE,2 } \\
010)\end{array}$} & \multirow{2}{*}{\multicolumn{2}{|c|}{$\begin{array}{l}\text { PIB per capita } \\
\text { (IBGE,2010) }\end{array}$}} & \multirow[b]{2}{*}{$\begin{array}{l}\text { IDHM } \\
\text { (PNUD, } \\
2010 \text { ) }\end{array}$} & \multirow[b]{2}{*}{$\begin{array}{c}\text { Índice de } \\
\text { Atendimento } \\
\text { por Solução } \\
\text { Individual } \\
\text { (ANA, 2017) } \\
\text { *Soluções a } \\
\text { nível } \\
\text { doméstico, } \\
\text { como valas } \\
\text { de } \\
\text { infiltração, } \\
\text { fossa negra e } \\
\text { fossa séptica }\end{array}$} & \multirow[b]{2}{*}{$\begin{array}{c}\text { Índice de } \\
\text { Atendimento } \\
\text { por Solução } \\
\text { Coletiva } \\
\text { (ANA, 2017; } \\
\text { SNIS, 2018) } \\
\text { *Soluções a } \\
\text { nível municipal } \\
\text { ou em } \\
\text { condomínios }\end{array}$} & \multirow[b]{2}{*}{$\begin{array}{c}\text { Vazão } \\
\text { estimada de } \\
\text { esgoto } \\
\text { doméstico } \\
\text { (L/s) } \\
(\sim 130 \mathrm{~L} / \mathrm{d} . \mathrm{ha} \\
\text { b) }\end{array}$} & \multicolumn{5}{|c|}{ Levantamento } \\
\hline & & & & & & & & & & $\begin{array}{c}\text { Índice de } \\
\text { Atendimento } \\
\text { - Solução } \\
\text { Individual } \\
\text { *Soluções a } \\
\text { nível } \\
\text { doméstico, } \\
\text { como valas } \\
\text { de } \\
\text { infiltração, } \\
\text { fossa negra e } \\
\text { fossa séptica }\end{array}$ & $\begin{array}{c}\text { Índice de } \\
\text { Atendimento } \\
\text { - Solução } \\
\text { Coletiva } \\
\text { *Soluções a } \\
\text { nível } \\
\text { municipal ou } \\
\text { em } \\
\text { condomínios }\end{array}$ & $\begin{array}{l}\mathrm{N}^{o} \mathrm{de} \\
\text { ETEs }\end{array}$ & Grupo & $\begin{array}{l}\text { PMSB } \\
\text { aprovado }\end{array}$ \\
\hline Anapurus & PM & 15.566 & 22,91 & & $8.618,00$ & 0,581 & $6,83 \%$ & $0,00 \%$ & 23,4 & $100,0 \%$ & $0,0 \%$ & & 3 & Não \\
\hline Apicum-Açu & PM & 17.063 & 42,36 & $\mathrm{R} \$$ & $5.709,00$ & 0,568 & $1,18 \%$ & $0,00 \%$ & 25,7 & $100,0 \%$ & $0,0 \%$ & & 3 & Não \\
\hline Araguanã & PM & 15.297 & 17,35 & $\mathrm{R} \$$ & $5.091,00$ & 0,533 & $11,18 \%$ & $0,00 \%$ & 23,0 & $100,0 \%$ & $0,0 \%$ & & 3 & Não \\
\hline Araioses & PM & 46.103 & 23,84 & $\mathrm{R} \$$ & $5.672,00$ & 0,521 & $27,11 \%$ & $0,00 \%$ & 69,4 & $100,0 \%$ & $0,0 \%$ & & 3 & Não \\
\hline Arame & PM & 32.637 & 10,54 & $\mathrm{R} \$$ & $6.929,00$ & 0,512 & $13,64 \%$ & $0,00 \%$ & 49,1 & $100 \%$ & $0,0 \%$ & & 3 & Não \\
\hline Arari & PM & 29.764 & 25,89 & $\mathrm{R} \$$ & $8.014,00$ & 0,626 & $66,46 \%$ & $0,00 \%$ & 44,8 & $100,0 \%$ & $0,0 \%$ & & 2 & Não \\
\hline Axixá & PM & 12.076 & 56,15 & $\mathrm{R} \$$ & $5.873,00$ & 0,641 & $35,51 \%$ & $0,00 \%$ & 18,2 & $100,0 \%$ & $0,0 \%$ & & 2 & Não \\
\hline Bacabal & SAAE & 104.633 & 59,42 & $\mathrm{R} \$$ & $10.949,00$ & 0,651 & $95,00 \%$ & $0,00 \%$ & 157,4 & $85,0 \%$ & $15,0 \%$ & 1 & 2 & Não \\
\hline Bacabeira & PM & 16.855 & 24,25 & $\mathrm{R} \$$ & $20.480,00$ & 0,629 & $57,07 \%$ & $0,00 \%$ & 25,4 & $100,0 \%$ & $0,0 \%$ & & 2 & Não \\
\hline Bacuri & PM & 18.508 & 21,08 & $\mathrm{R} \$$ & $5.489,00$ & 0,578 & $18,20 \%$ & $0,00 \%$ & 27,8 & $100,00 \%$ & $0,0 \%$ & & 3 & Não \\
\hline Bacurituba & PM & 5.617 & 7,85 & $\mathrm{R} \$$ & $6.047,00$ & 0,537 & $0,00 \%$ & $0,00 \%$ & 8,5 & $100,0 \%$ & $0,0 \%$ & & 3 & Não \\
\hline Balsas & SAAE & 93.826 & 6,36 & $\mathrm{R} \$$ & $25.592,00$ & 0,687 & $19,76 \%$ & $0,00 \%$ & 141,2 & $100,0 \%$ & $0,0 \%$ & & 2 & Não \\
\hline
\end{tabular}




\begin{tabular}{|c|c|c|c|c|c|c|c|c|c|c|c|c|c|}
\hline \multirow[b]{2}{*}{ Município } & \multirow[b]{2}{*}{$\begin{array}{l}\text { Prestador de } \\
\text { Servicico de } \\
\text { Esgotamento } \\
\text { Sanitário }\end{array}$} & \multirow[b]{2}{*}{$\begin{array}{c}\text { População } \\
\text { Estimada } \\
2018 \\
\text { (IBGE,20 } \\
18 \text { ) }\end{array}$} & \multirow[b]{2}{*}{$\begin{array}{c}\text { Densida } \\
\text { de } \\
\text { Demogr } \\
\text { áfica } \\
\text { (IBGE,2 } \\
010 \text { ) }\end{array}$} & \multirow[b]{2}{*}{$\begin{array}{l}\text { PIB per capita } \\
\text { (IBGE,2010) }\end{array}$} & \multirow[b]{2}{*}{$\begin{array}{c}\text { IDHM } \\
\text { (PNUD, } \\
2010)\end{array}$} & \multirow[b]{2}{*}{$\begin{array}{c}\text { Í́ndice de } \\
\text { Atendimento } \\
\text { por Solução } \\
\text { Individual } \\
\text { (ANA, 2017) } \\
\text { *Solucôoes a } \\
\text { nível } \\
\text { doméstico, } \\
\text { como valas } \\
\text { de } \\
\text { infiltração, } \\
\text { fossa neggra e } \\
\text { fossa séptica }\end{array}$} & \multirow[b]{2}{*}{$\begin{array}{c}\text { Índice de } \\
\text { Atendimento } \\
\text { por Solução } \\
\text { Coletiva } \\
\text { (ANA, 2017; } \\
\text { SNIS, 2018) } \\
\text { *Soluções a } \\
\text { nível municipal } \\
\text { ou em } \\
\text { condomínios }\end{array}$} & \multirow[b]{2}{*}{$\begin{array}{c}\text { Vazão } \\
\text { estimada de } \\
\text { esgoto } \\
\text { doméstico } \\
\text { (L/s) } \\
(\sim 130 \mathrm{~L} / \mathrm{d} \text {.ha } \\
\text { b) }\end{array}$} & \multicolumn{5}{|c|}{ Levantamento } \\
\hline & & & & & & & & & $\begin{array}{c}\text { Índice de } \\
\text { Atendimento } \\
\text { - Solução } \\
\text { Individual } \\
\text { *Soluções a } \\
\text { nível } \\
\text { doméstico, } \\
\text { como valas } \\
\text { de } \\
\text { infilttração, } \\
\text { fossa negra e } \\
\text { fossa séptica }\end{array}$ & $\begin{array}{c}\text { Índice de } \\
\text { Atendimento } \\
\text { - Solucacao } \\
\text { Coletiva } \\
\text { *Soluções a } \\
\text { nível } \\
\text { municipal ou } \\
\text { em } \\
\text { condomínios }\end{array}$ & $\begin{array}{l}\mathrm{N}^{\circ} \mathrm{de} \\
\text { ETEs }\end{array}$ & Grupo & $\begin{array}{c}\text { PMSB } \\
\text { aprovado }\end{array}$ \\
\hline Barão de Grajaú & PM & 18.714 & 7,94 & $\mathrm{R} \$ 12.471,00$ & 0,592 & $6,16 \%$ & $0,00 \%$ & 28,2 & $100,0 \%$ & $0,0 \%$ & & 2 & Sim \\
\hline Barra do Corda & PM & 87.794 & 15,92 & R\$ $\quad 6.942,00$ & 0,606 & $16,75 \%$ & $0,00 \%$ & 132,1 & $100,0 \%$ & $0,0 \%$ & & 2 & Não \\
\hline Barreirinhas & CAEMA & 61.828 & 17,65 & $7.284,00$ & 0,570 & $27,06 \%$ & $26,18 \%$ & 93,0 & $72 \%$ & $28,1 \%$ & 1 & 2 & $\operatorname{Sim}$ \\
\hline Bela Vista do Maranhão & PM & 11.138 & 47,17 & $\mathrm{R} \$ \quad 6.828,00$ & 0,554 & $1,64 \%$ & $0,00 \%$ & 16,8 & $100,0 \%$ & $0,0 \%$ & & 3 & Não \\
\hline Bequimão & SAAE & 21.260 & 26,46 & $\mathrm{R} \$ \quad 5.341,00$ & 0,601 & $5,99 \%$ & $0,00 \%$ & 32,0 & $100,0 \%$ & $0,0 \%$ & & 2 & Não \\
\hline Bernardo do Mearim & PM & 6.011 & 22,93 & R\$ $\quad 8.359,00$ & 0,604 & $34,72 \%$ & $0,00 \%$ & 9,0 & $100,0 \%$ & $0,0 \%$ & & 2 & Não \\
\hline Boa Vista do Gurupi & PM & 9.158 & 19,70 & $\mathrm{R} \$ \quad 6.113,00$ & 0,545 & $1,87 \%$ & $31,25 \%$ & 13,8 & $100,0 \%$ & $0,0 \%$ & & 3 & Não \\
\hline Bom Jardim & PM & 41.435 & 5,93 & R\$ $\quad 6.809,00$ & 0,538 & $3,20 \%$ & $0,00 \%$ & 62,3 & $100,0 \%$ & $0,0 \%$ & & 3 & Não \\
\hline Bom Jesus das Selvas & PM & 33.479 & 10,62 & $7.531,00$ & 0,558 & $27,48 \%$ & $0,00 \%$ & 50,4 & $100,0 \%$ & $0,0 \%$ & & 3 & Não \\
\hline Bom Lugar & PM & 16.148 & 33,23 & R\$ $\quad 5.409,00$ & 0,562 & $0,05 \%$ & $0,00 \%$ & 24,3 & $100,0 \%$ & $0,0 \%$ & & 3 & Não \\
\hline
\end{tabular}




\begin{tabular}{|c|c|c|c|c|c|c|c|c|c|c|c|c|c|}
\hline \multirow[b]{2}{*}{ Município } & \multirow[b]{2}{*}{$\begin{array}{l}\text { Prestador de } \\
\text { Servicico de } \\
\text { Esgotamento } \\
\text { Sanitário }\end{array}$} & \multirow[b]{2}{*}{$\begin{array}{c}\text { População } \\
\text { Estimada } \\
2018 \\
\text { (IBGE,20 } \\
18 \text { ) }\end{array}$} & \multirow[b]{2}{*}{$\begin{array}{c}\text { Densida } \\
\text { de } \\
\text { Demogr } \\
\text { áfica } \\
\text { (IBGE,2 } \\
010 \text { ) }\end{array}$} & \multirow[b]{2}{*}{$\begin{array}{l}\text { PIB per capita } \\
\text { (IBGE,2010) }\end{array}$} & \multirow[b]{2}{*}{$\begin{array}{c}\text { IDHM } \\
\text { (PNUD, } \\
2010)\end{array}$} & \multirow[b]{2}{*}{$\begin{array}{c}\text { Í́ndice de } \\
\text { Atendimento } \\
\text { por Solução } \\
\text { Individual } \\
\text { (ANA, 2017) } \\
\text { *Solucôoes a } \\
\text { nível } \\
\text { doméstico, } \\
\text { como valas } \\
\text { de } \\
\text { infiltração, } \\
\text { fossa neggra e } \\
\text { fossa séptica }\end{array}$} & \multirow[b]{2}{*}{$\begin{array}{c}\text { Índice de } \\
\text { Atendimento } \\
\text { por Solução } \\
\text { Coletiva } \\
\text { (ANA, 2017; } \\
\text { SNIS, 2018) } \\
\text { *'Soluções a } \\
\text { nível municipal } \\
\text { ou em } \\
\text { condomínios }\end{array}$} & \multirow[b]{2}{*}{$\begin{array}{c}\text { Vazão } \\
\text { estimada de } \\
\text { esgoto } \\
\text { doméstico } \\
\text { (L/s) } \\
(\sim 130 \mathrm{~L} / \mathrm{d} \text {.ha } \\
\text { b) }\end{array}$} & \multicolumn{5}{|c|}{ Levantamento } \\
\hline & & & & & & & & & $\begin{array}{c}\text { Índice de } \\
\text { Atendimento } \\
\text { - Solução } \\
\text { Individual } \\
\text { *Soluções a } \\
\text { nível } \\
\text { doméstico, } \\
\text { como valas } \\
\text { de } \\
\text { infilttração, } \\
\text { fossa negra e } \\
\text { fossa séptica }\end{array}$ & $\begin{array}{c}\text { Índice de } \\
\text { Atendimento } \\
\text { - Solucacao } \\
\text { Coletiva } \\
\text { *Soluções a } \\
\text { nível } \\
\text { municipal ou } \\
\text { em } \\
\text { condomínios }\end{array}$ & $\begin{array}{l}\mathrm{N}^{\circ} \mathrm{de} \\
\text { ETEs }\end{array}$ & Grupo & $\begin{array}{c}\text { PMSB } \\
\text { aprovado }\end{array}$ \\
\hline Brejo & PM & 36.139 & 31,04 & R\$ $6.393,00$ & 0,562 & $27,23 \%$ & $10,69 \%$ & 54,4 & $100,0 \%$ & $0,0 \%$ & & 3 & Não \\
\hline Brejo de Areia & PM & 9.367 & 5,26 & $\mathrm{R} \$ \quad 5.953,00$ & 0,519 & $0,00 \%$ & $0,00 \%$ & 14,1 & $100,0 \%$ & $0,0 \%$ & & 3 & Não \\
\hline Buriti & PM & 28.557 & 18,33 & $\mathrm{R} \$ \quad 5.812,00$ & 0,548 & $14,84 \%$ & $0,00 \%$ & 43,0 & $100,0 \%$ & $0,0 \%$ & & 3 & Não \\
\hline Cachoeira Grande & PM & 9.382 & 11,97 & R\$ $\quad 6.334,00$ & 0,537 & $4,38 \%$ & $1,08 \%$ & 14,1 & $100,0 \%$ & $0,0 \%$ & & 3 & Não \\
\hline Cajapió & PM & 11.136 & 11,66 & $4.689,00$ & 0,553 & $40,03 \%$ & $0,00 \%$ & 16,8 & $100,0 \%$ & $0,0 \%$ & & 3 & Não \\
\hline Cajari & PM & 19.307 & 27,70 & $\mathrm{R} \$ \quad 5.136,00$ & 0,523 & $0,65 \%$ & $0,00 \%$ & 29,0 & $100,0 \%$ & $0,0 \%$ & & 3 & Não \\
\hline Campestre do Maranhão & SAAE & 14.294 & 21,72 & $\mathrm{R} \$ 10.521,00$ & 0,652 & $0,81 \%$ & $0,00 \%$ & 21,5 & $100,0 \%$ & $0,0 \%$ & & 2 & Não \\
\hline Cândido Mendes & PM & 20.076 & 11,33 & $R \$ \quad 6.292,00$ & 0,561 & $26,54 \%$ & $0,00 \%$ & 30,2 & $100,0 \%$ & $0,0 \%$ & & 3 & Não \\
\hline Cantanhede & PM & 21.872 & 26,45 & $\mathrm{R} \$ \quad 5.636,00$ & 0,565 & $46,37 \%$ & $0,00 \%$ & 32,9 & $100,0 \%$ & $0,0 \%$ & & 3 & Não \\
\hline
\end{tabular}




\begin{tabular}{|c|c|c|c|c|c|c|c|c|c|c|c|c|c|}
\hline \multirow[b]{2}{*}{ Município } & \multirow[b]{2}{*}{$\begin{array}{l}\text { Prestador de } \\
\text { Serviço de } \\
\text { Esgotamento } \\
\text { Sanitário }\end{array}$} & \multirow[b]{2}{*}{$\begin{array}{c}\text { População } \\
\text { Estimada } \\
2018 \\
\text { (IBGE,20 } \\
18 \text { ) }\end{array}$} & \multirow[b]{2}{*}{$\begin{array}{c}\text { Densida } \\
\text { de } \\
\text { Demogr } \\
\text { áfica } \\
\text { (IBGE, } 2 \\
010)\end{array}$} & \multirow[b]{2}{*}{$\begin{array}{l}\text { PIB per capita } \\
\text { (IBGE,2010) }\end{array}$} & \multirow[b]{2}{*}{$\begin{array}{l}\text { IDHM } \\
\text { (PNUD, } \\
2010 \text { ) }\end{array}$} & \multirow[b]{2}{*}{$\begin{array}{c}\text { Índice de } \\
\text { Atendimento } \\
\text { por Solução } \\
\text { Individual } \\
\text { (ANA, 2017) } \\
\text { *Soluções a } \\
\text { nível } \\
\text { doméstico, } \\
\text { como valas } \\
\text { de } \\
\text { infiltração, } \\
\text { fossa negra e } \\
\text { fossa séptica }\end{array}$} & \multirow[b]{2}{*}{$\begin{array}{c}\text { Índice de } \\
\text { Atendimento } \\
\text { por Solução } \\
\text { Coletiva } \\
\text { (ANA, 2017; } \\
\text { SNIS, 2018) } \\
\text { *Soluções a } \\
\text { nível municipal } \\
\text { ou em } \\
\text { condomínios }\end{array}$} & \multirow[b]{2}{*}{$\begin{array}{c}\text { Vazão } \\
\text { estimada de } \\
\text { esgoto } \\
\text { doméstico } \\
\text { (L/s) } \\
(\sim 130 \mathrm{~L} / \mathrm{d} . h a \\
\text { b) }\end{array}$} & \multicolumn{5}{|c|}{ Levantamento } \\
\hline & & & & & & & & & $\begin{array}{c}\text { Índice de } \\
\text { Atendimento } \\
\text { - Solução } \\
\text { Individual } \\
\text { *Soluções a } \\
\text { nível } \\
\text { doméstico, } \\
\text { como valas } \\
\text { de } \\
\text { infiltração, } \\
\text { fossa negra e } \\
\text { fossa séptica }\end{array}$ & $\begin{array}{l}\text { Índice de } \\
\text { Atendimento } \\
\text { - Solução } \\
\text { Coletiva } \\
\text { *Soluções a } \\
\text { nível } \\
\text { municipal ou } \\
\text { em } \\
\text { condomínios }\end{array}$ & $\begin{array}{l}\mathrm{N}^{o} \mathrm{de} \\
\text { ETEs }\end{array}$ & Grupo & $\begin{array}{l}\text { PMSB } \\
\text { aprovado }\end{array}$ \\
\hline Capinzal do Norte & SAAE & 10.932 & 18,12 & $\mathrm{R} \$ 10.530,00$ & 0,537 & $8,81 \%$ & $0,00 \%$ & 16,4 & $100,0 \%$ & $0,0 \%$ & & 3 & Não \\
\hline Carolina & SAAE & 24.337 & 3,72 & $\mathrm{R} \$ 10.166,00$ & 0,634 & $90,00 \%$ & $0,00 \%$ & 36,6 & $88,0 \%$ & $12,0 \%$ & 2 & 2 & Não \\
\hline Carutapera & PM & 23.658 & 17,86 & $\mathrm{R} \$ \quad 6.971,00$ & 0,574 & $22,92 \%$ & $0,00 \%$ & 35,6 & $100,0 \%$ & $0,0 \%$ & & 3 & Não \\
\hline Caxias & SAAE & 164.224 & 30,12 & $\mathrm{R} \$ \quad 10.277,00$ & 0,624 & $95,00 \%$ & $5,00 \%$ & 247,1 & $85,0 \%$ & $15,0 \%$ & 3 & 2 & $\operatorname{Sim}$ \\
\hline Cedral & PM & 10.657 & 35,63 & $5.444,00$ & 0,605 & $0,21 \%$ & $0,00 \%$ & 16,0 & $100,0 \%$ & $0,0 \%$ & & 2 & Não \\
\hline Central do Maranhão & $\mathrm{PM}$ & 8.604 & 24,72 & $5.077,00$ & 0,585 & $3,65 \%$ & $0,00 \%$ & 12,9 & $100,0 \%$ & $0,0 \%$ & & 3 & Não \\
\hline Centro do Guilherme & PM & 13.243 & 11,70 & $5.307,00$ & 0,542 & $9,25 \%$ & $0,00 \%$ & 19,9 & $100,0 \%$ & $0,0 \%$ & & 3 & Não \\
\hline $\begin{array}{l}\text { Centro Novo do } \\
\text { Maranhão }\end{array}$ & PM & 21.399 & 2,13 & $6.762,00$ & 0,518 & $14,98 \%$ & $0,00 \%$ & 32,2 & $100,0 \%$ & $0,0 \%$ & & 3 & Não \\
\hline Chapadinha & PM & 79.145 & 22,59 & $8.366,00$ & 0,604 & $20,20 \%$ & $0,00 \%$ & 119,1 & $100,0 \%$ & $0,0 \%$ & & 2 & $\operatorname{Sim}$ \\
\hline Cidelândia & PM & 14.617 & 9,34 & $9.258,00$ & 0,600 & $0,48 \%$ & $0,00 \%$ & 22,0 & $100,0 \%$ & $0,0 \%$ & & 2 & Sim \\
\hline Codó & SAAE & 122.597 & 27,06 & $8.492,00$ & 0,595 & $60,00 \%$ & $40,00 \%$ & 184,5 & $55,0 \%$ & $45,0 \%$ & 1 & 1 & Sim \\
\hline Coelho Neto & PM & 49.246 & 47,92 & $7.738,00$ & 0,564 & $6,03 \%$ & $0,00 \%$ & 74,1 & $100,0 \%$ & $0,0 \%$ & & 3 & Sim \\
\hline Colinas & PM & 41.042 & 19,76 & $7.491,00$ & 0,596 & $5,38 \%$ & $0,00 \%$ & 61,8 & $100 \%$ & $0,0 \%$ & & 2 & Sim \\
\hline Conceição do Lago-Açu & PM & 16.072 & 19,69 & $6.726,00$ & 0,512 & $4,69 \%$ & $0,00 \%$ & 24,2 & $100,0 \%$ & $0,0 \%$ & & 3 & Não \\
\hline
\end{tabular}




\begin{tabular}{|c|c|c|c|c|c|c|c|c|c|c|c|c|c|}
\hline \multirow[b]{2}{*}{ Município } & \multirow[b]{2}{*}{$\begin{array}{l}\text { Prestador de } \\
\text { Serviço de } \\
\text { Esgotamento } \\
\text { Sanitário }\end{array}$} & \multirow[b]{2}{*}{$\begin{array}{c}\text { População } \\
\text { Estimada } \\
2018 \\
\text { (IBGE,20 } \\
18 \text { ) }\end{array}$} & \multirow[b]{2}{*}{$\begin{array}{c}\text { Densida } \\
\text { de } \\
\text { Demogr } \\
\text { áfica } \\
\text { (IBGE,2 } \\
010)\end{array}$} & \multirow[b]{2}{*}{$\begin{array}{l}\text { PIB per capita } \\
\text { (IBGE,2010) }\end{array}$} & \multirow[b]{2}{*}{$\begin{array}{l}\text { IDHM } \\
\text { (PNUD, } \\
2010)\end{array}$} & \multirow[b]{2}{*}{$\begin{array}{c}\text { Índice de } \\
\text { Atendimento } \\
\text { por Solução } \\
\text { Individual } \\
\text { (ANA, 2017) } \\
\text { *Soluções a } \\
\text { nível } \\
\text { doméstico, } \\
\text { como valas } \\
\text { de } \\
\text { infiltração, } \\
\text { fossa negra e } \\
\text { fossa séptica }\end{array}$} & \multirow[b]{2}{*}{ 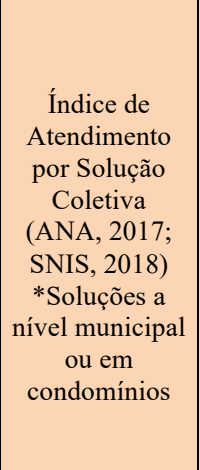 } & \multirow[b]{2}{*}{$\begin{array}{c}\text { Vazão } \\
\text { estimada de } \\
\text { esgoto } \\
\text { doméstico } \\
\text { (L/s) } \\
(\sim 130 \mathrm{~L} / \mathrm{d} . \mathrm{ha} \\
\text { b) }\end{array}$} & \multicolumn{5}{|c|}{ Levantamento } \\
\hline & & & & & & & & & $\begin{array}{c}\text { Índice de } \\
\text { Atendimento } \\
\text { - Solução } \\
\text { Individual } \\
\text { *Soluções a } \\
\text { nível } \\
\text { doméstico, } \\
\text { como valas } \\
\text { de } \\
\text { infiltração, } \\
\text { fossa negra e } \\
\text { fossa séptica }\end{array}$ & $\begin{array}{l}\text { Índice de } \\
\text { Atendimento } \\
\text { - Solução } \\
\text { Coletiva } \\
\text { *Soluções a } \\
\text { nível } \\
\text { municipal ou } \\
\text { em } \\
\text { condomínios }\end{array}$ & $\begin{array}{l}\mathrm{N}^{\circ} \text { de } \\
\text { ETEs }\end{array}$ & Grupo & $\begin{array}{l}\text { PMSB } \\
\text { aprovado }\end{array}$ \\
\hline Coroatá & CAEMA/PM & 65.044 & 27,27 & $\mathrm{R} \$ \quad 6.239,00$ & 0,576 & $21,89 \%$ & $6,24 \%$ & 97,9 & $94,0 \%$ & $5,9 \%$ & 1 & 3 & Não \\
\hline Cururupu & SAAE & 32.765 & 26,69 & $\mathrm{R} \$ \quad 6.548,00$ & 0,612 & $1,41 \%$ & $0,00 \%$ & 49,3 & $100,0 \%$ & $0,0 \%$ & & 2 & Não \\
\hline Davinópolis & PM & 12.901 & 37,44 & $\mathrm{R} \$ 56.656,00$ & 0,607 & $23,74 \%$ & $0,00 \%$ & 19,4 & $100,0 \%$ & $0,0 \%$ & & 2 & Sim \\
\hline Dom Pedro & PM & 23.328 & 63,27 & $\mathrm{R} \$ \quad 9.480,00$ & 0,622 & $10,07 \%$ & $0,00 \%$ & 35,1 & $100,0 \%$ & $0,0 \%$ & & 2 & Não \\
\hline Duque Bacelar & PM & 11.296 & 33,50 & $\mathrm{R} \$ \quad 5.776,00$ & 0,533 & $64,83 \%$ & $0,00 \%$ & 17,0 & $100,0 \%$ & $0,0 \%$ & & 3 & Não \\
\hline Esperantinópolis & PM & 17.379 & 38,37 & $7.828,00$ & 0,586 & $18,18 \%$ & $0,00 \%$ & 26,1 & $100,0 \%$ & $0,0 \%$ & & 3 & Não \\
\hline Estreito & PM & 41.355 & 13,18 & $\mathrm{R} \$ 16.605,00$ & 0,659 & $7,63 \%$ & $6,36 \%$ & 62,2 & $90,0 \%$ & $10,0 \%$ & 1 & 2 & Não \\
\hline Feira Nova do Maranhão & PM & 8.481 & 5,52 & $\mathrm{R} \$ \quad 8.045,00$ & 0,532 & $0,10 \%$ & $0,00 \%$ & 12,8 & $100,0 \%$ & $0,0 \%$ & & 3 & Não \\
\hline Fernando Falcão & PM & 10.258 & 1,82 & $5.121,00$ & 0,443 & $0,27 \%$ & $0,00 \%$ & 15,4 & $100,0 \%$ & $0,0 \%$ & & 3 & Não \\
\hline Formosa da Serra Negra & SAAE & 18.917 & 4,49 & $7.003,00$ & 0,556 & $2,77 \%$ & $0,00 \%$ & 28,5 & $100,0 \%$ & $0,0 \%$ & & 3 & Não \\
\hline Fortaleza dos Nogueiras & PM & 12.615 & 7,00 & $\mathrm{R} \$ \quad 10.324,00$ & 0,616 & $0,37 \%$ & $0,00 \%$ & 19,0 & $100,0 \%$ & $0,0 \%$ & & 2 & Não \\
\hline Fortuna & PM & 15.536 & 21,72 & $6.384,00$ & 0,580 & $4,11 \%$ & $0,00 \%$ & 23,4 & $100,0 \%$ & $0,0 \%$ & & 3 & Não \\
\hline Godofredo Viana & PM & 11.672 & 15,77 & $5.946,00$ & 0,604 & $31,82 \%$ & $0,00 \%$ & 17,6 & $100,0 \%$ & $0,0 \%$ & & 2 & Não \\
\hline
\end{tabular}




\begin{tabular}{|c|c|c|c|c|c|c|c|c|c|c|c|c|c|}
\hline \multirow[b]{2}{*}{ Município } & \multirow[b]{2}{*}{$\begin{array}{l}\text { Prestador de } \\
\text { Serviço de } \\
\text { Esgotamento } \\
\text { Sanitário }\end{array}$} & \multirow[b]{2}{*}{$\begin{array}{c}\text { População } \\
\text { Estimada } \\
2018 \\
\text { (IBGE,20 } \\
18 \text { ) }\end{array}$} & \multirow[b]{2}{*}{$\begin{array}{c}\text { Densida } \\
\text { de } \\
\text { Demogr } \\
\text { áfica } \\
\text { (IBGE,2 } \\
010)\end{array}$} & \multirow[b]{2}{*}{$\begin{array}{l}\text { PIB per capita } \\
\text { (IBGE,2010) }\end{array}$} & \multirow[b]{2}{*}{$\begin{array}{l}\text { IDHM } \\
\text { (PNUD, } \\
2010 \text { ) }\end{array}$} & \multirow[b]{2}{*}{$\begin{array}{c}\text { Índice de } \\
\text { Atendimento } \\
\text { por Solução } \\
\text { Individual } \\
\text { (ANA, 2017) } \\
\text { *Soluções a } \\
\text { nível } \\
\text { doméstico, } \\
\text { como valas } \\
\text { de } \\
\text { infiltração, } \\
\text { fossa negra e } \\
\text { fossa séptica }\end{array}$} & \multirow[b]{2}{*}{$\begin{array}{c}\text { Índice de } \\
\text { Atendimento } \\
\text { por Solução } \\
\text { Coletiva } \\
\text { (ANA, 2017; } \\
\text { SNIS, 2018) } \\
\text { *Soluções a } \\
\text { nível municipal } \\
\text { ou em } \\
\text { condomínios }\end{array}$} & \multirow[b]{2}{*}{$\begin{array}{c}\text { Vazão } \\
\text { estimada de } \\
\text { esgoto } \\
\text { doméstico } \\
\text { (L/s) } \\
(\sim 130 \mathrm{~L} / \mathrm{d} . \mathrm{ha} \\
\text { b) }\end{array}$} & \multicolumn{5}{|c|}{ Levantamento } \\
\hline & & & & & & & & & $\begin{array}{c}\text { Índice de } \\
\text { Atendimento } \\
\text { - Solução } \\
\text { Individual } \\
\text { *Soluções a } \\
\text { nível } \\
\text { doméstico, } \\
\text { como valas } \\
\text { de } \\
\text { infiltração, } \\
\text { fossa negra e } \\
\text { fossa séptica }\end{array}$ & $\begin{array}{l}\text { Índice de } \\
\text { Atendimento } \\
\text { - Solução } \\
\text { Coletiva } \\
\text { *Soluções a } \\
\text { nível } \\
\text { municipal ou } \\
\text { em } \\
\text { condomínios }\end{array}$ & $\begin{array}{l}\mathrm{N}^{o} \mathrm{de} \\
\text { ETEs }\end{array}$ & Grupo & $\begin{array}{l}\text { PMSB } \\
\text { aprovado }\end{array}$ \\
\hline Gonçalves Dias & PM & 17.924 & 19,90 & $\mathrm{R} \$ \quad 6.300,00$ & 0,568 & $5,28 \%$ & $0,00 \%$ & 27,0 & $100,0 \%$ & $0,0 \%$ & & 3 & Não \\
\hline Governador Archer & PM & 10.793 & 22,63 & $\mathrm{R} \$ \quad 6.721,00$ & 0,565 & $8,72 \%$ & $0,00 \%$ & 16,2 & $100,0 \%$ & $0,0 \%$ & & 3 & Não \\
\hline $\begin{array}{l}\text { Governador Edison } \\
\text { Lobão }\end{array}$ & SAAE & 18.068 & 25,81 & $\mathrm{R} \$ \quad 17.227,00$ & 0,629 & $18,30 \%$ & $0,00 \%$ & 27,2 & $100,0 \%$ & $0,0 \%$ & & 2 & Não \\
\hline $\begin{array}{c}\text { Governador Eugênio } \\
\text { Barros }\end{array}$ & PM & 16.772 & 19,57 & $5.671,00$ & 0,572 & $0,90 \%$ & $0,00 \%$ & 25,2 & $100,0 \%$ & $0,0 \%$ & & 3 & Não \\
\hline Governador Luiz Rocha & PM & 7.772 & 19,66 & $6.426,00$ & 0,544 & $16,73 \%$ & $0,00 \%$ & 11,7 & $100,0 \%$ & $0,0 \%$ & & 3 & Não \\
\hline $\begin{array}{c}\text { Governador Newton } \\
\text { Bello }\end{array}$ & PM & 10.211 & 10,27 & $6.207,00$ & 0,521 & $0,30 \%$ & $0,00 \%$ & 15,4 & $100,0 \%$ & $0,0 \%$ & & 3 & Não \\
\hline Governador Nunes Freire & PM & 25.616 & 24,49 & $7.529,00$ & 0,569 & $46,11 \%$ & $0,00 \%$ & 38,5 & $100,0 \%$ & $0,0 \%$ & & 3 & Não \\
\hline Graça Aranha & $\mathrm{PM}$ & 6.263 & 22,62 & $6.337,00$ & 0,570 & $0,21 \%$ & $0,00 \%$ & 9,4 & $100,0 \%$ & $0,0 \%$ & & 3 & Não \\
\hline Grajaú & SAAE & 68.876 & 7,03 & $8.310,00$ & 0,609 & $3,32 \%$ & $0,00 \%$ & 103,6 & $100,0 \%$ & $0,0 \%$ & & 2 & Não \\
\hline Guimarães & PM & 12.063 & 20,29 & $6.068,00$ & 0,625 & $0,62 \%$ & $0,00 \%$ & 18,2 & $100,0 \%$ & $0,0 \%$ & & 2 & Não \\
\hline Humberto de Campos & PM & 28.498 & 12,29 & $4.836,00$ & 0,535 & $16,07 \%$ & $0,00 \%$ & 42,9 & $100,0 \%$ & $0,0 \%$ & & 3 & Não \\
\hline
\end{tabular}




\begin{tabular}{|c|c|c|c|c|c|c|c|c|c|c|c|c|c|}
\hline \multirow[b]{2}{*}{ Município } & \multirow[b]{2}{*}{$\begin{array}{l}\text { Prestador de } \\
\text { Serviço de } \\
\text { Esgotamento } \\
\text { Sanitário }\end{array}$} & \multirow[b]{2}{*}{$\begin{array}{c}\text { População } \\
\text { Estimada } \\
2018 \\
\text { (IBGE,20 } \\
18 \text { ) }\end{array}$} & \multirow[b]{2}{*}{$\begin{array}{c}\text { Densida } \\
\text { de } \\
\text { Demogr } \\
\text { áfica } \\
\text { (IBGE,2 } \\
010)\end{array}$} & \multirow[b]{2}{*}{$\begin{array}{l}\text { PIB per capita } \\
\text { (IBGE,2010) }\end{array}$} & \multirow[b]{2}{*}{$\begin{array}{l}\text { IDHM } \\
\text { (PNUD, } \\
2010 \text { ) }\end{array}$} & \multirow[b]{2}{*}{$\begin{array}{c}\text { Índice de } \\
\text { Atendimento } \\
\text { por Solução } \\
\text { Individual } \\
\text { (ANA, 2017) } \\
\text { *Soluções a } \\
\text { nível } \\
\text { doméstico, } \\
\text { como valas } \\
\text { de } \\
\text { infiltração, } \\
\text { fossa negra e } \\
\text { fossa séptica }\end{array}$} & \multirow[b]{2}{*}{$\begin{array}{c}\text { Índice de } \\
\text { Atendimento } \\
\text { por Solução } \\
\text { Coletiva } \\
\text { (ANA, 2017; } \\
\text { SNIS, 2018) } \\
\text { *Soluções a } \\
\text { nível municipal } \\
\text { ou em } \\
\text { condomínios }\end{array}$} & \multirow[b]{2}{*}{$\begin{array}{c}\text { Vazão } \\
\text { estimada de } \\
\text { esgoto } \\
\text { doméstico } \\
\text { (L/s) } \\
(\sim 130 \mathrm{~L} / \mathrm{d} . \mathrm{ha} \\
\text { b) }\end{array}$} & \multicolumn{5}{|c|}{ Levantamento } \\
\hline & & & & & & & & & $\begin{array}{c}\text { Índice de } \\
\text { Atendimento } \\
\text { - Solução } \\
\text { Individual } \\
\text { *Soluções a } \\
\text { nível } \\
\text { doméstico, } \\
\text { como valas } \\
\text { de } \\
\text { infiltração, } \\
\text { fossa negra e } \\
\text { fossa séptica }\end{array}$ & $\begin{array}{c}\text { Índice de } \\
\text { Atendimento } \\
\text { - Solução } \\
\text { Coletiva } \\
\text { *Soluções a } \\
\text { nível } \\
\text { municipal ou } \\
\text { em } \\
\text { condomínios }\end{array}$ & $\begin{array}{l}\mathrm{N}^{o} \mathrm{de} \\
\text { ETEs }\end{array}$ & Grupo & $\begin{array}{l}\text { PMSB } \\
\text { aprovado }\end{array}$ \\
\hline Icatu & PM & 26.953 & 17,36 & $\mathrm{R} \$ \quad 5.079,00$ & 0,546 & $6,04 \%$ & $0,00 \%$ & 40,6 & $100,0 \%$ & $0,0 \%$ & & 3 & Não \\
\hline Igarapé do Meio & PM & 14.026 & 34,04 & $\mathrm{R} \$ \quad 11.243,00$ & 0,569 & $1,34 \%$ & $0,00 \%$ & 21,1 & $100 \%$ & $0,0 \%$ & & 3 & Não \\
\hline Igarapé Grande & PM & 11.252 & 29,50 & $\mathrm{R} \$ \quad 7.353,00$ & 0,614 & $6,90 \%$ & $0,00 \%$ & 16,9 & $100,0 \%$ & $0,0 \%$ & & 2 & Não \\
\hline Imperatriz & CAEMA & 258.016 & 180,79 & $\mathrm{R} \$ 27.483,00$ & 0,731 & $14,79 \%$ & $36,22 \%$ & 388,2 & $63,0 \%$ & $37,0 \%$ & 4 & 1 & Não \\
\hline Itaipava do Grajaú & PM & 15.897 & 11,54 & $\mathrm{R} \$ \quad 4.867,00$ & 0,518 & $3,19 \%$ & $0,00 \%$ & 23,9 & $100,0 \%$ & $0,0 \%$ & & 3 & Não \\
\hline Itapecuru Mirim & CAEMA/PM & 67.673 & 42,21 & $\mathrm{R} \$ \quad 8.215,00$ & 0,599 & $36,99 \%$ & $0,00 \%$ & 101,8 & $95,3 \%$ & $4,7 \%$ & 1 & 2 & Não \\
\hline Itinga do Maranhão & CAESI & 25.932 & 6,94 & $\mathrm{R} \$ \quad 10.563,00$ & 0,630 & $9,30 \%$ & $0,00 \%$ & 39,0 & $100,0 \%$ & $0,0 \%$ & & 2 & Sim \\
\hline Jatobá & $\mathrm{PM}$ & 9.993 & 14,42 & $\mathrm{R} \$ \quad 5.554,00$ & 0,561 & $53,18 \%$ & $0,70 \%$ & 15,0 & $100,0 \%$ & $0,0 \%$ & & 3 & Não \\
\hline Jenipapo dos Vieiras & $\mathrm{PM}$ & 16.432 & 7,87 & $5.346,00$ & 0,490 & $0,64 \%$ & $0,00 \%$ & 24,7 & $100,0 \%$ & $0,0 \%$ & & 3 & Não \\
\hline João Lisboa & PM & 23.696 & 32,00 & $8.692,00$ & 0,641 & $6,83 \%$ & $0,00 \%$ & 35,7 & $100,0 \%$ & $0,0 \%$ & & 2 & Não \\
\hline Joselândia & PM & 16.136 & 22,64 & $\mathrm{R} \$ \quad 6.080,00$ & 0,561 & $0,20 \%$ & $0,00 \%$ & 24,3 & $100,0 \%$ & $0,0 \%$ & & 3 & Não \\
\hline Junco do Maranhão & PM & 3.506 & 7,24 & $\mathrm{R} \$ \quad 11.766,00$ & 0,552 & $65,24 \%$ & $0,00 \%$ & 5,3 & $100,0 \%$ & $0,0 \%$ & & 3 & Não \\
\hline
\end{tabular}




\begin{tabular}{|c|c|c|c|c|c|c|c|c|c|c|c|c|c|}
\hline \multirow[b]{2}{*}{ Município } & \multirow[b]{2}{*}{$\begin{array}{l}\text { Prestador de } \\
\text { Serviço de } \\
\text { Esgotamento } \\
\text { Sanitário }\end{array}$} & \multirow[b]{2}{*}{$\begin{array}{c}\text { População } \\
\text { Estimada } \\
2018 \\
\text { (IBGE,20 } \\
18 \text { ) }\end{array}$} & \multirow[b]{2}{*}{$\begin{array}{c}\text { Densida } \\
\text { de } \\
\text { Demogr } \\
\text { áfica } \\
\text { (IBGE,2 } \\
010)\end{array}$} & \multirow[b]{2}{*}{$\begin{array}{l}\text { PIB per capita } \\
\text { (IBGE,2010) }\end{array}$} & \multirow[b]{2}{*}{$\begin{array}{l}\text { IDHM } \\
\text { (PNUD, } \\
2010 \text { ) }\end{array}$} & \multirow[b]{2}{*}{$\begin{array}{c}\text { Índice de } \\
\text { Atendimento } \\
\text { por Solução } \\
\text { Individual } \\
\text { (ANA, 2017) } \\
\text { *Soluções a } \\
\text { nível } \\
\text { doméstico, } \\
\text { como valas } \\
\text { de } \\
\text { infiltração, } \\
\text { fossa negra e } \\
\text { fossa séptica }\end{array}$} & \multirow[b]{2}{*}{$\begin{array}{c}\text { Índice de } \\
\text { Atendimento } \\
\text { por Solução } \\
\text { Coletiva } \\
\text { (ANA, 2017; } \\
\text { SNIS, 2018) } \\
\text { *Soluções a } \\
\text { nível municipal } \\
\text { ou em } \\
\text { condomínios }\end{array}$} & \multirow[b]{2}{*}{$\begin{array}{c}\text { Vazão } \\
\text { estimada de } \\
\text { esgoto } \\
\text { doméstico } \\
\text { (L/s) } \\
(\sim 130 \mathrm{~L} / \mathrm{d} . \mathrm{ha} \\
\text { b) }\end{array}$} & \multicolumn{5}{|c|}{ Levantamento } \\
\hline & & & & & & & & & $\begin{array}{c}\text { Índice de } \\
\text { Atendimento } \\
\text { - Solução } \\
\text { Individual } \\
\text { *Soluções a } \\
\text { nível } \\
\text { doméstico, } \\
\text { como valas } \\
\text { de } \\
\text { infiltração, } \\
\text { fossa negra e } \\
\text { fossa séptica }\end{array}$ & $\begin{array}{l}\text { Índice de } \\
\text { Atendimento } \\
\text { - Solução } \\
\text { Coletiva } \\
\text { *Soluções a } \\
\text { nível } \\
\text { municipal ou } \\
\text { em } \\
\text { condomínios }\end{array}$ & $\begin{array}{l}\mathrm{N}^{\circ} \mathrm{de} \\
\text { ETEs }\end{array}$ & Grupo & $\begin{array}{l}\text { PMSB } \\
\text { aprovado }\end{array}$ \\
\hline Lago da Pedra & PM & 49.911 & 37,68 & $\mathrm{R} \$ \quad 7.310,00$ & 0,589 & $13,52 \%$ & $0,00 \%$ & 75,1 & $100,0 \%$ & $0,0 \%$ & & 3 & Não \\
\hline Lago do Junco & $\mathrm{PM}$ & 10.808 & 34,72 & $\mathrm{R} \$ \quad 6.292,00$ & 0,581 & $25,91 \%$ & $0,00 \%$ & 16,3 & $100,0 \%$ & $0,0 \%$ & & 3 & Sim \\
\hline Lago dos Rodrigues & PM & 8.889 & 43,21 & $7.905,00$ & 0,602 & $0,70 \%$ & $0,00 \%$ & 13,4 & $100,0 \%$ & $0,0 \%$ & & 2 & Não \\
\hline Lago Verde & PM & 16.199 & 24,73 & R\$ $\quad 6.083,00$ & 0,557 & $18,41 \%$ & $0,00 \%$ & 24,4 & $100,0 \%$ & $0,0 \%$ & & 3 & Não \\
\hline Lagoa do Mato & PM & 11.235 & 6,48 & $\mathrm{R} \$ \quad 6.039,00$ & 0,566 & $2,04 \%$ & $0,00 \%$ & 16,9 & $100,0 \%$ & $0,0 \%$ & & 3 & Não \\
\hline $\begin{array}{l}\text { Lagoa Grande do } \\
\text { Maranhão }\end{array}$ & PM & 11.320 & 14,13 & $6.103,00$ & 0,502 & $2,49 \%$ & $0,00 \%$ & 17,0 & $100,0 \%$ & $0,0 \%$ & & 3 & Não \\
\hline Lajeado Novo & $\mathrm{PM}$ & 7.496 & 6,61 & $9.032,00$ & 0,589 & $10,83 \%$ & $100,00 \%$ & 11,3 & $100,0 \%$ & $0,0 \%$ & & 3 & Não \\
\hline Lima Campos & PM & 11.867 & 35,48 & $\mathrm{R} \$ 11.353,00$ & 0,581 & $1,56 \%$ & $0,00 \%$ & 17,9 & $100,0 \%$ & $0,0 \%$ & & 3 & Sim \\
\hline Loreto & $\mathrm{PM}$ & 12.098 & 3,17 & $9.695,00$ & 0,582 & $15,90 \%$ & $0,00 \%$ & 18,2 & $100,0 \%$ & $0,0 \%$ & & 3 & Não \\
\hline Luís Domingues & PM & 6.917 & 14,03 & $5.471,00$ & 0,588 & $38,45 \%$ & $0,00 \%$ & 10,4 & $100,0 \%$ & $0,0 \%$ & & 3 & Não \\
\hline
\end{tabular}




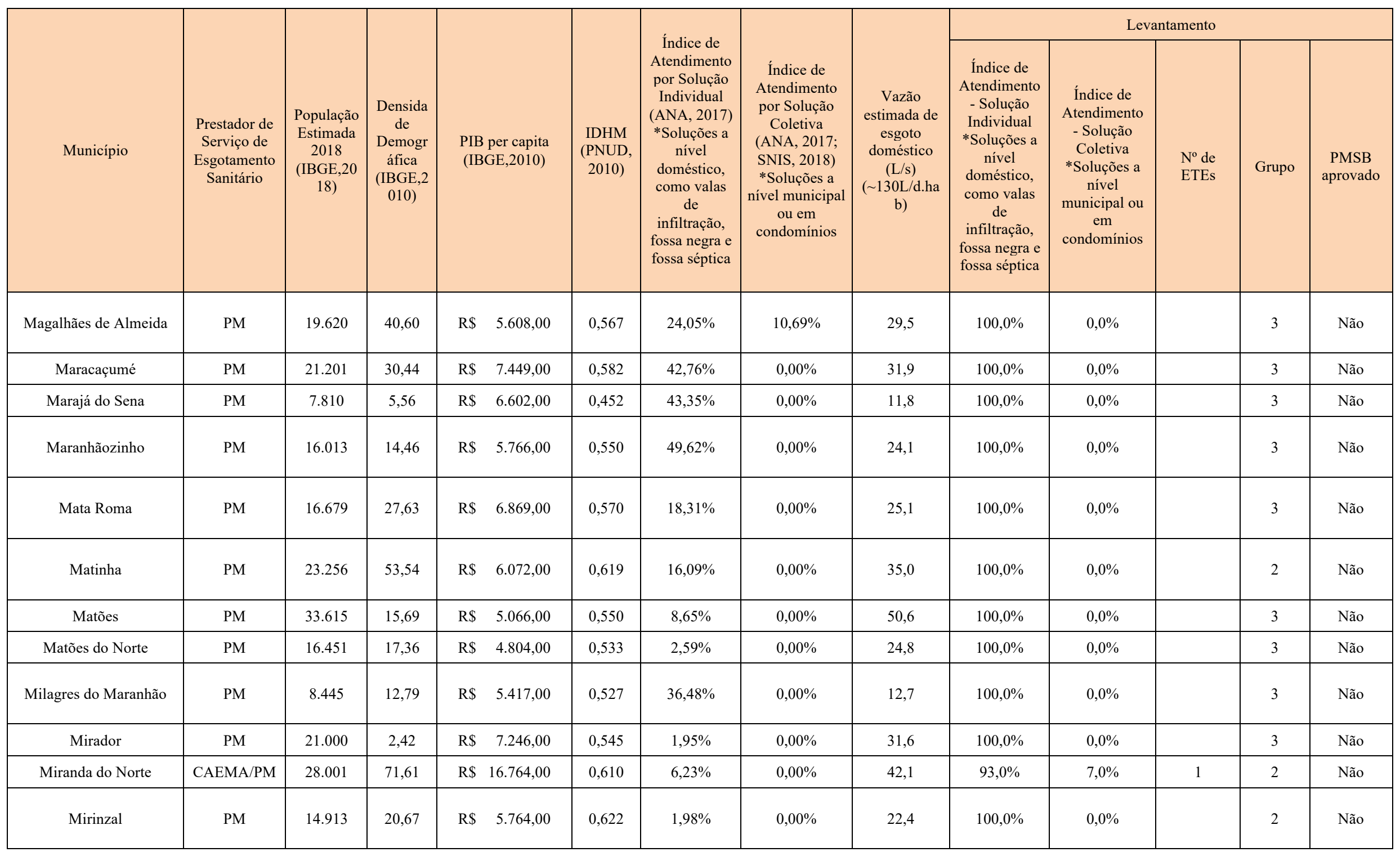




\begin{tabular}{|c|c|c|c|c|c|c|c|c|c|c|c|c|c|c|}
\hline \multirow[b]{2}{*}{ Município } & \multirow[b]{2}{*}{$\begin{array}{l}\text { Prestador de } \\
\text { Serviço de } \\
\text { Esgotamento } \\
\text { Sanitário }\end{array}$} & \multirow[b]{2}{*}{$\begin{array}{c}\text { População } \\
\text { Estimada } \\
2018 \\
\text { (IBGE,20 } \\
18 \text { ) }\end{array}$} & \multirow[b]{2}{*}{$\begin{array}{c}\text { Densida } \\
\text { de } \\
\text { Demogr } \\
\text { áfica } \\
\text { (IBGE,2 } \\
010)\end{array}$} & \multirow{2}{*}{\multicolumn{2}{|c|}{$\begin{array}{l}\text { PIB per capita } \\
\text { (IBGE,2010) }\end{array}$}} & \multirow[b]{2}{*}{$\begin{array}{l}\text { IDHM } \\
\text { (PNUD, } \\
2010 \text { ) }\end{array}$} & \multirow[b]{2}{*}{$\begin{array}{c}\text { Índice de } \\
\text { Atendimento } \\
\text { por Solução } \\
\text { Individual } \\
\text { (ANA, 2017) } \\
\text { *Soluções a } \\
\text { nível } \\
\text { doméstico, } \\
\text { como valas } \\
\text { de } \\
\text { infiltração, } \\
\text { fossa negra e } \\
\text { fossa séptica }\end{array}$} & \multirow[b]{2}{*}{$\begin{array}{c}\text { Índice de } \\
\text { Atendimento } \\
\text { por Solução } \\
\text { Coletiva } \\
\text { (ANA, 2017; } \\
\text { SNIS, 2018) } \\
\text { *Soluções a } \\
\text { nível municipal } \\
\text { ou em } \\
\text { condomínios }\end{array}$} & \multirow[b]{2}{*}{$\begin{array}{c}\text { Vazão } \\
\text { estimada de } \\
\text { esgoto } \\
\text { doméstico } \\
\text { (L/s) } \\
(\sim 130 \mathrm{~L} / \mathrm{d} \text {.ha } \\
\text { b) }\end{array}$} & \multicolumn{5}{|c|}{ Levantamento } \\
\hline & & & & & & & & & & $\begin{array}{c}\text { Índice de } \\
\text { Atendimento } \\
\text { - Solução } \\
\text { Individual } \\
\text { *Soluções a } \\
\text { nível } \\
\text { doméstico, } \\
\text { como valas } \\
\text { de } \\
\text { infiltração, } \\
\text { fossa negra e } \\
\text { fossa séptica }\end{array}$ & $\begin{array}{l}\text { Índice de } \\
\text { Atendimento } \\
\text { - Solução } \\
\text { Coletiva } \\
\text { *Soluções a } \\
\text { nível } \\
\text { municipal ou } \\
\text { em } \\
\text { condomínios }\end{array}$ & $\begin{array}{l}\mathrm{N}^{\circ} \text { de } \\
\text { ETEs }\end{array}$ & Grupo & $\begin{array}{l}\text { PMSB } \\
\text { aprovado }\end{array}$ \\
\hline Monção & PM & 33.201 & 24,38 & & $5.790,00$ & 0,546 & $6,85 \%$ & $0,00 \%$ & 50,0 & $100,0 \%$ & $0,0 \%$ & & 3 & Não \\
\hline Montes Altos & PM & 9.209 & 6,32 & $\mathrm{R} \$$ & $6.784,00$ & 0,575 & $8,95 \%$ & $0,00 \%$ & 13,9 & $100,0 \%$ & $0,0 \%$ & & 3 & Não \\
\hline Morros & PM & 19.292 & 10,37 & & $5.812,00$ & 0,548 & $2,32 \%$ & $0,00 \%$ & 29,0 & $100,0 \%$ & $0,0 \%$ & & 3 & Sim \\
\hline Nina Rodrigues & PM & 14.264 & 21,77 & $\mathrm{R} \$$ & $4.283,00$ & 0,585 & $6,08 \%$ & $0,00 \%$ & 21,5 & $100,0 \%$ & $0,0 \%$ & & 3 & Não \\
\hline Nova Colinas & PM & 5.340 & 6,57 & $\mathrm{R} \$$ & $9.017,00$ & 0,566 & $0,00 \%$ & $0,00 \%$ & 8,0 & $100,0 \%$ & $0,0 \%$ & & 3 & Não \\
\hline Nova Iorque & PM & 4.683 & 4,70 & $\mathrm{R} \$$ & $7.119,00$ & 0,584 & $18,39 \%$ & $0,00 \%$ & 7,0 & $100,0 \%$ & $0,0 \%$ & & 3 & Não \\
\hline $\begin{array}{l}\text { Nova Olinda do } \\
\text { Maranhão }\end{array}$ & PM & 20.774 & 7,80 & $\mathrm{R} \$$ & $6.260,00$ & 0,581 & $1,76 \%$ & $0,00 \%$ & 31,3 & $100,0 \%$ & $0,0 \%$ & & 3 & Não \\
\hline Olho D Água das Cunhãs & PM & 19.448 & 26,75 & $\mathrm{R} \$$ & $7.532,00$ & 0,589 & $10,32 \%$ & $0,00 \%$ & 29,3 & $100,0 \%$ & $0,0 \%$ & & 3 & Não \\
\hline $\begin{array}{l}\text { Olinda Nova do } \\
\text { Maranhão }\end{array}$ & PM & 14.563 & 66,69 & $\mathrm{R} \$$ & $6.259,00$ & 0,575 & $10,65 \%$ & $0,00 \%$ & 21,9 & $100,0 \%$ & $0,0 \%$ & & 3 & Não \\
\hline Paço do Lumiar & BRK & 120.621 & 842,63 & $\mathrm{R} \$$ & $6.672,00$ & 0,724 & $18,95 \%$ & $85,82 \%$ & 181,5 & $44,7 \%$ & $55,3 \%$ & 8 & 1 & Sim \\
\hline Palmeirândia & PM & 19.661 & 35,70 & $\mathrm{R} \$$ & $6.300,00$ & 0,556 & $0,29 \%$ & $0,00 \%$ & 29,6 & $100,0 \%$ & $0,0 \%$ & & 3 & Não \\
\hline Paraibano & PM & 21.290 & 37,89 & $\mathrm{R} \$$ & $6.441,00$ & 0,580 & $5,23 \%$ & $0,00 \%$ & 32,0 & $100,0 \%$ & $0,0 \%$ & & 3 & Não \\
\hline
\end{tabular}




\begin{tabular}{|c|c|c|c|c|c|c|c|c|c|c|c|c|c|c|}
\hline \multirow[b]{2}{*}{ Município } & \multirow[b]{2}{*}{$\begin{array}{l}\text { Prestador de } \\
\text { Serviço de } \\
\text { Esgotamento } \\
\text { Sanitário }\end{array}$} & \multirow[b]{2}{*}{$\begin{array}{c}\text { População } \\
\text { Estimada } \\
2018 \\
\text { (IBGE,20 } \\
18 \text { ) }\end{array}$} & \multirow[b]{2}{*}{$\begin{array}{c}\begin{array}{c}\text { Densida } \\
\text { de }\end{array} \\
\text { Demogr } \\
\text { áfica } \\
\text { (IBGE,2 } \\
010)\end{array}$} & \multirow{2}{*}{\multicolumn{2}{|c|}{$\begin{array}{l}\text { PIB per capita } \\
\text { (IBGE,2010) }\end{array}$}} & \multirow[b]{2}{*}{$\begin{array}{l}\text { IDHM } \\
\text { (PNUD, } \\
2010)\end{array}$} & \multirow[b]{2}{*}{$\begin{array}{c}\text { Índice de } \\
\text { Atendimento } \\
\text { por Solução } \\
\text { Individual } \\
\text { (ANA, 2017) } \\
\text { *Soluções a } \\
\text { nível } \\
\text { doméstico, } \\
\text { como valas } \\
\text { de } \\
\text { infiltração, } \\
\text { fossa negra e } \\
\text { fossa séptica }\end{array}$} & \multirow[b]{2}{*}{$\begin{array}{c}\text { Índice de } \\
\text { Atendimento } \\
\text { por Solução } \\
\text { Coletiva } \\
\text { (ANA, 2017; } \\
\text { SNIS, 2018) } \\
\text { *Soluções a } \\
\text { nível municipal } \\
\text { ou em } \\
\text { condomínios }\end{array}$} & \multirow[b]{2}{*}{$\begin{array}{c}\text { Vazão } \\
\text { estimada de } \\
\text { esgoto } \\
\text { doméstico } \\
\text { (L/s) } \\
(\sim 130 \mathrm{~L} / \mathrm{d} . \mathrm{ha} \\
\text { b) }\end{array}$} & \multicolumn{5}{|c|}{ Levantamento } \\
\hline & & & & & & & & & & $\begin{array}{c}\text { Índice de } \\
\text { Atendimento } \\
\text { - Solução } \\
\text { Individual } \\
\text { *Soluções a } \\
\text { nível } \\
\text { doméstico, } \\
\text { como valas } \\
\text { de } \\
\text { infiltração, } \\
\text { fossa negra e } \\
\text { fossa séptica }\end{array}$ & $\begin{array}{l}\text { Índice de } \\
\text { Atendimento } \\
\text { - Solução } \\
\text { Coletiva } \\
\text { *Soluções a } \\
\text { nível } \\
\text { municipal ou } \\
\text { em } \\
\text { condomínios }\end{array}$ & $\begin{array}{l}\mathrm{N}^{\circ} \text { de } \\
\text { ETEs }\end{array}$ & Grupo & $\begin{array}{l}\text { PMSB } \\
\text { aprovado }\end{array}$ \\
\hline Parnarama & PM & 34.805 & 10,06 & & $5.544,00$ & 0,542 & $0,67 \%$ & $0,00 \%$ & 52,4 & $0,0 \%$ & $100,0 \%$ & 1 & 3 & Não \\
\hline Passagem Franca & PM & 18.898 & 12,93 & & $6.579,00$ & 0,532 & $0,72 \%$ & $0,00 \%$ & 28,4 & $100,0 \%$ & $0,0 \%$ & & 3 & Não \\
\hline Pastos Bons & SAAE & 19.358 & 11,05 & & $8.239,00$ & 0,610 & $4,93 \%$ & $0,00 \%$ & 29,1 & $100,0 \%$ & $0,0 \%$ & & 2 & Não \\
\hline Paulino Neves & PM & 15.901 & 14,83 & & $6.429,00$ & 0,561 & $34,98 \%$ & $0,00 \%$ & 23,9 & $100,0 \%$ & $0,0 \%$ & & 3 & Não \\
\hline Paulo Ramos & PM & 21.015 & 19,06 & & $7.303,00$ & 0,549 & $0,39 \%$ & $0,00 \%$ & 31,6 & $100,0 \%$ & $0,0 \%$ & & 3 & Não \\
\hline Pedreiras & $\mathrm{PM}$ & 39.267 & 136,77 & $\mathrm{R} \$$ & $12.923,00$ & 0,682 & $24,97 \%$ & $0,00 \%$ & 59,1 & $100,0 \%$ & $0,0 \%$ & & 2 & Não \\
\hline Pedro do Rosário & PM & 24.930 & 12,99 & $\mathrm{R} \$$ & $5.628,00$ & 0,516 & $0,87 \%$ & $0,00 \%$ & 37,5 & $100,0 \%$ & $0,0 \%$ & & 3 & Não \\
\hline Penalva & PM & 38.203 & 46,42 & $\mathrm{R} \$$ & $4.530,00$ & 0,554 & $7,70 \%$ & $0,00 \%$ & 57,5 & $100,0 \%$ & $0,0 \%$ & & 3 & Não \\
\hline Peri Mirim & PM & 14.291 & 34,06 & $\mathrm{R} \$$ & $5.063,00$ & 0,599 & $22,14 \%$ & $0,00 \%$ & 21,5 & $100,0 \%$ & $0,0 \%$ & & 3 & Não \\
\hline Peritoró & PM & 23.025 & 25,71 & $\mathrm{R} \$$ & $7.529,00$ & 0,564 & $22,67 \%$ & $0,00 \%$ & 34,6 & $100,0 \%$ & $0,0 \%$ & & 3 & Não \\
\hline Pindaré-Mirim & PM & 32.815 & 127,25 & $\mathrm{R} \$$ & $9.765,00$ & 0,633 & $5,00 \%$ & $0,00 \%$ & 49,4 & $100,0 \%$ & $0,0 \%$ & & 2 & Não \\
\hline Pinheiro & CAEMA/PM & 82.990 & 51,66 & $\mathrm{R} \$$ & $9.721,00$ & 0,637 & $72,49 \%$ & $0,00 \%$ & 124,9 & $95,0 \%$ & $5,0 \%$ & 1 & 2 & Não \\
\hline Pio XII & PM & 21.594 & 40,39 & $\mathrm{R} \$$ & $7.588,00$ & 0,541 & $0,77 \%$ & $0,00 \%$ & 32,5 & $100,0 \%$ & $0,0 \%$ & & 3 & Não \\
\hline Pirapemas & PM & 18.527 & 25,24 & & $6.045,00$ & 0,576 & $18,24 \%$ & $0,00 \%$ & 27,9 & $100,0 \%$ & $0,0 \%$ & & 3 & Não \\
\hline
\end{tabular}




\begin{tabular}{|c|c|c|c|c|c|c|c|c|c|c|c|c|c|c|}
\hline \multirow[b]{2}{*}{ Município } & \multirow[b]{2}{*}{$\begin{array}{l}\text { Prestador de } \\
\text { Servicico de } \\
\text { Esgotamento } \\
\text { Sanitário }\end{array}$} & \multirow[b]{2}{*}{$\begin{array}{c}\text { População } \\
\text { Estimada } \\
2018 \\
\text { (IBGE,20 } \\
18 \text { ) }\end{array}$} & \multirow[b]{2}{*}{$\begin{array}{c}\text { Densida } \\
\text { de } \\
\text { Demogr } \\
\text { áfica } \\
\text { (IBGE,2 } \\
010 \text { ) }\end{array}$} & \multirow{2}{*}{\multicolumn{2}{|c|}{$\begin{array}{l}\text { PIB per capita } \\
\text { (IBGE,2010) }\end{array}$}} & \multirow[b]{2}{*}{$\begin{array}{c}\text { IDHM } \\
\text { (PNUD, } \\
\text { 2010) }\end{array}$} & \multirow[b]{2}{*}{$\begin{array}{c}\text { Índice de } \\
\text { Atendimento } \\
\text { por Solução } \\
\text { Individual } \\
\text { (ANA, 2017) } \\
\text { *Soluçôes a } \\
\text { nível } \\
\text { doméstico, } \\
\text { como valas } \\
\text { de } \\
\text { infiltração, } \\
\text { fossa negra e } \\
\text { fossa séptica }\end{array}$} & \multirow[b]{2}{*}{$\begin{array}{c}\text { Índice de } \\
\text { Atendimento } \\
\text { por Solução } \\
\text { Coletiva } \\
\text { (ANA, 2017; } \\
\text { SNIS, 2018) } \\
\text { *Soluçóes a } \\
\text { nível municipal } \\
\text { ou em } \\
\text { condomínios }\end{array}$} & \multirow[b]{2}{*}{$\begin{array}{c}\text { Vazão } \\
\text { estimada de } \\
\text { esgoto } \\
\text { doméstico } \\
\text { (L/s) } \\
(\sim 130 \mathrm{~L} / \text { d.ha } \\
\text { b) }\end{array}$} & \multicolumn{5}{|c|}{ Levantamento } \\
\hline & & & & & & & & & & $\begin{array}{c}\text { Índice de } \\
\text { Atendimento } \\
\text { - Solução } \\
\text { Individual } \\
\text { *Soluções a } \\
\text { nível } \\
\text { doméstico, } \\
\text { como valas } \\
\text { de } \\
\text { infilttração, } \\
\text { fossa negra e } \\
\text { fossa séptica }\end{array}$ & $\begin{array}{c}\text { Índice de } \\
\text { Atendimento } \\
\text { - Solucacao } \\
\text { Coletiva } \\
\text { *Soluções a } \\
\text { nível } \\
\text { municipal ou } \\
\text { em } \\
\text { condomínios }\end{array}$ & $\begin{array}{l}\mathrm{N}^{\circ} \mathrm{de} \\
\text { ETEs }\end{array}$ & Grupo & $\begin{array}{c}\text { PMSB } \\
\text { aprovado }\end{array}$ \\
\hline Poção de Pedras & PM & 18.157 & 20,13 & & $8.037,00$ & 0,576 & $13,14 \%$ & $0,00 \%$ & 27,3 & $100,0 \%$ & $0,0 \%$ & & 3 & Sim \\
\hline Porto Franco & PM & 23.675 & 15,19 & & $21.228,00$ & 0,684 & $1,94 \%$ & $0,00 \%$ & 35,6 & $100,0 \%$ & $0,0 \%$ & & 2 & Sim \\
\hline Porto Rico do Maranhão & PM & 5.995 & 28,31 & & $6.510,00$ & 0,615 & $35,67 \%$ & $0,00 \%$ & 9,0 & $100,0 \%$ & $0,0 \%$ & & 2 & Não \\
\hline Presidente Sarney & PM & 18.764 & 23,70 & & $7.666,00$ & 0,557 & $0,44 \%$ & $0,00 \%$ & 28,2 & $100,0 \%$ & $0,0 \%$ & & 3 & Não \\
\hline Presidente Vargas & PM & 11.124 & 23,33 & $\mathrm{R} \$$ & $5.074,00$ & 0,587 & $0,61 \%$ & $0,00 \%$ & 16,7 & $100,0 \%$ & $0,0 \%$ & & 3 & Não \\
\hline Primeira Cruz & PM & 15.197 & 10,20 & $\mathrm{R} \$$ & $5.001,00$ & 0,512 & $15,53 \%$ & $0,00 \%$ & 22,9 & $100,0 \%$ & $0,0 \%$ & & 3 & Não \\
\hline Raposa & SAAE & 30.337 & 409,10 & $\mathrm{R} \$$ & $6.943,00$ & 0,626 & $10,85 \%$ & $0,00 \%$ & 45,6 & $100,0 \%$ & $0,0 \%$ & & 2 & Sim \\
\hline Riachão & PM & 20.243 & 3,17 & & $10.912,00$ & 0,576 & $10,92 \%$ & $0,00 \%$ & 30,5 & $100,0 \%$ & $0,0 \%$ & & 3 & Não \\
\hline Ribamar Fiquene & PM & 7.755 & 9,75 & $\mathrm{R} \$$ & $9.350,00$ & 0,615 & $34,05 \%$ & $0,00 \%$ & 11,7 & $100,0 \%$ & $0,0 \%$ & & 2 & Não \\
\hline Rosário & PM & 42.482 & 57,77 & $\mathrm{R} \$$ & $7.289,00$ & 0,632 & $4,89 \%$ & $0,00 \%$ & 63,9 & $100,0 \%$ & $0,0 \%$ & & 2 & Não \\
\hline
\end{tabular}




\begin{tabular}{|c|c|c|c|c|c|c|c|c|c|c|c|c|c|}
\hline \multirow[b]{2}{*}{ Município } & \multirow[b]{2}{*}{$\begin{array}{l}\text { Prestador de } \\
\text { Serviço de } \\
\text { Esgotamento } \\
\text { Sanitário }\end{array}$} & \multirow[b]{2}{*}{$\begin{array}{c}\text { População } \\
\text { Estimada } \\
2018 \\
\text { (IBGE,20 } \\
18 \text { ) }\end{array}$} & \multirow[b]{2}{*}{$\begin{array}{c}\text { Densida } \\
\text { de } \\
\text { Demogr } \\
\text { áfica } \\
\text { (IBGE,2 } \\
010)\end{array}$} & \multirow[b]{2}{*}{$\begin{array}{l}\text { PIB per capita } \\
\text { (IBGE,2010) }\end{array}$} & \multirow[b]{2}{*}{$\begin{array}{c}\text { IDHM } \\
\text { (PNUD, } \\
2010 \text { ) }\end{array}$} & \multirow[b]{2}{*}{$\begin{array}{c}\text { Índice de } \\
\text { Atendimento } \\
\text { por Solução } \\
\text { Individual } \\
\text { (ANA, 2017) } \\
\text { *Soluções a } \\
\text { nível } \\
\text { doméstico, } \\
\text { como valas } \\
\text { de } \\
\text { infiltração, } \\
\text { fossa negra e } \\
\text { fossa séptica }\end{array}$} & \multirow[b]{2}{*}{$\begin{array}{c}\text { Índice de } \\
\text { Atendimento } \\
\text { por Solução } \\
\text { Coletiva } \\
\text { (ANA, 2017; } \\
\text { SNIS, 2018) } \\
\text { *Soluções a } \\
\text { nível municipal } \\
\text { ou em } \\
\text { condomínios }\end{array}$} & \multirow[b]{2}{*}{$\begin{array}{c}\text { Vazão } \\
\text { estimada de } \\
\text { esgoto } \\
\text { doméstico } \\
\text { (L/s) } \\
(\sim 130 \mathrm{~L} / \mathrm{d} . h a \\
\text { b) }\end{array}$} & \multicolumn{5}{|c|}{ Levantamento } \\
\hline & & & & & & & & & $\begin{array}{c}\text { Índice de } \\
\text { Atendimento } \\
\text { - Solução } \\
\text { Individual } \\
\text { *Soluções a } \\
\text { nível } \\
\text { doméstico, } \\
\text { como valas } \\
\text { de } \\
\text { infiltração, } \\
\text { fossa negra e } \\
\text { fossa séptica }\end{array}$ & $\begin{array}{l}\text { Índice de } \\
\text { Atendimento } \\
\text { - Solução } \\
\text { Coletiva } \\
\text { *Soluções a } \\
\text { nível } \\
\text { municipal ou } \\
\text { em } \\
\text { condomínios }\end{array}$ & $\begin{array}{l}\mathrm{N}^{o} \mathrm{de} \\
\text { ETEs }\end{array}$ & Grupo & $\begin{array}{l}\text { PMSB } \\
\text { aprovado }\end{array}$ \\
\hline Sambaíba & PM & 5.663 & 2,21 & $\mathrm{R} \$ 15.894,00$ & 0,565 & $23,20 \%$ & $0,00 \%$ & 8,5 & $100,0 \%$ & $0,0 \%$ & & 3 & Não \\
\hline $\begin{array}{l}\text { Santa Filomena do } \\
\text { Maranhão }\end{array}$ & PM & 7.719 & 11,72 & $\mathrm{R} \$ \quad 5.336,00$ & 0,525 & $11,95 \%$ & $0,00 \%$ & 11,6 & $100,0 \%$ & $0,0 \%$ & & 3 & Não \\
\hline Santa Helena & PM & 41.770 & 16,94 & $\mathrm{R} \$ \quad 6.284,00$ & 0,571 & $5,59 \%$ & $0,00 \%$ & 62,8 & $100,0 \%$ & $0,0 \%$ & & 3 & Não \\
\hline Santa Inês & PM & 88.590 & 188,49 & $\mathrm{R} \$ 14.691,00$ & 0,674 & $29,30 \%$ & $0,00 \%$ & 133,3 & $100,0 \%$ & $0,0 \%$ & & 2 & Não \\
\hline Santa Luzia & PM & 72.440 & 15,54 & $\mathrm{R} \$ \quad 7.851,00$ & 0,550 & $10,56 \%$ & $0,00 \%$ & 109,0 & $100,0 \%$ & $0,0 \%$ & & 3 & Não \\
\hline Santa Luzia do Paruá & $\mathrm{PM}$ & 25.134 & 25,24 & $\mathrm{R} \$ \quad 8.919,00$ & 0,599 & $20,80 \%$ & $0,00 \%$ & 37,8 & $100,0 \%$ & $0,0 \%$ & & 2 & Não \\
\hline $\begin{array}{l}\text { Santa Quitéria do } \\
\text { Maranhão }\end{array}$ & PM & 25.519 & 15,22 & $6.714,00$ & 0,555 & $4,04 \%$ & $10,69 \%$ & 38,4 & $100,0 \%$ & $0,0 \%$ & & 3 & Não \\
\hline Santa Rita & PM & 37.404 & 45,82 & $7.325,00$ & 0,609 & $17,37 \%$ & $0,00 \%$ & 56,3 & $100,0 \%$ & $0,0 \%$ & & 2 & Não \\
\hline Santana do Maranhão & PM & 13.223 & 12,51 & $4.587,00$ & 0,510 & $0,00 \%$ & $0,00 \%$ & 19,9 & $100,0 \%$ & $0,0 \%$ & & 3 & Não \\
\hline $\begin{array}{l}\text { Santo Amaro do } \\
\text { Maranhão }\end{array}$ & PM & 15.654 & 8,63 & $\mathrm{R} \$ \quad 4.884,00$ & 0,518 & $2,29 \%$ & $0,00 \%$ & 23,6 & $100,0 \%$ & $0,0 \%$ & & 3 & Não \\
\hline Santo Antônio dos Lopes & PM & 14.534 & 18,53 & $\mathrm{R} \$ 89.607,00$ & 0,566 & $2,34 \%$ & $0,00 \%$ & 21,9 & $100,0 \%$ & $0,0 \%$ & & 2 & Não \\
\hline $\begin{array}{l}\text { São Benedito do Rio } \\
\text { Preto }\end{array}$ & PM & 18.608 & 19,11 & $\mathrm{R} \$ \quad 5.684,00$ & 0,541 & $27,98 \%$ & $0,00 \%$ & 28,0 & $100,0 \%$ & $0,0 \%$ & & 3 & Não \\
\hline São Bento & PM & 44.811 & 88,74 & $9.578,00$ & 0,602 & $10,85 \%$ & $0,00 \%$ & 67,4 & $100,0 \%$ & $0,0 \%$ & & 2 & Não \\
\hline São Bernardo & PM & 28.343 & 26,29 & $9.427,00$ & 0,572 & $15,59 \%$ & $0,00 \%$ & 42,6 & $100,0 \%$ & $0,0 \%$ & & 3 & Não \\
\hline
\end{tabular}




\begin{tabular}{|c|c|c|c|c|c|c|c|c|c|c|c|c|c|}
\hline \multirow[b]{2}{*}{ Município } & \multirow[b]{2}{*}{$\begin{array}{l}\text { Prestador de } \\
\text { Serviço de } \\
\text { Esgotamento } \\
\text { Sanitário }\end{array}$} & \multirow[b]{2}{*}{$\begin{array}{c}\text { População } \\
\text { Estimada } \\
2018 \\
\text { (IBGE,20 } \\
18 \text { ) }\end{array}$} & \multirow[b]{2}{*}{$\begin{array}{c}\text { Densida } \\
\text { de } \\
\text { Demogr } \\
\text { áfica } \\
\text { (IBGE,2 } \\
010)\end{array}$} & \multirow[b]{2}{*}{$\begin{array}{l}\text { PIB per capita } \\
\text { (IBGE,2010) }\end{array}$} & \multirow[b]{2}{*}{$\begin{array}{c}\text { IDHM } \\
\text { (PNUD, } \\
2010 \text { ) }\end{array}$} & \multirow[b]{2}{*}{$\begin{array}{c}\text { Índice de } \\
\text { Atendimento } \\
\text { por Solução } \\
\text { Individual } \\
\text { (ANA, 2017) } \\
\text { *Soluções a } \\
\text { nível } \\
\text { doméstico, } \\
\text { como valas } \\
\text { de } \\
\text { infiltração, } \\
\text { fossa negra e } \\
\text { fossa séptica }\end{array}$} & \multirow[b]{2}{*}{$\begin{array}{c}\text { Índice de } \\
\text { Atendimento } \\
\text { por Solução } \\
\text { Coletiva } \\
\text { (ANA, 2017; } \\
\text { SNIS, 2018) } \\
\text { *Soluções a } \\
\text { nível municipal } \\
\text { ou em } \\
\text { condomínios }\end{array}$} & \multirow[b]{2}{*}{$\begin{array}{c}\text { Vazão } \\
\text { estimada de } \\
\text { esgoto } \\
\text { doméstico } \\
\text { (L/s) } \\
\text { ( 130L/d.ha } \\
\text { b) }\end{array}$} & \multicolumn{5}{|c|}{ Levantamento } \\
\hline & & & & & & & & & $\begin{array}{c}\text { Índice de } \\
\text { Atendimento } \\
\text { - Solução } \\
\text { Individual } \\
\text { *Soluções a } \\
\text { nível } \\
\text { doméstico, } \\
\text { como valas } \\
\text { de } \\
\text { infiltração, } \\
\text { fossa negra e } \\
\text { fossa séptica }\end{array}$ & $\begin{array}{l}\text { Índice de } \\
\text { Atendimento } \\
\text { - Solução } \\
\text { Coletiva } \\
\text { *Soluções a } \\
\text { nível } \\
\text { municipal ou } \\
\text { em } \\
\text { condomínios }\end{array}$ & $\begin{array}{l}\mathrm{N}^{o} \mathrm{de} \\
\text { ETEs }\end{array}$ & Grupo & $\begin{array}{l}\text { PMSB } \\
\text { aprovado }\end{array}$ \\
\hline $\begin{array}{l}\text { São Domingos do } \\
\text { Azeitão }\end{array}$ & PM & 7.363 & 7,27 & $\mathrm{R} \$ 15.214,00$ & 0,590 & $0,91 \%$ & $0,00 \%$ & 11,1 & $100,0 \%$ & $0,0 \%$ & & 2 & Não \\
\hline $\begin{array}{l}\text { São Domingos do } \\
\text { Maranhão }\end{array}$ & PM & 34.368 & 29,17 & $\mathrm{R} \$ \quad 7.698,00$ & 0,582 & $22,82 \%$ & $0,00 \%$ & 51,7 & $100,0 \%$ & $0,0 \%$ & & 3 & Não \\
\hline São Félix de Balsas & PM & 4.609 & 2,31 & $8.639,00$ & 0,557 & $1,17 \%$ & $0,00 \%$ & 6,9 & $100,0 \%$ & $0,0 \%$ & & 3 & Não \\
\hline São Francisco do Brejão & PM & 11.652 & 13,76 & $\mathrm{R} \$ \quad 8.229,00$ & 0,584 & $16,15 \%$ & $0,00 \%$ & 17,5 & $100,0 \%$ & $0,0 \%$ & & 3 & Não \\
\hline $\begin{array}{l}\text { São Francisco do } \\
\text { Maranhão }\end{array}$ & PM & 12.201 & 5,17 & $\mathrm{R} \$ \quad 5.135,00$ & 0,528 & $0,73 \%$ & $0,00 \%$ & 18,4 & $100,0 \%$ & $0,0 \%$ & & 3 & Não \\
\hline São João Batista & PM & 20.629 & 28,84 & $\mathrm{R} \$ \quad 5.783,00$ & 0,598 & $42,22 \%$ & $0,00 \%$ & 31,0 & $100,0 \%$ & $0,0 \%$ & & 3 & Não \\
\hline São João do Carú & PM & 15.828 & 19,99 & $\mathrm{R} \$ \quad 5.780,00$ & 0,509 & $0,27 \%$ & $0,00 \%$ & 23,8 & $100,0 \%$ & $0,0 \%$ & & 3 & Não \\
\hline São João do Paraíso & SAAE & 11.162 & 5,27 & $\mathrm{R} \$ 13.647,00$ & 0,609 & $4,97 \%$ & $0,00 \%$ & 16,8 & $100,0 \%$ & $0,0 \%$ & & 2 & Não \\
\hline São João do Soter & PM & 18.438 & 11,99 & $\mathrm{R} \$ \quad 5.198,00$ & 0,517 & $5,19 \%$ & $0,00 \%$ & 27,7 & $100,0 \%$ & $0,0 \%$ & & 3 & Não \\
\hline São João dos Patos & PM & 25.860 & 16,61 & $\mathrm{R} \$ 10.157,00$ & 0,615 & $1,19 \%$ & $0,00 \%$ & 38,9 & $100,0 \%$ & $0,0 \%$ & & 2 & Não \\
\hline São José de Ribamar & BRK & 176.321 & 419,82 & $\mathrm{R} \$ 10.808,00$ & 0,708 & $26,22 \%$ & $80,95 \%$ & 265,3 & $26,6 \%$ & $74,4 \%$ & 19 & 1 & Sim \\
\hline São José dos Basílios & PM & 7.642 & 20,67 & $\mathrm{R} \$ \quad 5.709,00$ & 0,557 & $0,13 \%$ & $0,00 \%$ & 11,5 & $100,0 \%$ & $0,0 \%$ & & 3 & Não \\
\hline São Luís & CAEMA & 1.094 .667 & $1.215,69$ & $\mathrm{R} \$ 26.154,00$ & 0,768 & $19,42 \%$ & $73,15 \%$ & 1647,1 & $80,2 \%$ & $19,8 \%$ & 16 & 1 & Sim \\
\hline $\begin{array}{c}\text { São Luís Gonzaga do } \\
\text { Maranhão }\end{array}$ & PM & 18.988 & 20,81 & $\mathrm{R} \$ \quad 6.997,00$ & 0,540 & $6,03 \%$ & $0,00 \%$ & 28,6 & $100,0 \%$ & $0,0 \%$ & & 3 & Não \\
\hline
\end{tabular}




\begin{tabular}{|c|c|c|c|c|c|c|c|c|c|c|c|c|c|}
\hline \multirow[b]{2}{*}{ Município } & \multirow[b]{2}{*}{$\begin{array}{l}\text { Prestador de } \\
\text { Serviço de } \\
\text { Esgotamento } \\
\text { Sanitário }\end{array}$} & \multirow[b]{2}{*}{$\begin{array}{c}\text { População } \\
\text { Estimada } \\
2018 \\
\text { (IBGE,20 } \\
18)\end{array}$} & \multirow[b]{2}{*}{$\begin{array}{c}\text { Densida } \\
\text { de } \\
\text { Demogr } \\
\text { áfica } \\
\text { (IBGE,2 } \\
010)\end{array}$} & \multirow[b]{2}{*}{$\begin{array}{l}\text { PIB per capita } \\
\text { (IBGE,2010) }\end{array}$} & \multirow[b]{2}{*}{$\begin{array}{l}\text { IDHM } \\
\text { (PNUD, } \\
2010 \text { ) }\end{array}$} & \multirow[b]{2}{*}{$\begin{array}{c}\text { Índice de } \\
\text { Atendimento } \\
\text { por Solução } \\
\text { Individual } \\
\text { (ANA, 2017) } \\
\text { *Soluções a } \\
\text { nível } \\
\text { doméstico, } \\
\text { como valas } \\
\text { de } \\
\text { infiltração, } \\
\text { fossa negra e } \\
\text { fossa séptica }\end{array}$} & \multirow[b]{2}{*}{$\begin{array}{c}\text { Índice de } \\
\text { Atendimento } \\
\text { por Solução } \\
\text { Coletiva } \\
\text { (ANA, 2017; } \\
\text { SNIS, 2018) } \\
\text { *Soluções a } \\
\text { nível municipal } \\
\text { ou em } \\
\text { condomínios }\end{array}$} & \multirow[b]{2}{*}{$\begin{array}{c}\text { Vazão } \\
\text { estimada de } \\
\text { esgoto } \\
\text { doméstico } \\
\text { (L/s) } \\
(\sim 130 \mathrm{~L} / \mathrm{d} . \mathrm{ha} \\
\text { b) }\end{array}$} & \multicolumn{5}{|c|}{ Levantamento } \\
\hline & & & & & & & & & $\begin{array}{c}\text { Índice de } \\
\text { Atendimento } \\
\text { - Solução } \\
\text { Individual } \\
\text { *Soluções a } \\
\text { nível } \\
\text { doméstico, } \\
\text { como valas } \\
\text { de } \\
\text { infiltração, } \\
\text { fossa negra e } \\
\text { fossa séptica }\end{array}$ & $\begin{array}{l}\text { Índice de } \\
\text { Atendimento } \\
\text { - Solução } \\
\text { Coletiva } \\
\text { *Soluções a } \\
\text { nível } \\
\text { municipal ou } \\
\text { em } \\
\text { condomínios }\end{array}$ & $\begin{array}{l}\mathrm{N}^{\circ} \text { de } \\
\text { ETEs }\end{array}$ & Grupo & $\begin{array}{l}\text { PMSB } \\
\text { aprovado }\end{array}$ \\
\hline São Mateus do Maranhão & PM & 41.350 & 49,91 & R\$ $7.494,00$ & 0,616 & $7,87 \%$ & $0,00 \%$ & 62,2 & $100,0 \%$ & $0,0 \%$ & & 2 & Não \\
\hline $\begin{array}{c}\text { São Pedro da Água } \\
\text { Branca }\end{array}$ & PM & 12.645 & 16,69 & $\mathrm{R} \$ \quad 7.082,00$ & 0,605 & $4,49 \%$ & $0,00 \%$ & 19,0 & $100,0 \%$ & $0,0 \%$ & & 2 & Não \\
\hline São Pedro dos Crentes & PM & 4.651 & 4,52 & $\mathrm{R} \$ 11.044,00$ & 0,600 & $0,37 \%$ & $0,00 \%$ & 7,0 & $100,0 \%$ & $0,0 \%$ & & 2 & Não \\
\hline $\begin{array}{l}\text { São Raimundo das } \\
\text { Mangabeiras }\end{array}$ & PM & 18.755 & 4,96 & $\mathrm{R} \$ 21.281,00$ & 0,610 & $7,14 \%$ & $0,00 \%$ & 28,2 & $100,0 \%$ & $0,0 \%$ & & 2 & Não \\
\hline $\begin{array}{c}\text { São Raimundo do Doca } \\
\text { Bezerra } \\
\end{array}$ & PM & 5.345 & 14,52 & $\mathrm{R} \$ \quad 7.209,00$ & 0,516 & $23,63 \%$ & $0,00 \%$ & 8,0 & $100,0 \%$ & $0,0 \%$ & & 3 & Não \\
\hline São Roberto & PM & 6.649 & 26,19 & $5.786,00$ & 0,516 & $42,04 \%$ & $0,00 \%$ & 10,0 & $100,0 \%$ & $0,0 \%$ & & 3 & Não \\
\hline São Vicente Ferrer & $\mathrm{PM}$ & 22.142 & 53,38 & $\mathrm{R} \$ \quad 6.288,00$ & 0,592 & $10,68 \%$ & $0,00 \%$ & 33,3 & $100,0 \%$ & $0,0 \%$ & & 3 & Não \\
\hline Satubinha & PM & 13.730 & 27,14 & $\mathrm{R} \$ \quad 4.767,00$ & 0,493 & $0,19 \%$ & $0,00 \%$ & 20,7 & $100,0 \%$ & $0,0 \%$ & & 3 & Não \\
\hline Senador Alexandre Costa & PM & 11.067 & 24,05 & $5.695,00$ & 0,538 & $2,27 \%$ & $0,00 \%$ & 16,7 & $100,0 \%$ & $0,0 \%$ & & 3 & Não \\
\hline Senador La Rocque & PM & 14.367 & 14,55 & $\mathrm{R} \$ 10.562,00$ & 0,602 & $23,96 \%$ & $0,00 \%$ & 21,6 & $100,0 \%$ & $0,0 \%$ & & 2 & Não \\
\hline Serrano do Maranhão & SAAE & 10.206 & 9,06 & $5.640,00$ & 0,519 & $0,43 \%$ & $0,00 \%$ & 15,4 & $100,0 \%$ & $0,0 \%$ & & 3 & Não \\
\hline Sítio Novo & SAAE & 18.001 & 5,46 & $7.622,00$ & 0,564 & $7,30 \%$ & $0,00 \%$ & 27,1 & $100,0 \%$ & $0,0 \%$ & & 3 & Não \\
\hline Sucupira do Norte & PM & 10.639 & 9,72 & $6.179,00$ & 0,579 & $1,80 \%$ & $0,00 \%$ & 16,0 & $100,0 \%$ & $0,0 \%$ & & 3 & Não \\
\hline Sucupira do Riachão & PM & 5.645 & 8,17 & $7.057,00$ & 0,568 & $1,08 \%$ & $0,00 \%$ & 8,5 & $100,0 \%$ & $0,0 \%$ & & 3 & Não \\
\hline
\end{tabular}




\begin{tabular}{|c|c|c|c|c|c|c|c|c|c|c|c|c|c|}
\hline \multirow[b]{2}{*}{ Município } & \multirow[b]{2}{*}{$\begin{array}{l}\text { Prestador de } \\
\text { Serviço de } \\
\text { Esgotamento } \\
\text { Sanitário }\end{array}$} & \multirow[b]{2}{*}{$\begin{array}{c}\text { População } \\
\text { Estimada } \\
2018 \\
\text { (IBGE,20 } \\
18 \text { ) }\end{array}$} & \multirow[b]{2}{*}{$\begin{array}{c}\text { Densida } \\
\text { de } \\
\text { Demogr } \\
\text { áfica } \\
\text { (IBGE,2 } \\
010)\end{array}$} & \multirow[b]{2}{*}{$\begin{array}{l}\text { PIB per capita } \\
\text { (IBGE,2010) }\end{array}$} & \multirow[b]{2}{*}{$\begin{array}{c}\text { IDHM } \\
\text { (PNUD, } \\
2010 \text { ) }\end{array}$} & \multirow[b]{2}{*}{$\begin{array}{c}\text { Índice de } \\
\text { Atendimento } \\
\text { por Solução } \\
\text { Individual } \\
\text { (ANA, 2017) } \\
\text { *Soluções a } \\
\text { nível } \\
\text { doméstico, } \\
\text { como valas } \\
\text { de } \\
\text { infiltração, } \\
\text { fossa negra e } \\
\text { fossa séptica }\end{array}$} & \multirow[b]{2}{*}{$\begin{array}{c}\text { Índice de } \\
\text { Atendimento } \\
\text { por Solução } \\
\text { Coletiva } \\
\text { (ANA, 2017; } \\
\text { SNIS, 2018) } \\
\text { *Soluções a } \\
\text { nível municipal } \\
\text { ou em } \\
\text { condomínios }\end{array}$} & \multirow[b]{2}{*}{$\begin{array}{c}\text { Vazão } \\
\text { estimada de } \\
\text { esgoto } \\
\text { doméstico } \\
\text { (L/s) } \\
(\sim 130 \mathrm{~L} / \mathrm{d} . \mathrm{ha} \\
\text { b) }\end{array}$} & \multicolumn{5}{|c|}{ Levantamento } \\
\hline & & & & & & & & & $\begin{array}{c}\text { Índice de } \\
\text { Atendimento } \\
\text { - Solução } \\
\text { Individual } \\
\text { *Soluções a } \\
\text { nível } \\
\text { doméstico, } \\
\text { como valas } \\
\text { de } \\
\text { infiltração, } \\
\text { fossa negra e } \\
\text { fossa séptica }\end{array}$ & $\begin{array}{c}\text { Índice de } \\
\text { Atendimento } \\
\text { - Solução } \\
\text { Coletiva } \\
\text { *Soluções a } \\
\text { nível } \\
\text { municipal ou } \\
\text { em } \\
\text { condomínios }\end{array}$ & $\begin{array}{l}\mathrm{N}^{o} \mathrm{de} \\
\text { ETEs }\end{array}$ & Grupo & $\begin{array}{l}\text { PMSB } \\
\text { aprovado }\end{array}$ \\
\hline Tasso Fragoso & PM & 8.459 & 1,78 & $\mathrm{R} \$ 58.404,00$ & 0,599 & $1,48 \%$ & $10,69 \%$ & 12,7 & $100,0 \%$ & $0,0 \%$ & & 2 & Não \\
\hline Timbiras & PM & 29.064 & 18,83 & $\mathrm{R} \$ \quad 4.849,00$ & 0,537 & $21,12 \%$ & $0,00 \%$ & 43,7 & $100,0 \%$ & $0,0 \%$ & & 3 & Não \\
\hline Timon & $\begin{array}{l}\text { Águas de } \\
\text { Timon }\end{array}$ & 167.973 & 89,18 & $9.617,00$ & 0,649 & $35,12 \%$ & $0,50 \%$ & 252,7 & $97,0 \%$ & $3,0 \%$ & 2 & 2 & $\operatorname{Sim}$ \\
\hline Trizidela do Vale & $\mathrm{PM}$ & 21.885 & 85,01 & $8.268,00$ & 0,606 & $16,21 \%$ & $0,00 \%$ & 32,9 & $100,0 \%$ & $0,0 \%$ & & 2 & Não \\
\hline Tufilândia & PM & 5.826 & 20,65 & $\mathrm{R} \$ \quad 6.920,00$ & 0,555 & $0,70 \%$ & $0,00 \%$ & 8,8 & $100,0 \%$ & $0,0 \%$ & & 3 & Não \\
\hline Tuntum & PM & 41.621 & 11,56 & $\mathrm{R} \$ \quad 6.739,00$ & 0,572 & $5,16 \%$ & $0,00 \%$ & 62,6 & $100,0 \%$ & $0,0 \%$ & & 3 & Não \\
\hline Turiaçu & PM & 35.497 & 13,16 & $\mathrm{R} \$ \quad 8.333,00$ & 0,561 & $7,57 \%$ & $0,00 \%$ & 53,4 & $100,0 \%$ & $0,0 \%$ & & 3 & Não \\
\hline Turilândia & PM & 25.365 & 15,11 & $5.974,00$ & 0,536 & $8,77 \%$ & $0,00 \%$ & 38,2 & $100,0 \%$ & $0,0 \%$ & & 3 & Não \\
\hline Tutóia & CAEMA/PM & 58.311 & 31,96 & $6.766,00$ & 0,561 & $5,02 \%$ & $0,00 \%$ & 87,7 & $98,0 \%$ & $2,0 \%$ & 1 & 3 & Não \\
\hline Urbano Santos & PM & 32.775 & 20,35 & $5.403,00$ & 0,588 & $22,59 \%$ & $0,00 \%$ & 49,3 & $100,0 \%$ & $0,0 \%$ & & 3 & Não \\
\hline
\end{tabular}




\begin{tabular}{|c|c|c|c|c|c|c|c|c|c|c|c|c|c|}
\hline \multirow[b]{2}{*}{ Município } & \multirow[b]{2}{*}{$\begin{array}{l}\text { Prestador de } \\
\text { Serviço de } \\
\text { Esgotamento } \\
\text { Sanitário }\end{array}$} & \multirow[b]{2}{*}{$\begin{array}{c}\text { População } \\
\text { Estimada } \\
2018 \\
\text { (IBGE,20 } \\
18 \text { ) }\end{array}$} & \multirow[b]{2}{*}{$\begin{array}{c}\text { Densida } \\
\text { de } \\
\text { Demogr } \\
\text { áfica } \\
\text { (IBGE,2 } \\
010)\end{array}$} & \multirow[b]{2}{*}{$\begin{array}{l}\text { PIB per capita } \\
\text { (IBGE,2010) }\end{array}$} & \multirow[b]{2}{*}{$\begin{array}{c}\text { IDHM } \\
\text { (PNUD, } \\
2010)\end{array}$} & \multirow[b]{2}{*}{$\begin{array}{c}\text { Índice de } \\
\text { Atendimento } \\
\text { por Solução } \\
\text { Individual } \\
\text { (ANA, 2017) } \\
\text { *Soluções a } \\
\text { nível } \\
\text { doméstico, } \\
\text { como valas } \\
\text { de } \\
\text { infiltração, } \\
\text { fossa negra e } \\
\text { fossa séptica }\end{array}$} & \multirow[b]{2}{*}{$\begin{array}{c}\text { Índice de } \\
\text { Atendimento } \\
\text { por Solução } \\
\text { Coletiva } \\
\text { (ANA, 2017; } \\
\text { SNIS, 2018) } \\
\text { *Soluções a } \\
\text { nível municipal } \\
\text { ou em } \\
\text { condomínios }\end{array}$} & \multirow[b]{2}{*}{$\begin{array}{c}\text { Vazão } \\
\text { estimada de } \\
\text { esgoto } \\
\text { doméstico } \\
\text { (L/s) } \\
(\sim 130 \mathrm{~L} / \mathrm{d} . h a \\
\text { b) }\end{array}$} & \multicolumn{5}{|c|}{ Levantamento } \\
\hline & & & & & & & & & $\begin{array}{c}\text { Índice de } \\
\text { Atendimento } \\
\text { - Solução } \\
\text { Individual } \\
\text { *Soluções a } \\
\text { nível } \\
\text { doméstico, } \\
\text { como valas } \\
\text { de } \\
\text { infiltração, } \\
\text { fossa negra e } \\
\text { fossa séptica }\end{array}$ & $\begin{array}{l}\text { Índice de } \\
\text { Atendimento } \\
\text { - Solução } \\
\text { Coletiva } \\
\text { *Soluções a } \\
\text { nível } \\
\text { municipal ou } \\
\text { em } \\
\text { condomínios }\end{array}$ & $\begin{array}{l}\mathrm{N}^{\circ} \text { de } \\
\text { ETEs }\end{array}$ & Grupo & $\begin{array}{l}\text { PMSB } \\
\text { aprovado }\end{array}$ \\
\hline Vargem Grande & CAEMA/PM & 55.841 & 25,24 & $\mathrm{R} \$ \quad 5.092,00$ & 0,542 & $21,47 \%$ & $0,00 \%$ & 84,0 & $98,0 \%$ & $2,0 \%$ & 1 & 3 & Não \\
\hline Viana & PM & 52.229 & 42,36 & $\mathrm{R} \$ \quad 7.803,00$ & 0,618 & $45,77 \%$ & $0,00 \%$ & 78,6 & $100,0 \%$ & $0,0 \%$ & & 2 & Não \\
\hline Vila Nova dos Martírios & $\mathrm{PM}$ & 13.183 & 9,47 & $\mathrm{R} \$ \quad 16.510,00$ & 0,581 & $0,52 \%$ & $50,00 \%$ & 19,8 & $100,0 \%$ & $0,0 \%$ & & 2 & Não \\
\hline Vitória do Mearim & PM & 32.664 & 43,56 & $8.772,00$ & 0,596 & $30,36 \%$ & $0,00 \%$ & 49,1 & $100,0 \%$ & $0,0 \%$ & & 2 & Não \\
\hline Vitorino Freire & PM & 31.525 & 24,26 & $6.932,00$ & 0,570 & $11,21 \%$ & $0,00 \%$ & 47,4 & $100,0 \%$ & $0,0 \%$ & & 3 & Não \\
\hline Zé Doca & PM & 51.471 & 20,77 & $\mathrm{R} \$ \quad 7.489,00$ & 0,595 & $10,48 \%$ & $0,00 \%$ & 77,4 & $100,0 \%$ & $0,0 \%$ & & 2 & Não \\
\hline
\end{tabular}




\section{APÊNDICE D}

Levantamento das ETEs do Estado

Fonte: Elaborado pela própria autora 


\begin{tabular}{|c|c|c|c|c|c|c|}
\hline $\mathbf{N}^{\mathbf{o}}$ & Município & ETE & $\begin{array}{c}\text { Porte do } \\
\text { sistema }\end{array}$ & Tipo & $\begin{array}{c}\text { Tipo de } \\
\text { tecnologia de } \\
\text { tratamento }\end{array}$ & Responsável \\
\hline 1 & $\begin{array}{l}\text { Alto do } \\
\text { Parnaíba }\end{array}$ & ETE 1 & $\begin{array}{l}\text { Pequeno } \\
\text { porte }\end{array}$ & Residencial & $\begin{array}{c}\text { Lagoa de } \\
\text { estabilização }\end{array}$ & Prefeitura \\
\hline 2 & $\begin{array}{l}\text { Alto do } \\
\text { Parnaíba }\end{array}$ & ETE 2 & $\begin{array}{l}\text { Pequeno } \\
\text { porte }\end{array}$ & Residencial & $\begin{array}{c}\text { Lagoa de } \\
\text { estabilização }\end{array}$ & Prefeitura \\
\hline 3 & Bacabal & ETE & $\begin{array}{l}\text { Pequeno } \\
\text { porte }\end{array}$ & Municipal & $\begin{array}{c}\text { Lagoa de } \\
\text { estabilização }\end{array}$ & SAAE \\
\hline 4 & Barreirinhas & $\begin{array}{c}\text { Barreirinha } \\
\mathrm{s}\end{array}$ & Médio porte & Municipal & $\begin{array}{c}\text { Lagoa de } \\
\text { estabilização }\end{array}$ & CAEMA \\
\hline 5 & Buriticupu & Eco Buriti & $\begin{array}{l}\text { Pequeno } \\
\text { porte }\end{array}$ & Residencial & UASB & CAEMA \\
\hline 6 & Carolina & COHAB & $\begin{array}{l}\text { Pequeno } \\
\text { porte }\end{array}$ & Municipal & Lodos ativados & SAAE \\
\hline 7 & Carolina & Brejinho & $\begin{array}{l}\text { Pequeno } \\
\text { porte }\end{array}$ & Municipal & Lodos ativados & SAAE \\
\hline 8 & Caxias & $\begin{array}{l}\text { ETE Vale } \\
\text { do Sol }\end{array}$ & $\begin{array}{l}\text { Pequeno } \\
\text { porte }\end{array}$ & Municipal & UASB & SAAE \\
\hline 9 & Caxias & $\begin{array}{c}\text { ETE Vila } \\
\text { Paraíso }\end{array}$ & $\begin{array}{l}\text { Pequeno } \\
\text { porte }\end{array}$ & Municipal & UASB & SAAE \\
\hline 10 & Caxias & $\begin{array}{l}\text { ETE Volta } \\
\text { Redonda }\end{array}$ & $\begin{array}{l}\text { Pequeno } \\
\text { porte }\end{array}$ & Municipal & $\begin{array}{c}\text { Lagoa de } \\
\text { estabilização }\end{array}$ & SAAE \\
\hline 11 & Chapadinha & Renascer & $\begin{array}{l}\text { Pequeno } \\
\text { porte }\end{array}$ & Residencial & UASB & CAEMA \\
\hline 12 & Coroatá & Coroatá & $\begin{array}{l}\text { Pequeno } \\
\text { porte }\end{array}$ & Residencial & UASB & CAEMA \\
\hline 13 & Estreito & $\begin{array}{l}\text { Newton } \\
\text { Coelho }\end{array}$ & $\begin{array}{l}\text { Pequeno } \\
\text { porte }\end{array}$ & Residencial & $\begin{array}{c}\text { Lagoa de } \\
\text { estabilização }\end{array}$ & SAAE \\
\hline 14 & $\begin{array}{l}\text { Itapecuru- } \\
\text { Mirim }\end{array}$ & $\begin{array}{c}\text { Isabel } \\
\text { Mendes }\end{array}$ & $\begin{array}{l}\text { Pequeno } \\
\text { porte }\end{array}$ & Residencial & UASB & CAEMA \\
\hline 15 & Imperatriz & Imperatriz & Grande porte & Municipal & $\begin{array}{c}\text { Lagoa de } \\
\text { estabilização }\end{array}$ & CAEMA \\
\hline 16 & Imperatriz & $\begin{array}{l}\text { Sebastião } \\
\text { Regis }\end{array}$ & $\begin{array}{l}\text { Pequeno } \\
\text { porte }\end{array}$ & Residencial & $\begin{array}{c}\text { Reator RAN + } \\
\text { Filtro } \\
\text { submerso } \\
\text { aerado (FSA) }\end{array}$ & CAEMA \\
\hline 17 & Imperatriz & $\begin{array}{l}\text { Itamar } \\
\text { Guará }\end{array}$ & $\begin{array}{l}\text { Pequeno } \\
\text { porte }\end{array}$ & Residencial & $\begin{array}{c}\text { Reator RAFA } \\
+ \text { Filtro } \\
\text { submerso } \\
\text { aerado (FSA) }\end{array}$ & CAEMA \\
\hline 18 & Imperatriz & $\begin{array}{l}\text { Teotônio } \\
\text { Vilela }\end{array}$ & $\begin{array}{l}\text { Pequeno } \\
\text { porte }\end{array}$ & Residencial & UASB & CAEMA \\
\hline
\end{tabular}




\begin{tabular}{|c|c|c|c|c|c|c|}
\hline $\mathbf{N}^{\mathbf{o}}$ & Município & ETE & $\begin{array}{c}\text { Porte do } \\
\text { sistema }\end{array}$ & Tipo & $\begin{array}{c}\text { Tipo de } \\
\text { tecnologia de } \\
\text { tratamento }\end{array}$ & Responsável \\
\hline 19 & $\begin{array}{l}\text { Miranda do } \\
\text { Norte }\end{array}$ & $\begin{array}{l}\text { Miranda do } \\
\text { Norte }\end{array}$ & $\begin{array}{l}\text { Pequeno } \\
\text { porte }\end{array}$ & Residencial & $\begin{array}{c}\text { Lagoa de } \\
\text { estabilização }\end{array}$ & CAEMA \\
\hline 20 & Parnarama & $\begin{array}{c}\text { ETE } \\
\text { Parnarama } \\
\end{array}$ & $\begin{array}{l}\text { Pequeno } \\
\text { porte }\end{array}$ & Municipal & $\begin{array}{c}\text { Lagoa de } \\
\text { estabilização }\end{array}$ & SAAE \\
\hline 21 & Paço do Lumiar & $\begin{array}{l}\text { Plaza das } \\
\text { flores }\end{array}$ & $\begin{array}{l}\text { Pequeno } \\
\text { porte }\end{array}$ & Residencial & $\begin{array}{c}\text { UASB + } \\
\text { FILTRO } \\
\text { AERADO + } \\
\text { DECANT. } \\
\text { SECUND. + } \\
\text { TQ DE } \\
\text { CONTATO }\end{array}$ & BRK \\
\hline 22 & Paço do Lumiar & $\begin{array}{c}\text { Novo } \\
\text { horizonte }\end{array}$ & $\begin{array}{l}\text { Pequeno } \\
\text { porte }\end{array}$ & Residencial & $\begin{array}{c}\text { UASB + } \\
\text { FILTRO } \\
\text { AERADO + } \\
\text { TQ. } \\
\text { CONTATO }\end{array}$ & BRK \\
\hline 23 & Paço do Lumiar & $\begin{array}{l}\text { Nova } \\
\text { aurora }\end{array}$ & $\begin{array}{l}\text { Pequeno } \\
\text { porte }\end{array}$ & Residencial & $\begin{array}{c}\text { UASB + } \\
\text { FILTRO } \\
\text { AERADO + } \\
\text { DECANT. } \\
\text { SECUND. + } \\
\text { TQ. } \\
\text { CONTATO }\end{array}$ & BRK \\
\hline 24 & Paço do Lumiar & $\begin{array}{c}\text { Jardim } \\
\text { primavera }\end{array}$ & $\begin{array}{l}\text { Pequeno } \\
\text { porte }\end{array}$ & Residencial & $\begin{array}{c}\text { UASB + } \\
\text { FILTRO } \\
\text { AERADO + } \\
\text { TQ. } \\
\text { CONTATO }\end{array}$ & BRK \\
\hline 25 & Paço do Lumiar & $\begin{array}{l}\text { Morada do } \\
\text { bosque }\end{array}$ & $\begin{array}{l}\text { Pequeno } \\
\text { porte }\end{array}$ & Residencial & $\begin{array}{c}\text { UASB + } \\
\text { FILTRO } \\
\text { AERADO + } \\
\text { TQ. } \\
\text { CONTATO }\end{array}$ & BRK \\
\hline 26 & Paço do Lumiar & Damha & $\begin{array}{l}\text { Pequeno } \\
\text { porte }\end{array}$ & Residencial & $\begin{array}{c}\text { LODO } \\
\text { ATIVADO + } \\
\text { DECANT. } \\
\text { SECUND }\end{array}$ & BRK \\
\hline 27 & Paço do Lumiar & $\begin{array}{l}\text { Pintangueir } \\
\text { as }\end{array}$ & $\begin{array}{l}\text { Pequeno } \\
\text { porte }\end{array}$ & Residencial & $\begin{array}{c}\text { UASB + } \\
\text { FILTRO } \\
\text { AERADO + } \\
\text { DECANT. } \\
\text { LAMELAR + } \\
\text { TQ. } \\
\text { CONTATO }\end{array}$ & BRK \\
\hline 28 & Paço do Lumiar & $\begin{array}{l}\text { Jardins } \\
\text { d'italia }^{\prime}\end{array}$ & $\begin{array}{l}\text { Pequeno } \\
\text { porte }\end{array}$ & Residencial & $\begin{array}{c}\text { TANQUE } \\
\text { SÉPTICO + }\end{array}$ & BRK \\
\hline
\end{tabular}




\begin{tabular}{|c|c|c|c|c|c|c|}
\hline $\mathbf{N}^{\mathbf{o}}$ & Município & ETE & $\begin{array}{l}\text { Porte do } \\
\text { sistema }\end{array}$ & Tipo & $\begin{array}{c}\text { Tipo de } \\
\text { tecnologia de } \\
\text { tratamento }\end{array}$ & Responsável \\
\hline & & & & & $\begin{array}{c}\text { FILTRO } \\
\text { ANAERÓBIO }\end{array}$ & \\
\hline 29 & Pinheiro & Coqueiros & $\begin{array}{l}\text { Pequeno } \\
\text { porte }\end{array}$ & Residencial & UASB + Filtro & CAEMA \\
\hline 30 & $\begin{array}{l}\text { São José de } \\
\text { Ribamar }\end{array}$ & Lima verde & $\begin{array}{c}\text { Pequeno } \\
\text { porte }\end{array}$ & Municipal & $\begin{array}{c}\text { UASB+FILTR } \\
\text { O AERADO + } \\
\text { DECANTA } \\
\text { SECUNDÁRI } \\
\text { O TQ } \\
\text { CONTATO }\end{array}$ & BRK \\
\hline 31 & $\begin{array}{l}\text { São José de } \\
\text { Ribamar }\end{array}$ & Nova terra & $\begin{array}{c}\text { Pequeno } \\
\text { porte }\end{array}$ & Residencial & $\begin{array}{c}\text { UASB + } \\
\text { FILTRO } \\
\text { AERADO + } \\
\text { TQ. } \\
\text { CONTATO }\end{array}$ & BRK \\
\hline 32 & $\begin{array}{l}\text { São José de } \\
\text { Ribamar }\end{array}$ & Turiúba & $\begin{array}{c}\text { Pequeno } \\
\text { porte }\end{array}$ & Residencial & $\begin{array}{c}\text { UASB + } \\
\text { FILTRO } \\
\text { AERADO + } \\
\text { TQ. } \\
\text { CONTATO }\end{array}$ & BRK \\
\hline 33 & $\begin{array}{l}\text { São José de } \\
\text { Ribamar }\end{array}$ & $\begin{array}{c}\text { Gran } \\
\text { village } \\
\text { araçagy }\end{array}$ & $\begin{array}{l}\text { Pequeno } \\
\text { porte }\end{array}$ & Residencial & $\begin{array}{c}\text { UASB + } \\
\text { FILTRO } \\
\text { AERADO }\end{array}$ & BRK \\
\hline 34 & $\begin{array}{l}\text { São José de } \\
\text { Ribamar }\end{array}$ & $\begin{array}{l}\text { Portal do } \\
\text { paço }\end{array}$ & $\begin{array}{l}\text { Pequeno } \\
\text { porte }\end{array}$ & Residencial & $\begin{array}{c}\text { UASB + } \\
\text { FILTRO } \\
\text { AERADO + } \\
\text { DECANT. } \\
\text { SECUND. TQ. } \\
\text { CONTATO + } \\
\text { TQ DE } \\
\text { CONTATO }\end{array}$ & BRK \\
\hline 35 & $\begin{array}{l}\text { São José de } \\
\text { Ribamar }\end{array}$ & Arvores & $\begin{array}{l}\text { Pequeno } \\
\text { porte }\end{array}$ & Residencial & $\begin{array}{c}\text { TANQUE } \\
\text { SÉPTICO + } \\
\text { FILTRO } \\
\text { ANAERÓBIO } \\
\text { + TQ DE } \\
\text { CONTATO }\end{array}$ & BRK \\
\hline 36 & $\begin{array}{l}\text { São José de } \\
\text { Ribamar }\end{array}$ & Paraty & $\begin{array}{l}\text { Pequeno } \\
\text { porte }\end{array}$ & Residencial & $\begin{array}{c}\text { LODO } \\
\text { ATIVADO + } \\
\text { AERAÇÃO } \\
\text { PROLONGAD } \\
\text { A }\end{array}$ & BRK \\
\hline 37 & $\begin{array}{l}\text { São José de } \\
\text { Ribamar }\end{array}$ & $\begin{array}{l}\text { Village dos } \\
\text { pássaros }\end{array}$ & $\begin{array}{l}\text { Pequeno } \\
\text { porte }\end{array}$ & Residencial & $\begin{array}{c}\text { UASB + } \\
\text { FILTRO } \\
\text { AERADO + } \\
\text { DECANT. } \\
\text { LAMELAR + }\end{array}$ & BRK \\
\hline
\end{tabular}




\begin{tabular}{|c|c|c|c|c|c|c|}
\hline $\mathbf{N}^{\mathbf{o}}$ & Município & ETE & $\begin{array}{c}\text { Porte do } \\
\text { sistema }\end{array}$ & Tipo & $\begin{array}{c}\text { Tipo de } \\
\text { tecnologia de } \\
\text { tratamento }\end{array}$ & Responsável \\
\hline & & & & & $\begin{array}{c}\text { TQ. } \\
\text { CONTATO }\end{array}$ & \\
\hline 38 & $\begin{array}{l}\text { São José de } \\
\text { Ribamar }\end{array}$ & $\begin{array}{l}\text { São josé } \\
\text { i,ii, iii e iv - } \\
\text { tropical }\end{array}$ & $\begin{array}{l}\text { Pequeno } \\
\text { porte }\end{array}$ & Residencial & $\begin{array}{c}\text { TANQUE } \\
\text { SÉPTICO + } \\
\text { FILTRO } \\
\text { ANAERÓBIO }\end{array}$ & BRK \\
\hline 39 & $\begin{array}{l}\text { São José de } \\
\text { Ribamar }\end{array}$ & $\begin{array}{l}\text { Riviera } \\
\text { cohatrac }\end{array}$ & $\begin{array}{l}\text { Pequeno } \\
\text { porte }\end{array}$ & Residencial & $\begin{array}{c}\text { UASB + } \\
\text { FILTRO } \\
\text { AERADO + } \\
\text { DECANT. } \\
\text { SECUND. }\end{array}$ & BRK \\
\hline 40 & $\begin{array}{l}\text { São José de } \\
\text { Ribamar }\end{array}$ & $\begin{array}{l}\text { Bonavita } \\
\text { club e } \\
\text { prime }\end{array}$ & $\begin{array}{l}\text { Pequeno } \\
\text { porte }\end{array}$ & Residencial & $\begin{array}{c}\text { DECANTAÇÃ } \\
\text { O PRIMÁRIA } \\
+ \text { LODO } \\
\text { ATIVADO } \\
\text { C/LEITO } \\
\text { MÓVEL + } \\
\text { DECANT. } \\
\text { SECUND. } \\
\text { LAMELAR + } \\
\text { TQ. } \\
\text { CONTATO }\end{array}$ & BRK \\
\hline 41 & $\begin{array}{l}\text { São José de } \\
\text { Ribamar }\end{array}$ & Bella vista & $\begin{array}{l}\text { Pequeno } \\
\text { porte }\end{array}$ & Residencial & $\begin{array}{c}\text { DECANTAD } \\
\text { OR } \\
\text { PRIMÁRIO + } \\
\text { LODO } \\
\text { ATIVADO C/ } \\
\text { LEITO } \\
\text { MÓVEL + } \\
\text { DECANT. } \\
\text { SECUNDÁRI } \\
\text { O LAMELAR } \\
\text { + TQ. DE } \\
\text { CONTATO }\end{array}$ & BRK \\
\hline 42 & $\begin{array}{l}\text { São José de } \\
\text { Ribamar }\end{array}$ & $\begin{array}{l}\text { Recanto } \\
\text { verde }\end{array}$ & $\begin{array}{l}\text { Pequeno } \\
\text { porte }\end{array}$ & Residencial & $\begin{array}{c}\text { UASB + } \\
\text { FILTRO } \\
\text { AERADO + } \\
\text { DECANT. } \\
\text { SECUND. + } \\
\text { TQ DE } \\
\text { CONTATO }\end{array}$ & BRK \\
\hline 43 & $\begin{array}{l}\text { São José de } \\
\text { Ribamar }\end{array}$ & $\begin{array}{l}\text { Residencial } \\
\text { turu }\end{array}$ & $\begin{array}{l}\text { Pequeno } \\
\text { porte }\end{array}$ & Residencial & $\begin{array}{c}\text { UASB + } \\
\text { FILTRO } \\
\text { AERADO + } \\
\text { DECANT. } \\
\text { LAMELAR + }\end{array}$ & BRK \\
\hline
\end{tabular}




\begin{tabular}{|c|c|c|c|c|c|c|}
\hline $\mathbf{N}^{\mathbf{o}}$ & Município & ETE & $\begin{array}{l}\text { Porte do } \\
\text { sistema }\end{array}$ & Tipo & $\begin{array}{c}\text { Tipo de } \\
\text { tecnologia de } \\
\text { tratamento }\end{array}$ & Responsável \\
\hline & & & & & $\begin{array}{c}\text { TQ. } \\
\text { CONTATO }\end{array}$ & \\
\hline 44 & $\begin{array}{l}\text { São José de } \\
\text { Ribamar }\end{array}$ & Miritiua & $\begin{array}{l}\text { Pequeno } \\
\text { porte }\end{array}$ & Residencial & $\begin{array}{c}\text { UASB + Filtro } \\
\text { Aerado }\end{array}$ & BRK \\
\hline 45 & $\begin{array}{l}\text { São José de } \\
\text { Ribamar }\end{array}$ & $\begin{array}{l}\text { Bela cintra } \\
\text { Prime }\end{array}$ & $\begin{array}{l}\text { Pequeno } \\
\text { porte }\end{array}$ & Residencial & $\begin{array}{c}\text { UASB + } \\
\text { FILTRO } \\
\text { AERADO + } \\
\text { DECANT. } \\
\text { SECUND. }\end{array}$ & BRK \\
\hline 46 & $\begin{array}{l}\text { São José de } \\
\text { Ribamar }\end{array}$ & $\begin{array}{l}\text { Dunas do } \\
\text { sol }\end{array}$ & $\begin{array}{l}\text { Pequeno } \\
\text { porte }\end{array}$ & Residencial & $\begin{array}{c}\text { UASB + } \\
\text { FILTRO } \\
\text { AERADO + } \\
\text { DECANT. } \\
\text { SECUND. TQ. } \\
\text { CONTATO }\end{array}$ & BRK \\
\hline 47 & $\begin{array}{l}\text { São José de } \\
\text { Ribamar }\end{array}$ & $\begin{array}{l}\text { Mirante do } \\
\quad \text { rio }\end{array}$ & $\begin{array}{l}\text { Pequeno } \\
\text { porte }\end{array}$ & Residencial & $\begin{array}{c}\text { UASB }+ \\
\text { FILTRO } \\
\text { AERADO + } \\
\text { TQ. } \\
\text { CONTATO }\end{array}$ & BRK \\
\hline 48 & $\begin{array}{l}\text { São José de } \\
\text { Ribamar }\end{array}$ & Tracoá & $\begin{array}{l}\text { Pequeno } \\
\text { porte }\end{array}$ & Residencial & $\begin{array}{c}\text { UASB + } \\
\text { FILTRO } \\
\text { AERADO + } \\
\text { DECANT. } \\
\text { SECUND. }\end{array}$ & BRK \\
\hline 55 & São Luís & $\begin{array}{l}\text { Amendoeir } \\
\mathrm{a}\end{array}$ & $\begin{array}{l}\text { Pequeno } \\
\text { porte }\end{array}$ & Residencial & UASB & CAEMA \\
\hline 49 & São Luís & Anil & Médio porte & Municipal & $\begin{array}{c}\text { UASB + } \\
\text { DESONIZAÇ } \\
\tilde{A} O\end{array}$ & CAEMA \\
\hline 52 & São Luís & Bacanga & $\begin{array}{l}\text { Pequeno } \\
\text { porte }\end{array}$ & Municipal & $\begin{array}{c}\text { UASB + } \\
\text { DESONIZAÇ } \\
\tilde{A} O\end{array}$ & CAEMA \\
\hline 53 & São Luís & Brasil & $\begin{array}{l}\text { Pequeno } \\
\text { porte }\end{array}$ & Residencial & UASB & CAEMA \\
\hline 63 & São Luís & Gaivota & $\begin{array}{l}\text { Pequeno } \\
\text { porte }\end{array}$ & Residencial & $\begin{array}{c}\text { Lagoa de } \\
\text { estabilização }\end{array}$ & CAEMA \\
\hline 50 & São Luís & Jaracaty & Médio porte & Municipal & $\begin{array}{c}\text { UASB + } \\
\text { DESONIZAÇ } \\
\tilde{\text { AOO }}\end{array}$ & CAEMA \\
\hline 59 & São Luís & Jasmins & $\begin{array}{l}\text { Pequeno } \\
\text { porte }\end{array}$ & Residencial & UASB & CAEMA \\
\hline 60 & São Luís & $\begin{array}{c}\text { Jomar } \\
\text { Moraes }\end{array}$ & $\begin{array}{l}\text { Pequeno } \\
\text { porte }\end{array}$ & Residencial & UASB & CAEMA \\
\hline
\end{tabular}




\begin{tabular}{|c|c|c|c|c|c|c|}
\hline $\mathbf{N}^{\mathbf{o}}$ & Município & ETE & $\begin{array}{c}\text { Porte do } \\
\text { sistema }\end{array}$ & Tipo & $\begin{array}{c}\text { Tipo de } \\
\text { tecnologia de } \\
\text { tratamento }\end{array}$ & Responsável \\
\hline 58 & São Luís & $\begin{array}{c}\text { Luiz } \\
\text { Bacelar }\end{array}$ & $\begin{array}{l}\text { Pequeno } \\
\text { porte }\end{array}$ & Residencial & UASB & CAEMA \\
\hline 61 & São Luís & $\begin{array}{l}\text { Morado do } \\
\text { Sol }\end{array}$ & $\begin{array}{l}\text { Pequeno } \\
\text { porte }\end{array}$ & Residencial & UASB & CAEMA \\
\hline 56 & São Luís & Piancó & $\begin{array}{l}\text { Pequeno } \\
\text { porte }\end{array}$ & Residencial & UASB & CAEMA \\
\hline 54 & São Luís & Ribeira & $\begin{array}{l}\text { Pequeno } \\
\text { porte }\end{array}$ & Residencial & UASB & CAEMA \\
\hline 62 & São Luís & $\begin{array}{c}\text { São } \\
\text { Jerônimo }\end{array}$ & $\begin{array}{l}\text { Pequeno } \\
\text { porte }\end{array}$ & Residencial & UASB & CAEMA \\
\hline 64 & São Luís & Tajaçoaba & $\begin{array}{l}\text { Pequeno } \\
\text { porte }\end{array}$ & Residencial & UASB & CAEMA \\
\hline 57 & São Luís & $\begin{array}{c}\text { Vila } \\
\text { Maranhão }\end{array}$ & $\begin{array}{l}\text { Pequeno } \\
\text { porte }\end{array}$ & Residencial & UASB & CAEMA \\
\hline 51 & São Luís & Vinhais & Médio porte & Municipal & $\begin{array}{c}\text { UASB + } \\
\text { DESONIZAÇ } \\
\tilde{A O O}\end{array}$ & CAEMA \\
\hline 65 & Timon & $\begin{array}{l}\text { Miguel } \\
\text { Arraes }\end{array}$ & $\begin{array}{l}\text { Pequeno } \\
\text { porte }\end{array}$ & Residencial & UASB & $\begin{array}{l}\text { Águas de } \\
\text { Timon }\end{array}$ \\
\hline 66 & Timon & $\begin{array}{l}\text { Lourival } \\
\text { Almeida }\end{array}$ & $\begin{array}{l}\text { Pequeno } \\
\text { porte }\end{array}$ & Residencial & UASB & $\begin{array}{c}\text { Águas de } \\
\text { Timon }\end{array}$ \\
\hline 67 & Tutoia & Tutoia & $\begin{array}{l}\text { Pequeno } \\
\text { porte }\end{array}$ & Residencial & UASB & CAEMA \\
\hline 68 & Vargem Grande & $\begin{array}{l}\text { Vargem } \\
\text { Grande }\end{array}$ & $\begin{array}{l}\text { Pequeno } \\
\text { porte }\end{array}$ & Residencial & UASB & CAEMA \\
\hline
\end{tabular}




\section{ANEXO I}

Levantamento dos processos de tratamento de esgoto doméstico no Brasil Fonte: ANA, 2017, p.33. 
FAIXAS DE REMOÇÃO DE DBO DOS PRINCIPAIS PROCESSOS DE TRATAMENTO NO BRASIL PRINCIPAIS

PROCESSOS DE

TRATAMENTO NO

POPULAÇÃO EFICIÊNCIA

BRASIL

\section{SIGLA EQUIVALENTE MÉDIA}

(em mil hab.)
$(\%)$
$\mathbf{N}^{\mathbf{0}}$

UNIDADES

\begin{tabular}{|c|c|c|c|c|c|}
\hline & PRIMÁRIO & $\operatorname{Pr}$ & $7.947,60$ & $35 \%$ & 21 \\
\hline & FOSSA FILTRO/FOSSA & & & & \\
\hline & SÉPTICA + FILTRO & FosFil/FosSép + & & & \\
\hline & AERÓBIO/TANQUE & FilAer/TqImh+F & 340,1 & $49 \%$ & 215 \\
\hline \multirow[t]{4}{*}{ até $60 \%$} & IMHOFF + FILTRO & ilB & & & \\
\hline & BIOLÓGICO & & & & \\
\hline & FOSSA & & & & \\
\hline & SÉPTICA/TANQUE & FosSép/TqImh & 49,2 & $51 \%$ & 23 \\
\hline
\end{tabular}

SUBTOTAL

259

FOSSA FILTRO/(FOSSA

SÉPTICA + FILTRO FosFil/(FosSép+

BIOLÓGICO) + FilB)+DispS/Su

$6,4 \quad 66 \%$

10

DISPOSIÇÃO NO

$\mathrm{m}$

SOLO/SUMIDOURO

\begin{tabular}{ccccc}
\hline $\begin{array}{c}\text { REATOR ANAERÓBIO } \\
+ \text { LODOS ATIVADOS }\end{array}$ & RtrAn+LodAt & 26,3 & $80 \%$ & 2 \\
\hline LAGOA ANAERÓBIA & LagAn & 812,8 & $68 \%$ & 68
\end{tabular}

PRIMÁRIO COM

FÍSICO QUÍMICO

$60 \%$ a $80 \%$

(FILTRO

AERÓBIO/DECANTAÇ

PrFisQ(FilAer/

$\mathrm{Dec} / \mathrm{Cept} / \mathrm{Flt}$ )

$1.902,50$

$68 \%$

13

ÃO/CEPT/FLOTAÇÃO)

\begin{tabular}{ccccc}
\hline REATOR ANAERÓBIO & RtrAn & $3.876,50$ & $69 \%$ & 328 \\
\hline $\begin{array}{c}\text { REATOR ANAERÓBIO } \\
+ \text { DECANTADOR }\end{array}$ & RtrAn+Dec & 226,7 & $72 \%$ & 16
\end{tabular}

TECANTADOR

LODOS ATIVADOS

MEIO FIXO (FILTRO LodAtMF(FilB)

323,1

$73 \%$

22

BIOLÓGICO)

REATOR ANAERÓBIO

+ FILTRO BIOLÓGICO

RtrAn+FilB

$1.300,00$

$75 \%$

177 
FAIXAS DE REMOÇÃO DE DBO DOS PRINCIPAIS PROCESSOS DE TRATAMENTO NO BRASIL PRINCIPAIS

PROCESSOS DE

TRATAMENTO NO

SIGLA EQUIVALENTE MÉDIA

BRASIL

(em mil hab.)

(\%)

UNIDADES

LAGOA

FACULTATIVA

LagFac

$1.421,00$

$76 \%$

203

LAGOA ANAERÓBIA +

LAGOA

$\operatorname{LagAn+\operatorname {LagFac}}$

$5.533,80$

$77 \%$

364

FACULTATIVA

REATOR ANAERÓBIO

+ DISPOSIÇÃO NO

RtrAn+DispS

183,3

$77 \%$

16

SOLO

\begin{tabular}{c}
\hline REATOR ANAERÓBIO \\
+ FILTRO AERÓBIO \\
\hline REATOR ANAERÓBIO \\
+ LAGOA
\end{tabular}

ANAERÓBIA/FACULT

ATIVA/DE

RtrAn+FilAer

635,8

$77 \%$

64

MATURAÇÃO

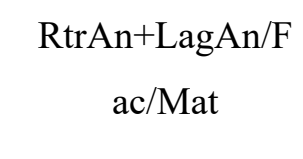

$3.023,50$

$78 \%$

145

\begin{tabular}{|c|c|c|c|c|}
\hline \multicolumn{3}{|c|}{ SUBTOTAL } & \multicolumn{2}{|r|}{1.428} \\
\hline LAGOA AERADA & LagArd & 743,6 & $80 \%$ & 42 \\
\hline $\begin{array}{c}\text { REATOR ANAERÓBIO } \\
+ \text { FILTRO AERÓBIO + } \\
\text { DECANTADOR }\end{array}$ & $\begin{array}{c}\text { RtrAn+FilAer }+ \\
\text { Dec }\end{array}$ & $4.436,90$ & $80 \%$ & 121 \\
\hline $\begin{array}{l}\text { REATOR ANAERÓBIO } \\
+ \text { FILTRO BIOLÓGICO } \\
\text { + DISPOSIÇÃO NO } \\
\text { SOLO }\end{array}$ & $\begin{array}{c}\text { RtrAn+FilB+Di } \\
\text { spS }\end{array}$ & 70,6 & $80 \%$ & 15 \\
\hline $\begin{array}{l}\text { REATOR ANAERÓBIO } \\
+ \text { FILTRO BIOLÓGICO } \\
+ \text { FILTRO AERÓBIO + } \\
\text { DECANTADOR }\end{array}$ & $\begin{array}{c}\text { RtrAn+FilB+Fil } \\
\text { Aer+Dec }\end{array}$ & 76,5 & $80 \%$ & 10 \\
\hline $\begin{array}{c}\text { LODOS ATIVADOS DE } \\
\text { AERAÇÃO } \\
\text { PROLONGADA }\end{array}$ & LodAtAerPln & $4.479,00$ & $88 \%$ & 91 \\
\hline
\end{tabular}


FAIXAS DE REMOÇÃO DE DBO DOS PRINCIPAIS PROCESSOS DE TRATAMENTO NO BRASIL PRINCIPAIS

PROCESSOS DE

TRATAMENTO NO

SIGLA EQUIVALENTE MÉDIA

BRASIL

POPULAÇÃO EFICIÊNCIA

(em mil hab.)
(\%)

$\mathbf{N}^{\mathbf{0}}$

UNIDADES

\section{LAGOA ANAERÓBIA + \\ LAGOA}

FACULTATIVA +

LAGOA DE

$\operatorname{LagAn}+\operatorname{LagFac}$

+ LagMat

$1.930,40$

$81 \%$

134

MATURAÇÃO

LAGOA

FACULTATIVA +

LAGOA DE

LagFac+LagMat

$1.212,50$

$81 \%$

119

MATURAÇÃO

LAGOA AERADA +

LAGOA DE

$>80 \%$

DECANTAÇÃO/FACUL

LagArd+LagDe

TATIVA/MATURAÇÃO

REATOR ANAERÓBIO

+ LAGOA AERADA

RtrAn+LagArd

611,2

$83 \%$

12

LODOS ATIVADOS

(CONVENCIONAL/DEE

LodAt(cnv/DpS

$2.349,00$

$82 \%$

64

P SHAFT)

REATOR ANAERÓBIO

+ LAGOA AERADA +

LAGOA

RtrAn+LagArd+

LagFac/Mat

322,9

$85 \%$

7

FACULTATIVA/MATU

RAÇÃO

REATOR ANAERÓBIO

+ LODOS ATIVADOS

RtrAn+LodAt

$3.964,80$

$86 \%$

90

LAGOA AERADA +

LAGOA

FACULTATIVA +

LagArd+LagFac

+ LagMat

658,2

$87 \%$

14

LAGOA DE

MATURAÇÃO 
FAIXAS DE REMOÇÃO DE DBO DOS PRINCIPAIS PROCESSOS DE TRATAMENTO NO BRASIL PRINCIPAIS

PROCESSOS DE

TRATAMENTO NO

SIGLA EQUIVALENTE MÉDIA

BRASIL

(em mil hab.)

(\%)

UNIDADES

REATOR ANAERÓBIO

+ LODOS ATIVADOS RtrAn+LodAtA

DE AERAÇÃO

53,4

$88 \%$

4

PROLONGADA

REATOR ANAERÓBIO

+ LAGOA RtrAn+LagFac+

FACULTATIVA +

DispS

226,7

$89 \%$

6

DISPOSIÇÃO NO SOLO

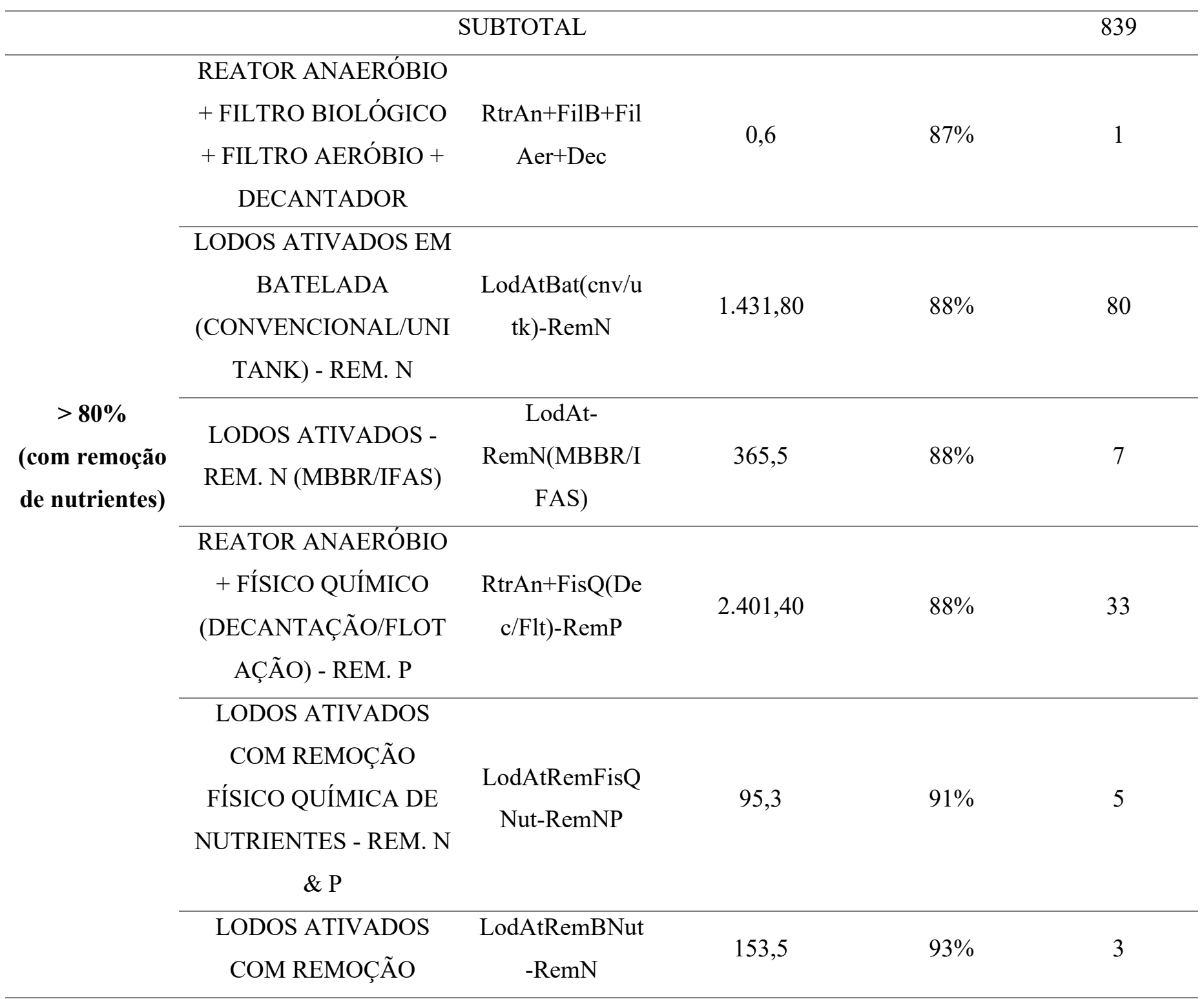


FAIXAS DE REMOÇÃO DE DBO DOS PRINCIPAIS PROCESSOS DE TRATAMENTO NO BRASIL PRINCIPAIS

$\begin{array}{ccccc}\text { PROCESSOS DE } & \text { POPULAÇÃO } & \text { EFICIÊNCIA } & \mathbf{N}^{\mathbf{2}} \\ \text { TRATAMENTO NO } & \text { SIGLA } & \text { EQUIVALENTE } & \text { MÉDIA } & \text { UNIDADES } \\ \text { BRASIL } & & (\text { em mil hab.) } & (\%) & \end{array}$

BIOLÓGICA DE

NUTRIENTES - REM. N

$>\mathbf{8 0} \%$ LODOS ATIVADOS

\begin{tabular}{ccccc} 
(com remoção & COM REMOÇÃO & LodAtRemBNut & 46,6 & 2 \\
de nutrientes) & BIOLÓGICA DE & -RemNP & $95 \%$ & \\
& NUTRIENTES - REM. N & & & 131 \\
\hline & SUBTOTAL & TOTAL & $\mathbf{2 . 6 5 7}$
\end{tabular}

